RAQUEL OLIMPIA PELÁEZ OCAMPO ALMEIDA

INDICADORES DA QUALIDADE DO SUBSTRATO PARA MONITORAMENTO DE ÁREAS REVEGETADAS: ESTUDO DIRIGIDO À MINERAÇÃO DE AREIA

Tese apresentada à Escola Politécnica da Universidade de São Paulo para a obtenção do Título de Doutor em Engenharia.

São Paulo 
RAQUEL OLIMPIA PELÁEZ OCAMPO ALMEIDA

INDICADORES DA QUALIDADE DO SUBSTRATO PARA MONITORAMENTO DE ÁREAS REVEGETADAS: ESTUDO DIRIGIDO À MINERAÇÃO DE AREIA

Tese apresentada à Escola Politécnica da Universidade de São Paulo para a obtenção do Título de Doutor em Engenharia

Área de Concentração:

Engenharia Mineral.

Orientador:

Prof. Dr. Luis Enrique Sánchez

São Paulo 


\section{FICHA CATALOGRAFICA}

Almeida, Raquel Olimpia Peláez Ocampo

Indicadores da qualidade do substrato para monitoramento de áreas revegetadas: estudo dirigido à mineração de areia / R.O.P.O. Almeida. -- São Paulo, 2010.

p. 222

Tese (Doutorado) - Escola Politécnica da Universidade de São Paulo. Departamento de Engenharia de Minas e de Petróleo.

1. Revegetação 2. Monitoramento ambiental (Metodologia) 3. Reabilitação de áreas degradadas 4. Estudo de caso l. Universidade de São Paulo. Escola Politécnica. Departamento de Engenharia de Minas e de Petróleo II. t. 
A Amilton por acreditar siempre......

A Miguel e a Rafael para que no dejen de acreditar..... 
Quién? si no......

\section{La Pachamama.}

Mi grano de arena en reciprocidad a ti. 


\section{AGRADECIMENTOS}

Ao meu orientador Professor Doutor Luis Enrique Sánchez por seus conselhos e ensinamentos e pela confiança depositada.

À FAPESP por financiar a pesquisa e viabilizá-la.

Ao programa CAPES pelo apoio financeiro com a bolsa de estudo.

À Mineração Descalvado por permitirme o acesso às áreas de estudo, em especial ao Engenheiro Luiz Veloza e ao amigo Engenheiro Fábio pela disposição e acompanhamento do trabalho.

À Universidade de São Paulo e ao Departamento de Engenharia de Minas pela oportunidade de aprimoramento como pós-graduanda.

Ao Professor Doutor Rodrigo Corrêa por seus esclarecimentos e sugestões na criteriosa revisão do texto de qualificação. Grata por me transmitir a segurança de estar no caminho certo.

Aos membros da Banca de Qualificação Doutora Elvira Gabriela Dias, Doutor Omar Yasbek e o Professor Doutor Wilson Iramina, por suas valiosas sugestões e observações para dar continuidade ao trabalho.

Ao Professor Doutor Álvaro de Almeida Chefe do Depto de Solos da ESALQ pelos ensinamentos e sugestões fundamentais.

Aos Professores Doutores Ricardo Rodrigues Ribeiro e Sergius Gandolfi do Laboratório de Ecologia e Restauração Florestal da ESALQ pelo apoio na condução do experimento piloto da pesquisa.

Ao Professor Doutor Tanaka e às graduandas Bety e Yurie do Centro de Estatística Aplicada da USP pelo trabalho detalhado com a análise dos dados.

Ao Professor Doutor Arthur Pinto Chavez por suas sugestões e correção do texto.

Aos amigos Martha e Ronaldo pela hospitalidade em Piracicaba e principalmente por me brindar seu precioso tempo para compartir seus conhecimentos 
À amiga Cleusa da Empresa Global que me acolheu em Descalvado e de quem recebi todo o apoio logístico e auxílio para as atividades de campo.

Ao Senhor Antônio por sua ajuda insubstituível no reconhecimento de espécies e ao José (Zé) por ser o único a não desistir no duro trabalho nas trincheiras

Ao pessoal do Laboratório de Solos de IPT e do Laboratório de Solos da Engenharia Civil da Poli que me abriram as portas, em especial ao Técnico Antônio por todo o auxílio nas análises laboratoriais.

Ao Professor Doutor Paulo Takeo Sano e aos pós-graduandos Matheus e Herbert do Laboratório de Sistemática Vegetal no Departamento de Botânica pela pronta disposição para a identificação das amostras de plantas.

Aos membros da Apemi e em especial ao Engenheiro Ayrton Sintoni, que continuam me mantendo ligada à problemática da mineração.

À Ana Claudia pelas horas de conversa e amizade concedida, à Cristina da Bibilioteca da Engenharia de Minas e de Petróleo pelo apoio e à Isabel por seu auxílio na confeção das figuras.

Ao irmão Adalberto na revisão do texto ("gracias por la ayuda").

Aos meus filhos Miguel e Rafael pela compreensão e sintonia e aos meus pais pelas suas orações.

$E$, especialmente, com amor a Amilton por seu constante incentivo, e pela sua presença transparente na realização desta pesquisa, ..... nosso norte continua.

Grata a todos aqueles que, de alguma forma, contribuíram para a realização deste trabalho. 


\section{RESUMO}

A mineração promove alterações significativas nos atributos do solo. Freqüentemente o substrato, proveniente de materiais estéreis do processo minerador, serve como meio de crescimento da vegetação das áreas em recuperação ambiental. Um procedimento para monitoramento da qualidade do substrato dessas áreas foi desenvolvido e testado. Os estudos foram conduzidos em uma mina de areia industrial situada no interior do Estado de São Paulo que apresenta cronosseqüência de medidas de restabelecimento de vegetação nativa em bacias de disposição de rejeitos de tratamento de minério, permitindo a simulação do monitoramento por um período de 14 anos. Foram analisadas as mudanças das características físico-químicas do substrato em conjunto com as mudanças na vegetação. Como resultado, verificou-se uma evolução positiva na qualidade do substrato que acompanha o desenvolvimento das espécies implantadas e conclui-se que as variáveis estudadas têm plena possibilidade de atuarem como indicadoras de desempenho da revegetação. Deste conjunto de variáveis, a densidade de solo, os teores de matéria orgânica e fósforo e o pH são os indicadores mais apropriados para avaliar o estado da revegetação, especificamente para as condições do ambiente das bacias de rejeito estudado. As áreas avaliadas encontram-se estabilizadas e contêm uma comunidade vegetal já formada. Contudo, a compactação do substrato, os baixos teores de matéria orgânica e o crescimento invasivo de Brachiaria decumbens (capim braquiária) foram identificados como fatores adversos que dificultam uma melhoria mais contundente na comunidade estabelecida. Concluiu-se que o método proposto constitui um instrumento prático para se obter parâmetros numéricos que permitam uma avaliação quantitativa e objetiva das áreas revegetadas e dos resultados das medidas de recuperação ambiental. Os indicadores podem ser utilizados em conjunto com parâmetros específicos que descrevam o estado da comunidade vegetal. Adicionalmente, podem ter aplicação em minerações de outros bens minerais, particularmente no caso de recuperação ambiental de bacias de disposição de rejeitos.

Palavras-chave: Recuperação, restauração ecológica, indicadores ambientais, revegetação; monitoramento, áreas mineradas. 


\begin{abstract}
Mining is an agent of significant changes in soil properties. Successful land rehabilitation depends on restoring those characteristics in natural soils or establishing a suitable substratum for plant growth using available materials such as waste rock or mineral tailings. A process for monitoring the quality of the substratum in mine-affected areas was developed and tested. The study was carried out at an industrial sand mine located in São Paulo State, Brazil. Different plots situated in a tailings pond were restored with native species by the company for the past 14 years, allowing for $10+$ years of simulated monitoring. Soil samples were collected to measure a series of physical and chemical substratum properties. Indicators of vegetation development were collected in each plot.. As a result, a positive quality evolution of the substratum is observed simultaneously with the development of planted trees. In conclusion it was verified that observed substratum variables have ample possibilities to be suitable as revegetation performing indicators. From all substratum variables studied, soil density, organic matter, $\mathrm{P}$ contents and $\mathrm{pH}$ are the most appropriated indicators, specifically in the environmental conditions of the tailings pond studied. All evaluated areas feature a well established vegetal community. However substratum compaction, low contents of organic matter and intense weed growing (Brachiaria decumbens) were identified as limitative. The proposed method sets up a practical instrument to obtain quantitative parameters that allow for an objective assessment of revegetated areas and environmental rehabilitation actions. The indicators may be applied to other types of mines, specifically in case of tailing disposal sites.
\end{abstract}

Key words: mine rehabilitation, ecological restoration, environmental indicators, revegetation; monitoring, mined areas. 


\section{LISTA DE FIGURAS}

Figura 1 - Localização da Mineração Descalvado. ......................................... $\quad 70$

Figura 2 - Balanço hídrico mensal para a região de Descalvado. …………..... 72

Figura 3 - Mapa da Mineração Descalvado destacando a antiga bacia de disposição de rejeitos e as áreas de estudo $A 1, A 2, A 3, A 4$, a5 e A6.

Figura 4 - Áreas revegetadas na bacia com a localização dos pontos de abertura das trincheiras para amostragem.

Figura 5 - Curvas granulométricas da fração areia, silte e argila, em diferentes profundidades da área A1.

Figura 6 - Resultados médios de densidade de solo e porosidade na camada superficial $(0-20 \mathrm{~cm})$ e na mais profunda $(80-100 \mathrm{~cm}) . . .129$

Figura 7 - Gráfico de dispersão CTC x MO na camada superficial $(0-20 \mathrm{~cm}) . \quad 143$

Figura 8 - Médias de altura e circunferência à altura do peito (CAP) das três espécies arbóreas mais freqüentes nas áreas revegetadas.

Figura 9 - Densidade de solo (Ds) e teor de matéria orgânica (MO) na camada superficial das áreas revegetadas e da mata nativa.

Figura 10 - Perfis médios de matéria orgânica $\left(\mathrm{mmolc} \cdot \mathrm{dm}^{-3}\right)$. 156

Figura 11 - Perfis médios da soma de bases $\left(\mathrm{mmolc} . \mathrm{dm}^{-3}\right)$. 156 


\section{LISTA DE TABELAS}

Tabela 1 - Influência das frações areia, silte e argila no comportamento do solo.

Tabela 2 - Valores de pH de amostras dos diferentes substratos e solos.

Tabela 3 - Teor de matéria orgânica de diferentes fontes.

Tabela 4 - Características das áreas de estudo e localização (UTM) de cada trincheira de amostragem.

Tabela 5 - Características visuais da vegetação e do substrato coletadas nas áreas de estudo.

Tabela 6 - Granulometria e Dp média por camadas observadas.

Tabela 7 - Granulometria e Dp média $\left(\mathrm{Mg}^{\mathrm{m}} \mathrm{m}^{-3}\right)$ por área de estudo.

Tabela 8 - Resultados médios de Ds (Mg. $\left.\mathrm{m}^{-3}\right)$ nas áreas de estudo.

Tabela 9 - Intervalos de confiança de Bonferroni para a variável Ds nas diferentes profundidades.

Tabela 10 - Intervalos de confiança de Bonferroni para a variável Ds nas diferentes áreas.

Tabela 11 - Porosidade total média (\%) nas áreas de estudo.

Tabela 12 - Valores médios do $\mathrm{pH}$ nas áreas de estudo.

Tabela 13 - Teores médios de Matéria Orgânica $\left(\mathrm{g} \cdot \mathrm{dm}^{-3}\right)$ nas áreas de estudo

Tabela 14 - Teores médios de Fósforo $\left(\mathrm{mg}^{-\mathrm{dm}^{-3}}\right)$ nas áreas de estudo.

Tabela 15 - Teores médios de Potássio $\left(\mathrm{mmolc}_{\mathrm{dm}}{ }^{-3}\right)$ nas áreas de estudo.

Tabela 16 - Teores médios de Cálcio $\left(\mathrm{mmolc} \mathrm{dm}^{-3}\right)$ nas áreas de estudo.

Tabela 17 - Teores médios de Magnésio $\left(\mathrm{mmolc}_{\mathrm{dm}}{ }^{-3}\right)$ nas áreas de estudo

Tabela 18 - Resultados médios da Soma de Bases $\left(\mathrm{mmolc}_{\mathrm{dm}}{ }^{-3}\right)$ nas áreas de estudo.

Tabela 19 - Teores médios de Alumínio $\left(\mathrm{mmolc}_{\mathrm{dm}}{ }^{-3}\right)$ nas áreas de estudo ..

Tabela 20 - Acidez Potencial ( $\mathrm{H}+\mathrm{Al})$ média $\left(\mathrm{mmolc} \cdot \mathrm{dm}^{-3}\right)$ nas áreas de estudo.

Tabela 21- Resultados médios da Capacidade de Troca Catiônica (mmolc. $\mathrm{dm}^{-3}$ ) nas áreas de estudo. 
Tabela 22 - Porcentagem média de Saturação de Bases (\%) nas áreas de Estudo.

Tabela 23 - Espécies arbóreas mais freqüentes nas áreas de estudo.

Tabela 24 - Circunferência à altura do peito $(\mathrm{CAP})$ média $(\mathrm{cm})$ das espécies arbóreas mais freqüentes nas áreas de estudo.

Tabela 25 - Altura média $(\mathrm{m})$ das espécies arbóreas mais freqüentes nas áreas de estudo.

Tabela 26 - Índice de Shannon-Wiener por parcela e por área.

Tabela 27 - Espécies arbóreas com emergência natural nas áreas revegetadas. 154

Tabela 28 - Correlações entre as variáveis físico-químicas do substrato

Tabela 29 - Indicadores de qualidade do substrato na revegetação da Mineração Descalvado. 


\section{LISTA DE FOTOS}

Foto 1 - Kit básico do trado amostrador. Destaque para o trado e o cilindro. ... 59

Foto 2 - Sequência de amostragem a $20 \mathrm{~cm}$ de profundidade.

Foto 3 - Obtenção da amostra indeformada e acondicionada para garantir sua preservação (conjunto).

Foto 4 - Foto aérea (2006) da Mineração Descalvado e a circunvizinhança. ..

Foto 5 - Tipos de vegetação na circunvizinhança da Mineração Descalvado (2007).

Foto 6 - Vista geral da cava e da área operacional de beneficiamento da mineração Descalvado (2007).

Foto 7 - Antiga bacia de disposição de rejeitos, já revegetada (ampliação de foto aérea de 2006).

Foto 8 - Amostragem a $80 \mathrm{~cm}$ de profundidade.

Foto 9 - Situação geral da bacia de rejeito (contorno em vermelho) antes do ano 1995.

Foto 10 - Vista aérea da Mineração Descalvado ( 2007), com destaque para a antiga bacia de rejeitos já revegetada (contorno em vermelho).

Foto 11 - Trincheiras apresentando material compactado na profundidade média de $60 \mathrm{~cm}$.

Foto 12 - Profundidade de raízes em torno dos $40 \mathrm{~cm}$ de profundidade. 96

Foto 13 - Perfis representativos do substrato na Área A1.

Foto 14 - Detalhe de mudas emergentes de Acacia poliphylla, (Monjoleiro) na área $\mathrm{A} 1$.

Foto 15 - Estado geral da vegetação da Área A1 (conjunto).

Foto 16: Perfis representativos do substrato na Área A2.

Foto 17 - Detalhes da vegetação e do substrato na Área A2 (conjunto). 103

Foto 18 - Vista geral da vegetação da Área A2 (11 anos). 104

Foto 19 - Detalhe do crescimento diferenciado do Adenanthera macrocarpa (Angico vermelho) na área $\mathrm{A} 2$.

Foto 20 - Perfis representativos do substrato da Área A3. 
Foto 21 - Detalhe da espécie arbórea nativa Xylopia aromatica (Pindaiba de macaco), colonizadora natural na na Área A3. .......................... 106

Foto 22 - Estado geral da vegetação da Área A3 (conjunto). ……................. 107

Foto 23 - Perfis representativos do substrato na Área A4. .............................. 108

Foto 24 - Detalhe da revegetação na Área A4. …….................................. 109

Foto 25 - Estado geral da vegetação da Área A4 (conjunto). ............................ 110

Foto 26 - Perfis representativos do solo da Área 5 de mata nativa. .................. 112

Foto 27 - Estado geral da vegetação na Área A5 de mata nativa (conjunto). .. 113

Foto 28 - Detalhe da camada de serrapilheira na Área A5 de mata nativa. ...... 114

Foto 29 - Bacia de rejeito sendo preenchida com material arenoso (estéril). ... 115

Foto 30 - Bacia de rejeito com destaque para estéril depositado. ................... 115

Foto 31 - Rejeito com consistência de lama (conjunto). .................................. 116 


\section{LISTA DE ABREVIATURAS, SIGLAS E SÍMBOLOS}

$\begin{array}{ll}\text { A1 } & \text { Área 1 } \\ \text { A2 } & \text { Área 2 } \\ \text { A3 } & \text { Área 3 } \\ \text { A4 } & \text { Área 4 } \\ \text { A5 } & \text { Área 5 } \\ \text { A6 } & \text { Área 6 } \\ \text { ABNT } & \text { Associação Brasileira de Normas Técnicas }\end{array}$

$\mathrm{AL} \quad$ Planícies aluvionares

Al

Alumínio

ALCOA Aluminium Company of America

CAP Circunferência à altura do peito

CEA-USP Centro de Estatística Aplicada da USP

${ }^{0} \mathrm{C} \quad$ Grau Celsius

$\mathrm{cm} \quad$ Centímetro

$\mathrm{cm}^{3} \quad$ Centímetro cúbico

CS Classe sucessional

CTC Capacidade de troca catiônica

CV Coeficiente de variação

Cwa Classificação do clima

Dc Diâmetro do cilindro

DNPM Departamento Nacional de Produção Mineral

Dp Densidade de partículas

DP Desvio padrão

Ds Densidade de solo

E Leste

EIA Estudo de Impacto Ambiental

EMBRAPA Empresa Brasileira de Pesquisa Agropecuária

EPUSP Escola Politécnica da USP

ESALQ Escola Superior de Agronomia Luiz de Queiroz 


\begin{tabular}{|c|c|}
\hline ETP & Evapotranspiração potencial \\
\hline ETR & Evapotranspiração real \\
\hline Euc. & Plantio de eucaliptos \\
\hline FAPESP & Fundação de Amparo à Pesquisa \\
\hline FES & Floresta Estacional Semidecidual \\
\hline g & Grama \\
\hline g.dm $\mathrm{dm}^{-3}$ & Grama por decímetro cúbico \\
\hline GPS & Global Positioning System \\
\hline $\mathrm{H}$ & Altura do cilindro \\
\hline $\mathrm{H}$ & Hidrogênio \\
\hline $\mathrm{H}+\mathrm{Al}$ & Acidez potencial \\
\hline ha & Hectare \\
\hline IAC & Instituto Agronômico de Campinas \\
\hline IBAMA & Instituto Brasileiro do Meio Ambiente e dos Recursos Naturais \\
\hline IPT & Instituto de Pesquisas Tecnológicas \\
\hline ISO & International Organization for Standardization \\
\hline K & Potássio \\
\hline $\mathrm{Kg}$ & Kilograma \\
\hline $\mathrm{Km}$ & Kilómetro \\
\hline LVa & Latossolo Vermelho-Amarelo \\
\hline$m^{2}$ & Metro quadrado \\
\hline $\mathrm{Mg}$ & Magnésio \\
\hline MG & Minas Gerais \\
\hline $\mathrm{mg} \cdot \mathrm{dm}^{-3}$ & Miligrama por decímetro cúbico \\
\hline Mg.m ${ }^{3}$ & Megagrama por metro cúbico \\
\hline $\mathrm{Mm}$ & Mimilímetro \\
\hline MMA & Ministerio de Medio Ambiente \\
\hline mmolc. $\mathrm{dm}^{-3}$ & Milimol de carga por decímetro cúbico \\
\hline MN & Mata nativa \\
\hline MNR & Mata nativa em regeneração \\
\hline MO & Matéria orgânica \\
\hline $\mathrm{mol} / \mathrm{l}$ & Mol por litro \\
\hline $\mathrm{N}$ & Norte \\
\hline
\end{tabular}




\begin{tabular}{|c|c|}
\hline NBR & Norma Brasileira \\
\hline NP & Não pioneiras \\
\hline O-I & Owens Illinois \\
\hline$P$ & Pioneiras \\
\hline PA & Pará \\
\hline Past & Pastagens \\
\hline PCA & Plano de Controle Ambiental \\
\hline $\mathrm{pH}$ & Potencial hidrogênio \\
\hline PRAD & Plano de Recuperação de Áreas Degradadas \\
\hline $\mathrm{R} 1$ & Trincheira 1 \\
\hline $\mathrm{R} 2$ & Trincheira 2 \\
\hline R3 & Trincheira 3 \\
\hline RAD & Recuperação de Áreas Degradadas \\
\hline Rev & Revegetações \\
\hline RIMA & Relatórios de Impacto Ambiental \\
\hline RO & Roraima \\
\hline SB & Soma de bases \\
\hline SER & Sociedade Internacional de Restauração Ecológica \\
\hline SMA & Secretaria de Meio Ambiente \\
\hline SOBRADE & $\begin{array}{l}\text { Sociedade Brasileira de Recuperação de Áreas } \\
\text { Degradadas }\end{array}$ \\
\hline SP & São Paulo \\
\hline t/mês & Toneladas por mês \\
\hline TAC & Termo de Ajuste de Conduta \\
\hline UFV & Universidade Federal de Viçosa \\
\hline UNESP & Universidade Estadual Paulista \\
\hline USP & Universidade de São Paulo \\
\hline UTM & Universal Transversa de Mercator \\
\hline V & Porcentagem de Saturação de Bases \\
\hline$V_{c}$ & Volume do cilindro \\
\hline
\end{tabular}




\section{SUMÀRIO}

INTRODUÇÃO

\section{CAPÍTULO 1 ASPECTOS GERAIS DO SOLO NA RECUPERAÇÃO}

1.1 O solo e sua degradação ……......................................................... 31

1.2 Recuperação do solo 33

1.2.1 O papel da vegetação na recuperação do solo ........................... 35

1.3 Qualidade de solo ........................................................................ 36

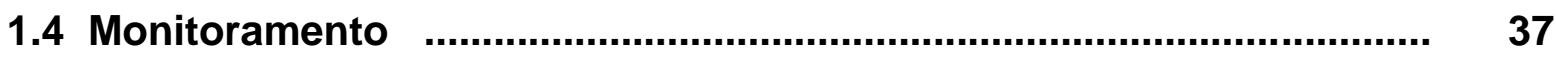

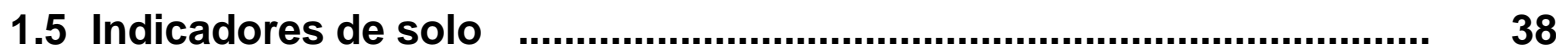

1.5.1 Indicadores físicos ................................................................ 42

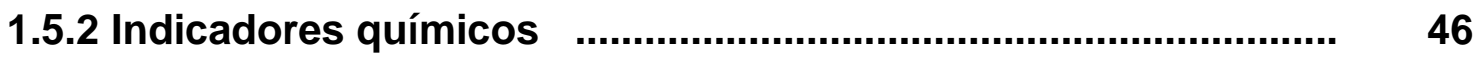

CAPÍTULO 2 METODOLOGIA PROPOSTA

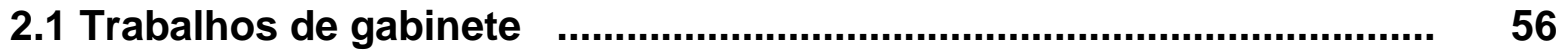

2.2 Trabalhos de campo ……............................................................. 56

2.2.1 Reconhecimento preliminar do local de estudo ....................... 57

2.2.2 Amostragem do substrato ...................................................... 57

2.2.2.1 Amostras indeformadas ........................................... 58

2.2.2.2 Amostras deformadas ................................................ 61

2.2.3 Avaliação do estado geral da vegetação arbórea

2.3 Ensaios de laboratório .................................................................. 62

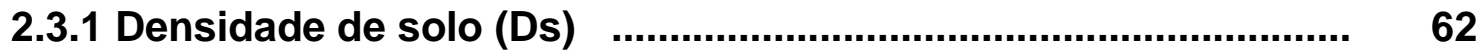

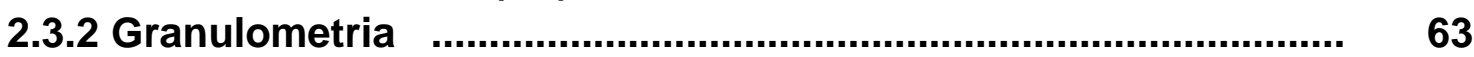

2.3.3 Densidade de partículas (Dp) …….......................................... 64

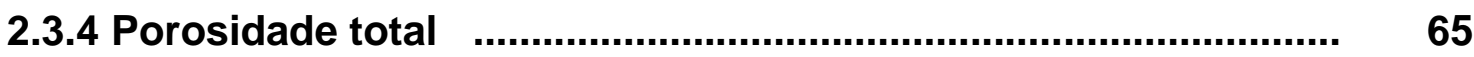

2.3.5 Determinação dos parâmetros químicos

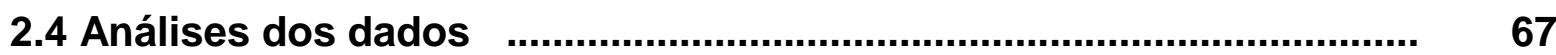

CAPÍTULO 3 ESTUDO DE CASO ………................................................ 69

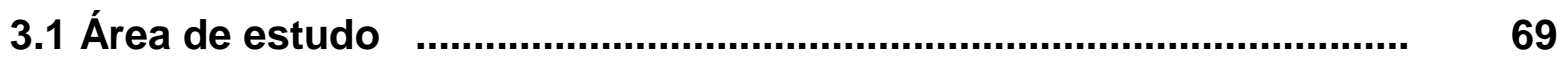

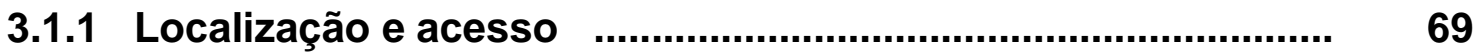


3.1.2 Caracterização ambiental da área

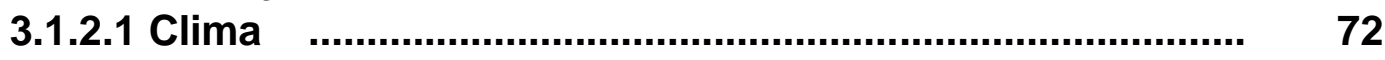

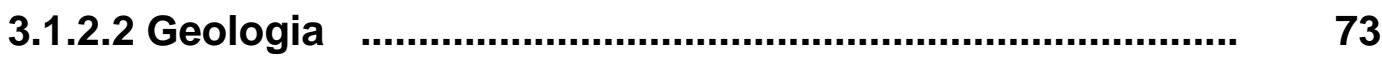

3.1.2.3 Geomorfologia .........................................................

3.1.2.4 Recursos hídricos ......................................................

3.1.2.5 Solos .......................................................................

3.1.2.6 Vegetação .................................................................. 76

3.1.3 O processo produtivo da Mineração Descalvado ………........ 78

3.1.4 Atividades de recuperação das áreas degradadas na mineração Descalvado

3.2 Aplicação metodológica …............................................................. 83

3.2.1 O local da pesquisa …............................................................ 83

3.2.2 Trabalhos de campo ……............................................. $\quad 85$

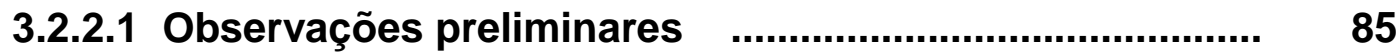

3.2.2.2. Amostragem do substrato …........................................ 86

3.2.2.3 Observações da vegetação ……………........................ 90

3.2.3 Ensaios de laboratório …........................................................ 91

3.3 Caracterização do substrato na bacia de rejeitos …………............. 92

3.4 Caracterização geral das áreas de estudo ……................................ 97

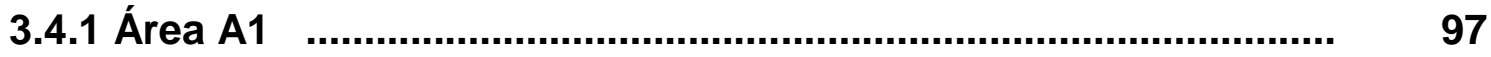

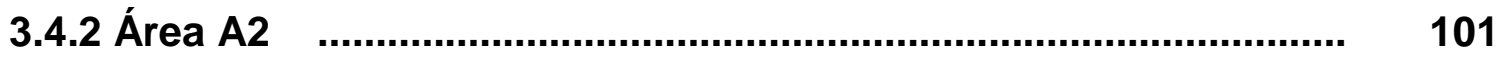

3.4.3 Área A3 …........................................................................ 105

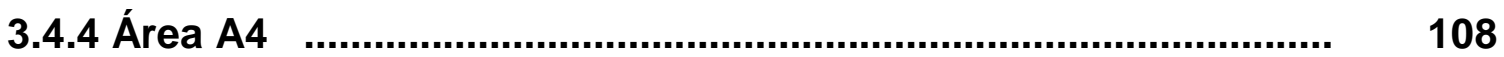

3.4.5 Área A5 ....................................................................... 111

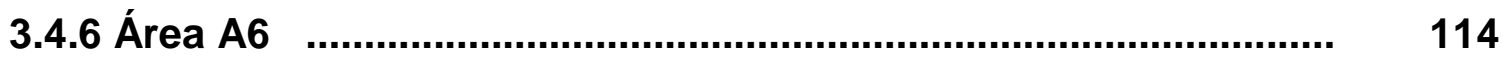

4.1 Resultados e comentários dos parâmetros físicos ………............ 120

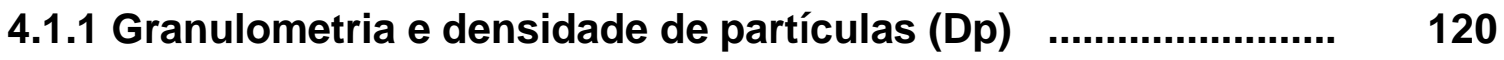

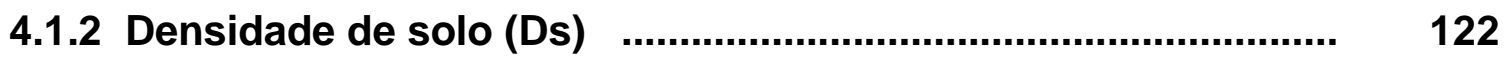

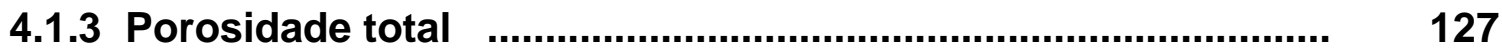

4.2 Resultados e comentários dos parâmetros químicos 129

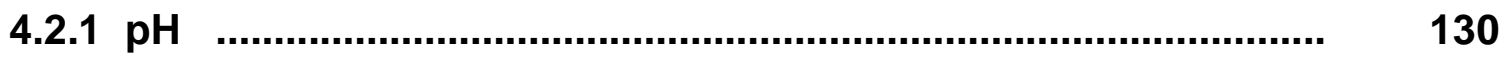

4.2.2 Teor de matéria orgânica (MO) …….................................... 131

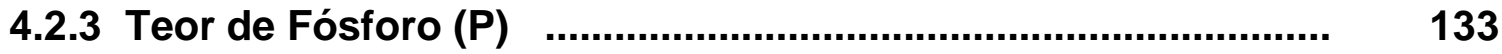

4.2.4 Teor de Potássio (K) ……................................................ 135

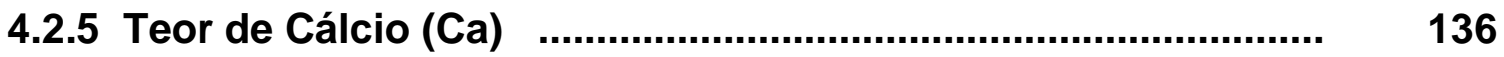

4.2.6 Teor de Magnésio $(\mathrm{Mg})$ 
4.2.7 Soma de Bases (SB)

4.2.8 Teor de Alumínio ............................................................... 139

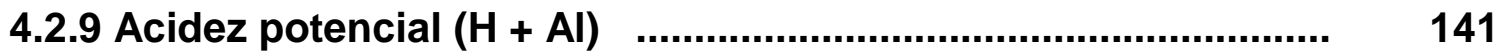

4.2.10 Capacidade de troca catiônica (CTC) ….............................. 142

4.2.11 Porcentagem de Saturação de bases (V) ............................. 144

4.3 Resultados e análise das observações da vegetação $\quad$.................... 145

4.3.1 Circunferência à altura do peito (CAP) $\quad$...................................... 147

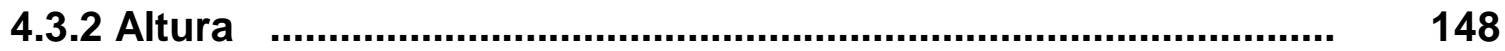

4.3.3 Diversidade

4.4 Relações entre parâmetros de solo e de vegetação

4.5 Avaliação de desempenho das áreas revegetadas $\quad$........................... 162

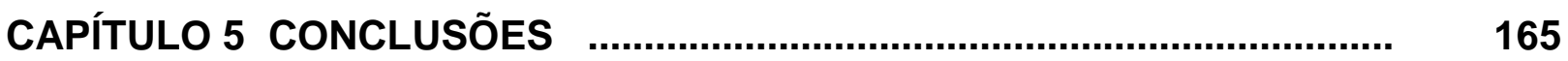

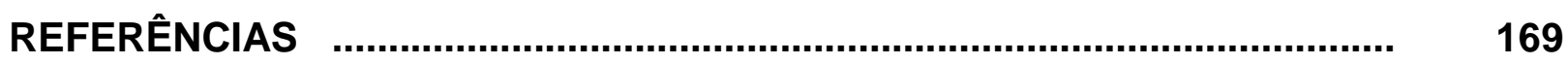

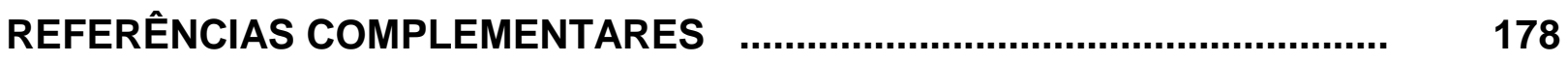

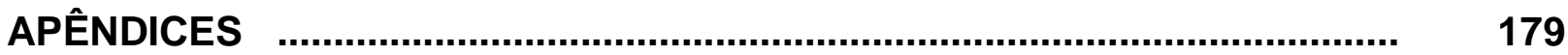

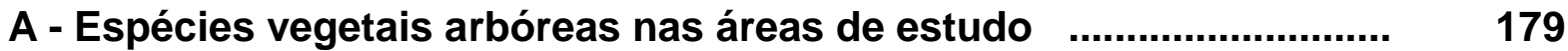

B - Medidas resumo das variáveis do substrato ................................. 185

C - Perfis médios das variáveis do substrato ….................................... 202

D - Análises granulométricas do substrato ......................................... 208

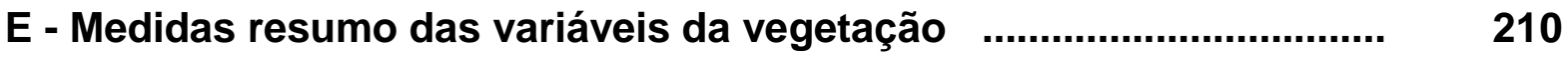

ANEXOS

A - Correlação entre variáveis do substrato …….................................. 222 


\section{INTRODUÇÃO}

Quando se trata de recuperação ambiental na mineração, nas suas diferentes modalidades, o restabelecimento da cobertura vegetal - conhecida como "revegetação" - tem um papel essencial. É possível traçar uma extensa retrospectiva sobre o aprimoramento ambiental em vigor, orientada ao tema, o que demonstra a preocupação do poder público quanto à garantia de resultados satisfatórios na recuperação de áreas degradadas envolvendo procedimentos de revegetação.

Recuperação de área degradada tem sido entendido como deixar a área em questão apta para um novo uso. As ações de recuperação ambiental na mineração requerem planejamento prévio, o que implica determinar qual deve ser o propósito da recuperação da área e decidir qual é a forma de uso esperada para tal área.

Na mineração de areia, uma forma de uso futuro muito utilizada é a revegetação das áreas com espécies nativas visando a conservação ambiental. Nesse caso, o objetivo é prestar serviços ambientais. Uma vez realizada a implantação do projeto de revegetação, surge a necessidade de aferir os resultados, conferir se os objetivos do trabalho foram alcançados e determinar a partir de quando esses resultados estão sendo satisfatórios. Só então poderá se confirmar que a área atende a critérios preestabelecidos de recuperação ambiental, ou seja, que "a área está recuperada".

A ferramenta usada para este controle é o monitoramento ambiental que, no contexto de recuperação de áreas degradadas, é o conjunto de ações ou procedimentos destinados a avaliar o avanço ou o sucesso da recuperação da área degradada. Mediante o monitoramento também vai ser possível documentar e demonstrar os resultados dos programas de gestão ambiental, avaliar as práticas de manejo utilizadas e orientar decisões, caso sejam necessárias novas ações (Sánchez, 2005).

Para contribuir com tal avaliação, surge a aplicação de indicadores de desempenho ambiental, que consiste no uso de parâmetros ambientais. Esses parâmetros devem ser selecionados por atenderem a determinados critérios, apropriados para prover informações sobre o estado do ambiente e a evolução deste em decorrência das ações de recuperação. 
Considerando que os impactos conseqüentes das ações degradadoras são diferentes e que cada caso de recuperação deve definir seus próprios objetivos e atender exigências individuais, o exercício de monitoramento também deve estabelecer seus próprios indicadores de desempenho e procedimentos que atendam a suas expectativas, segundo as circunstâncias de cada caso.

A mineração de areia, como qualquer outra atividade que gera impactos, requer, portanto, não só o estabelecimento de novas formas de uso futuro do ambiente degradado como também, mais especificamente, a definição dos indicadores de desempenho mais apropriados para a avaliação da recuperação. Inúmeros indicadores podem ser utilizados, embora os mais usuais estejam atualmente relacionados ao crescimento da vegetação. Em qualquer tipo adotado, outro grande desafio é desenvolver ou adaptar procedimentos, métodos e critérios válidos para a aplicação de cada indicador de maneira que forneçam, com exatidão, as informações desejadas a custos aceitáveis. Como contribuição a estes aspectos, alguns trabalhos como os de Bento (2009), Sautter (2007), Ré (2007), Knapik e Maranho (2007), Reis (2006) e Almeida (2002) já sugerem possíveis indicadores aplicáveis na avaliação de áreas mineradas revegetadas.

No caso da avaliação da recuperação das bacias de disposição de rejeitos, o monitoramento do solo acondicionado (substrato) se faz indispensável em vista da relação direta entre a qualidade deste e o desenvolvimento da vegetação. Nesta situação, o crescimento das plantas é mais difícil, em relação à revegetação de outras áreas afetadas pela mineração, devido às condições do substrato, quase sempre muito compacto e nutricionalmente pobre. São necessárias novas estratégias para o sucesso da revegetação em tais áreas, capazes de criar condições edáficas mais favoráveis para o desenvolvimento das espécies plantadas. Assim, se faz indispensável a reflexão sobre a importância da avaliação do estado do substrato como complemento da avaliação do estado da vegetação. Dessa maneira, as informações sobre a qualidade ambiental do local seriam mais completas e forneceriam dados mais elucidativos sobre a eficácia dos procedimentos de recuperação aplicados e a perspectiva de sustentabilidade no longo prazo. Daí a importância de se utilizarem indicadores da qualidade do solo 
como indicadores de desempenho da recuperação de uma área minerada, principalmente nos casos dos solos com degradação intensa. ${ }^{1}$

$\mathrm{Na}$ prática atual, as minerações de areia (tanto industrial quanto de construção civil) do Estado de São Paulo promovem a revegetação de bacias de disposição de rejeitos, usando procedimentos convencionais, ou seja, os mesmos procedimentos aplicados na revegetação de outras áreas degradadas pela mineração, que por sua vez assemelham-se a procedimentos aplicados para revegetar outros tipos de áreas degradadas. Desta forma, é lícito interrogar como irá se comportar a vegetação no médio e longo prazo (da ordem de décadas), devido à pequena espessura de solo orgânico recolocado e às características do substrato. Estas condições não se apresentam propícias para que a vegetação implantada se desenvolva com sucesso. Nas bacias de rejeito não há garantia de viabilidade dos plantios para a formação efetiva de uma comunidade vegetal e animal e a recomposição de um ecossistema em que estejam em equilíbrio o biótopo e a biocenose.

Sabe-se que períodos curtos de monitoramento ou de observação não são suficientes para que se conclua sobre o sucesso do plantio nem sobre sua sustentabilidade. O crescimento rápido da biomassa e mesmo o aumento da diversidade de plantas pode ser o resultado dos tratos iniciais, como a adubação e o plantio de mudas em covas ou do vigor de crescimento das espécies pioneiras, sem que isto necessariamente indique a recomposição do ecossistema ou o atingimento dos objetivos de recuperação da área.

Embora o processo de recuperação do substrato, como meio para o crescimento das plantas, tenha se mostrado muito lento (Corrêa, 2007), seu monitoramento, por meio da obtenção de medidas dos seus atributos funcionais, pode fornecer dados que indiquem as tendências desse processo, especialmente quando comparados aos dados de locais sem nenhuma ação de recuperação ou aos das áreas sem interferência da mineração ou, ainda, com remanescentes de vegetação nativa, tidas como áreas de referência.

O uso de indicadores de qualidade do solo oferece um modo indireto de avaliar a eficácia do processo de recuperação de áreas degradadas, o que pode auxiliar

\footnotetext{
${ }^{1}$ Frouz et al. (2002) asseveram que as condições do solo são de extrema importância na recuperação de um ecossistema e na sua auto-sustentabilidade, promovendo o crescimento das plantas, abrigando e protegendo flora e fauna, e mantendo a qualidade ambiental em geral.
} 
nas tarefas voltadas à gestão ambiental por parte da empresa e também contribuir tecnicamente para a fiscalização dos agentes governamentais.

Com base nos fundamentos apresentados, delineia-se a seguinte hipótese de trabalho desta investigação:

O estado geral dos substratos tem influência direta no crescimento da vegetação e permite estabelecer indicadores de desempenho que constituem uma ferramenta efetiva para avaliar o andamento da revegetação de áreas degradadas pela mineração de areia.

Objetivos da pesquisa

\author{
Objetivo Geral \\ Propor e testar a utilização de uma metodologia de monitoramento do \\ substrato, estabelecendo conexões com o desenvolvimento da vegetação, \\ de forma a avaliar conjuntamente o estado geral da revegetação nas áreas \\ degradadas pela mineração de areia.
}

\title{
Objetivos Específicos
}

a) Selecionar parâmetros representativos das condições do substrato para servirem como indicadores ambientais das condições do meio físico.

b) Avaliar o potencial de aplicação do método de estudo para fins de monitoramento ambiental e de acompanhamento dos resultados de programas de recuperação de áreas degradadas.

c) Analisar aspectos sobre as condições necessárias à promoção da sustentabilidade do substrato para garantir o sucesso da revegetação, ao longo do tempo.

\section{Justificativa}

A experiência acumulada sobre Recuperação de Áreas Degradadas (RADs) pela mineração em ambientes tropicais, particularmente no Brasil, permite apontar pelo menos duas lacunas graves. Primeiro, ocorre com freqüência uma incompatibilidade entre a concepção e a prática da revegetação, fato que acaba 
determinando uma baixa eficiência no propósito da reversão do estado de degradação (Bitar, 1997; Dias, 2001). A segunda lacuna refere-se a que, embora existam muitos trabalhos sobre revegetação de áreas degradadas, as pesquisas orientadas para a avaliação dos resultados, para o monitoramento e o uso de indicadores de sustentabilidade nas áreas revegetadas são menos freqüentes. Campello et al. (2000) justificam tal fato explicando que as pesquisas relacionadas à recuperação de áreas degradadas ainda estão formando suas bases de dados apoiadas em seus programas básicos de monitoramento de atividades implementadas para recuperar a qualidade do ambiente. Por outro lado, a grande diversidade de atividades antrópicas que provocam degradação ambiental, mesmo dentro de um setor específico como a mineração, aliada às características típicas dos diversos ecossistemas encontrados no território nacional, obriga à busca e definição de indicadores físicos e ecológicos de sustentabilidade para cada região e cada tipo de atividade mineira.

Ainda são poucos os estudos cientificamente fundamentados, contendo resultados e conclusões diretamente aplicáveis para orientar as práticas usuais nas minas, ou apontar parâmetros que sirvam como indicadores referenciais úteis para o aprimoramento das técnicas atualmente aplicadas. Esta situação é ainda mais difícil em casos especiais, tais como as bacias de disposição de rejeitos de areia, objeto de estudo desta pesquisa. Tal fato tem como reflexo certa padronização que se repete em muitos dos conteúdos dos Planos de Recuperação de Áreas Degradadas (PRADs), associado a uma prática que, na maioria dos casos, não costuma ser suficiente para garantir os quesitos planificados, bem como a inexistência de uma base rigorosa para se avaliar o estado geral de uma área revegetada.

O estabelecimento de critérios para a revegetação das áreas degradadas apresentados nas Resoluções SMA 42 de 1996, SMA 21 de 2001, SMA 47 de 2003 e SMA 8/2008 da Secretaria de Meio Ambiente do Estado de São Paulo é uma tentativa de estimular a melhoria dessa situação. No entanto, essas resoluções fazem apenas tênue menção aos aspectos relacionados com o manejo do solo, concentrando-se em parâmetros descritivos da parte aérea da vegetação. Barbosa (2006) aponta que a avaliação da recuperação da estrutura e fertilidade do solo, considerando-se situações com fortes fatores de degradação, como é caso da mineração de areia, deve ser objeto de análise, uma vez que poucas vezes este tema é tratado com profundidade. É importante lembrar que a simples recolocação 
do solo na superfície minerada não garante a recuperação; é preciso conjugar uma série de práticas orientada pelo uso futuro do local. Sobre esse aspecto, Fytas (2004) observa que na recuperação de bacias de rejeito deve-se almejar, primeiro, um objetivo químico, recriando o leito do solo no substrato estéril das bacias, tentando restaurar o balanço químico do sistema pelo incremento de matéria orgânica e nutrientes. O objetivo seguinte é biológico, com o restabelecimento da cobertura vegetal na área, de maneira a recobrar a integridade biológica do sistema. Um terceiro objetivo é biológico-estético, recuperando a diversidade de espécies mediante a colonização de plantas e animais nativos no local.

Quanto à magnitude do problema, justifica-se o desenvolvimento de uma pesquisa desta natureza pelo fato de que, no caso do território paulista, os minerais não metálicos perfazem 93\% da produção mineral do Estado (DNPM, 2000 apud TANNO; SINTONI, 2003). Destaca-se a mineração de agregados como a areia e o cascalho, que ocupa o primeiro lugar em volume produzido, com 43,5 milhões t/ano (TANNO; SINTONI, 2003). Segundo Cabral Junior \& Almeida apud Tanno e Sintoni (2003), esse valor poderia ser 1,5 a 2 vezes maior devido à defasagem dos dados estatísticos oficiais e à presença de uma parcela considerável de lavras não regulamentadas. Outro dado importante, da mesma fonte, é que a indústria mineral paulista é constituída, no mínimo, por três mil empreendimentos, predominando as empresas de pequeno e médio porte que exploram areia para construção civil, concentrada em determinadas regiões ou pólos produtores, quase sempre próximos a grandes centros urbanos. As empresas de grande porte representam menos de $10 \%$ do número total.

No caso específico da mineração de areia industrial, utilizada na produção de vidro, de produtos químicos e moldes de fundição, a fração de rejeito silte-argiloso pode representar até $20 \%$ do minério (Ferreira \& Daitx, 2003). Como o rejeito não possui aproveitamento econômico, os autores afirmam que este representa um dos principais problemas ambientais nessas minerações.

De acordo com a legislação, praticamente todas as minerações devem desenvolver algum tipo de revegetação em suas áreas operacionais. A modalidade de mineração de areia requer atenção especial, seja por questões de localização das áreas mineradas, de concentração de empreendimentos em regiões de fragilidade ambiental, da extensão dos territórios envolvidos e pela possibilidade de reintegração das áreas revegetadas para outros fins econômicos ou sociais. 
Novas iniciativas quanto à definição e estabelecimento de indicadores ambientais de solo, aplicados à revegetação de áreas mineradas, significam um salto qualitativo no status quo vigente, e com reflexos positivos na recuperação das áreas degradadas. É desejável que o incremento de pesquisas nesse campo venha auxiliar no processo de recuperação das áreas mineradas, visando a novos usos pós-mineração, e reduzir a formação de passivos ambientais, como tantos hoje existentes, devido aos erros de procedimentos, ou simples ausência de recuperação de áreas mineradas no passado. O estudo deverá trazer contribuições adicionais à avaliação de planos de recuperação colocados em prática. Espera-se que os resultados obtidos possam servir como referência técnica para balizar futuras resoluções dos órgãos de controle ambiental, ou como fonte de consulta e orientação para o meio técnico em geral ou, ainda, como base na condução de novas investigações sobre o tema. 


\section{CAPÍTULO 1}

\section{ASPECTOS GERAIS DO SOLO NA RECUPERAÇÃO AMBIENTAL}

Ao longo da história, as diversas atividades humanas têm ocasionado inúmeros impactos na natureza. Nos aspectos de flora, de acordo com o tipo de impacto, se inicia determinado processo de degradação do ambiente que pode ser desde a simples retirada de uma árvore, o corte integral de uma floresta até a movimentação ou retirada total do componente edáfico do local. Em muitos casos a capacidade de auto-regeneração do ambiente permite que ele recobre a sua condição. Em outros, não é mais possível retomar seu funcionamento rotineiro surgindo problemas como a dificuldade de estabelecimento da vegetação, erosão da área, perda de estrutura e compactação do solo, perda de nutrientes, desestruturação do perfil, e outros.

Atividades como mineração descaracterizam o solo de tal maneira que, o local perde a sua resiliência e torna-se inviável a regeneração da vegetação. Nesses casos é imprescindível realizar atividades de recuperação, que comumente incluem a manipulação de um substrato com vistas a melhorar as condições na implantação da vegetação. É o caso da mineração de areia.

\subsection{0 solo e a sua degradação}

O solo deve ser visto como um corpo tridimensional e não apenas a camada normalmente utilizada para avaliações de fertilidade. As ações do clima e dos organismos vivos, atuando ao longo do tempo sobre as rochas, sedimentos e materiais orgânicos, promovem sua transformação, originando diferentes solos sob variadas condições de relevo (REIS DUARTE; CASAGRANDE, 2006).

Autores como Panigatti, (2008); Primavesi (1981), Sautter (2007) apresentam o solo como uma corpo complexo, animado, praticamente vivo e que se modifica 
constantemente. Estimativas feitas para ecossistemas temperados indicam que a cada metro quadrado de solo (camada de $20 \mathrm{~cm}$ ) pode-se encontrar mais de um milhão de indivíduos. Calcula-se que existam aproximadamente 360.000 espécies habitando o solo (SAUTTER, 2007).

Ao observar o ecossistema, pode-se perceber a grande importância do solo pelas funções que desempenha: é a base de sustentação de toda a vegetação, é a fonte de nutrientes para as plantas e grande número de animais, e conserva a maior quantidade de água disponível para a absorção da flora e da fauna. Entre os processos que ocorrem no solo, a decomposição é considerada como um processo chave, pois disponibiliza nutrientes (mineralização) para o crescimento das plantas. Além disto, com a formação de colóides de carga negativa (humificação), a decomposição também aumenta a capacidade do solo de reter nutrientes na forma de cátions trocáveis.

Dias e Griffith (1998) asseveram que o conceito de degradação do solo pode ser relativo, dependendo da finalidade de uso atribuído a ele, e generalizam o conceito como qualquer alteração das condições naturais de seu equilíbrio. Em relação à atividade mineraria, IBAMA (1990) afirma que a degradação de uma área ocorre quando a vegetação nativa e a fauna são destruídas, removidas ou expulsas, a camada do solo fértil é perdida, removida ou enterrada; e a qualidade do regime de vazão do sistema hídrico é alterado. Para Gonçalves et al. (2003), solo degradado é aquele que sofreu perda parcial ou total de sua capacidade de sustentar o crescimento das plantas e outros organismos. Refere-se à perda de produtividade do solo através de trocas adversas em nutrientes, matéria orgânica, atributos ligados à estrutura e concentração de elementos tóxicos.

Reinert (1998) considera três tipos fundamentais de degradação do solo: física, química e biológica. A degradação física acontece no caso de perda das condições ligadas à forma (densidade, porosidade, infiltração, aeração) e à estabilidade da estrutura do solo. Tais problemas se refletem em limitações de aeração, na compactação da camada superficial, na diminuição da infiltração da água e no aumento do escoamento superficial que vai intensificando a erosão. A degradação química se manifesta quando há diminuição da fertilidade. As causas dessa perda podem ser das mais diversas, desde o aumento ou diminuição do $\mathrm{pH}$, perda ou diminuição de matéria orgânica, indisponibilidade dos nutrientes ou adição 
de substâncias que intensificam tais processos, como nos casos dos solos contaminados. A degradação biológica está associada à diminuição do teor de matéria orgânica e à perda da atividade biológica dos micro e macrorganismos que atuam na decomposição da matéria orgânica e na ciclagem de nutrientes. Misak et al. (2002) relacionam a degradação do solo com a redução significativa da sua porosidade, permeabilidade e capacidade de infiltração.

$\mathrm{Na}$ mineração a céu aberto, como é o caso da extração de areia, a degradação é intensa e envolve os três tipos citados anteriormente, pois há necessidade de remover as camadas superficiais e sub-superficiais do solo, com o qual se acaba reduzindo o volume e descaracterizando totalmente o espaço minerado.

\subsection{Recuperação do solo}

O termo recuperação no seu sentido amplo é definido por Sánchez (2005) como a forma de encontrar um novo uso produtivo para uma determinada área perturbada, que pode ser igual ou diferente do uso pré-mineração; devendo apresentar um equilíbrio dinâmico com a circunvizinhança. Para Corrêa (2006) a recuperação é um processo genérico que objetiva, sobretudo, alcançar a estabilidade do ambiente. Atualmente, a exploração mineral no Brasil necessita de prévia aprovação da atividade pelo setor ambiental governamental, que se utiliza dos Planos de Recuperação de Áreas Degradadas (PRADs) para viabilizar procedimentos que promovam e garantam essa estabilização da paisagem.

Reis Duarte e Casagrande (2006) assinalam que a recuperação de áreas degradadas deve levar em conta os componentes do sistema solo-planta-atmosfera buscando uma recuperação integrada dos processos biológicos.

$\mathrm{Na}$ prática o termo recuperação prevê atividades que permitem 0 desenvolvimento de vegetação, nativa ou exótica, nas áreas envolvidas com as operações de lavra, ou a reutilização do local para outros fins (CORRÊA, 2006). Na maioria das áreas mineradas no Brasil, a revegetação é a forma de recuperação 
mais utilizada, buscando retornar as condições de funcionamento do ecossistema em relação à sua estrutura (composição em espécies) e as funções ecológicas (ciclagem de nutrientes e biomassa). Para Reis Duarte e Casagrande (2006) a revegetação deve detectar problemas e buscar soluções em aspectos de solo (fertilidade física, biota, ciclagem de nutrientes, etc.), planta (botânica, fisiologia, interações com animais, etc.) e atmosfera (climatologia, física ambiental, etc).

Dentro de um plano de recuperação envolvendo revegetação, para áreas degradadas pela mineração de areia, as práticas de caráter edáfico estão contempladas por Almeida (2002) visando criar as condições necessárias ao desenvolvimento da vegetação.

Os procedimentos para a recuperação de solos degradados têm como base o resgate das funções desempenhadas pelos solos em relação ao crescimento das plantas: atuar como suporte e prover água e nutrientes em quantidades suficientes para seu desenvolvimento normal. Após a avaliação do estado do solo e dependendo do seu grau de degradação, pode-se realizar uma série de ações tentando reverter o quadro. Em áreas agrícolas, o objetivo na maioria dos casos é recobrar a fertilidade perdida ao longo de anos de lavoura. Nas áreas de pastagens o principal problema a solucionar é o declínio da produtividade por problemas de compactação dos solos. No caso de áreas mineradas o objetivo principal é a reconstrução do solo, tentando acondicionar um substrato para sua utilização como meio de crescimento da vegetação, para suprir a falta de solo ou para substituir solos contaminados.

O termo recuperação indica a melhoria da qualidade de um solo degradado no sentido de adquirir novamente suas condições originais (REINERT, 1998). Como essa melhoria pode levar décadas ou séculos, o termo recuperação de solo é usado de forma geral para todas as atividades que possam desencadear esse processo de melhoria. Em muitos casos, a recuperação só poderá ser possível para recuperar as suas funções, mas não sua forma, como acontece com os locais de mineração, onde o propósito é realizar a reconstrução do solo mediante o desenvolvimento de uma camada com material e características que permitam o desenvolvimento das plantas (CORRÊA, 2007). É o caso da mineração de areia do presente trabalho, onde os rejeitos, assim como a camada de estéril, depositados na área de estudo, serão denominados de substrato, como propõem Dias (1998) e Reis (2006). 
Como características do solo, Dias (1998) descreve os aspectos de existência de horizontes definidos, decorrentes do processo de intemperismo da rocha matriz ou sedimentos; a presença de um horizonte superficial onde se encontram maiores concentrações de carbono orgânico e, associada a este horizonte, uma biota. A base para a distinção entre solo e substrato seriam os parâmetros estratificação natural, matéria orgânica e biota.

Segundo Reis Duarte e Casagrande (2006) a recuperação do solo deve ser abordada do ponto de vista químico, físico e biológico. Em cada caso, a questão básica é saber como e quando foi degradado, para que se possa planejar o processo de recuperação. Como ações de recuperação de um substrato de mineração Corrêa (2006) aponta os tratamentos físicos: escarificação, subsolagem, gradeação, aração, terraceamento, coveamento e incorporação de matéria orgânica. Os tratamentos químicos: calagem, gessagem, aplicação de matéria orgânica e de fertilizantes. E os tratamentos biológicos: incorporação de matéria orgânica, inoculação de microorganismos e minhocas.

\subsubsection{O papel da vegetação na recuperação do solo}

A esse respeito, Souza (1997) e Lu et al. (2002) consideram que a revegetação desempenha um papel muito importante na recuperação do solo mediante a acumulação de biomassa e a melhora das interações solo/planta. A vegetação protege o solo da desidratação, compactação e danos por chuva. A cobertura vegetal afeta a temperatura e a umidade do solo e forma um microambiente apropriado para o crescimento da vegetação. A fertilidade é modificada à medida que há maior acumulação de biomassa e ganho do volume de serrapilheira e matéria orgânica. Numa avaliação de solos realizada na Amazônia, Lu et al. (2002) constataram que a revegetação de áreas degradadas pela construção de rodovias incrementou significativamente a fertilidade e melhorou a estrutura do solo. Varela et al. (2001) identificaram mudanças significativas na densidade aparente, na porosidade total, na distribuição de poros, na estabilidade de agregados e na resistência à penetração de raízes pela retirada de vegetação e modificação da topografia de uma área com clima temperado ao noroeste de Espanha. Um ano após o plantio de grama, nesta área, observou-se uma rápida 
recuperação das propriedades físicas do solo acondicionado com exceção da resistência à penetração.

\subsection{Qualidade do solo}

As primeiras aproximações do conceito de qualidade de solo estavam ligadas à aptidão de uso e produtividade agrícola. Sendo o solo um componente essencial da biosfera da Terra, a qualidade de solo não pode caminhar separada da idéia de sistema sustentável, tal como afirma Carter (2002). Já, o conceito atual de qualidade de solo envolve muitas funções que ele desempenha no ecossistema. Assim, para autores como Larson e Pierce (1994), a qualidade do solo está especificamente relacionada a sua habilidade em funcionar como um meio para o crescimento das plantas, na regulação e distribuição de fluxo de água no ambiente e seu funcionamento como um buffer (zona com efeito tampão) ambiental. Em termos práticos, a qualidade de solo para eles significa adequação ao uso ('fitness for use').

Para Pierzynski et al. (1994), as propriedades físicas e químicas do solo podem ser quantificadas e correlacionadas com a qualidade ambiental. Propriedades físicas, como densidade e textura, influenciam a aeração, a permeabilidade e a capacidade de retenção de água no solo. Propriedades químicas relevantes são as concentrações de constituintes orgânicos e inorgânicos que determinam características como fertilidade de solo, atividade biológica, grau de poluição, salinidade e outras.

$\mathrm{Na}$ prática, os mesmos autores consideram que a qualidade de solo está relacionada com a sua capacidade de produzir alimentos, fibras ou plantas, ou ainda, de manter um ecossistema para algum uso predeterminado. Quando se fala em manter um ecossistema, um caso ilustrativo é o solo que se desenvolve na Mata Atlântica. No momento em que sua vegetação é removida e substituída, com lavoura ou pastagens, a produtividade só poderá perdurar por alguns anos devido à diminuição da matéria orgânica e nutrientes do solo, associada à redução das sua qualidade física. Tais fatos acontecem por conseqüência da exposição do solo às condições de maior oxidação e à rápida erosão em zonas de alta pluviosidade. Decorrido um período de tempo, a erosão e as mudanças na fertilidade irão 
determinar a inaptidão do solo de sustentar um ecossistema ou cultura, tendo, diminuída dramaticamente sua qualidade.

Todos estes autores (Carter, 2002; Larson e Pierce, 1994; Pierzynski et al., 1994) concordam em definir qualidade do solo como uma função de alguns de seus atributos e propõem estabelecer um número mínimo desses para efeito de monitoramento, de maneira a servir como indicadores da mudança da sua qualidade. Lima et al. (2008) assinalam que o monitoramento adequado e contínuo de parâmetros físicos é promissor e que pesquisas futuras são necessárias para avaliar adequadamente a qualidade do solo de uma forma mais dinâmica ao longo do tempo, principalmente na recuperação de áreas degradadas.

\subsection{Monitoramento}

Monitoramento deve ser compreendido como o conjunto de ações ou procedimentos destinados a avaliar o sucesso ou o avanço da recuperação de um solo degradado. O monitoramento pode ser aperfeiçoado com a utilização de indicadores ambientais, principalmente aqueles denominados indicadores de desempenho ambiental, uma vez que informam sobre os resultados das ações de recuperação. $O$ objetivo é verificar se as metas delineadas estão sendo atingidas e se existem aspectos que devam ser reavaliados ou ajustados e, dessa maneira, obter indicação sobre o sucesso da recuperação (SÁNCHEZ, 2005).

O processo de melhoria dos solos degradados é muito lento. No entanto, o monitoramento (por meio da obtenção de medidas dos seus atributos funcionais) pode fornecer dados que indiquem as tendências dessa melhoria, especialmente se forem comparados às condições originais de cada local. Por exemplo, trabalhandose numa região de floresta tropical, tem-se como referencial a própria floresta, seja em termos de qualidade de solo, de composição florística ou de formação de biomassa (SALOMÃO et al., 1997; RUIZ-JAEN; AIDE, 2005). O exercício de monitoramento terá cumprido o seu papel quando os atributos medidos no ambiente em recuperação demonstrem uma trajetória apropriada de desenvolvimento ecológico focada na meta ou referência estabelecida (SER, 2004; RODRIGUES; GANDOLFI, 1998). 
Na situação específica das áreas revegetadas de disposição de rejeitos de areia, o monitoramento é de suma relevância, tendo em vista as condições adversas do substrato que apresenta, quase na sua totalidade, material fino (WHITAKER, 2001; CUCHIERATO, 2000). Esse fato determina alto grau de compactação, baixa porosidade, aeração pobre e umidade excessiva (FYTAS, 2004), fatores que influenciam negativamente o desenvolvimento da vegetação, e que podem constituir um obstáculo à autosustentabilidade dos locais revegetados no longo prazo, caso não tenham o manejo apropriado.

Os trabalhos da ALCOA (2009), em relação à mineração de bauxita consideram o monitoramento de áreas mineradas como a atividade para avaliar o sucesso da reabilitação, identificando locais que precisam ser retrabalhados, permitindo melhorias nas técnicas de reabilitação e determinando a sustentabilidade da reabilitação a longo prazo, e sua aptidão para que a área se integre às práticas convencionais de manejo florestal. Como a empresa já possui um conjunto de critérios ("completion critéria") que indicam o andamento das ações e incluem padrões, o monitoramento também gera subsídios para saber quando esses padrões estão sendo alcançados.

\subsection{Indicadores da qualidade do solo}

Indicador deriva da palavra indicare que significa destacar ou revelar algo. Indicadores são informações de caráter quantitativo utilizadas como ferramentas de auxilio à decisão (MAGALHÃES, 2007). Este mesmo autor acrescenta que são modelos simplificados da realidade com a capacidade de facilitar a compreensão dos fenômenos, de aumentar a aptidão de comunicação de dados brutos, e de adaptar informações à linguagem aos interesses locais e aos tomadores de decisão.

Um indicador ambiental constitui-se de um parâmetro síntese e representativo que permite derivar um conhecimento sobre o conjunto do ecossistema (MMA, 1996). Ainda de acordo com esta fonte, o indicador ambiental é "uma variável ou estimação do meio ambiente capaz de fornecer uma informação agregada e sintética sobre um fenômeno ambiental de relevância social, ou seja, que interesse na tomada de decisões e na informação pública em geral'. Essa 
mesma fonte afirma que o uso de indicadores ambientais pode ser justificado, primeiro, pela necessidade crescente de contar com informação adequada para a avaliação e o monitoramento dos resultados obtidos, assim como para a tomada de decisões por parte dos interessados (empreendedor, poder público, etc.); e segundo, para focalizar a informação científica potencial, de modo a obter os atributos ou parâmetros que representem as informações desejadas.

Corrêa (2007) resume o conceito de indicador de solo como a propriedade, processo ou característica mensurável usado para monitorar mudanças. E Valcárcel (2007) acrescenta que esses devem ser usados para caracterizar as relações funcionais dos ecossistemas nativos, acompanhar distúrbios provocados pelas ações exógenas e evidenciar níveis de resiliência de ecossistemas antropizados. $O$ autor também comenta que eles podem ser usados para propor estratégias de RADs, assim como para monitorar a efetividade das ações de RADs e avalizar o comportamento ambiental de áreas recuperadas.

Como requisitos que um bom indicador deve possuir, Doran e Parkin (1994), apud Corrêa (2007), assinalam que deve ter a capacidade de retratar a condição geral do meio. Também devem ser sensíveis às mudanças e apresentarem correlação satisfatória com os processos e/ou atributos que pretendem retratar (CORRÊA, 2007; DEDECEK, 2007). Embora existam muitas características desejáveis para um indicador, a simplicidade e clareza parecem ser os melhores atributos para selecioná-los de forma a evitar confusões na aplicação ou interpretação, assim como o baixo custo de aplicação. Manoliades (2002) acrescenta que os indicadores estabelecidos devem estar intimamente ligados aos objetivos do projeto, propiciar a abordagem efetiva do processo, ter alta qualidade e confiabilidade e considerar as escalas temporal e espacial adequadas. Möllerherm e Martens (2004), e Irimie (2002), comentam que os indicadores ambientais são o melhor instrumento para medir o progresso em direção à sustentabilidade.

O estado do solo indica a sua capacidade de funcionar no ecossistema como elemento sustentador da produtividade biológica, mantendo a qualidade ambiental e promovendo a saúde das plantas e animais. Com base nesta correlação entre o solo e vegetação, pode-se fazer uso de indicadores sobre a melhora na recuperação da qualidade de solo ou substrato para analisar-se a eficácia da recuperação do local como um todo, especialmente quanto à sua capacidade para sustentar determinada 
população vegetal e/ou animal. Portanto, dentro do conceito de ecossistema, o uso de indicadores de solo oferece uma maneira indireta de avaliar a eficácia do processo de recuperação de áreas degradadas, o que pode auxiliar nas tarefas de gestão ambiental por parte das empresas e/ou facilitar a fiscalização dos agentes governamentais.

Na recuperação ambiental de áreas degradadas pela mineração, o processo de observação dos meios físico, biótico e antrópico de cada local afetado tem como finalidade avaliar os efeitos das medidas mitigadoras dos impactos ambientais (CAMPELLO et al., 2000). Em termos de melhoria das características do substrato, estes autores sugerem variáveis biológicas, químicas e físicas que devem ser utilizadas como indicadores e estudadas em conjunto. Indicadores biológicos sugeridos são a taxa de respiração, quantidades de carbono, nitrogênio e fósforo contidos na biomassa microbiana e, quantidades de nitrogênio, fósforo e enxofre potencialmente mineralizáveis. Para indicadores químicos sugerem que sejam utilizadas as variáveis para avaliação da fertilidade do solo $(\mathrm{pH}$ em água, carbono orgânico total, fósforo, e potássio disponíveis; cálcio, magnésio, e alumínio trocáveis, soma de bases, capacidade de troca de cátions e condutividade elétrica). Como variáveis físicas, sugerem a caracterização da estrutura, da densidade do solo, resistência ao penetrômetro, capacidade de retenção de água, e profundidade média do sistema radicular das espécies de maior presença.

Especificamente para solos, Reinert (1998) classifica os indicadores em:

Descritivos - Indicadores visuais e morfológicos como crosta superficial, cor, cobertura, friabilidade, sulcos, erosão laminar, drenagem, etc.;

Analíticos - (1) físicos: textura, profundidade efetiva, densidade de solo, infiltração de água, estrutura, temperatura, etc.; (2) químicos: quantidade total de carbono e nitrogênio, quantidades de fósforo, potássio, alumínio, nitritos, nitratos, e metais pesados, $\mathrm{pH}$, capacidade de troca catiônica; e (3) biológicos: quantidade de carbono e nitrogênio na biomassa microbiana, nitrogênio mineralizável, taxa de respiração, população de minhocas, e outros. O autor enfatiza que a medição destes indicadores propicia uma poderosa ferramenta na avaliação da qualidade do solo.

Almeida e Sánchez (2005) também afirmam que conhecer as características do solo torna-se imprescindível para delinear a sua contribuição no sucesso da revegetação e aporte na sustentabilidade do ecossistema em formação. Propõem 
alguns indicadores de solo que podem ser utilizados, dando destaque aos valores de referência respectivos à zona de Mata Atlântica do Estado de São Paulo. Alguns estudos de monitoramento ambiental para áreas em processo de reabilitação como os de Tokgöz (2004), Frouz et al., (2002), Singh e Matho (2000), Parrota e Knowles (2001) e EMBRAPA (2007) já abordam a importância de se incluir a observação das melhorias no meio edáfico em conjunto com a estrutura fitossociológica e a regeneração natural. Tais práticas se devem aplicar, principalmente, em áreas de restauração destinadas ao uso como reservas florestais, hortos florestais e outras onde se pretenda estabelecer a revegetação de forma permanente.

Em 2004, a Sociedade Internacional de Restauração Ecológica (SER) emitiu uma lista de nove atributos do ecossistema como diretriz para quantificar ou medir o sucesso da restauração. Alguns atributos fazem alusão à procura pelo estabelecimento de um ecossistema o mais próximo possível àquele tido como referência, quanto à sua estrutura e funcionalidade e à sua integração com a matriz ecológica e a paisagem; outros mencionam a resiliência e a auto-sustentabilidade do ecossistema. Especificamente, nomeia-se o ambiente físico, pela sua capacidade de sustentar populações reprodutivas das espécies necessárias para uma estabilidade continua ou para um desenvolvimento no transcorrer de uma trajetória desejada (SER, 2004).

Mais recentemente, Ruiz-Jaen e Aide (2005) manifestam que existem três categorias de atributos que se devem considerar para avaliar o sucesso da restauração: 1) de diversidade, (2) da estrutura da vegetação e (3) de processos ecológicos. Esses últimos não são medidos muito freqüentemente, porque a recuperação dos processos ecológicos é mais lenta em comparação as outras categorias e também porque requerem medidas múltiplas que podem aumentar 0 tempo e o custo do projeto. Para contornar estas dificuldades, a maioria das medidas dos processos ecológicos se vale de indicadores. A disponibilidade de nutrientes, matéria orgânica do solo, dinâmica da serrapilheira, entre outros, são medidos para avaliar o processo de ciclagem de nutrientes, ligado diretamente ao conceito de qualidade de solo.

Segundo Zueng-Sang (2008) nenhum indicador, individualmente, irá descrever e quantificar todos os aspectos da qualidade do solo. Uma única função do solo também não poderia ser avaliada, já que todos os atributos do solo têm que 
ser relacionados uns com os outros. Os autores estabelecem cinco critérios para a seleção de indicadores de monitoramento da qualidade de solos: (1) devem integrar propriedades e processos químicos, físicos e biológicos e representar as propriedades e funções do solo que são mais difíceis de medir diretamente; (2) a relevância ecológica e a variação natural dos indicadores devem ser amplamente conhecidas; (3) devem ser sensíveis a variações em longo prazo, no manejo e no clima, mas resistentes a flutuações em curto prazo devido a mudanças climáticas ou ao desenvolvimento de culturas; (4) devem possibilitar sua medição acurada e precisa para uma ampla variação de tipos e condições de solo; e (5) devem ser determinações simples e de baixo custo, para permitir que grande número de análises possa ser realizado.

\subsubsection{Indicadores físicos}

Uma pré-seleção das variáveis escolhidas para o estudo e suas principais características teve como requisito de escolha o seu caráter prático, isto é, serem de fácil amostragem, com métodos de determinação de ampla difusão e cujos resultados e interpretação possam ser prontamente captados pela maioria de interessados. No decorrer do estudo poderão ser identificadas, como possíveis indicadores de avaliação, visando prover monitoramento como instrumento de observação na gestão ambiental de áreas revegetadas.

- Textura

Brady e Weil (2007) comentam que das três fases que compõem o solo (sólida, líquida e gasosa), a fase sólida é constituída por partículas minerais, componentes amorfos como a matéria orgânica, e os óxidos de ferro hidratados, que se encontram geralmente aderidos às partículas citadas. A textura do solo denota a medição da distribuição dos tamanhos de partículas e a proporção dos grupos de tamanhos de partículas compondo um solo. O método de caracterização do tamanho de partículas divide as partículas, com base no seu diâmetro, em três frações nomeados areia $(0,05 \mathrm{~mm}$ a $2 \mathrm{~mm})$, silte $(0,05$ e $0,002 \mathrm{~mm})$ e argila (menores que $0,002 \mathrm{~mm}$ ). A sua determinação é importante para o entendimento do comportamento e manejo do solo. Em geral, solos arenosos apresentam baixa 
capacidade de retenção de água, teor de matéria orgânica e capacidade de armazenamento de nutrientes; apresentam pouca susceptibilidade à compactação e têm boa drenagem e aeração. Já os solos argilosos têm alta capacidade de retenção de água e de armazenamento de nutrientes e matéria orgânica, mas, em compensação, sua drenagem e aeração são pobres e sua susceptibilidade à compactação é alta.

Como a textura não é prontamente sujeita às mudanças, ela é considerada como uma propriedade básica do solo que não poderá ser usada como indicador num contexto de avaliação, mas poderá ser útil como instrumento de manejo (LARSON; PIERCE, 2004). Assim, o conhecimento dessa característica vai nortear as medidas que podem ser tomadas para recuperação de um solo.

A Tabela 1 fornece informações úteis da influência das frações de areia, silte e argila sobre algumas propriedades e comportamento do solo.

Tabela 1: Influência das frações areia, silte e argila no comportamento do solo.

\begin{tabular}{|c|c|c|c|}
\hline $\begin{array}{c}\text { Propriedades/Comportamento do } \\
\text { solo }\end{array}$ & Areia & Silte & Argila \\
\hline Capacidade de retenção de água & Baixa & $\begin{array}{c}\text { Média a } \\
\text { alta }\end{array}$ & Alta \\
\hline Aeração & Boa & Média & Pobre \\
\hline Taxa de drenagem & Alta & $\begin{array}{c}\text { Lenta a } \\
\text { média }\end{array}$ & Muito lenta \\
\hline $\begin{array}{c}\text { Teor de matéria orgânica no solo } \\
\text { Decomposição de matéria } \\
\text { orgânica }\end{array}$ & Baixo & $\begin{array}{c}\text { Médio a } \\
\text { alto }\end{array}$ & Alto a médio \\
\hline Susceptibilidade à compactação & Baixa & $\begin{array}{c}\text { Média } \\
\text { Média }\end{array}$ & Lenta \\
\hline $\begin{array}{c}\text { Susceptibilidade à erosão eólica } \\
\text { Modera }\end{array}$ & Alta & Baixa \\
\hline $\begin{array}{c}\text { Susceptibilidade à erosão hídrica } \\
\text { Baixa }\end{array}$ & $\begin{array}{c}\text { Alta } \\
\text { Solo agregado: } \\
\text { baixa }\end{array}$ \\
\hline $\begin{array}{c}\text { Capacidade de armazenamento de } \\
\text { nutrientes }\end{array}$ & Baixa & $\begin{array}{c}\text { Média a } \\
\text { alta }\end{array}$ & $\begin{array}{c}\text { Solo não agregado: } \\
\text { alta }\end{array}$ \\
\hline Resistência a mudança de pH & Baixa & Média & Alta \\
\hline \multicolumn{2}{|c|}{ Fonte: (modificado de Brady e Weil, 2007) } & \\
\hline
\end{tabular}




\section{- Porosidade}

A porosidade é o índice relativo ao espaço ocupado pelo ar e pela água no solo. Geralmente, varia de $30 \%$ em solos compactados a $60 \%$ em solos superficiais agregados e com alto teor de matéria orgânica. Os poros são classificados segundo seu diâmetro em macroporos ( $>0,08 \mathrm{~mm}$ ) e microporos $(<0,08 \mathrm{~mm})$. Nos macroporos acontece a movimentação da água, do ar e o crescimento das raízes. Podem ocorrer como espaços entre partículas de areia em solos de textura grosseira e como espaços entre agregados em solos bem estruturados. Macroporos criados por raízes, minhocas e outros organismos constituem os bioporos, com formato tubular (PRIMAVESSI, 1981). Vegetações perenes como florestas e certas gramíneas são particularmente eficientes na criação de bioporos, após a morte e decomposição de raízes. Os microporos geralmente são ocupados por água, mas a maior parte da água retida nesses poros não está disponível para as plantas. Em solos argilosos, onde há maior quantidade de microporos, a aeração pode ser inadequada para um bom desenvolvimento radicular e atividade microbioólogica.

Segundo Fontes (1991), o balanço entre ambos é muito importante, na medida em que, quando uma parte da água que chega ao solo fica retida e à disposição das plantas (microporos), a outra parte percola, através do solo ou substrato, promovendo uma boa aeração (macroporos). Diz-se que um solo está compactado quando há uma diminuição do seu volume, que determina a redução da sua porosidade. A camada compactada dificulta a penetração das raízes e a percolação da água. A porosidade está estreitamente relacionada com a estrutura, pois um solo desagregado não tem porosidade, e também não permitirá o fluxo do ar e da água, dando lugar, em caso de chuvas, à formação de enxurradas e aos conseqüentes problemas de erosão e assoreamento.

A macroporosidade é também chamada de porosidade de aeração, porque é a porosidade encontrada após ter ocorrido a percolação da maior parte da água gravitacional; é o momento em que o ar passa a ocupar os poros não capilares.

Os solos que têm menor porosidade total são os arenosos porque nos argilosos, o maior teor de argila coloidal contribui para formarem agregados. (BRADY; WEIL, 2007). 


\section{- Densidade do solo}

A densidade do solo é definida como a relação entre a massa de solo seco pelo seu volume total, que inclui partículas sólidas e o espaço poroso do solo. É um atributo físico importante por fornecer indicações a respeito do estado da estrutura do solo e sua conservação, sendo uma das primeiras propriedades a ser alterada pelos diferentes usos, portanto é um indicador primário sobre a situação física do solo. Qualquer alteração na densidade é refletida na porosidade do solo e, portanto na sua estrutura (KLEIN, 2007). Dependendo do tipo de alteração e de sua intensidade, conseqüências significativas surgirão na retenção e movimento da água no solo, incluindo a infiltração e a aeração. A compactação ou adensamento do solo aumenta a resistência mecânica à penetração das raízes. Ocorre também a destruição da porosidade e conseqüentemente, uma redução na condutividade hidráulica e na permeabilidade ao ar, o que prejudica a respiração radicular. A movimentação de material fino dos horizontes superiores (eluviação) também contribui para a redução dos espaços porosos, aumentando a densidade dessas camadas. Em resumo, quanto maior a densidade, tanto mais compacto é o solo e em decorrência, tem menor porosidade.

Solos de textura fina geralmente possuem menor densidade em relação aos solos arenosos. Isto acontece porque os solos arenosos têm menor conteúdo de matéria orgânica e as partículas sólidas estão menos dispostas a formarem agregados possuindo menor quantidade de microporos. O crescimento radicular em solos úmidos é geralmente limitado às densidades variando de $1,45 \mathrm{Mg}^{-3} \mathrm{~m}^{-3}$ (solos argilosos) a 1,85 Mg.m. (solos franco-arenosos) (BRADY; WEIL, 2007).

$\mathrm{Na}$ recuperação de solos severamente compactados (densidades próximas de 2,0 Mg.m ${ }^{-3}$ ), como aqueles gerados por veículos pesados durante a construção e uso de aterro sanitário ou áreas de empréstimo é necessário quebrá-los mecanicamente para permitir o estabelecimento de árvores ou outro tipo de vegetação. Corrêa (2006) indica que é possível utilizar operações de escarificação , subsolagem, gradeação ou aração para tal propósito. Em áreas com ações de mobilização dos solos como é o caso das minerações, a recomposição, quase sempre com material estéril, cria novas condições de estruturação que precisam ser estudadas caso a caso. 


\subsubsection{Indicadores químicos}

As determinações químicas do solo têm sido largamente citadas como bons indicadores da qualidade de solo. A definição, de qual ou quais determinações podem ou devem ser utilizados como indicadores, não tem consenso entre os pesquisadores, uma vez que todos eles apresentam potencialidades e limitações e tem que se adequar às diferentes situações e finalidades.

Reis (2006) manifesta que dentre os métodos disponíveis para a avaliação da fertilidade do solo, o que reúne maior número de vantagens é a análise química de amostras de solo representativas da área sob estudo. Tais vantagens compreendem a rapidez, facilidade de execução, baixo custo e viabilidade dos resultados serem obtidos em tempo hábil para o planejamento, antes da implantação de qualquer tipo de vegetação ou para o monitoramento do local.

Os dados fornecidos numa análise de solo expressam o grau de acidez $(\mathrm{pH})$, a capacidade de troca catiônica (CTC), o teor de matéria orgânica e concentração de nutrientes, funcionando como indicadores do estado químico do solo.

\section{- $\mathrm{pH}$}

$\mathrm{O} \mathrm{pH}$ é um indicador da acidez ativa ou alcalinidade de um solo e conseqüentemente, fornece também informações da sua situação físico-química. Um solo excessivamente ácido, bem como aquele excessivamente alcalino, tem menos oxigênio, menos matéria orgânica, menor capacidade para reter água, menor crescimento das raízes, menor atividade biológica e mais íons tóxicos. Em ambos os casos, o solo sofreu um processo de degradação. Um solo é ácido quando possui muitos íons $\mathrm{H}^{+}$e poucos íons de cálcio $\left(\mathrm{Ca}^{++}\right)$, magnésio $\left(\mathrm{Mg}^{++}\right)$, potássio $\left(\mathrm{K}^{+}\right)$e sódio $\left(\mathrm{Na}^{+}\right)$adsorvidos em seu complexo coloidal, isto é, de troca. O solo alcalino, ao contrário, possui cátions em excesso. (PRIMAVESSI, 1981)

Em termos de nutrição das plantas, a faixa ideal de pH situa-se em torno de 5,6 a 6,2. Dias (1998) afirma que nesta faixa o alumínio (Al) encontra-se precipitado e a maioria dos nutrientes encontra-se em formas solúveis, sendo assim passíveis de serem absorvidos pelas raízes. Recentemente, levantamentos de espécies vegetais com potencial para serem usadas na recuperação de áreas degradadas mostraram 
espécies que toleram valores de $\mathrm{pH}$ na faixa de 4,2 a 5,0. Essas plantas toleram a toxidez de elementos que se disponibilizam nessa faixa.

Os solos ou substratos de uma mineração normalmente passam por alterações físicas extremas, perdem estrutura, diminuem a quantidade de macroporos e de matéria orgânica, aumentam ou diminuem $\circ \mathrm{pH}$ e, disponibilizam elementos que podem tornar-se tóxicos, como o alumínio, manganês, ferro, e outros. A Tabela 2 mostra as variações de $\mathrm{pH}$ em diferentes substratos e solos.

Tabela 2: Valores de $\mathrm{pH}$ de amostras dos diferentes substratos e solos.

\begin{tabular}{|c|c|}
\hline Substrato & pH \\
\hline Substrato remanescente de mineração de ouro ${ }^{1}$ & $\mathbf{1 , 5}$ \\
\hline $\begin{array}{l}\text { Depósito de rejeito de beneficiamento de } \\
\text { bauxita }^{2}\end{array}$ & 4,6 \\
\hline $\begin{array}{l}\text { Depósito de rejeito de beneficiamento de } \\
\text { mineração de ferro }\end{array}$ & 6,3 \\
\hline $\begin{array}{l}\text { Depósito de rejeito de beneficiamento de } \\
\text { mineração de ferro }{ }^{1}\end{array}$ & 8,2 \\
\hline $\begin{array}{l}\text { Substrato remanescente de mineração de } \\
\text { carvão }{ }^{1}\end{array}$ & 1,7 \\
\hline Floresta Estacional Secundária $^{3}$ & $\mathbf{5 , 5}$ \\
\hline $\begin{array}{l}\text { Plantio (15 anos) com } M \text {. scabrella numa área } \\
\text { de mineração de bauxita }\end{array}$ & 4,9 \\
\hline${ }_{\mathrm{MG})^{5}}$ Cerrado (Estação Florestal de Paraopeba - & 4,9 \\
\hline Cerradão (Descalvado, SP) ${ }^{6}$ & 3,6 \\
\hline Depósito de rejeito de mineração de areia $^{6}$ & 3,7 \\
\hline
\end{tabular}

Fonte: (1) Dias,1998; (2) Reis 2006; (3) Almeida, 2002; (4) Nappo, 2000.

(5) Silva Junior et al, 1987; (6) dados obtidos no presente trabalho. 


\section{- Capacidade de troca catiônica (CTC)}

No solo, os colóides orgânicos (húmus) e os colóides inorgânicos (argilas) são os materiais que apresentam atividade superficial e são capazes de adsorver elementos presentes na solução solo. Denomina-se solução solo à água do solo

disponível às plantas, que contém substâncias em forma iônica dissolvidos em solução. Os colóides são partículas que apresentam cargas elétricas principalmente negativas em sua superfície, o que Ihes permite atrair, reter ou trocar elementos com cargas elétricas opostas, ou seja, cátions. Esses, na sua maioria, são nutrientes minerais para as plantas como é o caso do cálcio (Ca), o magnésio $(\mathrm{Mg})$ ou o potássio $(\mathrm{K})$; nesta situação o solo pode ser considerado rico em nutrientes. Quando a ocupação da CTC é na sua maioria de cátions de alumínio ( $\mathrm{Al}$ ) ou hidrogênio $(\mathrm{H})$, considerados potencialmente tóxicos, o solo é caracterizado como pobre em nutrientes. Assim, a CTC é a soma dos elementos minerais adsorvidos em forma de cátions $(\mathrm{K}+\mathrm{Ca}+\mathrm{Mg}$ $+\mathrm{H}+\mathrm{Al}$ ) que o solo pode reter, de forma reversível, e se expressa em milimols de carga por decímetro cúbico $\left(\mathrm{mmolc} \mathrm{dm}^{-3}\right.$ ) (IAC, 1997). O valor dessa capacidade varia com o teor e natureza das argilas, mas principalmente com o teor de húmus, sendo muito importante para a retenção de nutrientes (TROEH; THOMPSOM, 2007), (BRADY; WEIL, 2007).

\section{- Matéria orgânica (MO)}

Matéria orgânica é toda substância morta no solo, seja proveniente de plantas, microrganismos, excreções animais da fauna terrícola ou da própria meso e microfauna morta do solo. A sua presença é de grande importância para que o solo apresente boas características físicas, químicas e biológicas e constitui um componente fundamental da sua capacidade produtiva. Casagrande e Soares (2009), afirmam que muitos atributos do solo têm estreita relação com a matéria orgânica: estabilidade de agregados e da estrutura (agente cimentante), atividade e diversificação biológica, CTC e lixiviação de nutrientes. Solos de áreas tropicais com vegetação natural apresentam um conteúdo estável de 4 a 6\% de matéria orgânica e sua diminuição é um dos principais indicativos de degradação, pois reflete uma 
mudança do estado de equilíbrio do solo em função do manejo. Estes autores asseveram que as perturbações antrópicas de um sistema estável normalmente causam mais perdas do que ganhos de carbono, implicando na redução de seu teor ao longo do tempo, com conseqüente degradação da qualidade do solo no desempenho das suas funções básicas.

Segundo Primavessi (1981), a matéria orgânica fornece substâncias agregantes ao solo, melhorando a sua estrutura e tornando-o mais estável à ação das chuvas. Húmus é a matéria orgânica que passou pelo processo de decomposição e lixiviação de nutrientes e, posteriormente, por um processo de humificação. O processo de decomposição fornece ácidos orgânicos e alcoóis, que servem como fonte de carbono aos microrganismos de vida livre e aos fixadores de nitrogênio, possibilitando a fixação desse elemento. Estes organismos também produzem substâncias de crescimento como triptofano e ácido indol-acético, que possuem efeito muito positivo sobre o desenvolvimento vegetal. As substâncias intermediárias produzidas na decomposição também podem ser absorvidas pelas próprias plantas, aumentando seu crescimento. Uma vez humificada, a matéria orgânica pode aumentar a CTC e aumentar o poder tampão, que é a resistência contra modificações bruscas de $\mathrm{pH}$, especialmente importante para evitar choques violentos na calagem ou na adubação sobre a microvida e evita igualmente desequilíbrios minerais. A matéria orgânica fornece substrato energético, que torna possível a atividade de fungos, bactérias e animais do solo. À medida que os resíduos orgânicos são decompostos, formam-se gel e outros produtos viscosos que, juntamente com bactérias e fungos associados, estimulam a formação de agregados.

Outra característica importante citada por Casagrande e Soares (2009) é que a MO funciona como fonte de nutrientes, principalmente nitrogênio, fósforo, enxofre e micronutrientes, além de diminuir a toxidez de poluentes e elementos tóxicos, como o alumínio em solução.

Primavesi (1981) esclarece que, dos diversos tipos de substâncias orgânicas, somente o húmus consegue influir nas propriedades químicas do solo, enquanto as demais têm maior influência sobre as características físicas do solo. O húmus influencia no acréscimo principalmente da CTC, mas não fornece nutrientes de 
forma significativa. ${ }^{2}$ Estudos mais recentes como os de Corrêa (2007) e Kitamura et al (2008) assinalam também o lodo de esgoto como agente que pode influenciar no aumento da CTC do solo e fornecer nutrientes de forma mais significativa. Casagrande e Soares (2009) apontam que nas regiões tropicais e subtropicais a contribuição de MO no teor de CTC é significativa.

Motta-Neto (1996) apud Reis (2006) cita que, de todas as propriedades de um solo tropical, a quantidade e qualidade de matéria orgânica devem ser as que merecem maior atenção devido ao importante papel por ela desempenhado. À medida que se propiciam aumentos ou manutenção dos teores em níveis aceitáveis, obtêm-se melhorias na capacidade de retenção de umidade, estruturação e porosidade do solo, CTC e fornecimento de nutrientes, incremento da quantidade, diversidade e atividade da biota, além da redução da toxidez de metais pesados e dos efeitos deletérios do alumínio nas plantas sensíveis.

Reis (2006) aponta que a matéria orgânica do solo pode ser utilizada como indicadora da qualidade ou recuperação de solos porque, seu teor é bastante sensível às práticas de manejo, e também porque a matéria orgânica está relacionada com a maioria dos atributos e funções do solo, tais como atividade biológica, estabilidade de agregados estrutura, infiltração e retenção de água, resistência à erosão, CTC e disponibilidade de nutrientes para as plantas. $\mathrm{O}$ autor admite que o teor ideal de matéria orgânica é de $5 \%$, mas que teores de 2 a $3 \%$ são aceitáveis. Corrêa (2006) assevera que substratos minerados apresentam teores de matéria orgânica abaixo de $1 \%$ e aumentar esse valor para cerca de $2 \%$, no mínimo, é essencial para o sucesso de uma revegetação.

A prática de adição de topsoil ou solo superficial nas áreas mineradas é uma maneira de resgatar o conteúdo de MO no substrato acondicionado para ser revegetado. Materiais como turfa, resíduos de plantas, cascas de arroz, cascas de coco, estercos de animais domésticos, a parte orgânica do lixo doméstico, húmus de minhoca, lixo compostado, lodo de esgoto, restos de podas de árvores e outros são considerados fontes de matéria orgânica que podem ser utilizadas para a melhoria de substratos e ações de recuperação ou reconstrução de solos. Na Tabela 3, Corrêa (2007) indica o teor de matéria orgânica de alguns destes materiais, demonstrando seu potencial como possíveis aportes de MO.

\footnotetext{
${ }^{2}$ Informação escrita pelo Professor Dr. Rodrigo Studart Corrêa, docente da Univ. de Brasília.
} 
Tabela 3: Teor de matéria orgânica de diferentes fontes.

\begin{tabular}{|c|c|}
\hline $\begin{array}{c}\text { Fontes de matéria } \\
\text { orgânica }\end{array}$ & $\begin{array}{r}\text { Matéria } \\
\text { orgânica (\%) }\end{array}$ \\
\hline Lodo de esgoto & 61 \\
\hline Composto de lixo & 35 \\
\hline Esterco de bovino & 57 \\
\hline Vermicomposto & 80 \\
\hline Esterco de ave & 65 \\
\hline Serrapilheira & Variável \\
\hline
\end{tabular}

Fonte: Corrêa (2007)

\section{- Nutrientes}

Os elementos minerais que a planta necessita para seu desenvolvimento são chamados nutrientes e estão divididos em macronutrientes e micronutrientes. A diferença se encontra na quantidade de cada um que a planta utiliza para seu desenvolvimento e também na sua disponibilidade dependendo diretamente das condições do solo. Reis Duarte e Casagrande (2006) consideram muito importante a recolocação dos nutrientes que foram perdidos por erosão ou lixiviação com a retirada de vegetação. Ponderam ainda que o fósforo e o cálcio devem receber atenção especial. $\mathrm{O}$ fósforo pelo fato dos solos serem naturalmente pobres deste nutriente e o cálcio porque sua deficiência impede o crescimento do sistema radicular. Conjuntamente com a deficiência de cálcio é comum haver excesso de alumínio em profundidade (após $20 \mathrm{~cm}$ ), impedindo o desenvolvimento do sistema radicular. Com a falta de cálcio e/ou excesso de alumínio em profundidade o sistema radicular desenvolve-se superficialmente, resultando em exploração de um menor volume de solo ocasionando menor absorção de água e nutrientes.

Numa área onde o solo está sendo recuperado, a avaliação do nível de nutrientes serve como indicador da atividade dos microrganismos e dos processos que estão sendo realizados para garantir um abastecimento suficiente, tanto para as plantas como para os organismos do solo. O manejo para a recuperação de solos 
normalmente realiza adubação nos dois primeiros anos, com a intenção de garantir o estabelecimento da vegetação. Subseqüentemente espera-se que o próprio sistema solo-planta forneça os nutrientes mediante a ativação do processo de ciclagem de nutrientes. Nessa situação, a variação temporal nos níveis de nutrientes poderá servir como indicador da recuperação do solo. Num experimento para avaliar o crescimento de espécies vegetais em resposta aos níveis de fertilidade numa revegetação de tanques de rejeito de bauxita, Dias et al. (2008) encontraram que as espécies responderam positivamente aos níveis de fertilidade criados pelas adubações. Contudo, comparando as avaliações realizadas aos 36 e 48 meses com a que foi feita aos sessenta meses, foi observado que as espécies vêm apresentando baixos valores de incremento de altura e diâmetro de colo. A caracterização química indicou que não há efeito residual das adubações realizadas, não existindo diferenças significativas na disponibilidade de nutrientes, teores de matéria orgânica e valores de pH entre os níveis de adubação. Concluíram que os níveis de adubação aplicados aos vinte meses, após o plantio, foram insuficientes para garantir que as espécies apresentem seu potencial de fixação de carbono (acúmulo de biomassa) e, possivelmente, a sustentabilidade do sistema.

Numa caracterização físico-química do solo feita por Melo (2007) em áreas mineradas pela extração de cassiterita na Região Amazônica, se constataram diferenças significativas nos teores médios de matéria orgânica e de potássio $\left(K_{+}\right)$ entre a mata e a capoeira em relação às diferentes situações degradadas (lavra e rejeito). Quanto à densidade de solo e de partículas, também houve diferenças significativas entre a mata e a capoeira em relação às situações de degradação. Num estudo similar da recuperação de solos degradados pela extração de petróleo e gás feito por Teixeira et al. (2008), a caracterização química do solo foi feita a cada $20 \mathrm{~cm}$ até a profundidade de $60 \mathrm{~cm}$. Os teores de $\mathrm{C}$ foram menores que os da floresta, principalmente na camada de 0 a $20 \mathrm{~cm}$. Os resultados de $\mathrm{pH}$, cálcio, fósforo e potássio foram superiores na área em recuperação, demonstrando o efeito da calagem e da adubação realizada com o propósito de favorecer a vegetação implantada. Conforme Primavesi (1981), o fósforo disponível na camada superficial do solo reduz-se drasticamente com o tempo, após atividades agrícolas. A mineração, embora seja uma atividade diferente da agrícola, requer a supressão de vegetação e da camada superficial de solo original, podendo promover sensível diminuição nos teores de fósforo na camada superficial de solo/substrato a ser 
recuperado, uma vez que o fósforo orgânico está associado à presença de matéria orgânica.

Há outros indicadores de solo que podem ser aplicados para a avaliação da revegetação de áreas degradadas tais como a cor do solo/substrato, a perda de solo (erosão), o teor de nitrogênio, o índice metabólico, a atividade microbiana, a biomassa microbiana, a resistência à penetração das raízes, a estrutura, a taxa de infiltração de água, etc. A utilização vai depender do conhecimento e recursos de que dispõe o avaliador para determinar os métodos de coleta, os procedimentos de análise ou determinação de dados, assim como a maneira correta de interpretar os resultados. Outro aspecto a ser contemplado é que os dados resultem significativos e passíveis de compreensão pelos interessados. 


\section{CAPÍTULO 2}

\section{METODOLOGIA PROPOSTA PARA A PESQUISA}

O monitoramento de áreas mineradas revegetadas é fundamental no processo de recuperação e deve considerar o acompanhamento do estado do substrato da vegetação implantada. Uma avaliação do desempenho da revegetação com base somente na observação do estado geral das plantas e do acompanhamento dos seus parâmetros é insuficiente quando as condições edáficas se apresentam como fator limitante para o seu desenvolvimento. Este fato é o motivador desta proposição do monitoramento do substrato das áreas mineradas como complemento da avaliação do local revegetado. O método utiliza a medição de parâmetros e gera indicadores numéricos do estado geral do substrato oferecendo amplo subsídio para uma apreciação mais clara e completa do conjunto. Salienta-se que os parâmetros escolhidos são amplamente conhecidos e difundidos para o estudo da qualidade de solos, e que o método busca adaptar os procedimentos e as técnicas usuais de investigação agrícola do solo à situação dos solos minerados.

A metodologia proposta fundamenta-se na observação e no acompanhamento da evolução das características físico-químicas do substrato acondicionado para revegetação das áreas em recuperação e envolve uma descrição detalhada das possíveis atividades e tarefas destinadas para este fim. Uma vez que o substrato acondicionado na área é incumbido de tornar-se o sustentáculo da vegetação implantada, é pertinente avaliar suas condições como suporte que irá oferecer às plantas. O desenvolvimento das plantas também precisa ser acompanhado de maneira que possam se associar ambas as evoluções.

Os procedimentos e as atividades que compõem a metodologia proposta estão divididos basicamente em: estudos de gabinete que possibilitam conhecer o histórico do local; os trabalhos de campo para a coleta das amostras e dados de vegetação; as determinações laboratoriais que irão gerar os dados numéricos do substrato; e a análise e interpretação dos resultados com estabelecimento dos indicadores de desempenho para as áreas investigadas. 


\subsection{Trabalhos de gabinete}

A avaliação das condições do substrato de uma área revegetada requer um estudo prévio de todas as ações de manejo praticadas, de maneira a compor um quadro geral das configurações presentes no campo. Destacam-se o conhecimento do tipo de mineração praticado e os impactos ambientais decorrentes, a caracterização da degradação gerada, o histórico das atividades de recuperação efetuadas, com as metas estabelecidas e as datas de realização, entre outros aspectos. É preciso recorrer a diferentes fontes de informação, sejam formais ou informais. Constituem fontes formais: os estudos de impacto ambiental (EIAs), os relatórios de impacto ambiental (RIMAs), os planos de recuperação de áreas degradadas (PRADs), os planos de controle ambiental (PCAs), os relatórios de monitoramento, os relatórios de lavra, os termos de ajuste de conduta (TACs), registros de pesquisas científicas eventualmente realizadas no local, etc. As fontes informais são as entrevistas com pessoal encarregado da atividade, com o pessoal das firmas terceirizadas envolvidas no processo, com técnicos dos órgãos ambientais, depoimentos de empregados mais antigos, de moradores do entorno ou da circunvizinhança, informações de periódicos, ...etc.

\subsection{Trabalhos de campo}

Os trabalhos de campo compreendem fundamentalmente o reconhecimento preliminar do local em estudo, as amostragens do substrato e as observações da vegetação. Em primeiro lugar é preciso familiarizar-se com os locais de estudo e seu entorno, visando estabelecer as melhores condições para a coleta das amostras do substrato e a captação dos dados da vegetação, tendo-se em conta que a amostragem deve ser suficientemente representativa das condições do local como um todo. Deve-se também estabelecer locais de referência que possibilitem comparações elucidativas e facilitem as avaliações. 


\subsubsection{Reconhecimento preliminar do local do estudo}

Trata-se da familiarização com o ambiente a ser investigado permitindo estabelecer as melhores condições de coleta de dados, tanto do substrato como da vegetação. As visitas in situ têm o propósito de observar as condições de cada área do local de estudo, particularmente quanto ao grau de desenvolvimento da vegetação e sua relação com o tempo de implantação, bem como a identificação das possíveis dificuldades ou impedimentos no desenvolvimento normal da vegetação. Fatores de degradação persistentes ou gerados mais recentemente como trânsito de gado, eventuais queimadas, focos de perda de material do substrato por erosão, presença de plantas invasoras exóticas ou nativas de outras regiões ou biomas, etc. devem ser conferidos.

Nas condições das áreas em estudo, a identificação da homogeneidade é importante, tanto no tipo de plantio, como no tratamento do substrato para estabelecer as áreas representativas das amostragens. Para efeito de comparação, estágios iniciais e avançados de revegetação são desejáveis, e também áreas de referência contendo vegetação nativa ou com estágio avançado de regeneração. Outra configuração de referência é aquela área que sofreu alteração pela mineração e já tem o substrato preparado para o plantio, mas que ainda não tenha sido revegetada.

Conjuntamente com o histórico do local, todos estes fatores comentados determinarão o delineamento dos planos de amostragem e seu grau de representatividade.

\subsubsection{Amostragem do substrato}

A comparação das características do substrato de uma área sem revegetação e as de uma área com determinado tempo de revegetação é a base das observações, proporcionando a noção do grau de desenvolvimento vinculado à recuperação do substrato. Uma alternativa é a comparação do substrato das áreas revegetadas com solos de áreas tidas como referência, seja com vegetação nativa formada ou em estado avançado de regeneração. 
O procedimento recomendado é a abertura de trincheiras nas áreas selecionadas para avaliação, onde serão extraídas amostras de substrato em camadas pré-estabelecidas. O número de trincheiras será determinado considerando a homogeneidade da área e as ações de manejo nela realizadas, de maneira que o plano de amostragem seja representativo de seu estado geral nas análises posteriores. Além da retirada de amostras, no perfil da trincheira também é importante observar-se as diferentes camadas existentes, distinguidas pela cor, profundidade, presença de raízes, altura da serrapilhiera, etc. Faz-se necessário tomar certos cuidados com a escolha do local e com a própria atividade de abertura, de maneira a não pisotear um dos lados da trincheira e também levar toda a terra cavada sempre para o lado oposto, facilitando a obtenção de amostras e a captação de registros fotográficos do lado preservado.

Quanto à dimensão da trincheira, deve ser capaz de permitir as tarefas de escavação e retirada da terra por uma pessoa. Isto é possível com 1,5 m de comprimento e $1 \mathrm{~m}$ de largura, aproximadamente. A profundidade, vai depender do número de camadas estabelecidas para observação e da soma das suas respectivas espessuras. Em locais minerados, as características do substrato e a disposição dos seus componentes podem não estar bem definidos, incorrendo na necessidade de maior profundidade das trincheiras. Caso contrário, a camada observada poderá ser determinada com base na profundidade média das raízes.

\subsubsection{Amostras indeformadas}

As amostras indeformadas são utilizadas para a determinação de densidade e porosidade do solo. Embora seja uma técnica muito aplicada em agronomia, ela pode ser adaptada para os propósitos de caracterização física dos substratos. Propõe-se a utilização de um trado amostrador (Foto 1), com coleta de amostras do substrato em cilindros de volume conhecido. O equipamento é utilizado para análises físicas do solo, como densidades, porosidades e curvas de retenção. 

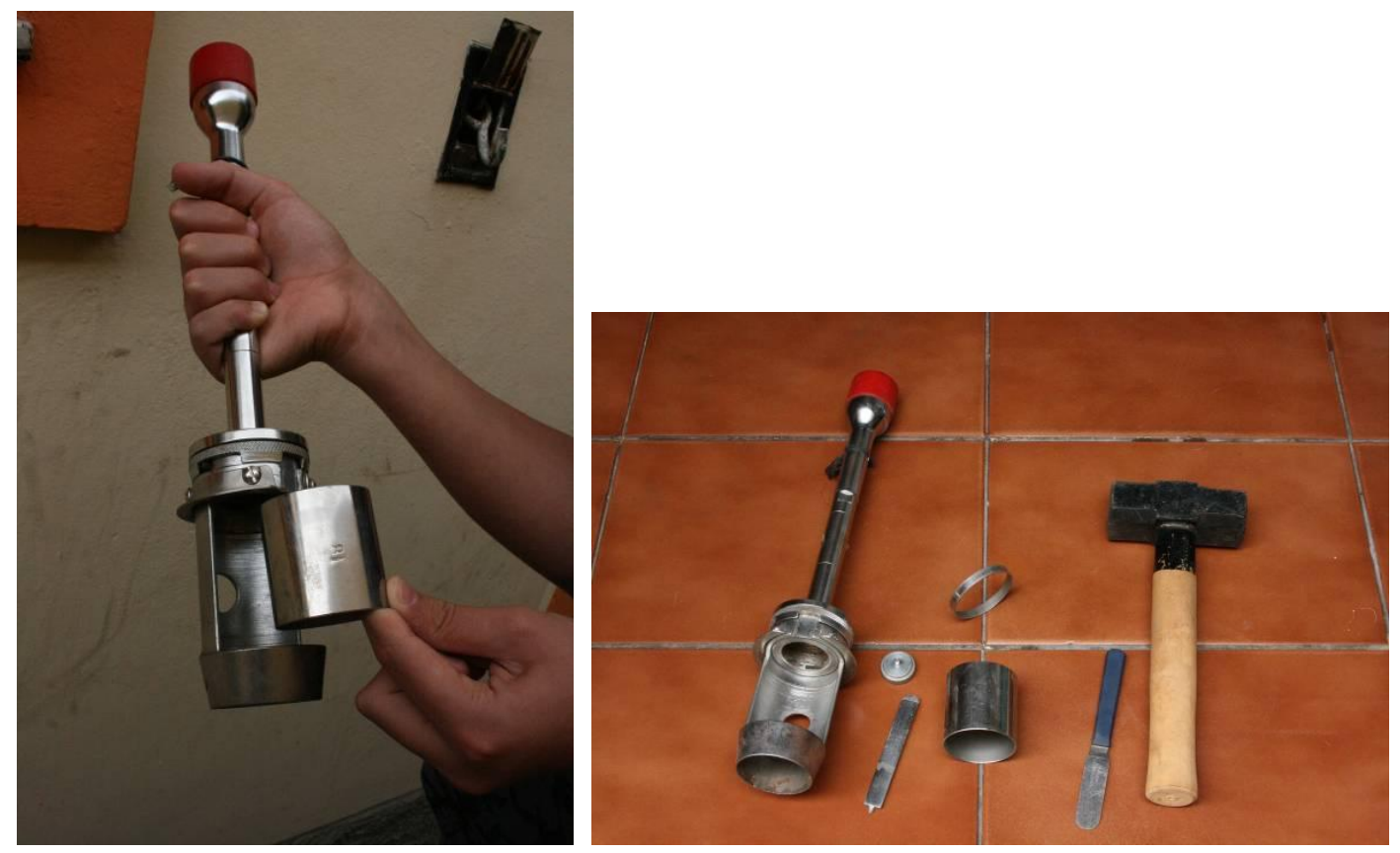

Foto 1: Kit básico do trado amostrador. Destaque para o trado e o cilindro.

A obtenção das amostras consiste em inserir e fixar o cilindro de aço no trado amostrador. Em seguida, crava-se o trado, com o cilindro já inserido, na parede do perfil ou no próprio solo, por impulsos de percussão (pancadas de marreta) até a marca conhecida (Foto 2). Após a remoção do trado, o cilindro é retirado removendo-se o excesso de terra, com o auxílio de uma espátula fina, até igualar as bordas do anel para ajustar o volume do solo com o volume do cilindro (Foto 3). 

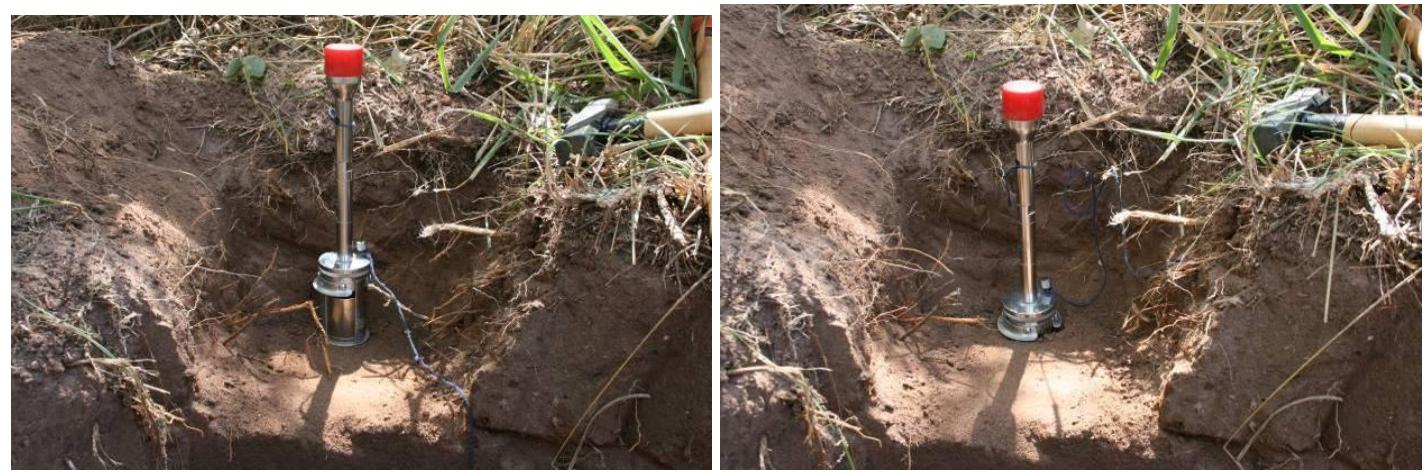

Foto 2: Sequência de amostragem a $20 \mathrm{~cm}$ de profundidade.

Uma vez obtida a amostra, esta é envolvida em filme plástico de PVC para conservá-la e evitar que se desmorone (Foto 3). Nos casos em que o solo está com consistência muito solta e/ou seca, superfície a ser amostrada deve ser previamente umedecida, criando uma adesão entre as partículas de solo e evitando o desmoronamento.
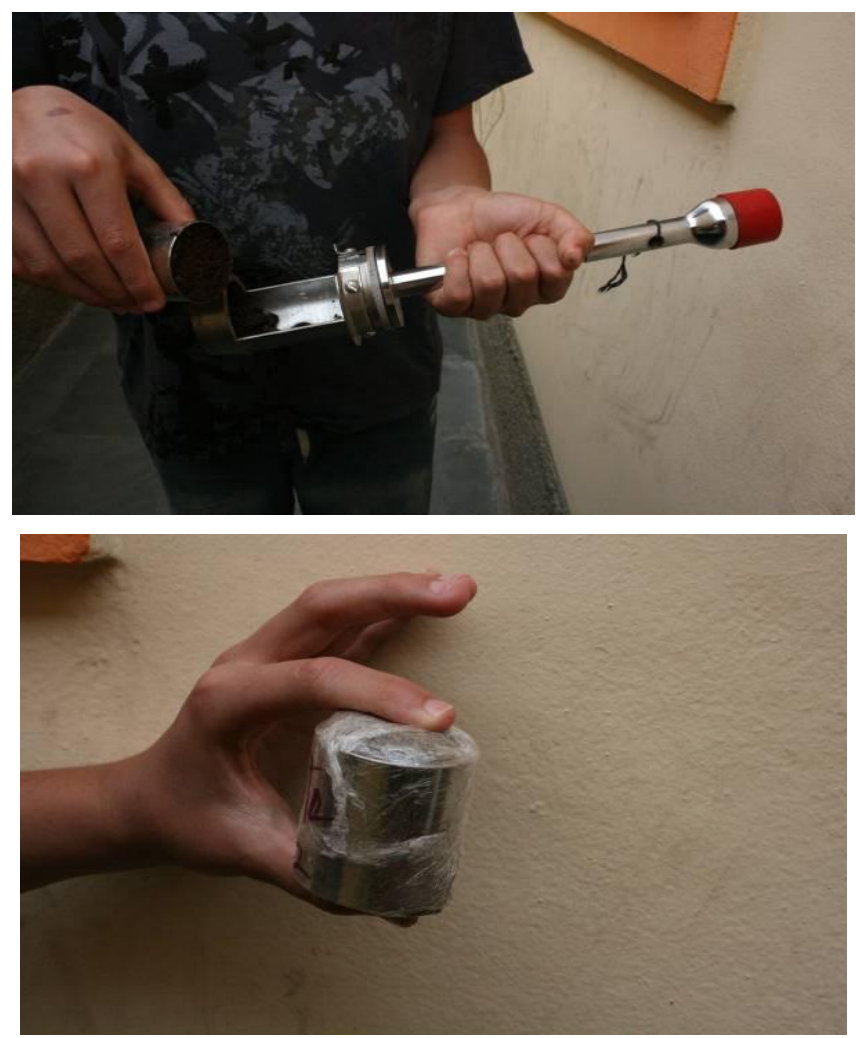

Foto 3: Obtenção da amostra indeformada e acondicionada para garantir sua preservação (conjunto). 


\subsubsection{Amostras deformadas}

As amostras deformadas referem-se àquelas que não precisam ter seu volume preservado. Este tipo de amostras é utilizado para determinações químicas ou granulométricas. Para cada um destes casos é necessário aproximadamente 0,5 $\mathrm{kg}$ de substrato em cada amostra. Quando a coleta da amostra indeformada é na superfície deve-se proceder à retirada de galhos, pedras e restos de plantas.

\subsubsection{Avaliação do estado geral da vegetação arbórea}

As observações da vegetação permitem avaliar o estado de desenvolvimento das espécies arbóreas. Em geral, o crescimento das mudas é a variável mais utilizada com este propósito. Quando as mudas atingem certa idade começam a formar lenho e engrossar o tronco, sendo que, indivíduos arbóreos mais velhos têm uma circunferência do tronco maior. Na avaliação do estado da vegetação se propõe levantar dados sobre a altura e a circunferência à altura do peito (CAP) das árvores implantadas. Estas duas variáveis foram escolhidas pela simplicidade na sua determinação e porque refletem eficientemente as condições em que se encontram os indivíduos plantados. Posteriormente estas informações poderão ser utilizadas para relacioná-las com as características físico-químicas do substrato, no intuito de compreender as conexões que influenciam o desenvolvimento.

Uma variável complementar para a investigação pode ser a diversidade de espécies. A intenção é conhecer a composição das espécies arbóreas que foram usadas no plantio ou conferir a veracidade das informações obtidas sobre este quesito. Uma informação adicional é sobre possíveis espécies que não se adaptaram às condições do local ou aquelas que estejam surgindo espontaneamente. Este fato merece atenção especial, pois reflete a existência de mecanismos de regeneração natural como a produção de sementes das espécies implantadas, a chegada de propágulos por algum mecanismo de dispersão, a formação de banco de sementes, entre outros. A regeneração natural está estreitamente ligada com o conceito de auto-sustentabilidade que se busca alcançar para que as áreas revegetadas sejam consideradas recuperadas. 
Para o levantamento dos dados sugere-se 0 método de parcelas representativas (RODRIGUES, 1989) amplamente difundido e já utilizado por Almeida (2002) e Almeida et al. (2007). Consiste na delimitação da área amostral, com a sua instalação de forma aleatória visando representar toda a área de plantio. O levantamento deve ser conduzido seguindo os princípios básicos da experimentação, casualização e repetição, tal como comentado em Almeida (2002). Mais recentemente, Barbosa et al. (2009) apresentam uma proposta de utilização de parcelas representativas para o levantamento de dados de reflorestamentos que também pode ser aplicada. Brancalion et al. (2009) propõem o levantamento de dados e a avaliação da vegetação cujos princípios podem ser adaptados para trabalhos de investigação de áreas revegetadas de mineração.

As variáveis de vegetação propostas para a investigação são:

$\checkmark$ Altura de planta (m).

$\checkmark$ Circunferência na altura do peito (CAP) (cm): Variável que corresponde às medidas da circunferência do tronco das espécies arbóreas, realizadas a uma altura padronizada (altura do peito de aproximadamente $1,30 \mathrm{~m}$ do solo).

\subsection{Ensaios de laboratório}

As amostras obtidas do substrato e do solo poderão ser submetidas às determinações descritas nos itens subseqüentes, resultando nas variáveis do substrato propostas para a pesquisa.

\subsubsection{Densidade de solo (Ds)}

A densidade do solo, também denominada densidade aparente, densidade de volume ou massa epecífica aparente é definida como a relação entre massa de uma amostra de solo seca e a soma dos volumes ocupados pelas partículas sólidas e poros (vazios). 


\section{Densidade de solo $=\frac{\text { Massa seca dos sólidos }(\mathrm{g})}{\text { Volume de solo+volume de poros }\left(\mathrm{cm}^{3}\right)}$}

A norma NBR 9813 (ABNT, 1987) prescreve a determinação de densidade aparente mediante o método do cilindro. Em consulta realizada ao Laboratório de Solos do IPT, essa norma é a base para a determinação de densidade de solo, sendo utilizada como padrão para ensaios de rotina, e será adotada nesta pesquisa.

O método fundamenta-se na obtenção de dois valores principais: a massa e o volume de solo obtidos no cilindro volumétrico (amostra indeformada). A massa seca é obtida pesando-se o material do cilindro seco em estufa, na faixa de $105^{\circ} \mathrm{C}$ a $110{ }^{\circ} \mathrm{C}$. Para a determinação do volume utiliza-se a equação:

$$
\mathrm{Vc}=\pi\left(\frac{D^{2}}{4}\right) \mathbf{H c}
$$

$$
\begin{array}{r}
\text { Sendo: } \mathrm{Vc}=\text { volume do cilindro }\left(\mathrm{cm}^{3}\right) \\
\mathrm{D}=\text { diâmetro do cilindro }(\mathrm{cm}) \\
\mathrm{Hc}=\text { altura do cilindro }(\mathrm{cm})
\end{array}
$$

\subsubsection{Granulometria}

A textura do solo é definida como a proporção relativa dos diferentes grupos de partículas minerais primárias que o constituem: a areia (com diâmetro de 2,0 a $0,05 \mathrm{~mm})$, o silte $(0,05-0,002 \mathrm{~mm})$ e a argila $(<0,002 \mathrm{~mm})$. Sua determinação se da pela análise granulométrica. Uma classificação simples de textura de solos (Brady \& Weil, 2007) estabelece 3 classes texturais básicas:

- Arenosa (argila < 15\%);

- Média (argila entre 15 - 35\%);

- Argilosa (argila > 35\%). 
A textura é considerada uma propriedade básica do solo, pois não está sujeita a mudanças rápidas. Sua determinação pode ser considerada uma informação técnica importante, pois fornece diagnóstico geral da resistência à erosão e quanto à sua fertilidade.

A granulometria do solo é determinada segundo a norma NBR 7181 (ABNT, 1987) realizada por uma combinação de peneiramento e sedimentação, seguindose as normas de rotina de ensaio definidas pelo Laboratório de Solos da Engenharia Civil da EPUSP. A norma NBR 6457 (ABNT, 1986) é usada para a preparação das amostras.

\subsubsection{Densidade de partículas (Dp)}

Denominada também como densidade real, densidade de sólidos, peso específico real, peso do volume de sólidos ou massa específica real, é a relação existente entre a massa de uma amostra de solo e o volume ocupado pelas suas partículas sólidas. Nos solos, seu valor varia entre 2,30 Mg.m ${ }^{-3}$ e 2,90 Mg.m ${ }^{-3}$. O valor médio, para efeito de cálculo, é de $2,65 \mathrm{Mg}^{-3} \mathrm{~m}^{-3}$ (Kiehl, 1979), isto porque os constituintes minerais predominantes nos solos são o quartzo, os feldspatos e os silicatos de alumínio coloidais, cujas densidades reais estão em torno de 2,65 Mg.m ${ }^{3}$. Oliveira \& Espinosa apud Kiehl (1979), a partir de dados periódicos da Embrapa, obtiveram valores médios gerais para a Dp como sendo 2,59 $\mathrm{Mg} \cdot \mathrm{m}^{-3}$ e $2,84 \mathrm{Mg} \cdot \mathrm{m}^{-3}$ em latossolos roxos, de 2,70 Mg.m $\mathrm{m}^{-3}$ em terra roxa e de $1,89 \mathrm{Mg} \cdot \mathrm{m}^{-3} \mathrm{em}$ solos orgânicos.

A norma NBR 6508 (ABNT, 1984) prescreve o método de determinação de massa específica dos grãos (Dp) de solos que passam pela peneira de $4,8 \mathrm{~mm}$, por meio de picnômetro e será a base para a determinação deste parâmetro na pesquisa, estando de acordo com o padrão de ensaios de rotina utilizado no Laboratório de Mecânica de Solos da Escola Politécnica da USP. 


\subsubsection{Porosidade total}

Denominado também como espaço poroso, volume de poros totais, volume de porosidade, volume de poros, espaço lacunar, espaço intersticial do solo ou índice de vazios. O arranjo ou a geometria das partículas do solo determina a quantidade e a natureza dos poros de um solo. A porosidade depende principalmente da textura, da estrutura e da matéria orgânica presente nos solos. Pode ser definida como a relação entre o volume de vazios ou o espaço do solo não ocupado pelos componentes sólidos e o volume total. Para sua determinação é usada a expressão:

$$
\begin{aligned}
& \text { Porosidade total }(\%)=\left(\frac{1-D s}{D p}\right) \times 100 \\
& \text { Onde: } \quad D s=\text { Densidade de solo } \\
& D p=\text { Densidade de partícula }
\end{aligned}
$$

\subsubsection{Determinação dos parâmetros químicos}

Esta determinação ocorre pela análise química da terra para fins de avaliação da fertilidade, cujos ensaios podem ser realizados em Laboratórios de Fertilidade de Solo e são muito comuns em qualquer localidade onde se pratique agricultura. A análise utiliza os métodos do Manual de Análise do Instituto Agronômico de Campinas IAC (Raij et al., 2001). Previamente à determinação, a amostra de solo deve ser preparada para análise, o que ocorre mediante a secagem, homogeneização e peneiramento na malha $2 \mathrm{~mm}$.

Os métodos sugeridos a seguir, para a determinação de cada uma das características químicas, têm como referência procedimentos que são adotados pelo Laboratório de Análise de Solos da ESALQ-USP. 


\section{$\checkmark$ pH em $\mathrm{CaCl}_{2}$ (acidez trocável) - Método: $\mathrm{CaCl}_{2}$ 0,01 mol.L ${ }^{-1}$}

Princípio do método: medida da atividade de hidrogênio com eletrodo combinado de vidro e referência, na suspensão de terra em $\mathrm{CaCl}_{2}$ 0,01 mol. $\mathrm{L}^{-1}$, na proporção de $1: 2,5$.

\section{$\checkmark$ Matéria orgânica $\left(\mathrm{g} \cdot \mathrm{dm}^{-3}\right)$ - Método: Colorimétrico}

Princípio do método: a determinação da quantidade de matéria orgânica em solos baseia-se na sua oxidação a $\mathrm{CO}_{2}$ por íons dicromato, em meio fortemente ácido. Determina-se a quantidade de íons $\mathrm{Cr}(\mathrm{III})$ por colorimetria, medindo-se a intensidade da cor esverdeada produzida por esses íons em solução. A determinação por colorimetria, requer a montagem de uma curva padrão de calibração, que relaciona as quantidades de matéria orgânica e a absorbância do extrato preparado com dicromato de sódio e ácido sulfúrico.

\section{$\checkmark$ H+Al (mmolc.dm $\left.{ }^{-3}\right)$ (acidez potencial) - Método: pH SMP}

Princípio do método: a acidez da amostra de solo em contato com a solução tampão SMP provoca um decréscimo do valor original do $\mathrm{pH}$ da solução $(7,5)$, quando titulada potenciometricamente com ácido forte. A correlação destes valores com aqueles obtidos pelo método do CaOAc $1 \mathrm{~N}$ (estudo de correlação) permite obter os valores de acidez potencial da amostra.

\section{$\checkmark$ Alumínio trocável (mmolc. $\mathrm{dm}^{-3}$ ) - Método: Titulometria (1 mol.L $\mathrm{m}^{-1}$ )}

Princípio do método: a solução de $\mathrm{KCl} 1 \mathrm{~mol} / \mathrm{l}$, por ser um sal neutro, possui a capacidade de extrair apenas cátions ligados eletrostaticamente aos colóides do solo (cátions trocáveis). Assim, esta solução é utilizada para extração de Al trocável,

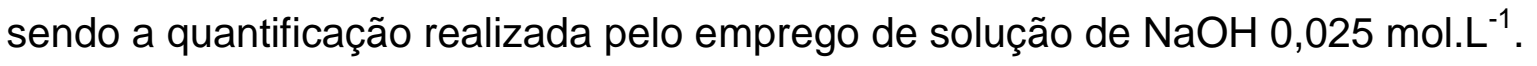

$\checkmark$ Fósforo $\left(\mathrm{mg}_{\mathrm{dm}}{ }^{3}\right)$, Potássio, Cálcio e Magnésio (mmolc.dm- ${ }^{3}$ ) - Método: Resina trocadora de íons

Princípio do método: a extração dos teores "disponíveis" de P, K, Ca e Mg de 
amostras de terra é feita com uma mistura de resinas (catiônica e aniônica) trocadoras de íons, saturadas com bicarbonato de sódio. Após o processo de extração, a resina é passada em solução de $\mathrm{NaCl}\left(1 \mathrm{~mol} . \mathrm{L}^{-1}\right.$ e $\mathrm{HCl}\left(0,1 \mathrm{~mol} . \mathrm{L}^{-1}\right)$ para uma solução de $\mathrm{NH}_{4} \mathrm{Cl}\left(0,8\right.$ mol.L-1 e $\mathrm{HCl}\left(0,2 \mathrm{~mol}^{-L^{-1}}\right)$. A quantificação do fósforo é realizada por colorimetria; a do potássio por fotometria de chama; e a dos íons de cálcio e magnésio por espectrofotometria de absorção atômica.

\section{Outros parâmetros calculados}

$\checkmark$ Soma de bases ( SB ) $\left(\right.$ mmolc. $\left.\mathrm{dm}^{-3}\right)$ :

$$
\mathrm{SB}=(\text { Potássio + Cálcio + Magnésio })
$$

$\checkmark$ Capacidade de troca catiônica ( CTC) $\left(\mathrm{mmolc}^{-\mathrm{dm}^{-3}}\right)$ :

$$
\mathrm{CTC}=(\mathrm{SB}+\text { Alumínio }+ \text { Hidrogênio })
$$

$\checkmark$ Porcentagem de saturação de bases ( V ) (\%):

$$
\mathrm{V}(\%)=\left(\frac{S B}{C T C}\right) \times 100
$$

\subsection{Análise dos dados}

Os dados obtidos com a mensuração periódica dos atributos do substrato permitirão comparar os resultados no decorrer do tempo. Exigências mínimas (para cada parâmetro) estabelecidas com anterioridade ou baseadas em referências bibliográficas podem auxiliar no diagnóstico, conferindo-se assim as melhorias do parâmetro em questão. Este exercício deverá ser realizado também com os parâmetros da vegetação, permitindo uma ilação com os dados do substrato e relacionando resultados. A continuidade destas ações no tempo determina o monitoramento.

A avaliação da área revegetada requer uma apreciação sobre seu estado atual e o monitoramento constitui a ferramenta principal dessa prática, desde que 
forneça elementos concretos baseado em números e não em opiniões pessoais ou idéias subjetivas. Desta forma é possível concluir sobre a evolução do conjunto (substrato e plantas) e quais fatores estão sendo mais determinantes no desenvolvimento da vegetação. As variáveis do substrato que não estão evoluindo, possivelmente, constituem fatores limitantes ao processo de melhoria, sendo necessário aplicações corretivas. $O$ retrato atualizado da área revegetada também permite a comparação direta com áreas de referência, bem como a análise de possíveis trajetórias de comportamento.

Os parâmetros do substrato que melhor forneçam as informações sobre o estado da revegetação e a sua evolução, vinculados às ações realizadas e tempo de revegetação, serão selecionados como indicadores efetivos de desempenho ambiental do local.

Como um recurso complementar para a visualização e comparação dos resultados pode-se fazer uso de análises estatísticas descritivas e inferenciais. A análise descritiva utiliza elementos como medidas resumo (médias, medianas, valore mínimos, valores máximos, desvios padrão, coeficientes de variabilidade, etc.), boxplots, gráficos de perfis, de barras e outros para estabelecer tendências no comportamento das variáveis.

A análise inferencial é realizada de acordo com os interesses da pesquisa. É um trabalho mais aprofundado e especializado que deve ser utilizado em casos de necessidade de um maior rigor científico, quando é preciso confirmar projeções, suposições ou tendências, certificar resultados, estabelecer correlações entre variáveis, aplicar regressão, etc. 


\section{CAPİTULO 3}

\section{ESTUDO DE CASO}

A metodologia proposta foi aplicada para um estudo de caso. Uma cronosseqüência de revegetações praticada pela Mineração Descalvado, a qual permitiu simular um seguimento da evolução da qualidade do substrato e do desenvolvimento da vegetação por um período de 14 anos. O propósito é verificar e comprovar a aplicabilidade do método, obtendo-se conclusões sobre o estado das revegetações a partir da avaliação das informações obtidas do substrato e do estado geral das plantas. Adicionalmente, espera-se determinar quais fatores são os mais influentes no desempenho da vegetação implantada. As rotinas do método, embora muito utilizadas em agricultura, foram adaptadas aos propósitos da avaliação das áreas revegetadas da mineração.

\section{1 Área de estudo}

A Descalvado iniciou suas operações na década de 80 por intermédio da Sandspar Minérios. Atualmente pertence à Companhia O-I, Owens Illinois do Brasil, empresa que fornece areia para a indústria vidreira e de fundição. Como subproduto, a mineração vende areia grossa e pedregulho para a indústria da construção civil.

\subsubsection{Localização e acesso}

Situa-se no Município de Descalvado, a $4 \mathrm{~km}$ ao oeste da cidade de Descalvado, distante $250 \mathrm{~km}$ da capital paulista. As coordenadas centrais de localização da mina, conforme projeção Universal Transversa de Mercator (UTM) corresponde a 7.570,206 km N e 229,241 km E. A área total da mineração compreende $232 \mathrm{ha}$, abrangendo um raio de aproximadamente $2 \mathrm{~km}$ a partir destas coordenadas. O acesso à área, desde a cidade de São Paulo, pode ser realizado 
pela Rodovia Anhanguera (SP 330), até a saída para Descalvado, localizada no Km 227, acessando a Rodovia Doutor Paulo Lauro (SP 215).

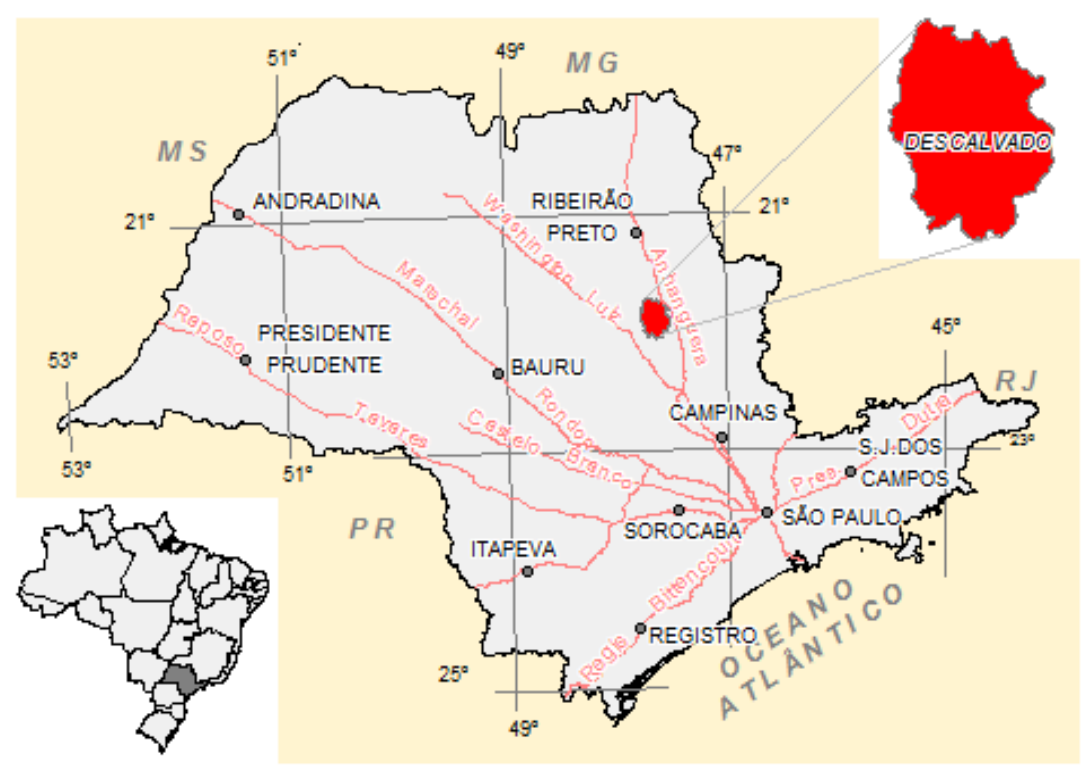

Figura 1: Localização da Mineração Descalvado.

Conforme se visualiza na Foto 4, o terreno da mineração está circundado por uma área com remanescente de mata nativa. Outra mineração de areia vidreira, a Mineração Jundu é vizinha da Mineração Descalvado (lado direito da mineração na Foto 4). 


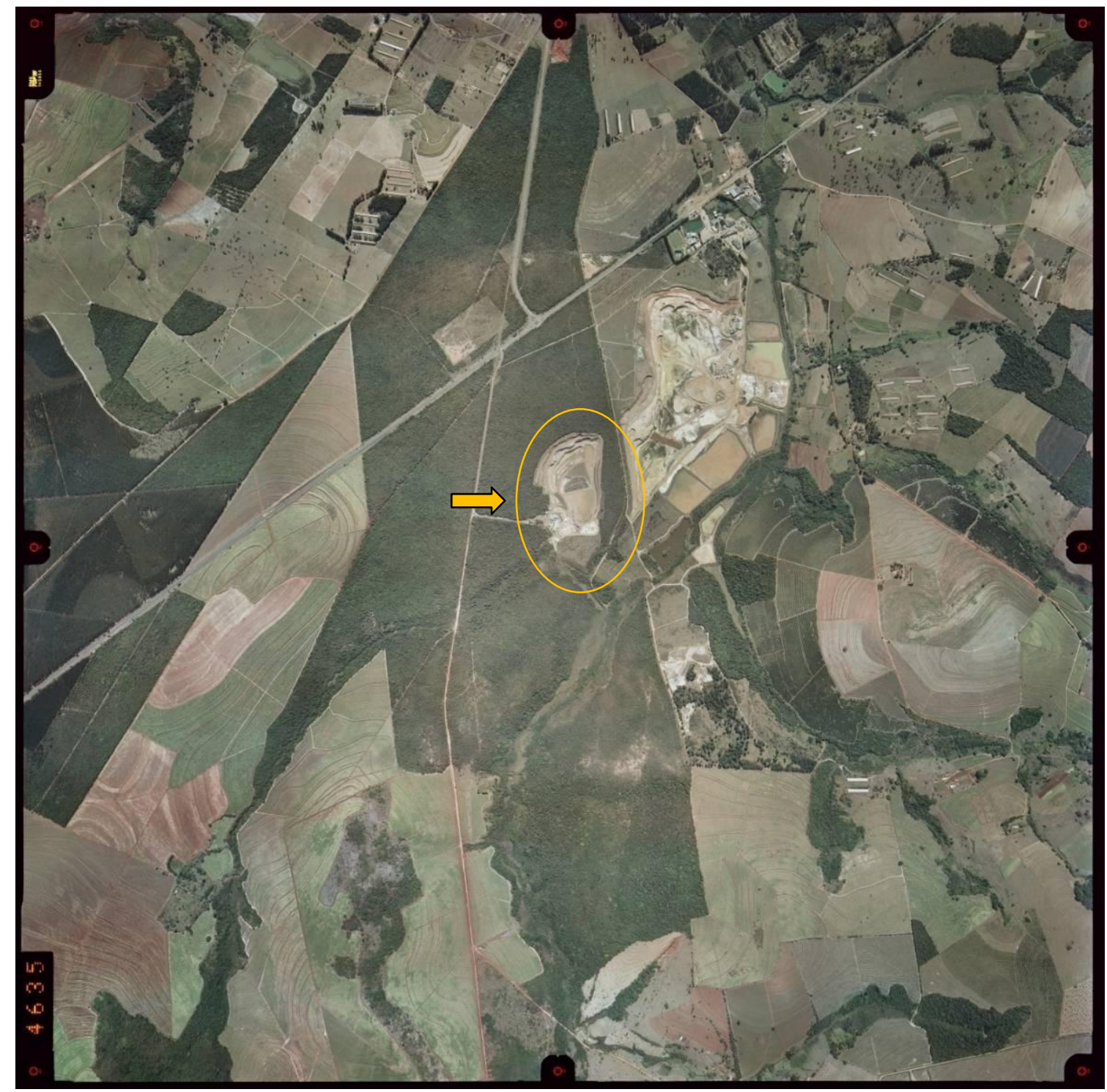

Fonte: Mineração Descalvado

Foto 4: Foto aérea (2006) da Mineração Descalvado e a circunvizinhança.

\subsubsection{Caracterização ambiental da área}

Esta seção apresenta uma breve caracterização ambiental da área e foi fundamentada em: Estudos de Impacto Ambiental (EIAs) da mineração (PA BRASIL, 2008; Alves, 1990), fotos aéreas do ano 2007 fornecidas pela gerencia da empresa e nas visitas realizadas no decorrer da pesquisa. 


\subsubsection{Clima}

A região, situada no centro do Estado, está incluída no clima "Cwa", segundo a classificação de Koeppen. É um clima tropical com estação seca no meio do ano e uma estação de chuvas no final e no início do ano. A precipitação anual média é de 1.500 a $2.000 \mathrm{~mm}$ com chuvas do tipo frontal, abundantes e violentas. As temperaturas variam entre 5 e $32{ }^{\circ} \mathrm{C}$, com uma média de $24^{\circ} \mathrm{C}$; as mais altas são registradas no fim do ano, enquanto as mais baixas no meio do ano. $A$ umidade relativa média do ar está entre 20 e $30 \%$.

Segundo Sentelhas et al. (1998), conforme pode ser observado na Figura 2, na localidade de Descalvado, as chuvas concentram-se entre outubro e abril, com alturas médias entre 120 e 250 mm mensais. Dezembro, Janeiro e Fevereiro são os meses mais chuvosos (precipitação superior a $200 \mathrm{~mm}$ mensais). O período entre abril e setembro é o menos chuvoso (precipitação inferior a $50 \mathrm{~mm}$ mensais). Durante esses meses os valores de evapotranspiração real e potencial são maiores que os de precipitação, ocorrendo déficit hídrico.

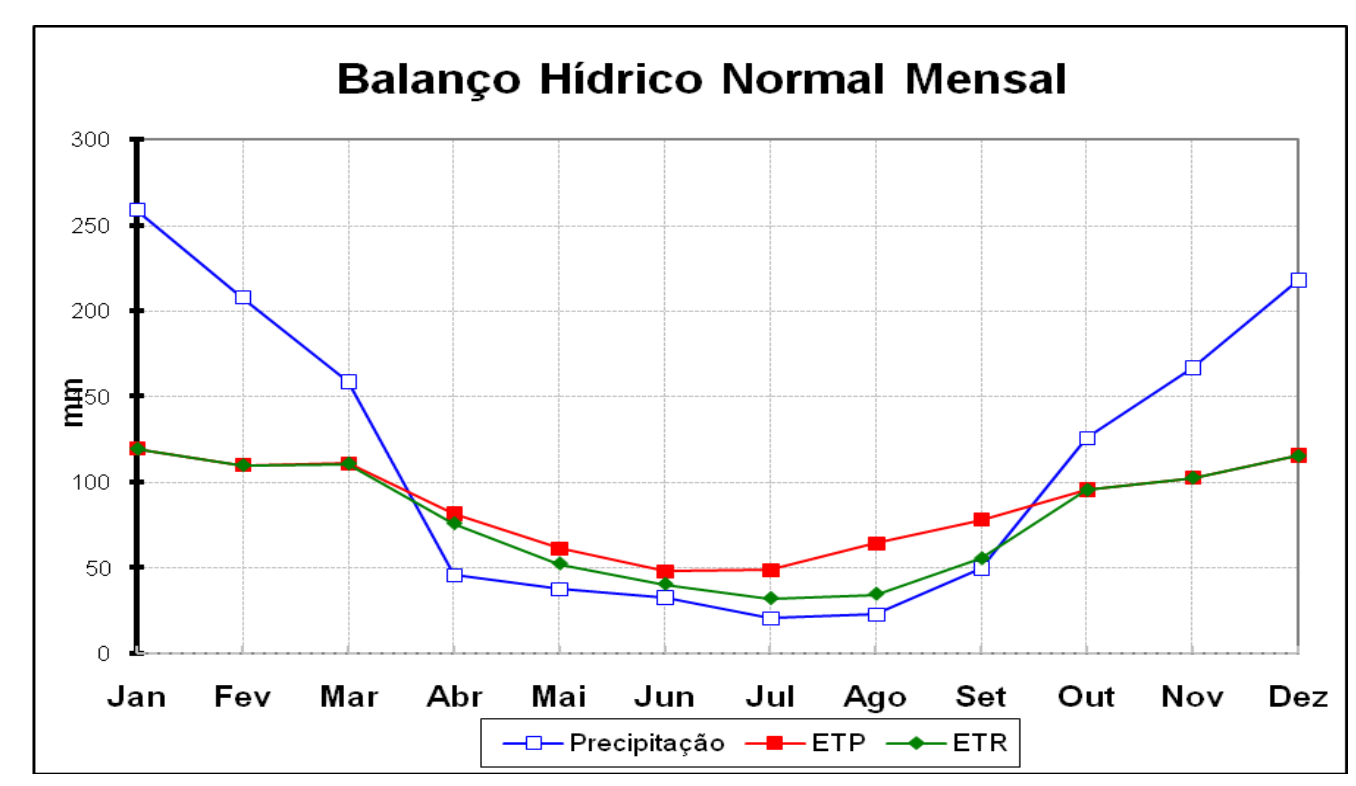

Fonte: Sentelhas et al. (1999)

Figura 2: Balanço hídrico normal mensal por Thornthwaite \& Mather para o posto do DAEE em Descalvado.. Período de dados: 1941 a 1970. Localização do posto: 21,91 S e 47,63 W. Altitude do posto: $648 \mathrm{~m}$. 


\subsubsection{Geologia}

A região de Descalvado está situada na sub-bacia do Alto Paraná, que compreende os estados de São Paulo, Goiás e Minas Gerais, delimitada ao sul pelo alinhamento tectônico do Paranapanema. A bacia do Paraná é considerada como intratectônica isolada.

A área ocupada pela mineração Descalvado é constituída por rochas sedimentares. Estratigraficamente PA, Brasil (2008) descreve uma litologia formada por aluviões, formações superficiais, formação Botucatu e formação Pirambóia. A seguir as litologias da área são descritas sucintamente:

a) Os aluviões são depósitos de calha de rio, areno-argilosos, situados em planícies de inundação (várzeas) do Ribeirão Bonito e do Córrego da Bomba. São originados por retrabalhamento de materiais pré-existentes na região, a saber: arenitos Botucatu e Pirambóia, rochas básicas e formações superficiais, efetuados pela drenagem atual durante o processo de encaixamento.

b) As formações superficiais compõem o material de cobertura de quase toda a área da mineração, sendo constituído por sedimentos arenosos de granulação fina a média, imersos em matriz argilosa. Os grãos de quartzo constituintes revelam-se de retrabalhamento da formação Botucatu, subjascente.

c) A formação Botucatu é constituída por arenitos inconsolidados de granulação fina a média com grãos foscos e arredondados. A espessura máxima observada desta camada na área da jazida é da ordem de $20 \mathrm{~m}$.

d) A formação Pirambóia, constituída por arenitos inconsolidados de granulação fina a média, apresenta grãos angulosos e brilhante, com matriz argilosa. Como o Pirambóia é um sedimento nitidamente depositado em ambiente aquoso, não se pode enquadrá-lo como base do Botucatu, que por definição é um sedimento eólico.

No local da mineração o conjunto das formações Botucatu/Pirambóia possui uma espessura de ordem de 120 a $150 \mathrm{~m}$. 


\subsubsection{Geomorfologia}

A região de Descalvado pertence à unidade morfoestrutural designada como "Cuestas Basálticas". É caracterizada pelo esculpimento em camadas areníticas e de rochas básicas, pelos processos de denudação ocorridos desde o Cretáceo, com suas cimeiras alcançando altitudes de 800 a 1000 metros.

$\mathrm{Na}$ diversidade de paisagens topográficas da região se distinguem três formas de relevo:

a) relevos com encostas suavizadas: apresentam declividades superiores a $15 \%$, com predominância de morros amplos, possuem vales abertos com planícies inferiores restritas e estão sujeitos à ocorrência de boçorocas.

b) relevos de transição com encostas não escarpadas: predominam declividades médias entre 15 a 30\%, apresentam vales fechados e drenagem de média intensidade;

c) relevos residuais: são suportados por rochas sedimentares e constituídos por mesas sedimentares com morros tabulares de bordas escarpadas e topos achatados.

Na região são observadas algumas particularidades geográficas como o Salto do Pântano com quase $80 \mathrm{~m}$ de altura à sudeste da mineração, o Morro da Janelinha à noroeste e ao sul o Morro de Descalvado, na Serra homônima, com altitude de $1000 \mathrm{~m}$.

$\mathrm{Na}$ área da mineração, as características morfológicas locais pertencem à forma de relevo mencionada como morros com encostas suavizadas. Também há características que se enquadram no relevo de transição com encostas não escarpadas. Visualmente, o relevo é suave-ondulado, com fundo do vale chato e constituído por planície aluvionar, sujeita a inundações periódicas do ribeirão Bonito, com drenagem de baixa densidade. A planta topográfica da mineração indica a cota máxima de 700 m e a mínima de $665 \mathrm{~m}$. 


\subsubsection{Recursos Hidricos}

Os dois corpos de água na área do empreendimento são o ribeirão Bonito com vazão média estimada de $1,0 \mathrm{~m}^{3} / \mathrm{s}$ e o córrego da Bomba com vazão média estimada de $0,3 \mathrm{~m}^{3} / \mathrm{s}$.

Quanto à sua posição hidrográfica, a mineração está situada à margem esquerda do ribeirão Bonito, distando aproximadamente $2 \mathrm{~km}$ da sua nascente na Serra de Descalvado, e a $22 \mathrm{~km}$ na sua afluência junto ao rio Mogi-Guaçu. À montante da área da mineração, o ribeirão Bonito não recebe nenhum afluente, tendo contribuição apenas de algumas pequenas drenagens. No próprio terreno recebe como afluente o córrego da Bomba. Todos os rios da região fazem parte da bacia hidrográfica do rio Mogi-Guaçu, destacando-se o rio Quilombo, o rio Pântano e o rio Bonito como os principais afluentes.

\subsubsection{Solos}

Em Descalvado o tipo de solo que prevalece é o Latossolo-Vermelho, comumente denominado terra roxa, cobrindo $60 \%$ da área do município. São solos bem profundos e férteis, muito adequados à agricultura. Outros tipos de solo presentes são o Latossolo Vermelho-Amarelo e o Neossolo quartzarênico. Em menor proporção se encontram os solos Hidromorfos e os Neossolos Litólicos.

$\mathrm{Na}$ área da mineração verifica-se o predomínio de solos classificados pedologicamente como Latossolo Vermelho-Amarelo com textura areno-argilosa (LVa) e solos Hidromorfos nas planícies aluvionares $(A L)$.

Os Latossolos Vermelho-Amarelo de textura areno-argilosa são formados pela decomposição de arenitos e ocorrem naturalmente em relevo suave-ondulado. $\mathrm{Na}$ área da mineração eles são derivados das formações Botucatu e Piramboia e se encontram nas cotas mais altas (600 a 700 m. O pH do solo é ácido, com teor de carbono relativamente baixo, tanto na camada superficial, como na sub-superficial. São muito pobres em nutrientes e apresentam baixa atividade coloidal. A variação de porcentagem da areia e argila na textura é conseqüência da gênese destes materiais. Os arenitos provenientes da formação Botucatu são de origem eólica tendo, portanto, menos argila (na ordem de $5 \%$ ) que os arenitos subjacentes da 
formação Pirambóia, de origem fluvial. Quanto às suas restrições edáficas, são solos de baixa fertilidade e sofrem redução na retenção de água pela acentuada porcentagem de areia. As vegetações originais eram de Cerrado ou de Cerradão.

Os solos hidromorfos, também denominados aluvionares, ocorrem nas várzeas. A topografia plana favoreceu o depósito de materiais nas planícies de inundação do ribeirão Bonito, originando solos característicos. Devido à alta complexidade e variedade dos materiais depositados, o solo aflorante nestas áreas não é uniforme, variando desde arenosos puros a argilosos puros, com várias gradações de mistura. As restrições quanto ao uso agrícola destes solos estão em função do nível estático elevado. Várzeas devidamente drenadas têm se revelado com alta fertilidade na região.

\subsubsection{Vegetação}

As categorias de cobertura vegetal no entorno imediato da Mineração Descalvado compreendem vegetação natural, matas ciliares, revegetações com nativas, plantios de eucalipto e pastagens.

A cobertura vegetal natural remanescente está classificada como formação vegetal Cerrado-Cerradão (PA BRASIL, 2008). Ab'Saber (2009) refere que o Cerrado apresenta três padrões de ecossistemas predominantes: os Cerrados propriamente ditos, os Cerradões e os Campestres. Segundo esse autor, os Cerrados são formados por vegetação com árvores baixas e troncos retorcidos, de imediato reconhecimento: plantas de tronco lenhoso com galhos retortos e bizarros, que perdem as folhas durante a estação mais seca do ano. Nestas áreas, a luminosidade e o calor atingem o chão, por entre as arboretas e pequenas árvores. Os Cerradões constituem uma vegetação arbórea que se destaca na paisagem geral dos Cerrados, diferenciando-se fisionomicamente destes pela altura e maior biomassa vegetal. Entretanto, os Cerradões são compostos em grande parte das espécies mais desenvolvidas existentes nos Cerrados, incluindo porém, apertados sub-bosques e alguma vegetação herbácea. Para o autor a grande diferença reside na flora das florestas-galeria de complexa composição biótica que se estendem em fundo de vales. As matas ciliares ou ribeirinhas também fazem a diferença ecossistêmica no domínio do Cerrado. Os Campestres aparecem em altiplanos de 
solos arenosos com vegetais gramíneos pontilhados de palmeiras anâs entremeadas com espaçadas plantas dos cerrados antes referidos. Carvalho (2008) menciona três estratos de vegetação no Cerradão: arbóreo com 8 a 10 m de altura; arbustivo, mais denso com cerca de $3 \mathrm{~m}$ de altura; e herbáceo mais reduzido.

A partir do ponto central da lavra da mineração, num raio de aproximadamente 2 quilômetros ao norte, parte da mata está originalmente preservada e, parte em fase avançada de regeneração. Ao sul e ao oeste, as áreas de Cerradão outrora atingidas por fogo e outras intervenções, como a coleta de lenha, estão em processo de regeneração. Ao leste e ao nordeste da área observam-se reflorestamentos com Eucaliptus grandis (eucalipto) nas áreas pertencentes à Mineração Jundu. Na Foto 5 visualiza-se esta descrição.

No levantamento feito pela PA Brasil (2008) considera-se a vegetação florestal remanescente da Mineração Descalvado como fragmento de Cerradão, mezclado à Floresta Estacional SemidecíduaL (FES).

As matas ciliares do córrego da Bomba e do ribeirão Bonito constituem áreas de proteção permanente e atualmente se encontram num estágio médio de regeneração, com grau de antropização relativamente elevado, conforme a presença de capim braquiária e o dossel rebaixado e irregular. Comportam espécies típicas de Cerrado, mas também detêm espécies de Mata Atlântica (PA BRASIL, 2008). Além das áreas já referidas, as revegetações existentes no terreno da mineração devem ser incluídas como parte do levantamento da vegetação. Foram executadas a partir de 1995 em áreas anteriormente mineradas, prevendo a revegetação do local com espécies típicas da região (Bioma Cerrado) para criar condições favoráveis à recomposição ecológica do local. As revegetações foram implantadas em locais de taludes, pátio de sucatas, matas ciliares, antiga bacia de rejeitos e antigas frentes de lavra, sendo que o presente estudo é desenvolvido sobre as revegetações realizadas na antiga bacia de disposição de rejeitos.

Em um raio mais amplo, a vegetação compreende áreas com cobertura natural remanescente com formações vegetais de Cerrado e Cerradão. As observações no município de Descalvado mostram que as formações vegetais naturais reduziram-se muito, sendo substituídas por atividades agro-pastoris e avícolas, ocorrendo alterações fisionômicas marcantes pela presença de reflorestamentos com eucalipto e, mais recentemente, com cana de açúcar. Muitas áreas de mata, abandonadas após o uso, estão em lenta regeneração natural, 
representado por espécies de porte arbóreo (2 a $6 \mathrm{~m}$ ), arbustivo e rasteiro (gramíneas), porém ainda caracteristicamente ralo.

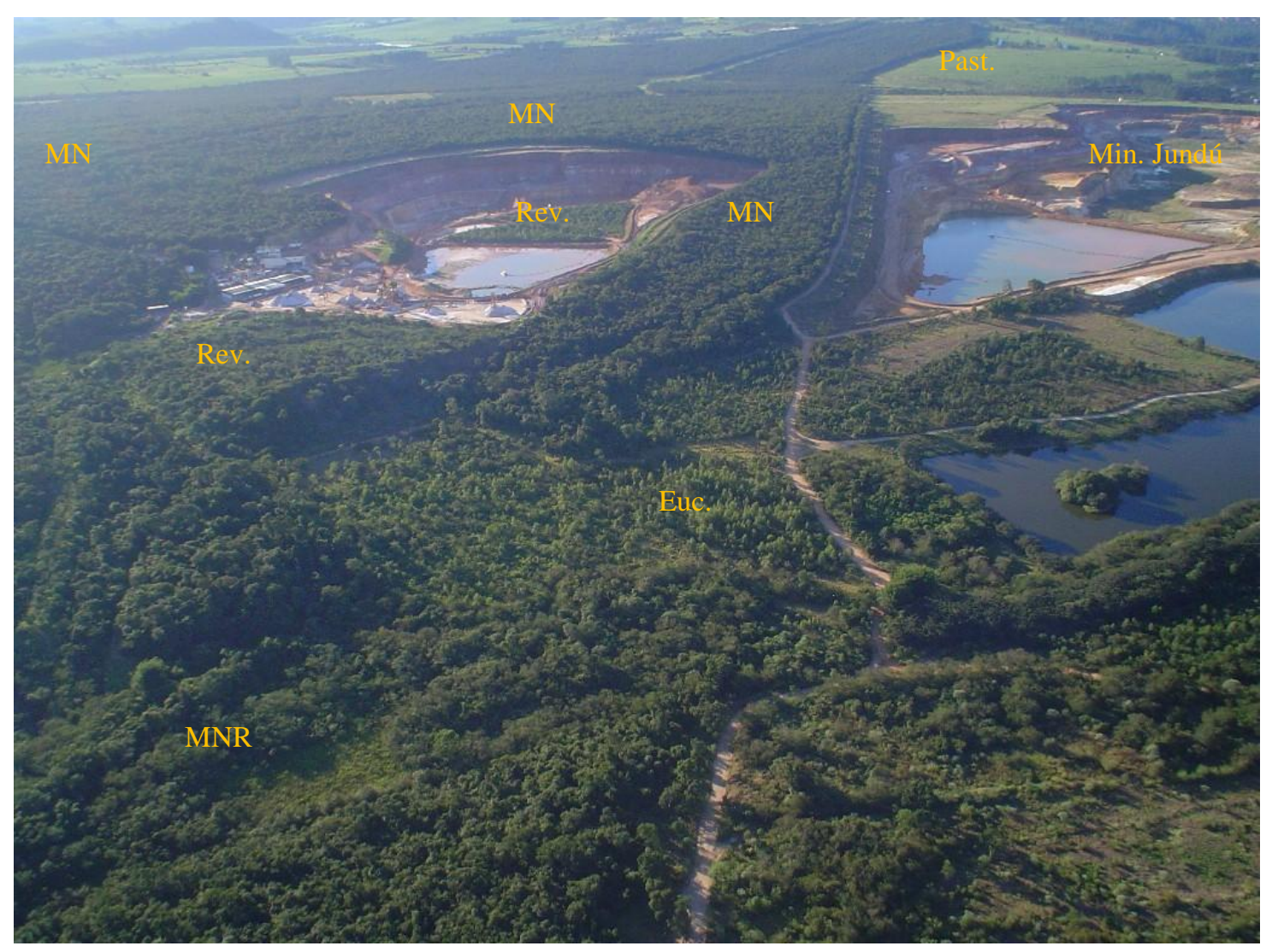

Fonte: Mineração Descalvado

Foto 5: Tipos de vegetação na circunvizinhança da Mineração Descalvado (2007). MN: mata nativa, MNR: mata nativa em regeneração, Rev.: revegetações, Euc.: plantio de eucaliptos e Past.: pastagens.

\subsubsection{O processo produtivo da Mineração Descalvado}

Conforme informações contidas em Almeida (2004) e complementadas com dados fornecidos pela Mineração Descalvado, apresenta-se, um quadro das características operacionais da mina.

A jazida se caracteriza pela presença de arenitos quartzosos de alta pureza, intercalados com areias de espessuras e composições granulométricas variadas, 
formando cinco camadas superpostas com características distintas de cor, granulometria e conteúdo de minerais escuros, sendo do topo para a base: uma formação superficial denominada Santa Rita, uma camada de transição sem dominação específica, Botucatu, outra camada de transição, e Pirambóia. A camada Santa Rita tem, na mina, espessura de 8 a $14 \mathrm{~m}$, sendo formada por areias escuras e cascalho; apresenta alto teor de ferro e seu material é utilizado para recuperação de áreas e para o uso na construção civil. Na primeira camada de transição, com espessura de alguns centímetros até $5 \mathrm{~m}$, predomina areia de granulação média a fina de cores rosadas, mas surge em alguns locais apenas como cascalho que recobre a camada subseqüente. A camada Botucatu é formada por arenitos de granulação fina a média de cor avermelhada na parte superior e amarelada na parte inferior, e com espessura variando de 14 a $27 \mathrm{~m}$, destina-se para produção de areia vidreira, de fundição e para construção civil como subproduto. Ocorre então uma segunda camada de transição, atualmente no piso da cava, na cota $650 \mathrm{~m}$, com predominância de materiais do tipo cascalho com poucos centímetros até $6 \mathrm{~m}$ de espessura. Finalmente há a formação Pirambóia que hoje está abaixo do nível do piso da cava devido ao seu mergulho no sentido $N$, mas que no passado também era destinada à produção das areias- padrão dos produtos da mineração.

A lavra se desenvolve a céu aberto com formação de bancadas e caracterizase pela remoção seletiva do minério, utilizando escavação mecânica a seco por ação direta de retroescavadeiras. O carregamento é direto em caminhões basculantes que transportam o minério até uma caixa alimentadora das unidades de lavagem da areia. As mesmas operações são aplicadas na camada Santa Rita, cujo material é tratado como estéril e destinado aos aterros das obras de recuperação ou comercializado para o uso na construção civil. Tratores e pás-carregadeiras são utilizados para remoção e empilhamento de solo reaproveitável; espalhamento do estéril nos locais das obras de recuperação; espalhamento do solo orgânico estocado sobre áreas recuperadas para o posterior plantio de espécies arbóreas e operações auxiliares de carregamento do minério.

Os taludes formados (três ao todo) têm aproximadamente 10 a $15 \mathrm{~m}$ de altura, com bermas de pelo menos $5 \mathrm{~m}$ de largura; o fundo da cava está estabelecido na cota limite 650. Como se visualiza na Foto 6, na área de lavra existe água aflorante e sua remoção é feita por sistema de bombeamento que recalca a água para a bacia de contenção das frações argilosas geradas como rejeitos 
durante o beneficiamento. Neste local ocorre a recuperação da água utilizada no processo de beneficiamento, de onde o excedente após tratamento adequado, flui para o côrrego da Bomba.

A lavra está dimensionada para 65.000 t/mês de areia sendo conduzida por empresa terceirizada, em regime de trabalho com três turnos diários de oito horas cada. Cálculos estimativos indicam uma vida útil da jazida de aproximadamente oito anos, dependendo da escala futura de produção da mina. Há um projeto de expansão em fase de licenciamento ambiental.

Após a lavra, o minério é transportado para os locais de alimentação dos lavadores de areia e misturado com água para formação de polpa. Inicia-se então o beneficiamento da areia por via úmida. Após o beneficiamento, os produtos nas pilhas são carregados por pá-carregadeira sobre pneus e transportados por caminhões até os locais de alimentação dos secadores. O rejeito gerado é depositado em bacias localizadas dentro da própria cava, aproveitando os espaços antes minerados.

O ciclo básico de produção requer operações auxiliares, destacando-se: manutenção geral dos equipamentos de lavra, das operações de lavagem e secagem e dos painéis de controle; manutenção geral dos acessos internos e das condições de estabilidade dos taludes; sistemas de bombeamento de água; tratamento e monitoramento da qualidade da água; procedimentos de recuperação com obras de construção e manutenção da bacia de rejeito e revegetação de áreas; entre outros.

A Mineração Descalvado possui a certificação ISO 9001 de qualidade e foi recentemente certificada na ISO 14001 do Sistema de Gestão Ambiental. 


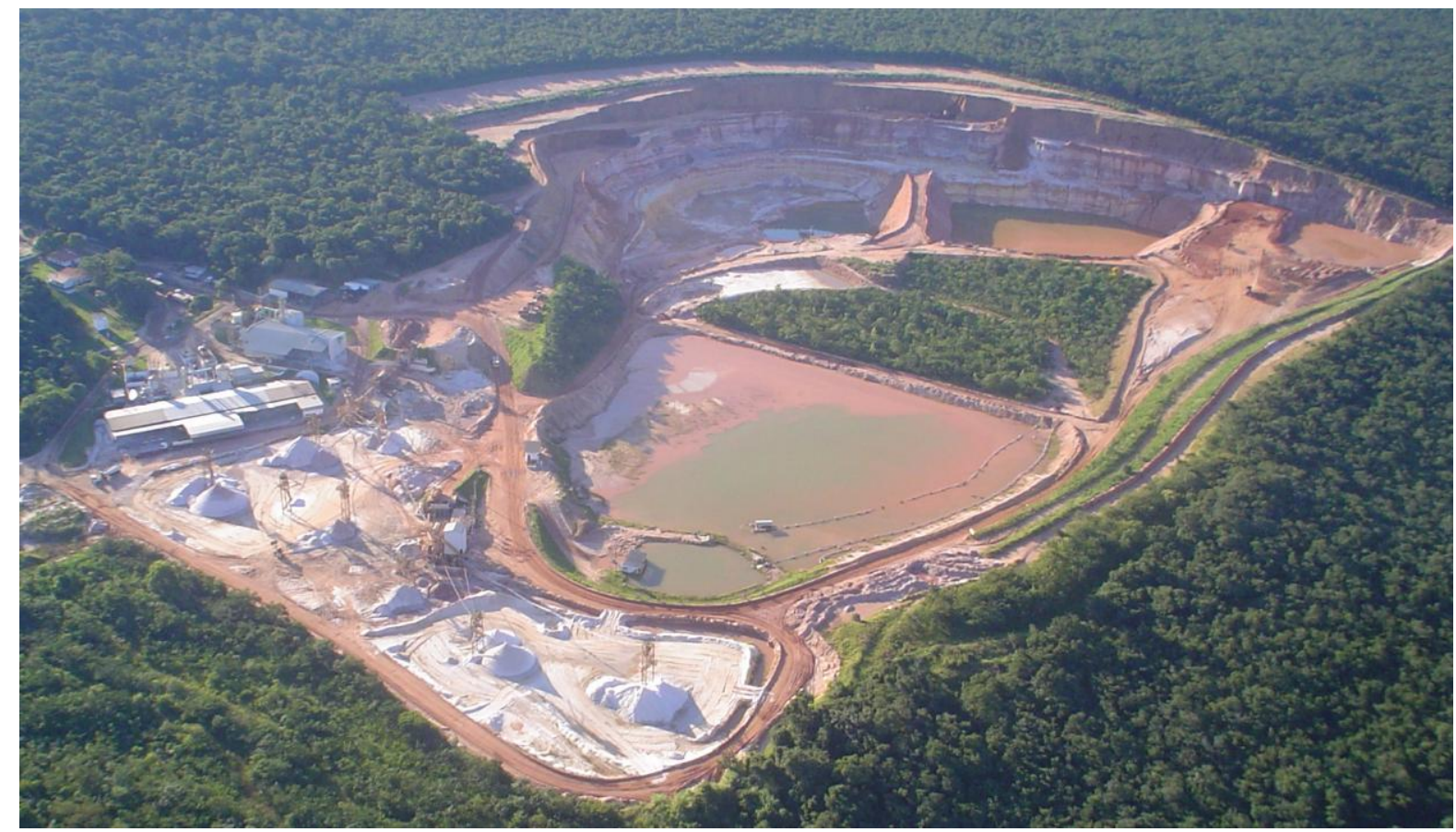

Fonte: Mineração Descalvado

Foto 6: Vista geral da cava e da área operacional de beneficiamento da mineração Descalvado (2007).

\subsubsection{Atividades de recuperação das áreas degradadas na Mineração Descalvado}

Dentro do PRAD, implantado pela empresa entre 1995 e 1996 (Descalvado Mineração, 1997), foram estabelecidos procedimentos específicos para a estabilização e recuperação dos taludes gerados pela movimentação de terra e para a revegetação da antiga cava utilizada posteriormente como bacia de disposição dos rejeitos do processo de beneficiamento do minério. Foram também definidas as medidas mitigadoras envolvendo a segurança viária e o impacto visual, além do monitoramento periódico de parâmetros de ar, água e solo.

Para a recuperação dos taludes se propiciou uma rápida cobertura vegetal com a espécie gramínea capim braquiaria (Brachiaria decumbens) visando melhorar a estabilidade e controlar a erosão.

$\mathrm{Na}$ antiga cava, após a exploração do minério houve a suavização dos taludes e acondicionamento para servir como bacia de disposição de rejeitos. $\mathrm{O}$ 
rejeito depositado se caracteriza por apresentar granulometria silte-argilosa, ser pouco poroso e reter umidade excessiva. A seqüência dos trabalhos de recuperação se iniciou com a secagem e 0 adensamento dos rejeitos. Posteriormente houve a colocação de uma camada de material estéril (arenoso) e a aplicação superficial de uma camada de solo orgânico proveniente da ampliação da cava. A adição do estéril e do solo superficial é uma medida para diminuir o efeito negativo do material fino do rejeito sobre o crescimento das plantas. ${ }^{3}$

Com relação aos trabalhos de revegetação, de acordo com o PRAD (Descalvado Mineração, 1997), na superfície preenchida da bacia foi colocado 1 t/ha de calcário em toda sua extensão. Posteriormente, realizou-se semeadura a lanço de capim braquiária para facilitar a consolidação do substrato e melhorar as condições do local para o posterior plantio das mudas de espécies arbóreas.

A preparação para o plantio de mudas consistiu na abertura de covas de 0,40 x 0,40 x 0,50 m preenchidas com a mistura de $200 \mathrm{~g}$ de calcário, 10 a $15 \mathrm{I}$ de esterco de curral, $300 \mathrm{~g}$ de fertilizante fosfatado e solo superficial proveniente de locais a serem minerados. As mudas plantadas receberam adubação em quatro parcelas durante os períodos de chuvas. Também foram irrigadas até o seu pleno desenvolvimento, principalmente nos períodos secos ou veranicos, para que não tivessem seu crescimento prejudicado. Nos primeiros três meses, após o plantio ocorreu a reposição de todas as falhas ou mudas que não se desenvolveram (replantio). Os cuidados pós-plantio consistiram na realização de coroamento ou limpeza das covas ao redor das mudas, até que elas atingissem porte suficiente para superar a competição com as plantas invasoras que as cercam, principalmente o capim brachiaria. Também se realizaram roçamentos de linhas, podas de limpeza, eliminando ramos quebrados, secos e/ou doentes e combate de pragas e doenças quando necessário.

Análises anuais de solo realizados no substrato foram utilizadas para a dosificação da calagem e da adubação nas covas. Quando as árvores atingiram de 2 a $3 \mathrm{~m}$ de altura já não foram mais adubadas nem irrigadas, fato que aconteceu aproximadamente dois anos após o plantio de mudas. Todas as atividades de revegetação e os cuidados com manutenção foram efetuados por uma empresa terceirizada, assistidos por um engenheiro agrônomo que, a partir de 2001,

\footnotetext{
${ }^{3}$ Conforme informações fornecidas pela gerência da mina em 08/08.
} 
apresentou relatórios anuais à Mineração, com informações e recomendações pertinentes aos trabalhos do período.

\subsection{Aplicação metodológica}

\subsubsection{O local da pesquisa}

O local de interesse para a pesquisa é a antiga bacia de rejeito com aproximadamente 5 ha (Foto 7) onde, a partir de 1995 e após a execução dos procedimentos descritos no item 3.1.4, foram sendo plantadas espécies arbóreas como parte do processo de recuperação. Primeiramente, a área da bacia foi separada em três partes para facilitar a disposição do rejeito (material argiloso), de maneira que as diferentes áreas foram sendo cobertas com o material arenoso (estéril) e revegetadas à medida que iam sendo preenchidas.

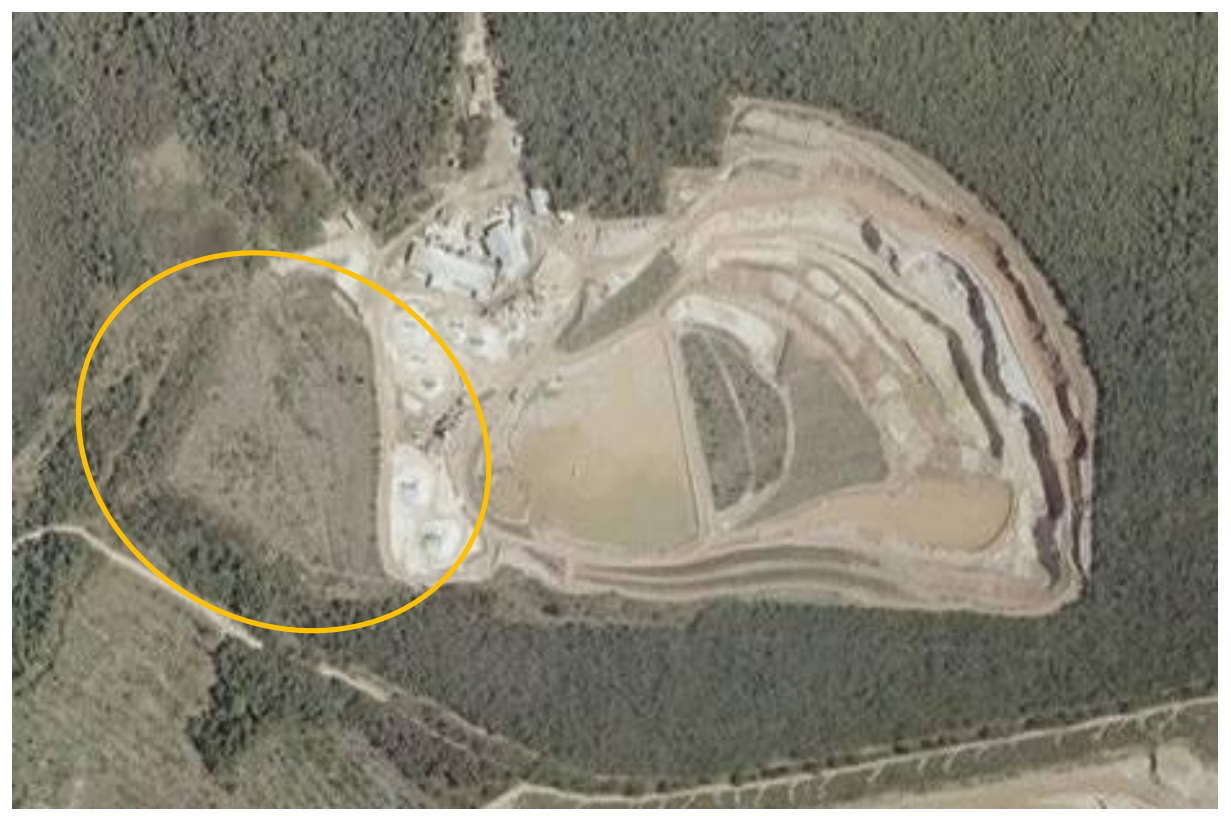

Fonte: Mineração Descalvado

Foto 7: Antiga bacia de disposição de rejeitos, já revegetada (ampliação de foto aérea, 2006). 
O levantamento das informações fornecidas pela atual gerência da empresa e as observações iniciais permitiram identificar que a primeira área a ser revegetada na mineração, em 1995, foi a encosta do lado leste da bacia (área A1). Em 1998, foi revegetada a parte leste da área da bacia (área A2); no ano 2001, a porção oeste da mesma área (área A3); em 2003, foi revegetada a área remanescente (área A4). Estas quatro áreas com diferentes idades de revegetação configuram uma cronosseqüência, que será para a observação no estudo da evolução temporal do substrato. O remanescente de mata nativa do entorno (A5) servirá como área de referência, representando, de forma semelhante, o ambiente existente antes da atividade de lavra. Uma nova bacia de rejeito (A6), com preparo de substrato semelhante ao da bacia mas que ainda não foi revegetada, foi escolhida para constituir o ano zero da cronosseqüência.

A Figura 3 contém o mapa de situação da mineração onde se distinguem as áreas revegetadas da bacia (A1, A2, A3 e A4) e se situam as demais áreas de estudo (A5 e A6). Antes de 2001 não existem registros escritos sobre as datas exatas dos plantios realizados, somente informações orais. Portanto, as datas de plantio devem ser consideradas de forma aproximada.

Os documentos de consulta disponibilizados pela empresa foram o PRAD (1997) e alguns dos relatórios referidos no item 3.1.3. Não foi possível identificar se há outros documentos relativos à recuperação de áreas degradadas, tais como procedimentos internos ou relatórios específicos de monitoramento. Adicionalmente foram consultados o EIA-RIMA (1990) e o EIA-RIMA (2008) disponibilizados pela Secretaria de Meio Ambiente do Estado de São Paulo. 


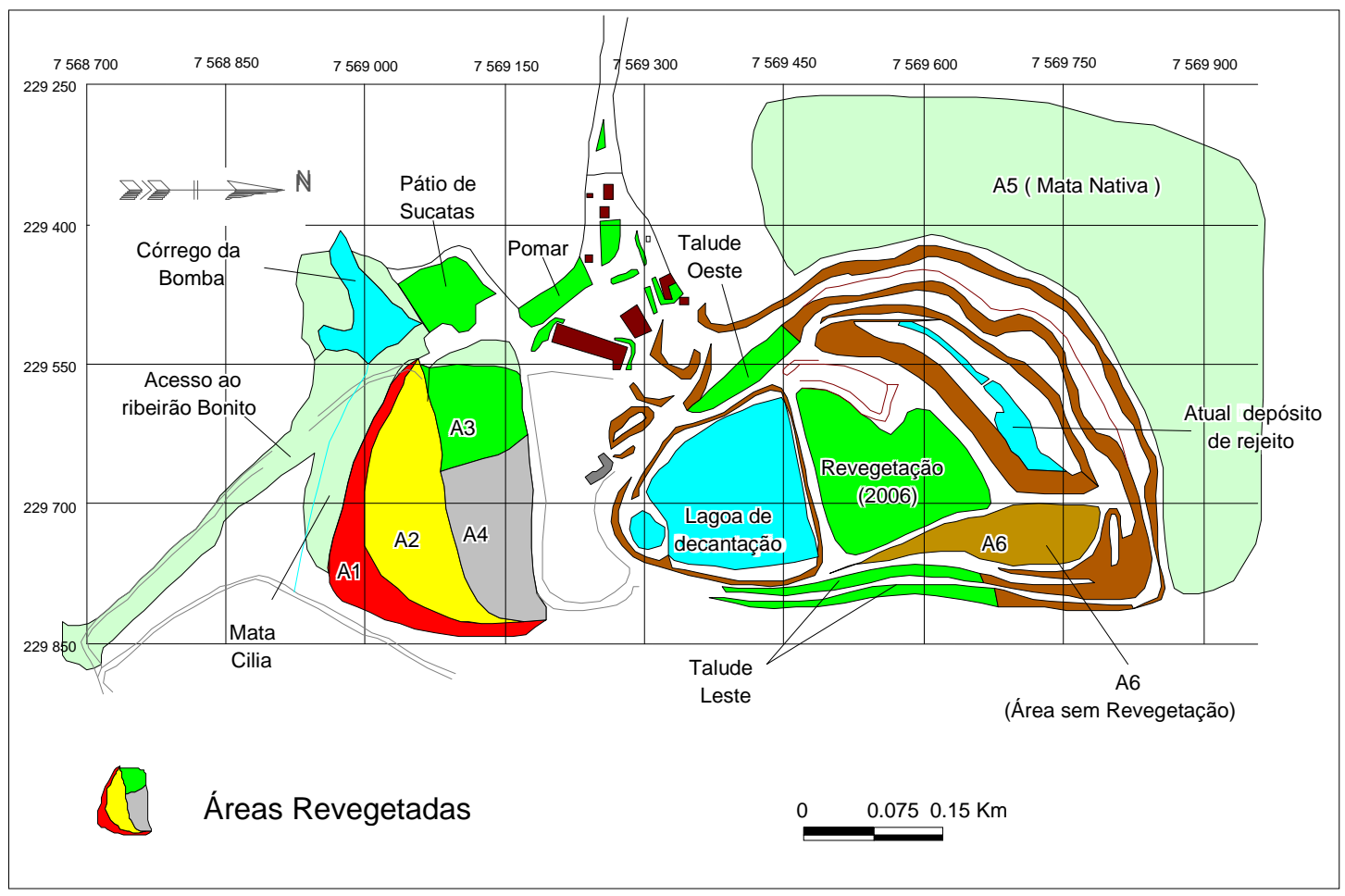

Fonte: Adaptado de Mineração Descalvado

Figura 3: Mapa da Mineração Descalvado destacando a antiga bacia de disposição de rejeitos e as áreas de estudo A1, A2, A3, A4, A5 e A6.

\subsubsection{Trabalhos de campo}

Nesta fase da investigação realizou-se preliminarmente a observação geral das condições do substrato acondicionado na bacia e as atividades de amostragem para a posterior caracterização física e química em cada uma das áreas de estudo.

\subsubsection{Observações preliminares}

As primeiras visitas à mineração foram realizadas para se adquirir familiaridade com o histórico do processo de recuperação das áreas degradadas e com as ações adotadas nas situações de degradação em geral (item 3.1.4). No planejamento dos trabalhos de amostragem na bacia, houve um reconhecimento 
prévio das condições do substrato, pois se desconhecia a profundidade do estéril adicionado, a profundidade em que se encontrava o material de rejeito mais fino e o comportamento do crescimento das raízes da vegetação implantada. Com este propósito foram abertas cinco trincheiras de reconhecimento, determinando ao menos uma trincheira por área revegetada e situadas em local representativo. Esta observação inicial das áreas da bacia permitiu estabelecer uma primeira avaliação e o reconhecimento preliminar do estado do substrato e das características do meio.

\subsubsection{Amostragem do substrato}

A amostragem foi realizada nas áreas revegetadas da bacia (A1, A2, A3, A4 respectivamente), assim como na área de mata (A5) e na área sem revegetação (A6), totalizando seis áreas de investigação. Para tal propósito, foram abertas três trincheiras por área, onde se realizou a extração de amostras a cada $20 \mathrm{~cm}$, até os $80 \mathrm{~cm}$ (cinco amostras por trincheira). Com a abertura das três trincheiras em cada área de observação, e amostragem a cada $20 \mathrm{~cm}$ de profundidade, foi programada a retirada de 15 amostras por área, totalizando 90 amostras nas seis áreas selecionadas.

Os pontos determinados para a abertura das trincheiras foram estabelecidos evitando possíveis efeitos de borda e localizados em campo mediante a utilização de GPS. A Tabela 4 apresenta o posicionamento UTM de cada um desses pontos. Complementando estas informações, a Figura 4 exibe a distribuição espacial das trincheiras de amostragem em cada área revegetada. 
Tabela 4: Características das áreas de estudo e localização (UTM) de cada trincheira de amostragem.

\begin{tabular}{|c|c|c|c|c|c|}
\hline \multirow[t]{2}{*}{ Área } & \multirow[t]{2}{*}{$\begin{array}{c}\text { Ano de } \\
\text { revegetação }\end{array}$} & \multirow[t]{2}{*}{$\begin{array}{c}\text { Idade de } \\
\text { revegetação }\end{array}$} & \multicolumn{3}{|c|}{$\begin{array}{l}\text { Localização das } \\
\text { trincheiras em } \\
\text { Coord. UTM }\end{array}$} \\
\hline & & & R1 & $\mathbf{R 2}$ & R3 \\
\hline & & & 229742 & 229628 & 229760 \\
\hline \multirow[t]{2}{*}{$\mathrm{A} 1$} & 1995 & 14 anos & 7569014 & 7569019 & 7569067 \\
\hline & & & 229706 & 229681 & 229618 \\
\hline \multirow[t]{2}{*}{ A2 } & 1998 & 11 anos & 7569039 & 7569052 & 7569069 \\
\hline & & & 229582 & 229555 & 229589 \\
\hline \multirow[t]{2}{*}{ A3 } & 2001 & 8 anos & 7569123 & 7569103 & 7569102 \\
\hline & & & 229667 & 229712 & 229754 \\
\hline \multirow[t]{2}{*}{ A4 } & 2003 & 6 anos & 7569122 & 7569168 & 9569154 \\
\hline & & & 229259 & 229397 & 229197 \\
\hline \multirow[t]{2}{*}{ A5 } & - & - & 7569815 & 7569910 & 7569604 \\
\hline & Sem & & 229700 & 229658 & 7569725 \\
\hline A6 & revegetação & . & 7569752 & 769780 & 229688 \\
\hline
\end{tabular}




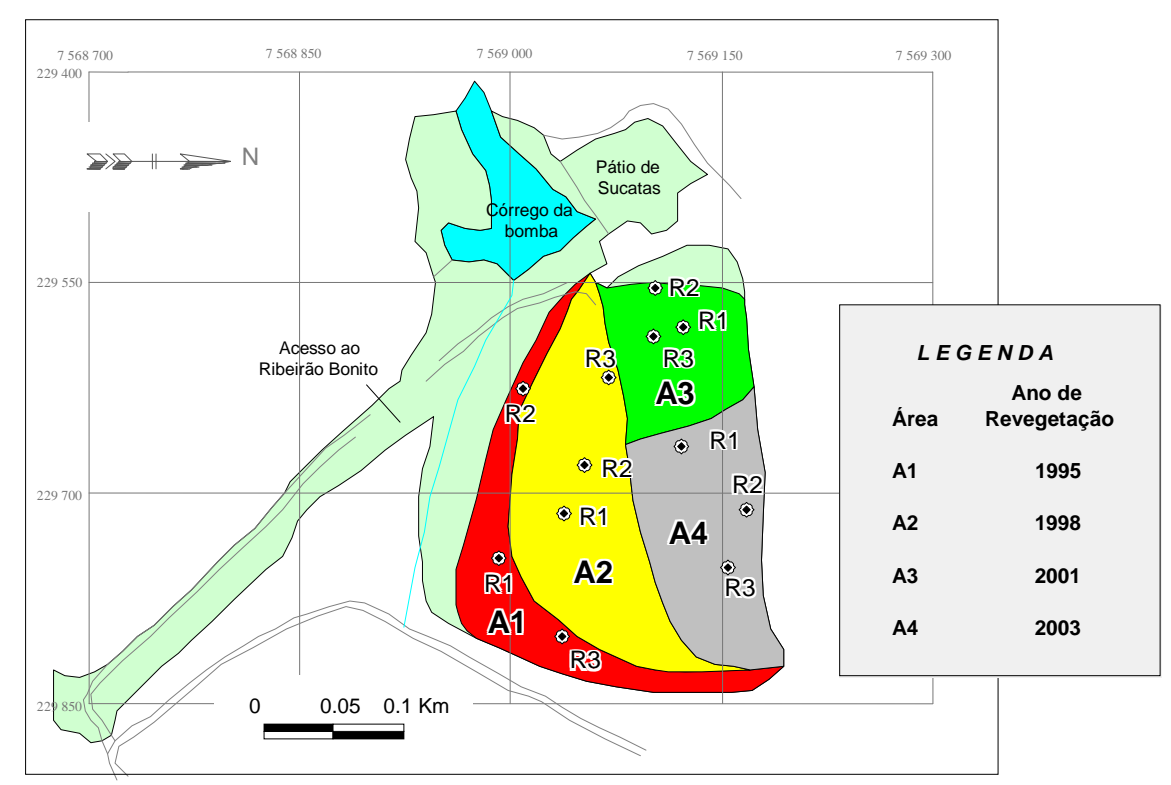

Fonte: Adaptado de Mineração Descalvado.

Figura 4: Áreas revegetadas na bacia com a localização dos pontos de abertura das trincheiras para amostragem.

$\mathrm{Na}$ abertura das trincheiras procedeu-se à escolha do lugar sempre próximo a uma árvore para ampliar a oportunidade de observação do crescimento das raízes. Um cuidado adicional nos estágios iniciais foi o de não pisotear um dos lados da trincheira e também levar toda a terra cavada sempre para o lado oposto, de maneira a facilitar a obtenção de amostras e a captação dos registros fotográficos do lado intocado. A profundidade das trincheiras cavadas variou de $1 \mathrm{~m}$ a $1,10 \mathrm{~m}$ com aproximadamente 1,5 $\mathrm{m}$ de comprimento e $1 \mathrm{~m}$ de largura.

A abertura das trincheiras consistiu numa tarefa árdua, devido à compactação do material e à baixa umidade, pois foi realizada em tempo de seca. Para facilitar a abertura, em alguns casos de extrema dureza, foi necessário jogar água no local a ser escavado. Uma vez aberta a trincheira, procedeu-se à amostragem, a cada 20 $\mathrm{cm}$, a partir da superfície. Em cada profundidade foram retirados três tipos de amostras: 
- uma amostra de solo ou substrato indeformado, para análise de densidade de solo, coletada com trado amostrador específico e numerada segundo a área e a profundidade;

- em torno de 0,5 kg de solo ou substrato destinado à análise granulométrica, sendo acondicionado em saco plástico e numerada segundo a área e a profundidade e;

- em torno de 0,5 kg de solo ou substrato, destinado às análises químicas, sendo acondicionado em saco plástico e numerado segundo a área e a profundidade.

A rotina de amostragem consistiu na retirada da amostra indeformada na superfície, tomando-se o cuidado de tirar galhos, pedras e restos de plantas; na seqüência coletaram-se duas amostras deformadas de solo, com aproximadamente 0,5 kg cada uma para os ensaios de análise química e granulométrica, respectivamente; retirou-se a porção demarcada de solo até os $20 \mathrm{~cm}$ de profundidade e novamente, uma amostra indeformada correspondente a essa profundidade e assim sucessivamente, a cada $20 \mathrm{~cm}$, até se atingir a profundidade de $80 \mathrm{~cm}$. Em cada trincheira, obteve-se um total de 15 amostras, sendo 5 amostras indeformadas, 5 sacos de $0,5 \mathrm{~kg}$ para granulometria e 5 sacos de 0,5 kg para análise química a 0,20, 40, 60 e $80 \mathrm{~cm}$ de profundidade, respectivamente.

$\mathrm{Na}$ amostragem indeformada, utilizou-se um trado amostrador fabricado pela empresa Sondaterra, para coleta de amostras em cilindros de aço inoxidável, com 50 $\mathrm{mm}$ de diâmetro, $51 \mathrm{~mm}$ de altura e volume de $100 \mathrm{~cm}^{3}$. O kit é composto de coletor com capacidade para um cilindro com cabo de $15 \mathrm{~cm}$, hastes prolongadoras de 40 $\mathrm{cm}$, batedor com $10 \mathrm{~cm}$ de comprimento, cabo extrator, marreta de ferro, cilindros de inox, chaves com boca $16 \mathrm{~mm}$ e espátula fina. Obteve-se cinco cilindros amostrais de cada trincheira, totalizando 90 cilindros amostrais. Devido ao grau de compactação dos substratos acondicionados não foi possível usar as hastes prolongadoras deste equipamento o que permitiria realizar amostragens sem necessidade de abertura de trincheiras.

Em locais com material solto, bastaram de 10 a 15 impulsos percursivos para se obter a amostra (Foto 8). Quando o substrato se apresentou seco ou muito compactado foram necessários até 150 ou mais impulsos. Houve casos em que o trado não penetrou nem mesmo com esta quantidade de percussões e foi preciso umedecer o solo pelas bordas do amostrador, para facilitar o seu deslizamento no substrato. Sobre esse comportamento, Klein (2007) assinala que, no momento da 
coleta deve-se tomar cuidado especial com a umidade, pois quando é excessiva, promove a deformação da amostra e em solo seco acarreta fissuras, dificultando a retirada de amostras.

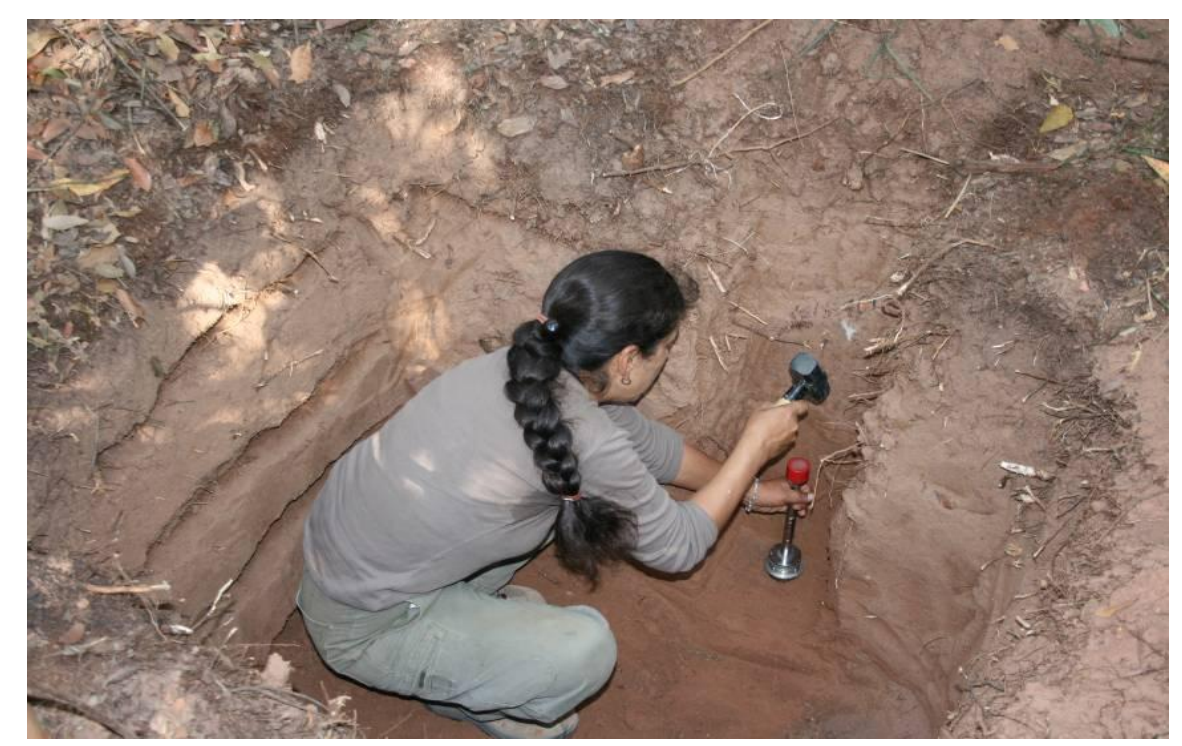

Foto 8: Amostragem a $80 \mathrm{~cm}$ de profundidade.

As amostras foram envolvidas em filme PVC para sua conservação. Como o susbtrato apresentava granulometria predominantemente arenosa e se encontrava muito seco, a superfície a ser amostrada teve que ser umedecida previamente para evitar que a amostra se desmanche e desmorone.

A abertura das trincheiras para a amostragem também permitiu a observação de aspectos como o crescimento de raízes e a profundidade em que elas se desenvolvem, podendo-se medir, ainda, a camada de serrapilheira no local e a profundidade em que se atingiu o material de substrato compactado.

\subsubsection{Observações da vegetação}

Para obtenção das informações da vegetação, em cada área foram selecionadas ao acaso 5 parcelas de $300 \mathrm{~m}^{2}$ (30 m x $\left.10 \mathrm{~m}\right)$ cada uma. Assim, era esperado um 
total de 25 parcelas de amostragem, uma vez que a área $A 6$ sem revegetação não foi amostrada por razões óbvias. Porém, durante a pesquisa, houve perda de informação dos dados da parcela 4 na área $A 4$, e na área A5 apenas duas parcelas foram observadas. Portanto, o estudo contém 21 parcelas. Em cada parcela, a área foi delimitada com barbante e as medições de altura foram feitas com uma vara demarcada com escala referencial. A circunferência à altura do peito (CAP) foi medida com fita métrica e, como critério de inclusão estabeleceu-se que devem ser medidos e incluídos todos os indivíduos arbóreos que apresentem CAP igual ou maior a cinco centímetros.

Para o reconhecimento das espécies arbóreas contou-se com a ajuda de um "mateiro", com grande experiência na identificação das espécies vegetais locais. Houve dificuldades por ser um processo visual no qual nem sempre foi possível identificar corretamente o nome da espécie. É o caso de algumas árvores caducifólias que, na época de amostragem, não apresentavam folhas. Em outras situações foi necessária a montagem de exsicatas para identificação posterior por meio de recursos auxiliares consulta bibliográfica ou técnica. Um aspecto que se observou com atenção redobrada foi o surgimento espontâneo de mudas arbóreas.

Após a coleta dos dados, foi constatado que as parcelas onde foram coletadas as variáveis de vegetação não eram coincidentes com as áreas selecionadas para a coleta de informações de solo (trincheiras). Tanaka et al. (2009) manifestam que esse fato pode ser um limitador na análise inferencial que pretende relacionar as características físicas e químicas do solo levando-se em conta a vegetação do local. Uma forma encontrada para viabilizar a análise inferencial citada foi verificar qual trincheira estava mais próxima de cada parcela dentro de cada área. Nessa associação entre trincheiras e parcelas é possível que algumas parcelas sejam perdidas ou ainda, que algumas trincheiras apareçam com maior freqüência que outras. Para fins práticos os autores recomendam estabelecer as parcelas dentro ou muito próximas das trincheiras.

\subsubsection{Ensaios de laboratório}

Os ensaios de laboratório objetivam o levantamento das variáveis selecionadas e a obtenção de dados numéricos por meio de procedimentos 
convencionais ou adaptados segundo as necessidades do trabalho. Os dados obtidos servirão para análise e interpretação das variáveis.

O intuito é realizar a apreciação criteriosa das variáveis que possam refletir com maior clareza as mudanças ocorridas ao longo do tempo, de maneira que possam constituir indicadores de desempenho da recuperação das áreas degradadas revegetadas.

Com esta finalidade procedeu-se à remessa de parte das amostras ao Laboratório de Fertilidade de Solos da ESALQ-USP para análise química de fertilidade conforme as metodologias descritas no item 2.3.5. As análises de densidade de solo e granulometria foram realizadas no Laboratório de Mecânica de Solos da Escola Politécnica-USP, segundo as metodologias descritas nos itens 2.3.1 e 2.3.4, respectivamente. A determinação da densidade de partícula faz parte da rotina de determinação de granulometria. A determinação da porosidade é calculada a partir dos dados de densidade do solo.

\subsection{Caracterização do substrato na bacia de rejeitos}

No processo de recuperação da área da bacia, uma vez depositado o rejeito, houve uma fase que consistiu na evaporação de parte da água contida até atingir determinado grau de adensamento. Na seqüência, foi distribuída uma camada de material arenoso, considerado pela mineração como material estéril. Como a profundidade desta camada de areia não era conhecida, tomou-se a decisão de abrir algumas trincheiras de reconhecimento (antes da abertura das trincheiras das amostragens propriamente ditas), com o intuito de avaliar a sua profundidade e sua uniformidade ao longo do perfil. Conforme comentado na seção 3.2.1, devido à ausência de registros deste procedimento operacional, não existem detalhes desta informação, apenas lembranças na memória das pessoas envolvidas; ademais, houve mudança das pessoas mais antigas que trabalharam diretamente nestas ações, uma situação comum em empresas de mineração. A foto 9 mostra a bacia quando o rejeito ainda estava sendo depositado em seu interior. 


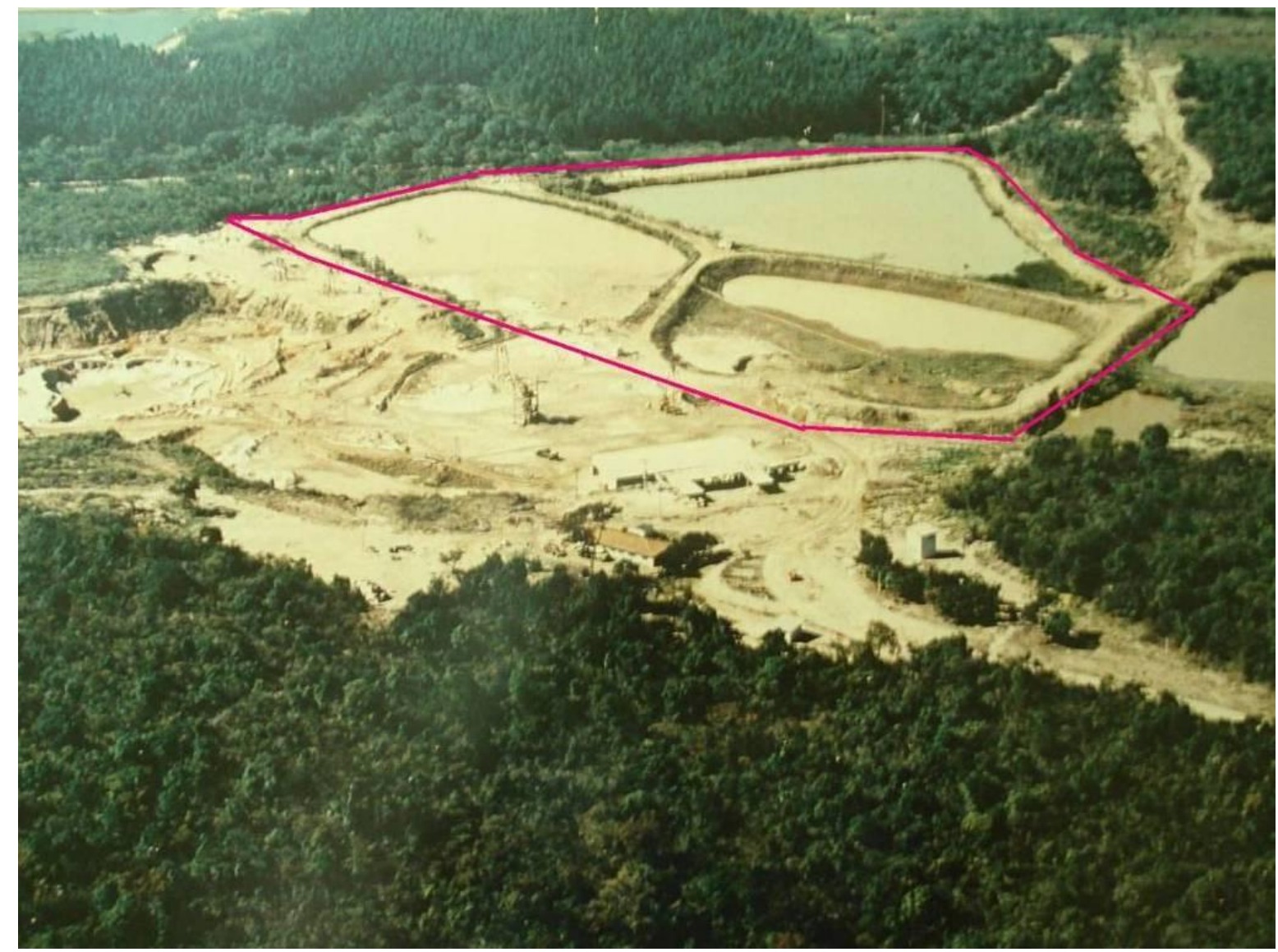

Fonte: Mineração Descalvado.

Foto 9: Situação geral da bacia de rejeito (contorno em vermelho) antes do ano 1995.

$\mathrm{Na}$ foto 10 pode-se apreciar a bacia no ano 2007, já com vegetação implantada. Aparentemente a vista aérea mostra uma vegetação uniforme, mas o plantio foi feito por etapas. A demarcação das áreas por idade de revegetação irá permitir observar as possíveis diferenças, tanto no crescimento das plantas, como na evolução da recuperação do substrato. 


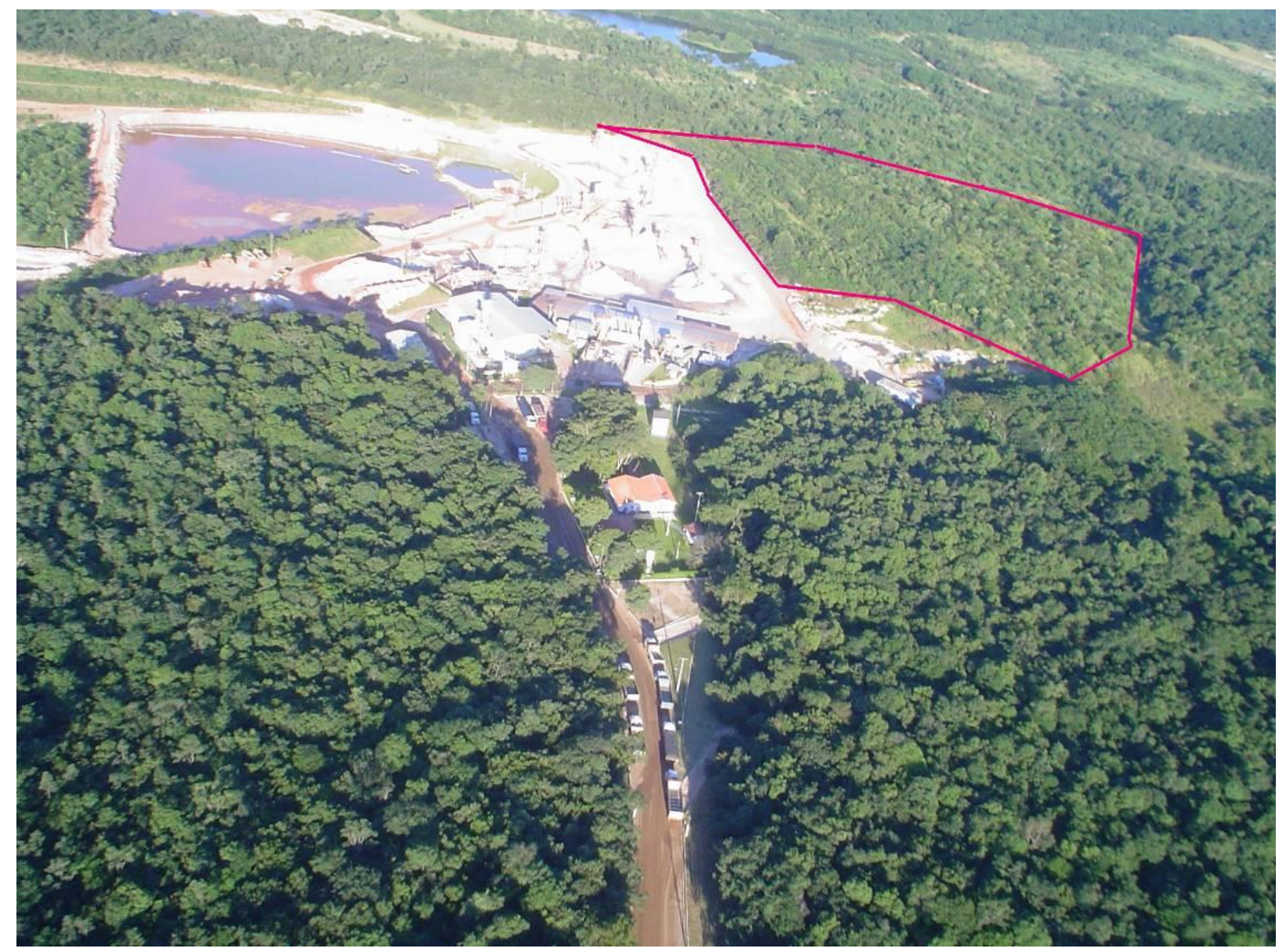

Fonte: Mineração Descalvado

Foto 10: Vista aérea da Mineração Descalvado (2007), com destaque para a antiga bacia de rejeitos já revegetada (contorno em vermelho). Em primeiro plano, a vegetação nativa remanescente.

As cinco trincheiras de reconhecimento abertas nas áreas revegetadas priorizaram a abertura de ao menos uma delas por cada área com diferente idade de revegetação. A profundidade atingida foi de 1,8 a $2 \mathrm{~m}$.

Observou-se que o substrato ao longo dos perfis contém material predominantemente arenoso com consistência dura e compactada até uma profundidade variando de 20 a $70 \mathrm{~cm}$, abaixo do qual se encontra um material extremamente duro e cimentado que continua com estas características até a profundidade de $1,80 \mathrm{~m}$, limite imposto pela dificuldade extrema de escavação manual das trincheiras (Foto 11). 

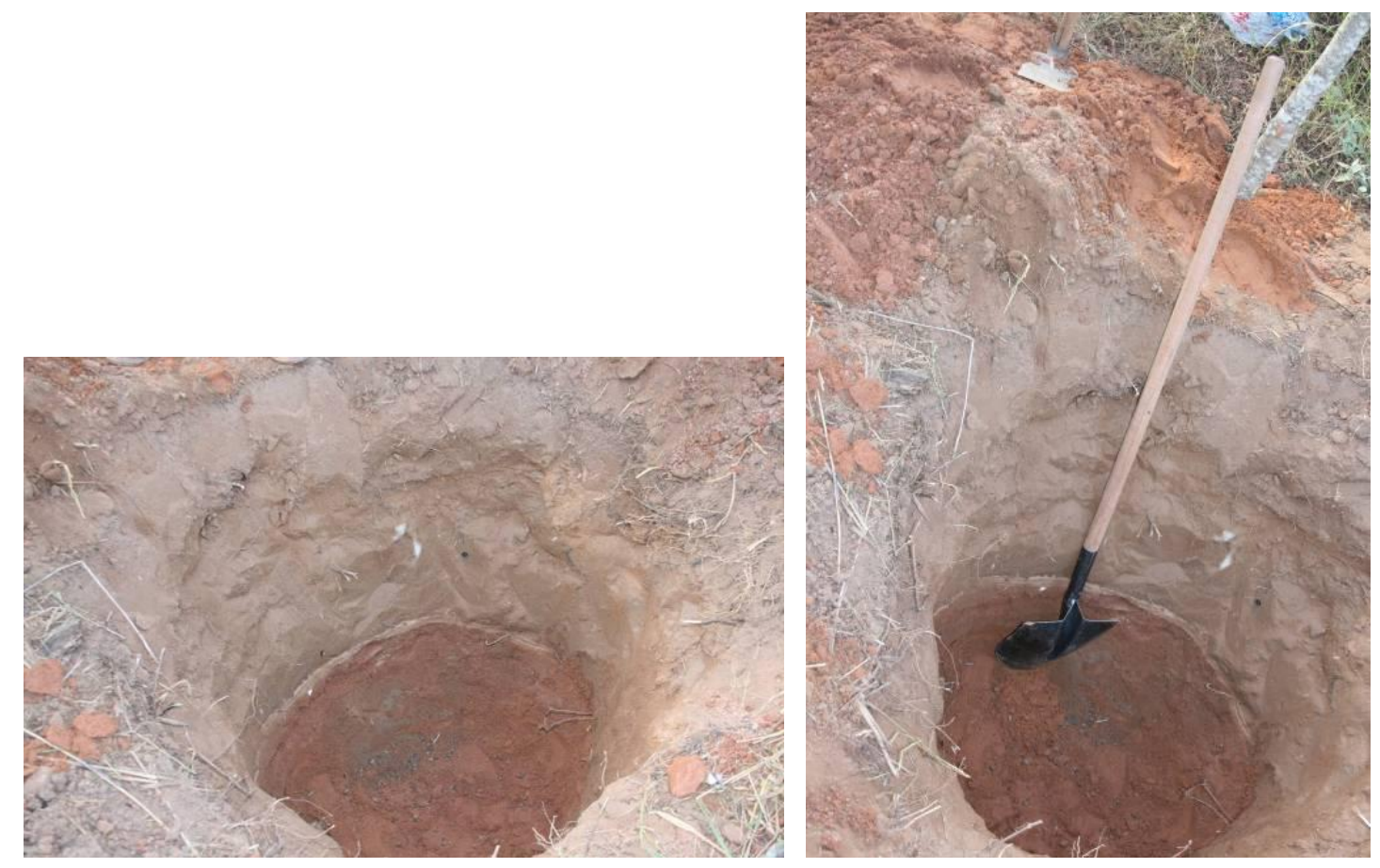

\section{Foto 11: Trincheiras apresentando material muito compactado na profundidade média de $60 \mathrm{~cm}$.}

Em nenhum dos casos se atingiu o material mais fino, característico do rejeito. Quando o material arenoso de preenchimento da bacia é colocado acima do rejeito, este encontra-se na forma de uma lama com muita umidade. A mistura do estéril arenoso com o rejeito silto-argiloso, deve resultar no material duro e compactado, como o que se observou no fundo das trincheiras. Com relação a esta possibilidade, Vargas (1977) descreve a situação de uma camada de argila sedimentando em água em que a adição de outra camada exerce a ação do peso distribuindo-lhe uma determinada pressão. Essa pressão levará a camada de argila a comprimir-se, diminuindo seus vazios ou, provavelmente, invadindo os espaços porosos da camada arenosa adicionada no substrato em estudo. O autor acrescenta que a estrutura ou arranjo de partículas resultará mais compacta ainda pela ação da água, que serve de elemento de ligação entre os grãos. À medida que a água vai sendo expulsa, o volume dos espaços entre grãos vai diminuindo; nessa situação o autor utiliza o termo coeso ou adensado. Oliveira et al. (2002) utilizam o termo consolidação para o processo que decorre também da compressão, porém causada por um peso estático, acompanhado por lenta expulsão de água do solo quando 
este se encontra saturado. Para esses autores, a coesão é decorrente dos processos de consolidação e compactação.

$\mathrm{Na}$ situação da bacia em estudo, o rejeito, ao ser misturado com o estéril arenoso, produz pressões pelo peso, o que gera passagem do material fino em suspensão para a camada arenosa, provocando obstrução dos macroporos com conseqüente diminuição da permeabilidade e do espaço poroso. Com o tempo, provavelmente, a perda de umidade gera a forte compactação observada, que se assemelha a um aspecto de cimentação. Os altos teores de óxidos de ferro e alumínio presentes no rejeito (Ferreira \& Daitx, 2003) possuem baixa superfície específica, situação que confere a estas substâncias características cimentantes (Oliveira et al, 2002).

Quanto às raízes, observou-se um crescimento mais ativo nos primeiros 40 $\mathrm{cm}$ do solo. Abaixo dos $60 \mathrm{~cm}$ não se observou a presença de enraizamento, com exceção de uma trincheira na qual houve alguma presença de raízes muito finas até próximo de $60 \mathrm{~cm}$ de profundidade (Foto 12).
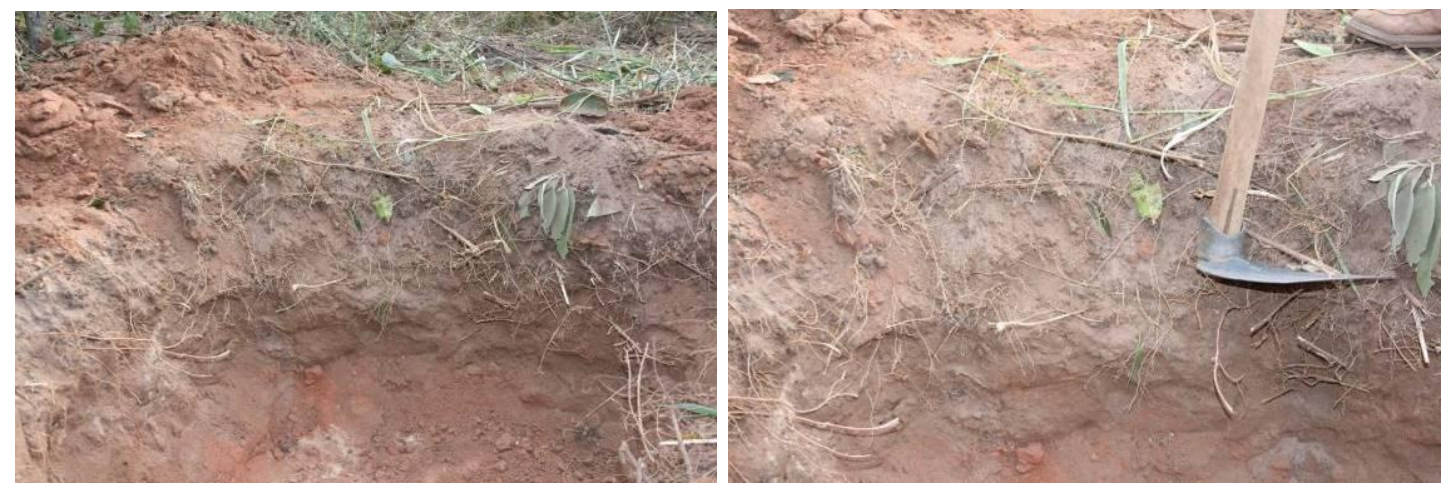

Foto 12: Profundidade de raízes em torno dos $40 \mathrm{~cm}$ de profundidade.

Até a profundidade de 1,80 m não se atingiu o material de rejeito mais fino de forma isolada. Observou-se que as raízes da vegetação implantada se intensificam em torno dos $40 \mathrm{~cm}$ de profundidade. Abaixo de $70 \mathrm{~cm}$ de profundidade não se encontraram vestígios de raízes ou de outro material vegetal. Por tais motivos, o estudo concentrou-se na observação do estado do substrato e da vegetação nessa camada em que ambos se inter-relacionam, ou seja, até o máximo de $100 \mathrm{~cm}$, 
descartando-se a investigação do estado do substrato que está abaixo desta profundidade.

\subsection{Caracterização das áreas de estudo}

Apresenta-se uma descrição das características mais relevantes da vegetação e do estado do substrato encontrados em cada área de estudo. A abertura das trincheiras definitivas em cada área permitiu realizar as amostragens, além de se observar aspectos do substrato em sub-superfície tais como a profundidade do crescimento das raízes, seu modo de desenvolvimento, mudanças na cor do substrato, macrofauna ou mesofauna existentes, espessura da camada de serrapilheira e, também, a profundidade do início da camada de compactação.

\subsection{1 Área $\mathrm{A} 1$}

Esta área foi revegetada há, aproximadamente, quatorze anos (comunicação verbal) ${ }^{4}$, e está situada na encosta sudeste da bacia que margeia a zona de construção do dique da mesma, apresentando certa declividade. O substrato amostrado na superfície tem consistência muito solta e houve necessidade de umedecer o solo para extrair as amostras indeformadas evitando, assim, o demoronamento. O substrato se encontra solto e arenoso na parte superior e a partir dos $70 \mathrm{~cm}$ de profundidade há alguma dificuldade para a penetração do amostrador (Foto 13). Como esta área corresponde à zona de construção do dique, não se observou material cimentado ao longo do perfil das trincheiras abertas. A zona do dique da bacia corresponde à sua área marginal, na qual, é usual depositar material argiloso compactado com o propósito de conter o material que irá ser depositado na bacia. ${ }^{5}$

\footnotetext{
${ }^{4}$ Fornecida pela gerência da mina em $08 / 08$

${ }^{5}$ Informação pessoal do Prof. Dr. Lindolfo Soares, docente no Depto. de Engenharia de Minas e de Petróleo - EPUSP.
} 

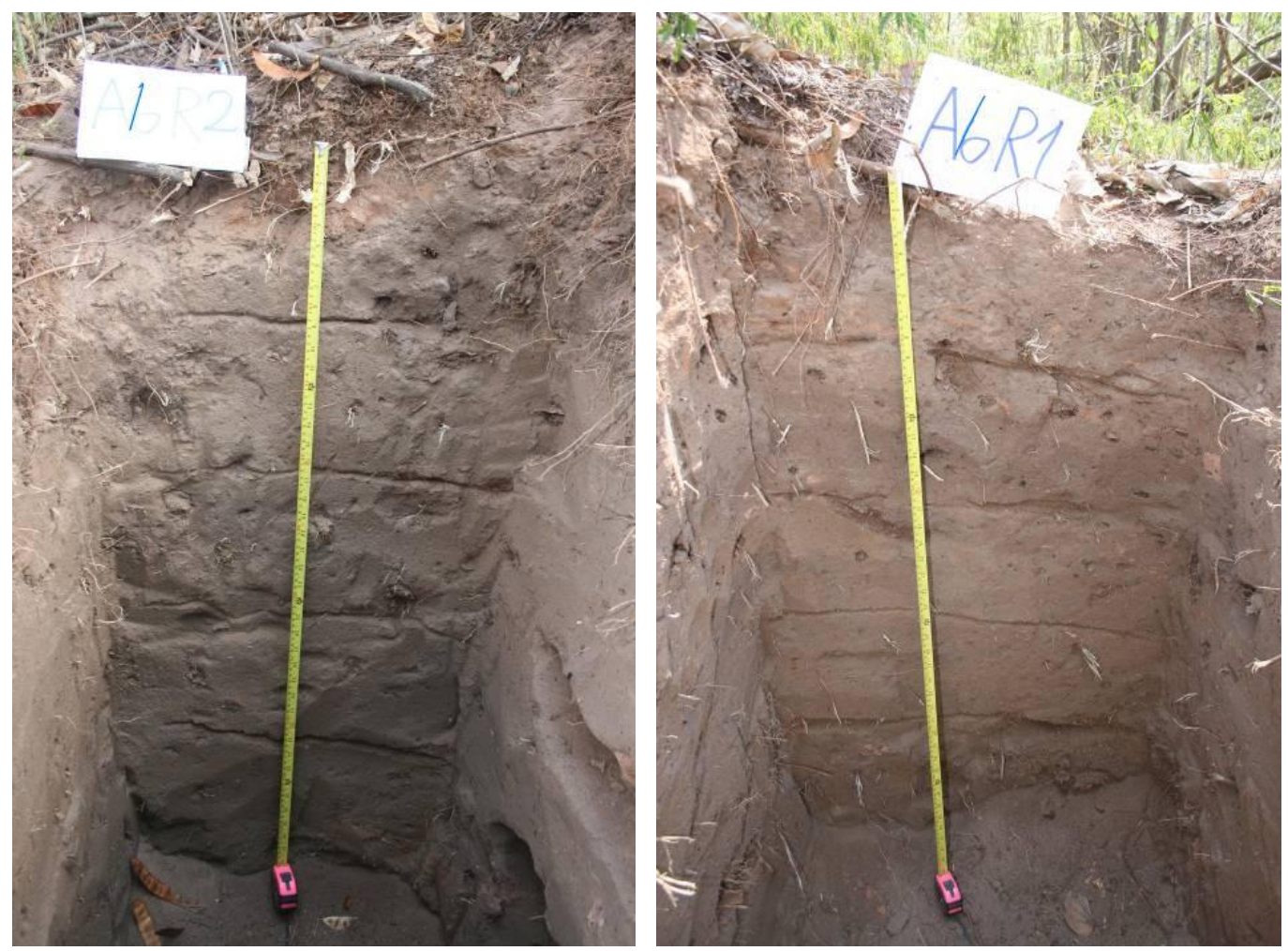

Foto 13: Perfis representativos do substrato na Área A1.

A revegetação nesta área foi realizada em 1995, as espécies arbóreas adultas apresentam alturas entre 2,5 e 8,5 m, sendo que individuos das espécies de Adenanthera falcata (Angico cascudo), Acacia poliphylla (Monjoleiro), e Croton floribundus (Capixingui) detêm os maiores desenvolvimentos. Há presença de grande quantidade de mudas $($ CAP $<5)$ com tamanhos variados de Acacia poliphylla brotando naturalmente (Foto 14). Embora com menor frequência, também há muitas mudas de Croton floribundus e Jacaranda micrantha (Caroba) crescendo nas áreas sombreadas. Mudas de outras espécies brotando isoladas podem ser apreciadas na Tabela 27, mas destaca-se a presença de indivíduos das espécies nativas Copaifera langsdorffii (Copaíba), Mabea fistulífera (Canudo de pito) e Ocotea pulchella (Canela) regenerando naturalmente, sem a presença de indivíduos plantados na área, o qual reflete algum tipo de dispersão de sementes vindas de matas próximas. $O$ Apêndice $A$ lista as espécies arbóreas identificadas em cada área. 
A Brachiaria decumbens (Capim braquiária) tem crescimento ativo em locais mais abertos, onde as árvores estão mais espalhadas ou têm menor crescimento, enquanto que, nas áreas mais sombreadas quase não se observa a presença de herbáceas com exceção de cipó timbó. A camada de serrapilheira tem em média 5 $\mathrm{cm}$ de espessura e as raízes têm presença marcante entre os $60 \mathrm{~cm}$ a $80 \mathrm{~cm}$ de profundidade no perfil das trincheiras. Note-se que o desenvolvimento de raízes nesta área é mais profundo, pois o local, sendo a zona do dique, não contém o material fino de rejeito e, portanto também não apresenta camada compactada.

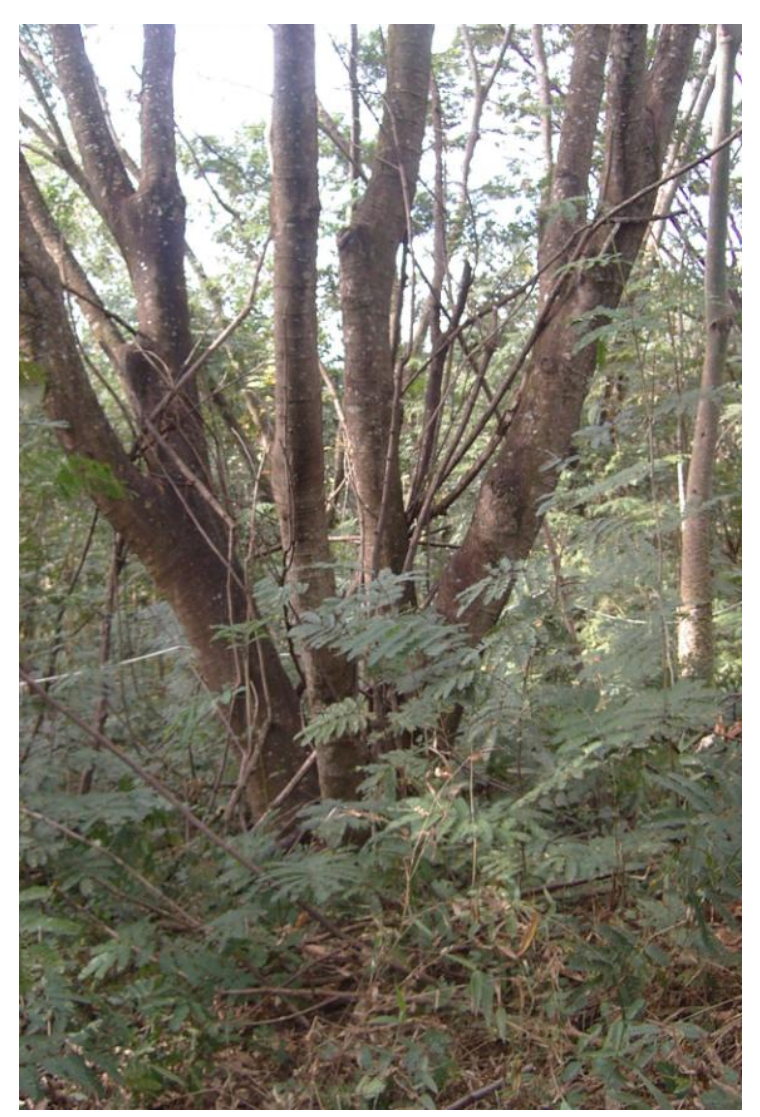

Foto 14: Detalhe de mudas emergentes de Acacia poliphylla, (Monjoleiro) na área $\mathbf{A 1 .}$ 

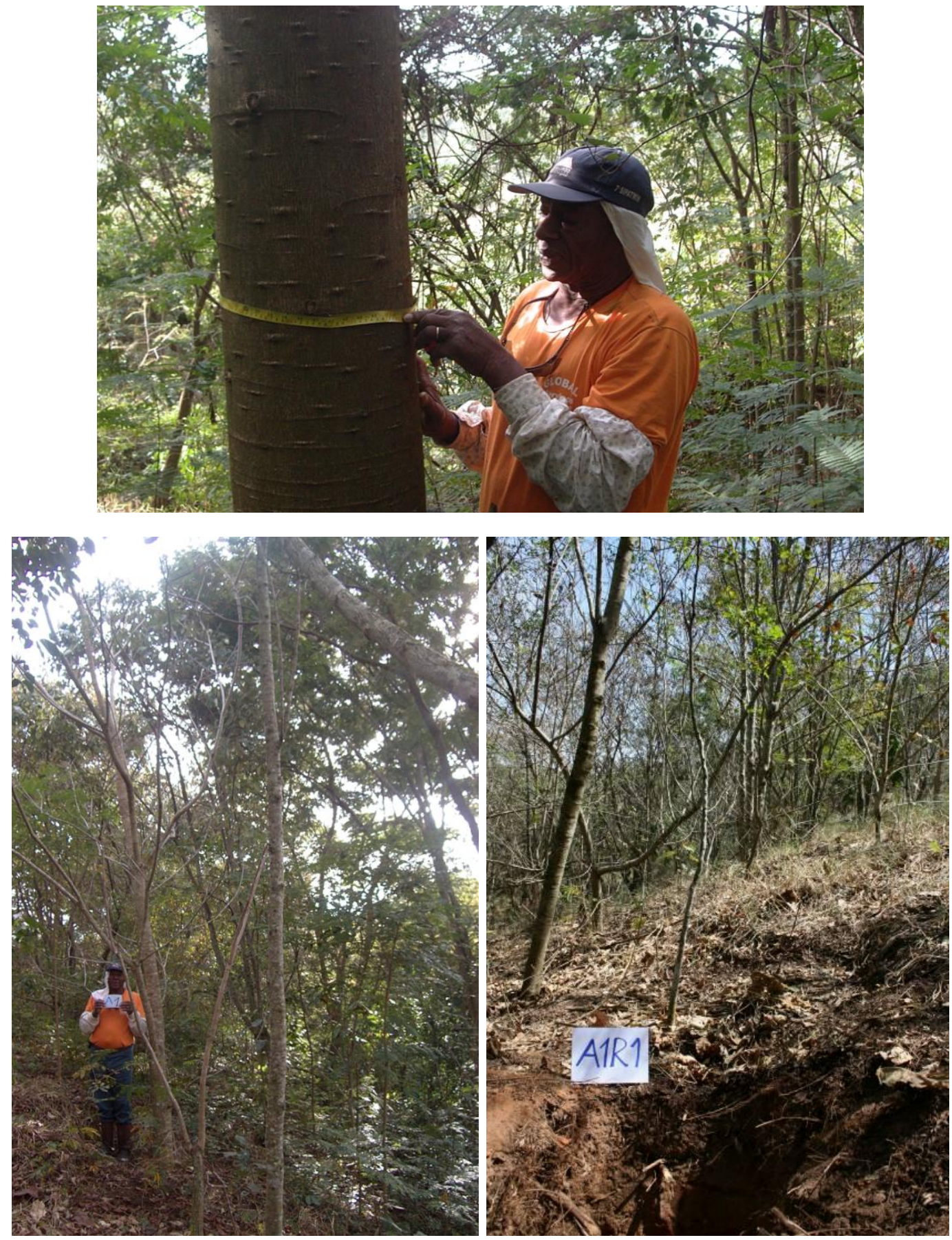

Foto 15: Estado geral da vegetação da Área A1 (conjunto). 


\subsection{2 Área A2}

Corresponde à revegetação realizada em 1998, e, portanto está com onze anos de idade. Neste local houve muita dificuldade para abrir as trincheiras, pois o substrato apresentou-se compacto desde a superfície, que estava muito seca, dificultando também a obtenção de amostras indeformadas e tendo-se que aplicar mais de duzentas percussões manuais. O problema foi contornado com a adição de água no local de amostragem, um dia antes da abertura das trincheiras. Esse comportamento diminuiu levemente com a profundidade, pois o substrato já se encontrava com certa umidade. Observou-se, de forma atípica, uma camada fina de pedrisco $(60 \mathrm{~cm})$ em uma das trincheiras.
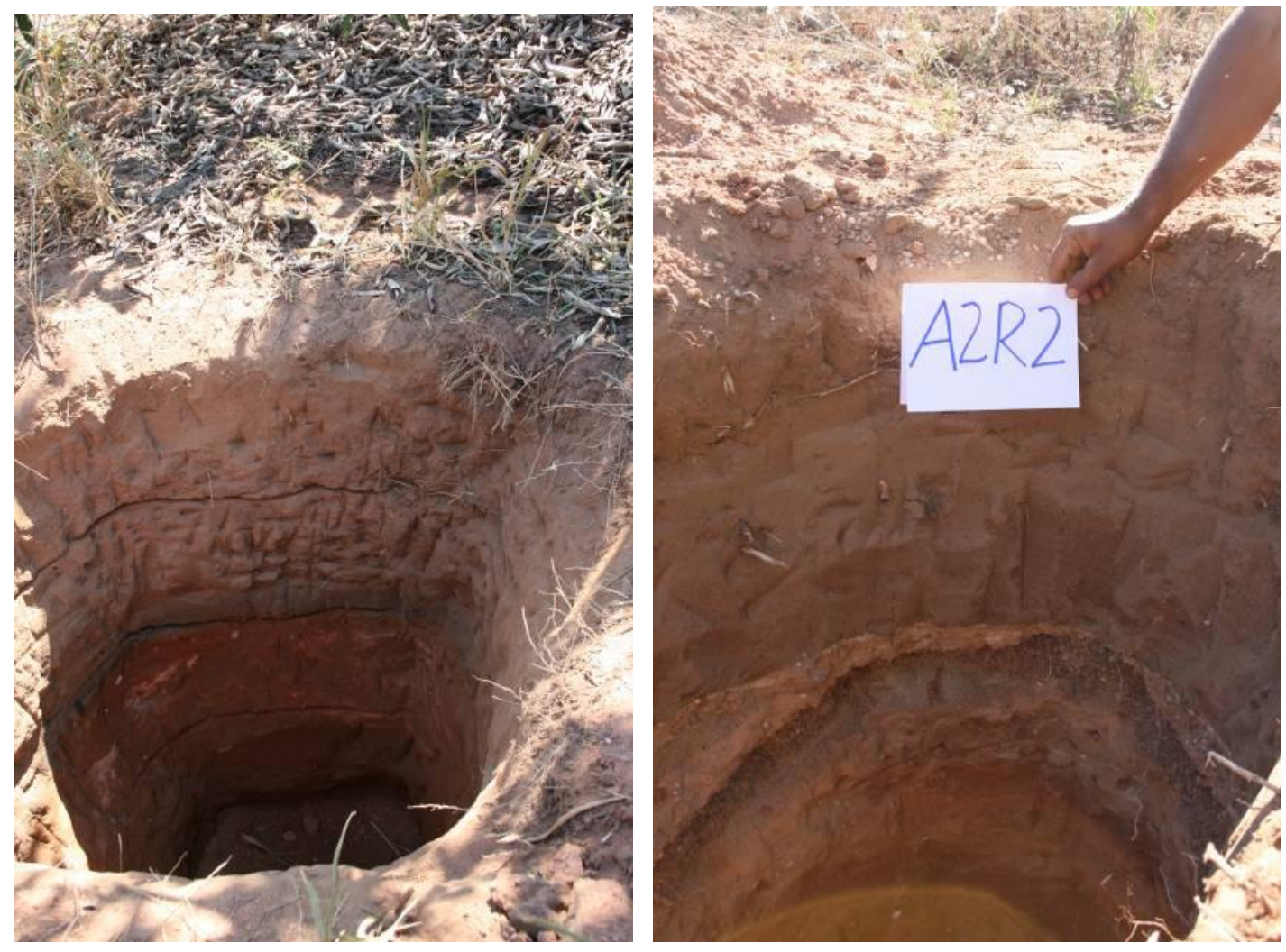

Foto 16: Perfis representativos do substrato na Área A2. 
Em alguns espaços a superfície do solo não apresenta cobertura vegetal. Como conseqüência, a espessura da camada de serrapilheira é mínima, apenas de $1 \mathrm{a} 2 \mathrm{~cm}$ ou inexiste em alguns trechos. A presença de raízes é mais densa até os $20 \mathrm{~cm}$, mas observam-se algumas poucas raízes que atingem até $40 \mathrm{~cm}$ (Foto 17).

As espécies arbóreas apresentam alturas entre $1,5 \mathrm{~m}$ e $6,5 \mathrm{~m}$, mas no dossel onde a maioria das árvores atinge os $4 \mathrm{~m}$, se distinguem os indivíduos das espécies Adenanthera macrocarpa (Angico vermelho) e Enterolobium contortisiliqum (Timburí) com desenvolvimento vigoroso e muito superior ao resto. Na superfície há crescimento intenso de capim braquiária. Outra herbáceas crescendo espontaneamente são Andropogon leucostachys (capim Rabo de burro) e Bidens pilosa (Amor seco). Identifica-se pouco crescimento de espécies arbóreas regenerantes, com indivíduos isolados das espécies Schinus terebentifolius (Aroeira pimenteira), Acacia poliphylla (Monjoleiro), Baccaris dracunculifolia (Alecrim-docampo) e Vernonia polyanthes (Assa-peixe), estas duas últimas provenientes de dispersão de sementes. Observou-se claramente o pouco desenvolvimento que tiveram algumas espécies plantadas como o Aspidosperma sp. (Jatobá), Tabebuia cassineoides (Ipê amarelo), e Hymenaea stigonocarpa (Peroba rosa) que em muitos casos não atingiram a CAP de $5 \mathrm{~cm}$. A espécie Mimosa caesalpinefolia (Sansão do campo) também apresentou muitos indivíduos com CAP menor que $5 \mathrm{~cm}$, neste caso, eles foram plantados posteriormente, como uma medida para melhorar as condições do substrato. Árvores de Croton floribundus (Capixingui) e Psidium gojaba (Goiaba) apresentaram grande quantidade de rebrotamento. 

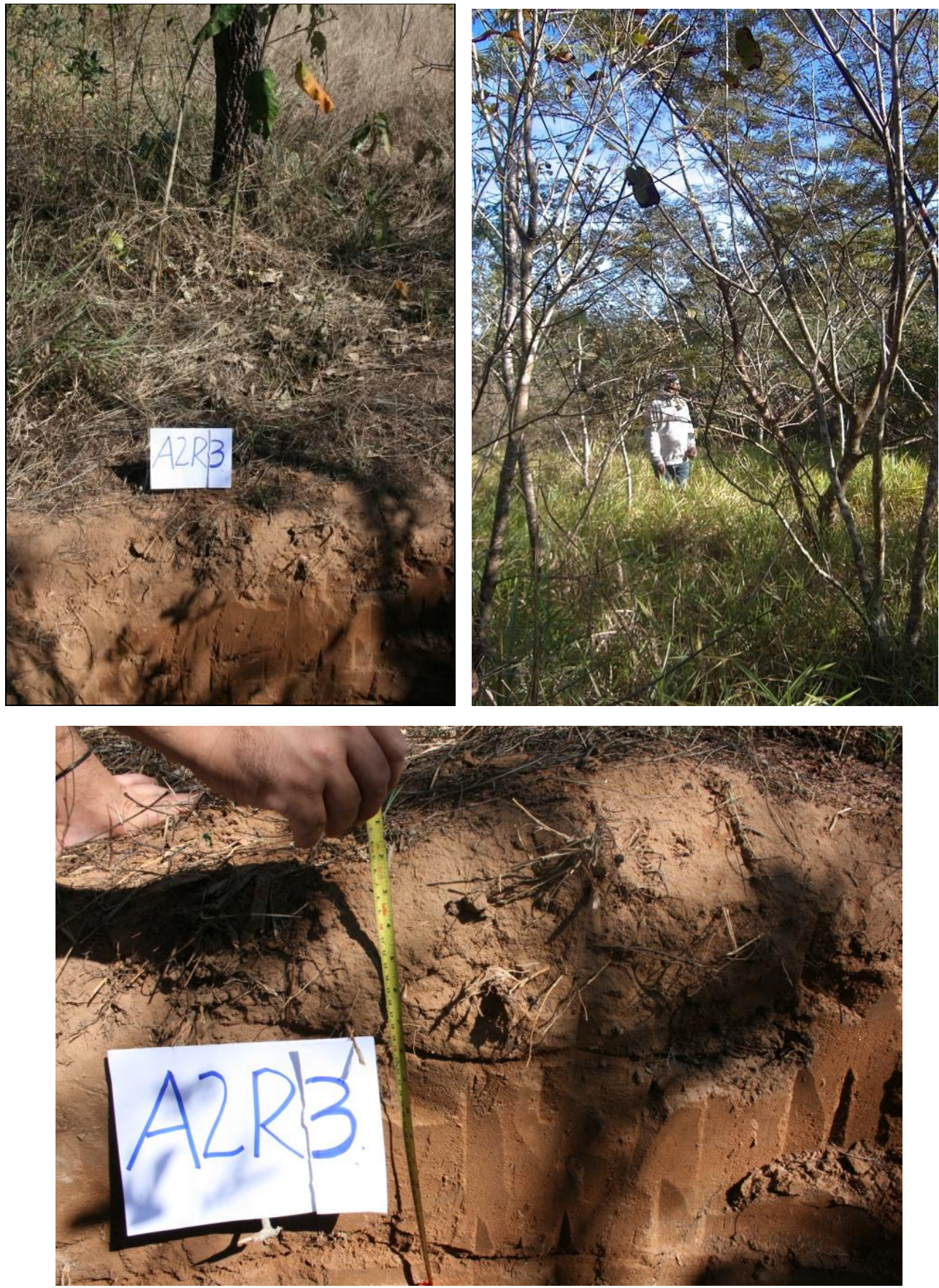

Foto 17: Detalhes da vegetação e do substrato na Área A2 (conjunto). 


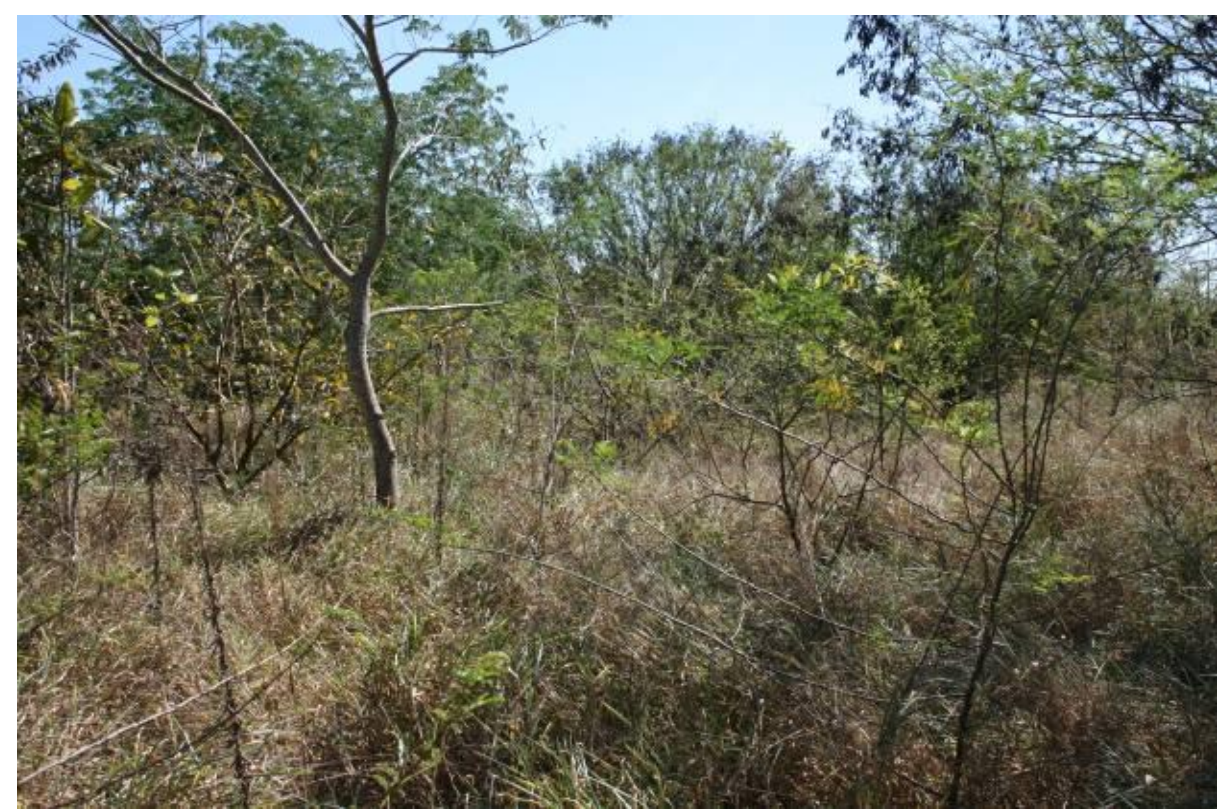

Foto 18: Vista geral da vegetação da Área A2 (11 anos).

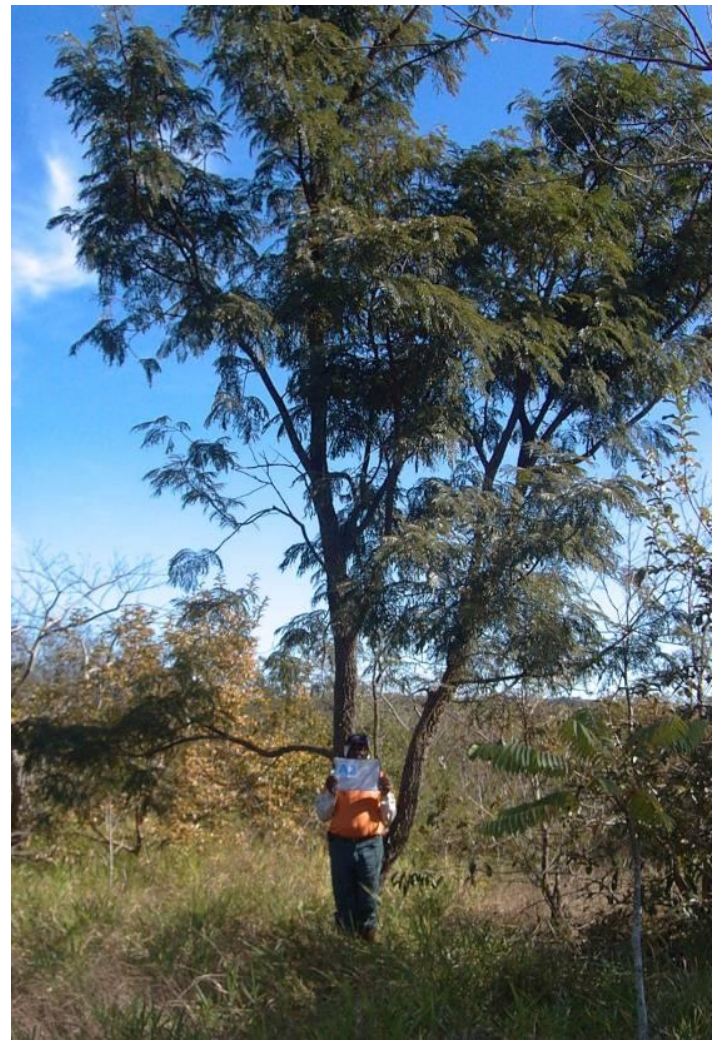

Foto 19: Detalhe do crescimento diferenciado do Adenanthera macrocarpa (Angico vermelho) na Área A2. 


\subsection{3 Área A3}

Esta área foi revegetada em 2001. Desde a superfície até $40 \mathrm{~cm}$ de profundidade, o substrato apresentava consistência solta e boa presença de raízes, o que facilitou a amostragem. A dificuldade de escavação e amostragem começou entre $40 \mathrm{~cm}$ e $60 \mathrm{~cm}$ de profundidade quando o substrato muda para uma consistência dura e cimentada. Houve também uma mudança na cor do substrato de marrom escuro para marrom bem mais claro (Foto 20).
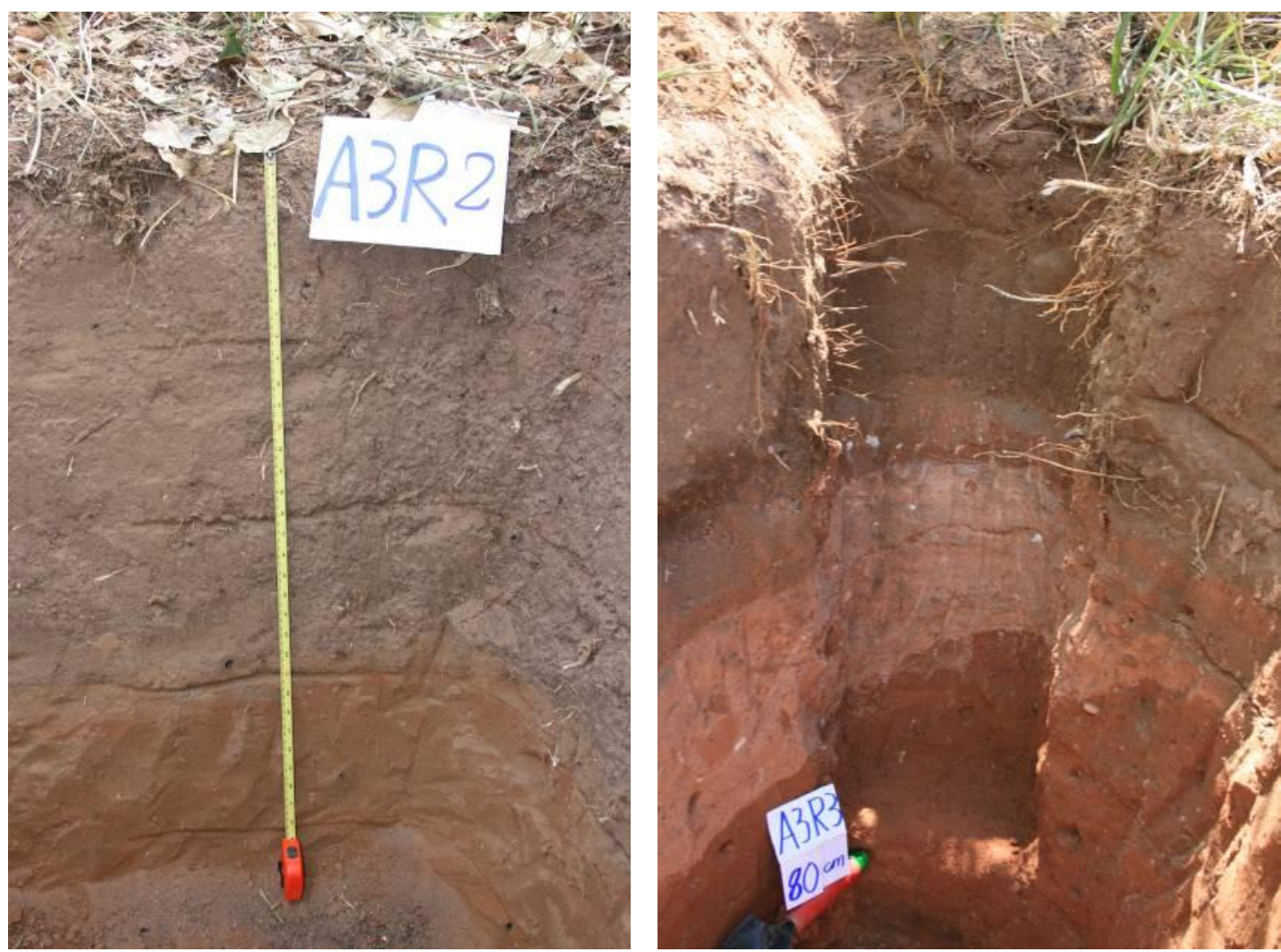

Foto 20: Perfis representativos do substrato da Área A3.

O crescimento das raízes é mais ativo nos primeiros $40 \mathrm{~cm}$ e diminui por completo abaixo dos $60 \mathrm{~cm}$. A camada de serrapilheira apresenta $3 \mathrm{~cm}$ de espessura em média. As espécies arbóreas têm alturas entre 3 e $8 \mathrm{~m}$ de altura com 
alguns individuos das espécies Acacia polyphilla (Monjoleiro) e Peltophorum dubium (Canafístula) que atingem até $10 \mathrm{~m}$. Embora esta área também apresente capim braquiária nos locais mais abertos, seu crescimento não é tão denso e há maior diversificação de espécies herbáceas como o Andropogon leucostachys (Capim Rabo de burro), o capim Elefante, as nativas grama Bambuzinho, Solanum lycocarpum (Juá bravo), cipó Timbó, Cyperus sp. (cipó Navalha de mico), a bromélia terrestre Caraguatá e até a orquídea terrestre Oeceoclades maculata. Plantas adultas e mudas da nativa Solanum mauritanum (Fumo bravo) se observam com certa frequência, sendo que não houve indivíduos plantados desta espécie na área. Outras espécies nativas surgindo naturalmente em menor quantidade são Vernonia polyanthes (Assa-peixe), Xylopia aromatica (Pindaíba de macaco), mostrada na Foto 21, Baccaris dracunculifolia (Alecrim-do-campo), Guazuma ulmifolia (Guaxumá branco). Também se observam mudas de Jacaranda micrantha (Caroba) e Acacia polyphilla (Monjoleiro). Numa das parcelas amostradas nesta área se observou grande quantidade de indivíduos de Inga edulis (Ingá) e corresponde a um local alagadiço onde propositalmente se plantou mais individuos desta espécie pela sua tolerância à umidade. ${ }^{6}$

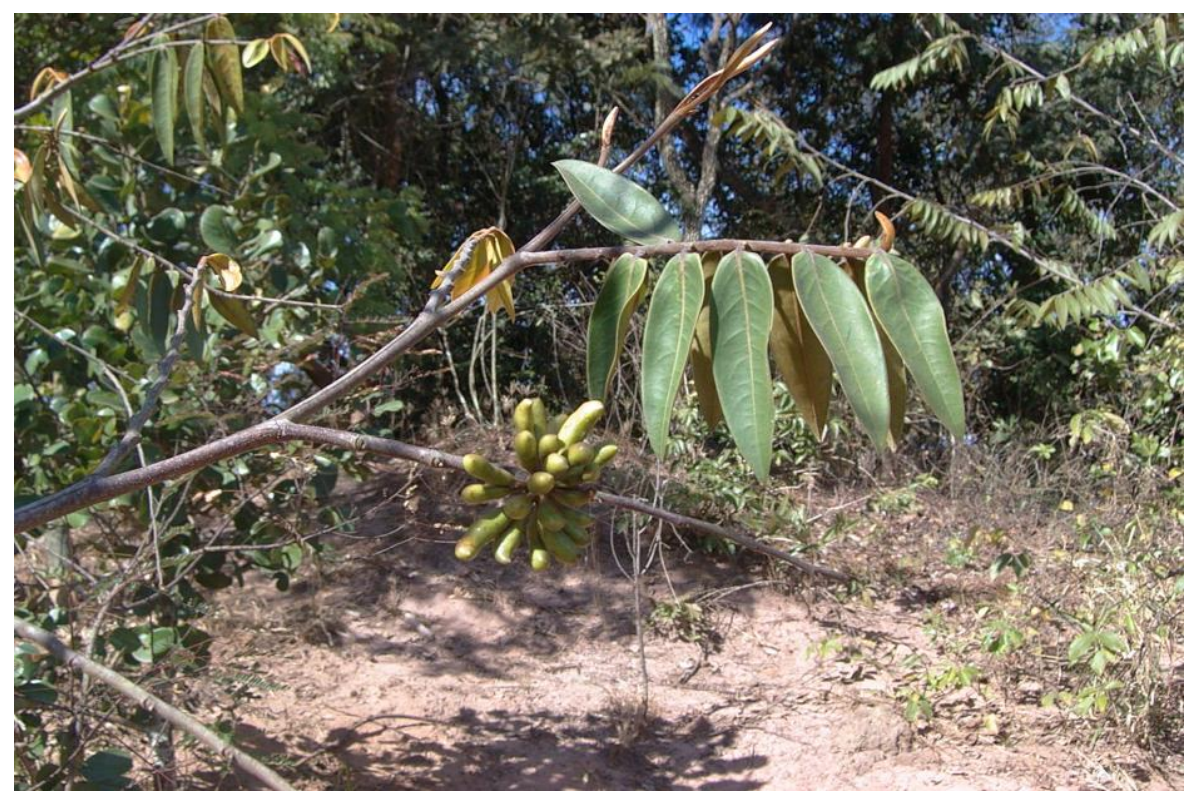

Foto 21: Detalhe da espécie arbórea nativa Xylopia aromatica (Pindaiba de macaco), colonizadora natural na Área A3.

\footnotetext{
${ }^{6}$ Informação fornecida pelo Sr. Antônio, Mateiro e funcionário que participou da revegetação na época.
} 

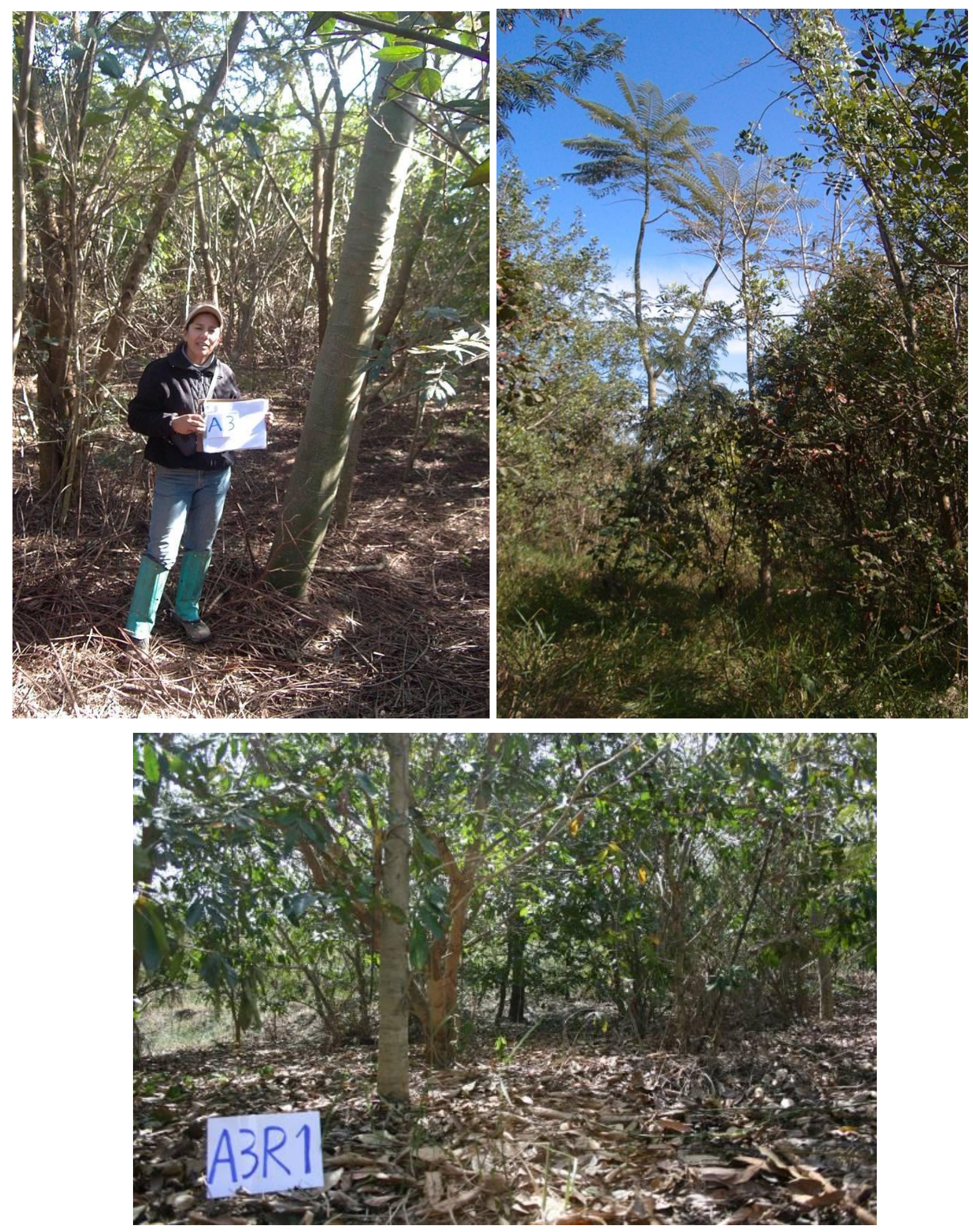

Foto 22: Estado geral da vegetação da Área A3 (conjunto). 


\subsection{4 Área A4}

Esta área foi revegetada mais recentemente, em 2003. Nas trincheiras abertas, o substrato da superfície se mostrou muito solto. As amostras obtidas no cilindro desmanchavam com facilidade, dificultando a coleta. Por esta razão foi necessário umedecer previamente a superfície, de maneira a realizar a amostragem sem comprometer o volume da amostra. A partir de $30 \mathrm{~cm}$ de profundidade encontra-se a camada dura e compacta que dificulta a abertura de trincheiras e a amostragem (Foto 23). A existência de certa umidade no substrato, a partir de 70 $\mathrm{cm}$, amenizou o trabalho. Observou-se a presença atípica de uma camada fina de areia aos $80 \mathrm{~cm}$, em uma das trincheiras.
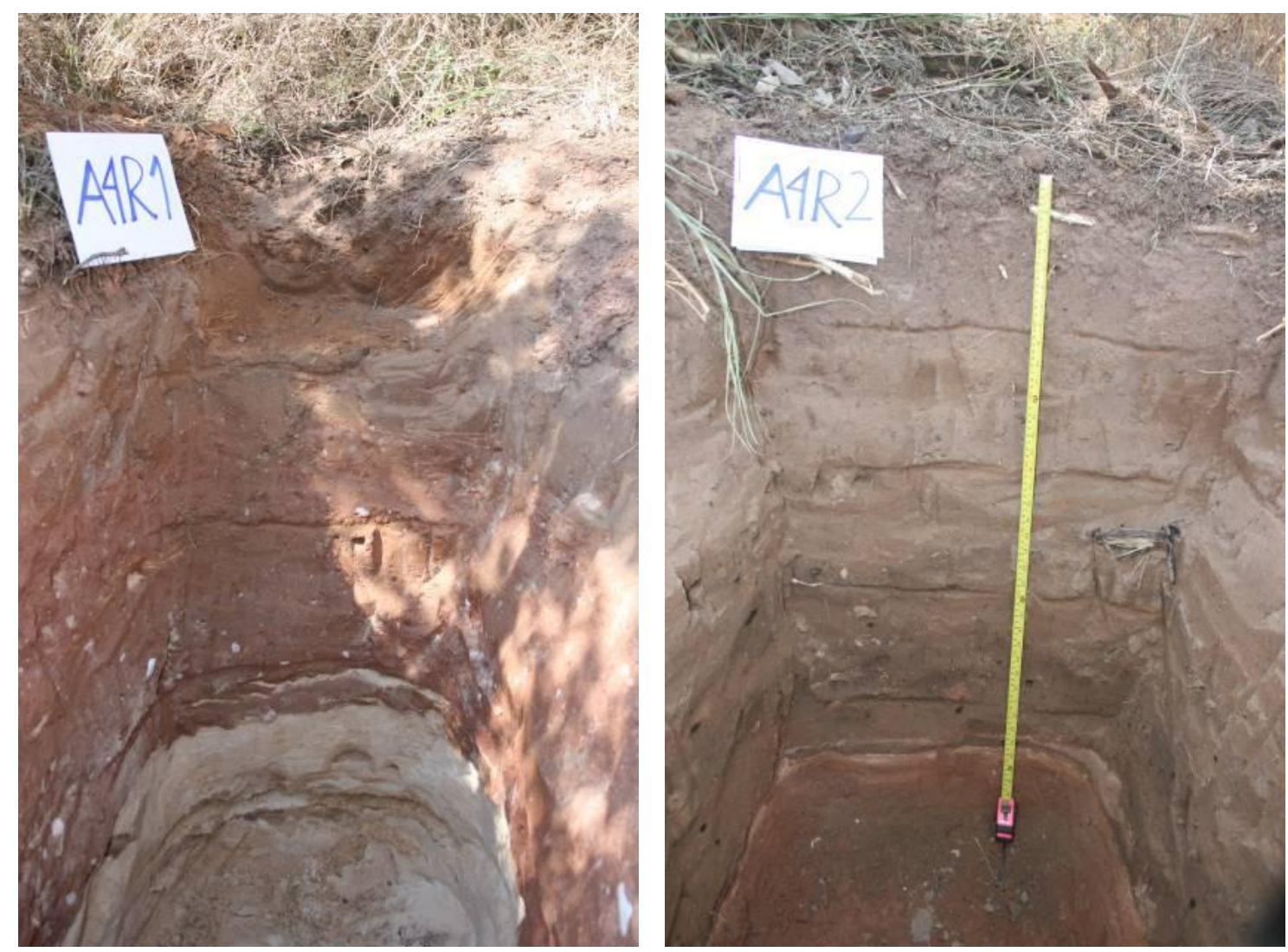

Foto 23: Perfis representativos do substrato na Área A4. 
A espessura média da camada de serrapilheira é de $3,5 \mathrm{~cm}$. A maior intensidade de enraizamento chega a $40 \mathrm{~cm}$, embora se observem algumas raízes grossas até os $60 \mathrm{~cm}$. Nesta área as árvores apresentam entre 2 e $7 \mathrm{~m}$ de altura, sendo que indivíduos das espécies Peltophorum dubium (Canafístula) e Acacia polyphilla (Monjoleiro) têm crescimento superior às outras espécies. O capim braquiária está presente, mas se mantém com porte baixo (Foto 24), permitindo o crescimento de outras herbáceas como Bidens pilosa (Amor seco), Eupathorium sp. (Alecrim-do-mato ou vassourinha) e Cyperus sp. (cipó Navalha de mico). A espécie plantada Pterogyne nitens (Amendoim) reporta, freqüentemente, indivíduos com CAP menor que cinco $\mathrm{cm}$, refletindo sua pouca resistência às condições do local. Foram observadas algumas mudas das espécies nativas de Xylopia aromatica (Pindaíba de macaco), Solanum mauritanum (Fumo bravo), Guazuma ulmifolia (Guaxumá branco) e de indivíduos regenerantes de Schinus terebentifolius (Aroeira pimenteira), Acacia polyphilla (Monjoleiro) e Jacaranda micrantha (Caroba). As listagens completas das espécies arbóreas identificadas em cada área podem ser conferidas no Apêndice A.

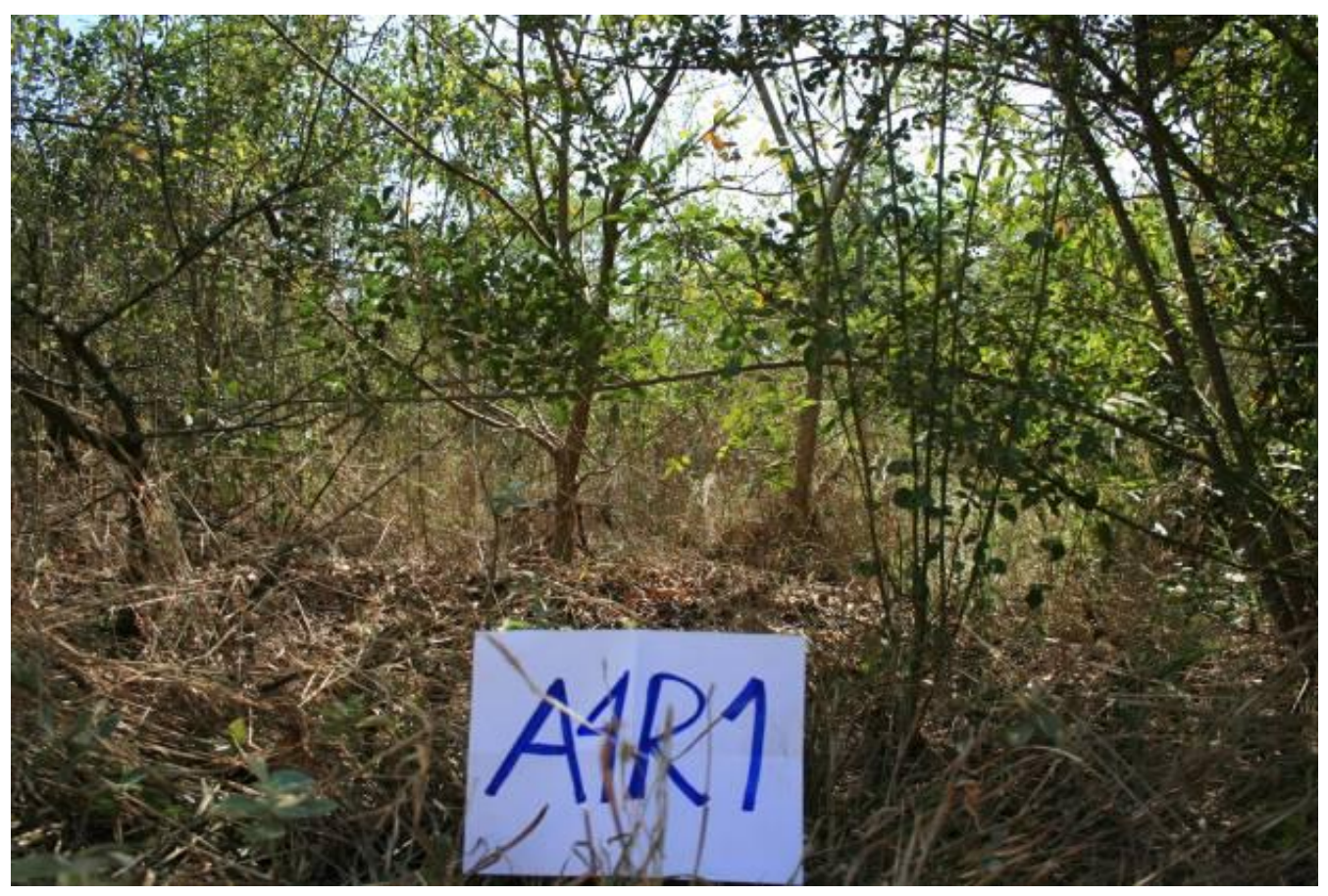

Foto 24: Detalhe da revegetação na Área A4 

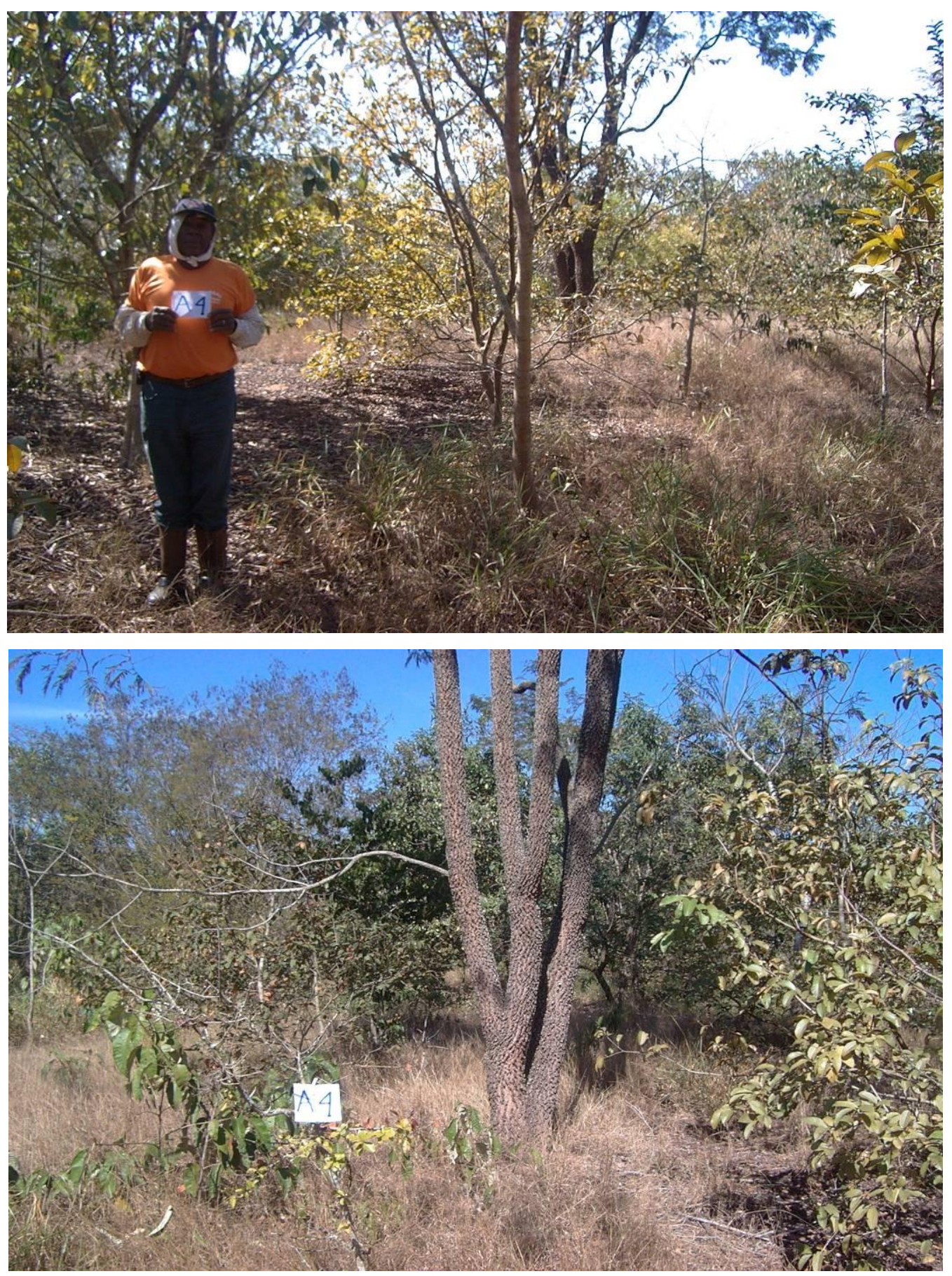

Foto 25: Estado geral da vegetação da Área A4 (conjunto). 


\subsection{5 Área A5 (Mata nativa)}

Área de floresta remanescente com aproximadamente 31 ha de extensão, coberta com vegetação nativa de Cerrado do tipo fisionômico vegetal Cerradão (PA BRASIL, 2008) e localizada ao norte da mineração. Os pontos de amostragens de solos e observação da vegetação distam de 600 a 900 m das áreas revegetadas em estudo.

A abertura das trincheiras (Foto 26) foi facilitada pela consistência solta e ausência de compactação do solo. A dificuldade enfrentada foram as raízes grossas das árvores que impediram a abertura das trincheiras e também a numerosa quantidade de raízes médias e finas, presentes até $1 \mathrm{~m}$ que foram um obstáculo à penetração do amostrador e dificultavam a retirada dos cilindros com o volume preservado. O solo nesta área é escuro, de textura arenosa, e se apresenta homogêneo ao longo do perfil. Para a amostragem na superfície houve necessidade de umidificação, o solo muito seco impossibilitava a obtenção da amostra indeformada, pois desmanchava com facilidade. Constatou-se que a umidade do solo aumenta com a profundidade e que é maior que nas áreas da bacia.

As observações das características do solo coincidem com as descritas por Lopes (1983) apud Carvalho (2008), que descreve os solos de Cerradão como portadores de boas propriedades físicas: boa aeração e permeabilidade, baixa densidade e baixa resistência à penetração. $O$ levantamento pedológico realizado pela PA Brasil (2008) nesta área aponta que o solo é classificado como Latossolo Vermelho-Amarelo. 

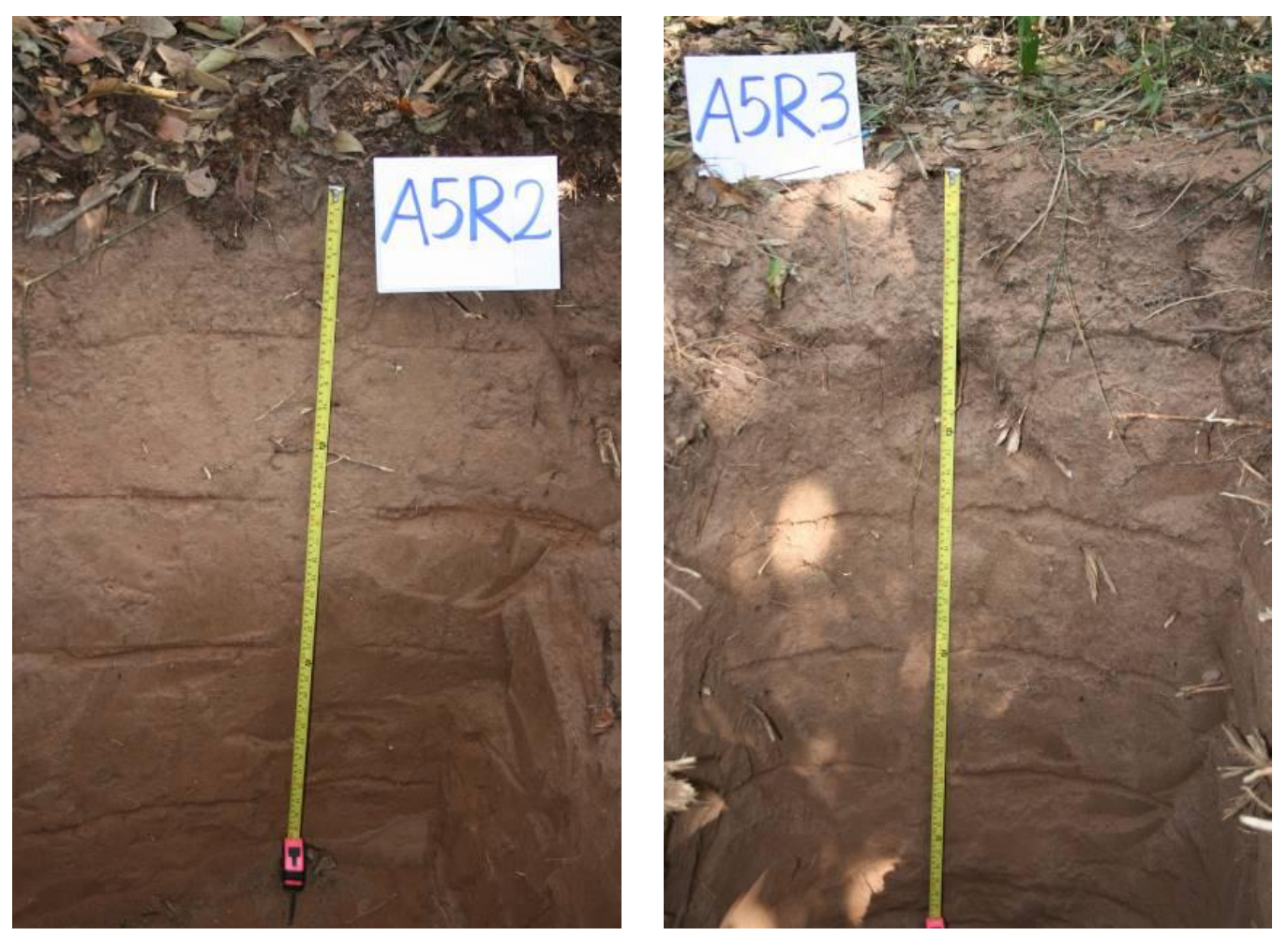

Foto 26: Perfis representativos do solo da Área A5 de mata nativa.

A vegetação, mostrada na Foto 27 (conjunto), é densa, de porte médio a alto. O dossel observado é de $10 \mathrm{~m}$ a $12 \mathrm{~m}$ apresentando algumas porções semiabertas. As árvores, embora de porte alto, possuem troncos não muito grossos. A mata apresenta outros dois estratos verticais, um sub-bosque com espécies arbóreas emergentes e lianas e um estrato herbáceo-arbustivo muito diversificado, mas sem presença de Brachiaria decumbens (capim braquiária), que é uma espécie exótica. A espessura média da camada de serrapilheira é de $8,5 \mathrm{~cm}$ (Foto 28) e as raízes crescem naturalmente até a profundidade máxima observada nas trincheiras (um metro). 

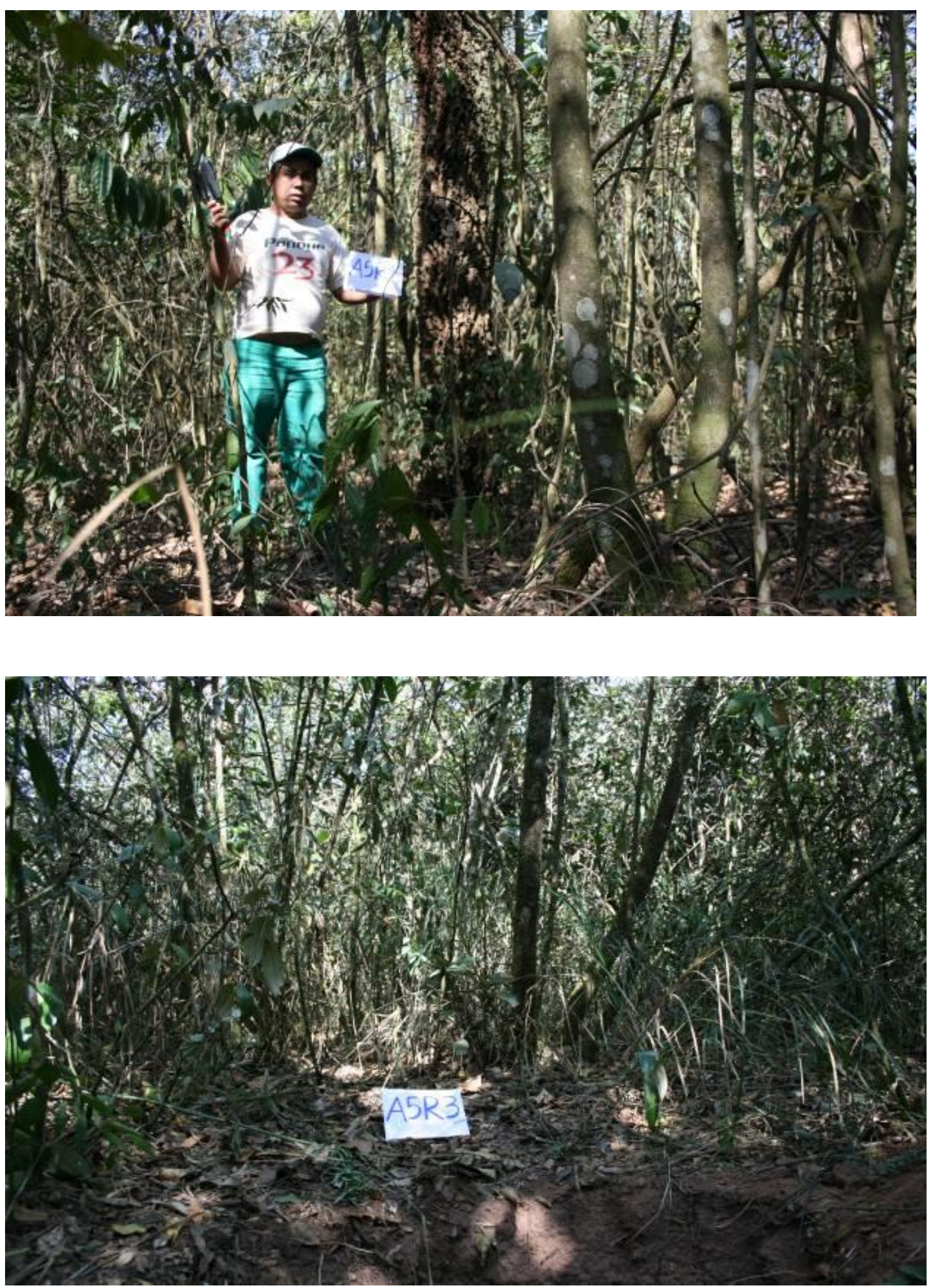

Foto 27: Estado geral da vegetação na Área A5 de mata nativa (conjunto). 


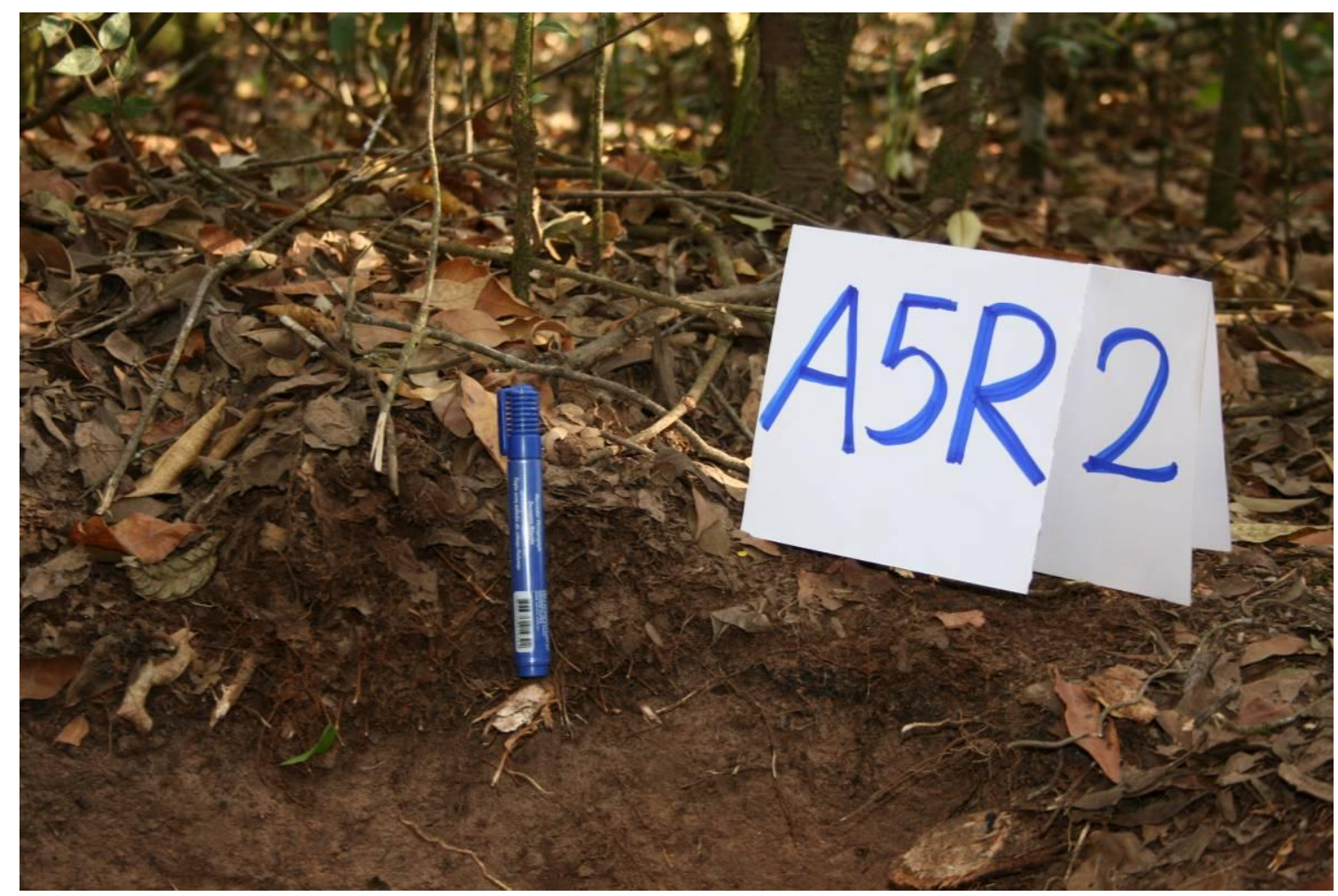

Foto 28: Detalhe da camada de serrapilheira na Área A5 de mata nativa.

\subsection{6 Área A6}

Local onde se encontra outra bacia com disposição mais recente do material de rejeito, aonde também vem ocorrendo disposição do material estéril arenoso em preparo para uma nova revegetação (Fotos 29 e 30). A área foi considerada no estudo como referencial de comparação com as áreas revegetadas.

No momento dos trabalhos de amostragem a área estava sendo preparada e não foi possível a retirada de amostras indeformadas. Klein (2007) comenta que o método do cilindro volumétrico não é indicado para coleta de amostras em solos mobilizados, isto é, imediatamente após a realização de algum tipo de preparo ou movimentação. Nestas condições, além das dificuldades de se obter as amostras, pois o solo não se acondiciona dentro dos cilindros, existe uma quantidade superestimada de espaços vazios o que impossibilita uma coleta representativa. $O$ autor recomenda esperar pelo menos dois a três meses para que ocorra um rearranjo das partículas. 


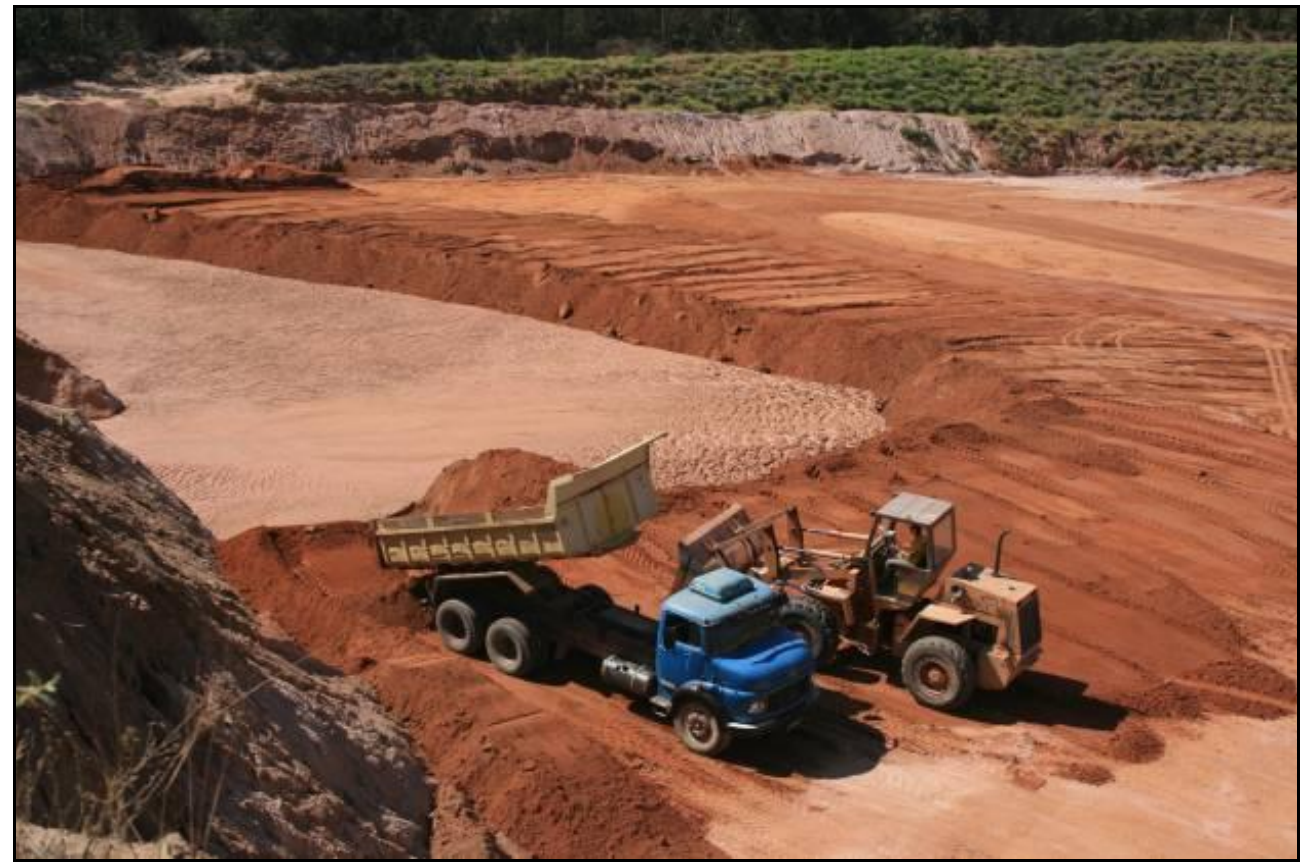

Foto 29: Bacia de rejeito sendo preenchida com material arenoso (estéril).

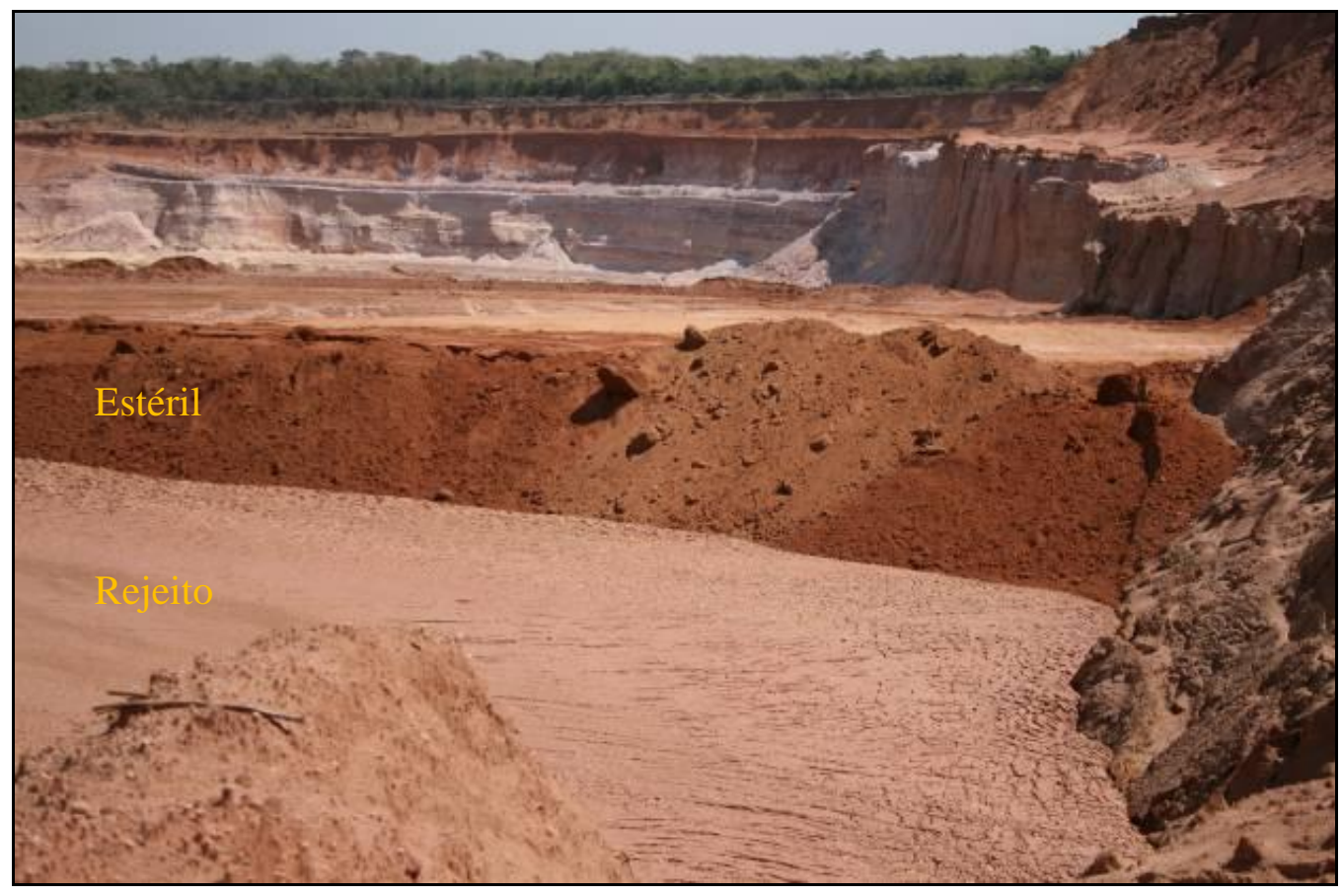

Foto 30: Bacia de rejeito com destaque para o estéril depositado. 
Nesta área foram coletadas apenas amostras deformadas do material estéril recém depositado na bacia para as análises químicas e granulométricas. Também se considerou oportuno obter amostras do próprio rejeito, lama com consistência cremosa e coloração marrom claro, para se compreender melhor estas características (Foto 31). A amostragem do rejeito teve que ser realizada projetandose um balde no interior da bacia, devido à impossibilidade de acesso pessoal, havendo risco iminente de se ficar atolado ou afundar na lama.
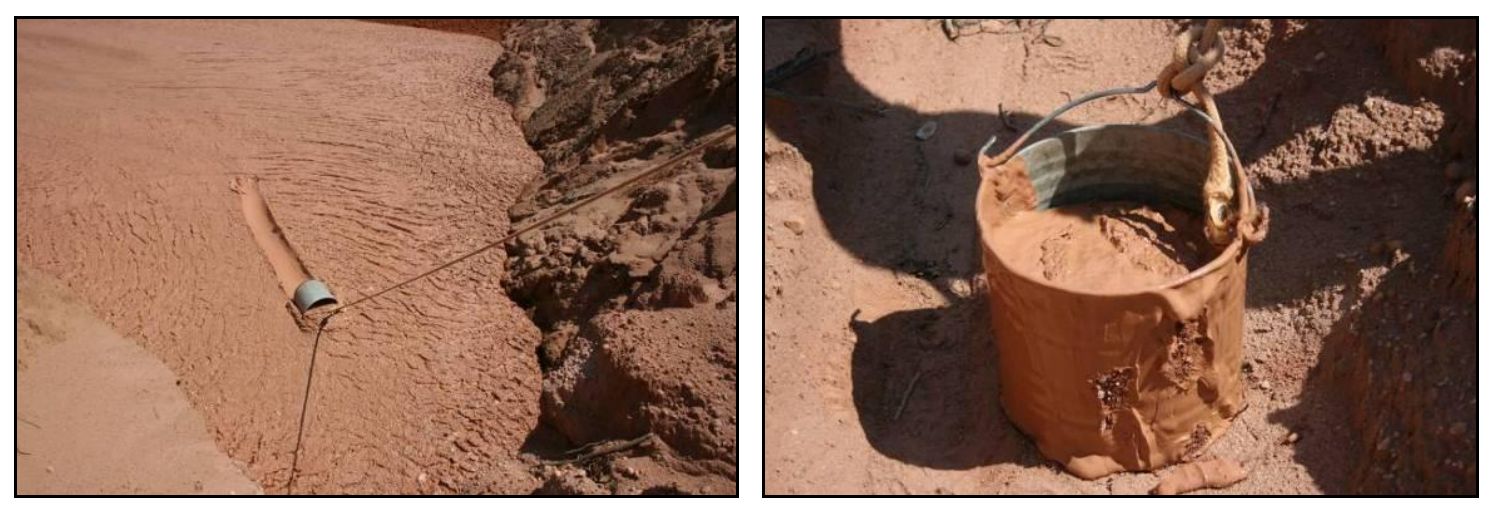

Foto 31: Rejeito com consistência de lama (conjunto).

A Tabela 5 reúne as características mais importantes da vegetação e do substrato, identificados por ocasião da abertura das trincheiras. Embora não tenham sido feitas com muito rigor representativo, as observações como o tamanho da camada de serrapilheira, da profundidade de raízes e do começo da compactação do substrato (esta foi percebida pela dificuldade para abrir as trincheiras e pela diferença de coloração no perfil) são indicadores visuais que auxiliam numa avaliação quanto ao estado geral do ambiente de cada área e, posteriormente orientam uma avaliação mais completa e rigorosa. 
Tabela 5: Características visuais da vegetação e do substrato coletadas nas áreas de estudo.

\begin{tabular}{|c|c|c|c|c|c|c|}
\hline & $\begin{array}{c}\text { A1 } \\
\text { (14 anos) }\end{array}$ & $\begin{array}{c}\text { A2 } \\
\text { (11 anos) }\end{array}$ & $\begin{array}{c}\mathrm{A3} \\
(8 \text { anos })\end{array}$ & $\begin{array}{c}\mathrm{A4} \\
(6 \text { anos })\end{array}$ & $\begin{array}{l}\text { A5 ( Mata } \\
\text { nativa ) }\end{array}$ & $\begin{array}{c}\text { A6 (sem } \\
\text { revegetação) }\end{array}$ \\
\hline $\begin{array}{l}\text { Camada média de } \\
\text { serrapilheira }(\mathrm{cm})\end{array}$ & 5 & 1,5 & 3 & 3,5 & 8,5 & - \\
\hline $\begin{array}{l}\text { Profundidade média } \\
\text { de raízes }(\mathrm{cm})\end{array}$ & 70 & 20 & 40 & 50 & 100 & - \\
\hline $\begin{array}{l}\text { Altura das árvores } \\
\text { (m) }\end{array}$ & 5 a 6 & 1,5 a 4 & 3 a 6 & 3 a 4 & 4 a 8 & \\
\hline $\begin{array}{l}\text { Começo de } \\
\text { compactação da } \\
\text { trincheira }(\mathrm{cm})\end{array}$ & 70 & Na superfície & 40 & 20 & $\begin{array}{c}\text { Sem } \\
\text { compactação }\end{array}$ & $\begin{array}{c}\text { Sem } \\
\text { compactação }\end{array}$ \\
\hline $\begin{array}{l}\text { Características do } \\
\text { sub-bosque }\end{array}$ & $\begin{array}{c}\text { Regenerantes, } \\
\text { pouca } \\
\text { braquiária }\end{array}$ & $\begin{array}{l}\text { Braquiária, } \\
\text { poucas } \\
\text { herbáceas }\end{array}$ & $\begin{array}{l}\text { Braquiária, } \\
\text { herbáceas, } \\
\text { poucos } \\
\text { regenerantes }\end{array}$ & $\begin{array}{c}\text { Regenerantes, } \\
\text { herbáceas, } \\
\text { braquiária }\end{array}$ & $\begin{array}{l}\text { Muitos } \\
\text { regenerantes } \\
\text { herbáceas } \\
\text { lianas }\end{array}$ & $\begin{array}{c}\text { Sem } \\
\text { vegetação }\end{array}$ \\
\hline
\end{tabular}




\section{CAPÍTULO 4}

\section{ANÁLISE E INTERPRETAÇÃO DOS RESULTADOS}

Inicia-se esta análise observando-se o comportamento isolado das variáveis em cada área, considerando a presença de variabilidade entre repetições, e conferindo os resultados numéricos obtidos com valores de referência bibliográficos. No caso das variáveis físico-químicas examina-se o papel da profundidade em que o substrato foi colhido, pois é esperado que em camadas mais profundas as características químicas não têm relação com a vegetação. Também se analisa o comportamento de cada variável em relação às outras áreas observando-se as tendências de acordo com a idade de revegetação. Comparações entre as áreas revegetadas e a área sem revegetação ou a mata nativa são essenciais para se avaliar a evolução esperada na melhoria na recuperação. Adicionalmente, verifica-se o grau de correlação entre as variáveis, assim como a relação do desenvolvimento da vegetação com as características físico-químicas do substrato. Neste caso o intuito é ponderar sobre quais variáveis podem ser classificadas como indicadoras da recuperação do substrato.

As análises descritivas e comparações visuais são possíveis mediante o cálculo de medidas resumo, apresentadas no Apêndice $B$, contendo a média, a mediana, o mínimo, o máximo, o desvio padrão (DP) e o coeficiente de variação (CV) para todas as variáveis e a construção de tabelas, diagramas e gráficos de perfis médios (Apêndice $\mathrm{C}$ ). Em muitos casos, para as relações entre variáveis ou entre áreas, fez-se necessário a análise estatística inferencial com a utilização de modelos de regressão linear, construção de intervalos de confiança e análises de covariância multivariada proporcionados por Tanaka et al (2009). Estes pesquisadores elaboraram um relatório de análise estatística completa e detalhada do presente trabalho. Os resultados das análises do substrato e das observações na vegetação foram encaminhados ao CEA-USP (Centro de Estatística Aplicada da USP) que presta serviços de consultoria estatística, gerando a análise referida. 


\subsection{Comentários sobre os resultados dos parâmetros físicos}

\subsubsection{Granulometria e densidade de partículas (Dp)}

O traçado da curva granulométrica fornece resultados sobre o tamanho dos grãos e indica o conteúdo, em porcentagem passante de areia, silte e argila. Como exemplo, as curvas das amostras da área A1 (Figura 5) apresentam porcentagens mínimas de argila e silte, sendo o conteúdo de areia muito alto. Esta tendência é similar em todas as amostras, pelo que se infere que as porcentagens citadas de partículas se mantêm constantes em todas as profundidades observadas.

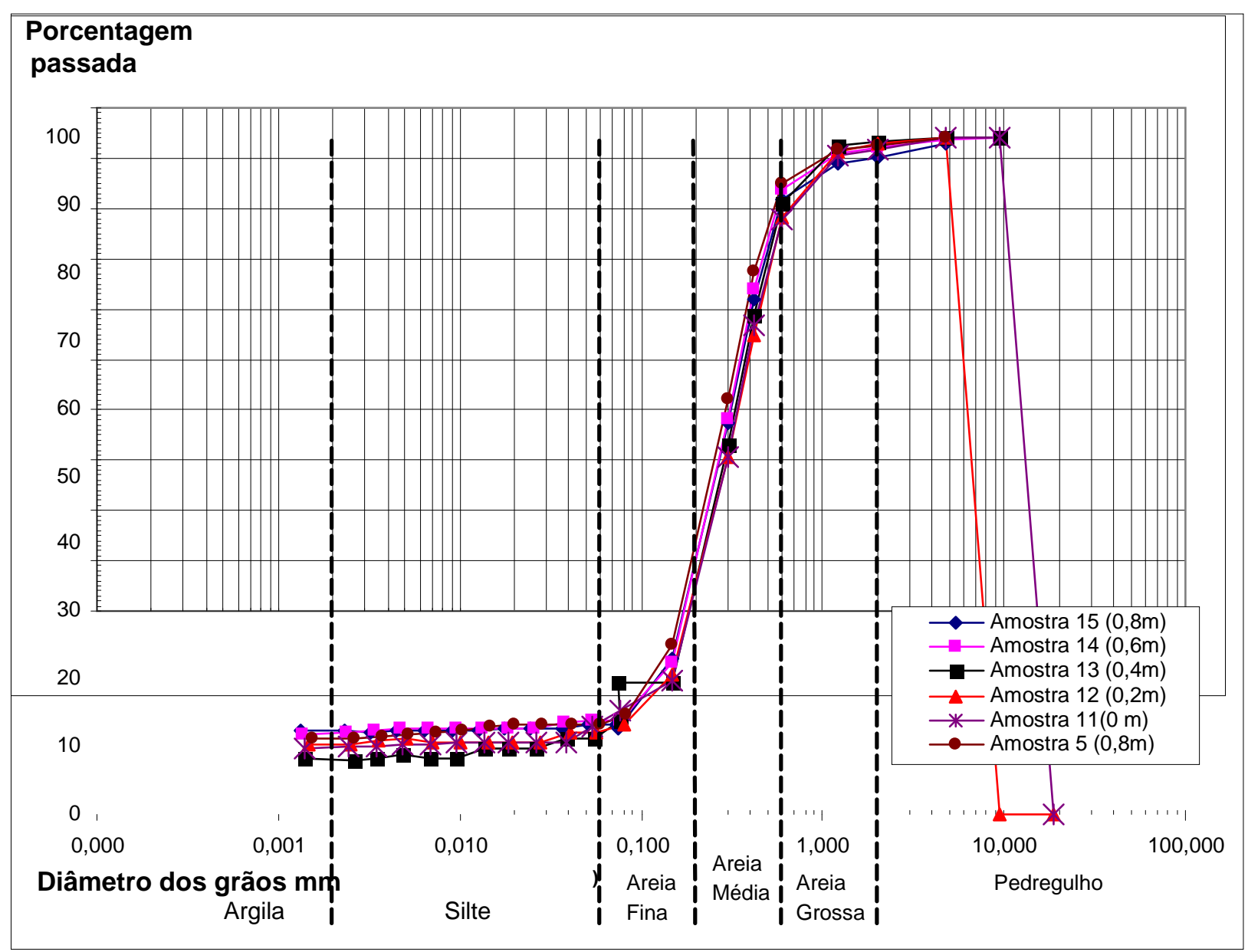

Figura 5: Curvas granulométricas das frações areia, silte e argila, em diferentes profundidades da área A1. 
A Tabela 6 apresenta os resultados médios de granulometria e densidade de partículas considerando as camadas observadas em todas as áreas de estudo. A granulometria na superfície apresenta porcentagens de areia ligeiramente mais altas que nas camadas mais profundas, enquanto a porcentagem de argila apresenta leve tendência a aumentar com a profundidade. Contudo, a classe textural do material em todas as camadas é predominantemente arenosa segundo a determinação pelo triângulo textural (BRADY; WEIL, 2007).

O resultado granulométrico do rejeito, que contém 4,5\% de argila, 88,6\% de silte e $7 \%$ de areia, demonstra que o material fino é preferencialmente silte. Este material se caracteriza por reter mais água e promover uma taxa de drenagem menor. Tal fato determina a dificuldade que as minerações encontram para desaguar este tipo de rejeito.

Tabela 6: Granulometria e Dp média por camadas observadas.

\begin{tabular}{|ccccc|}
\hline $\begin{array}{c}\text { Camada } \\
(\mathrm{cm})\end{array}$ & Argila \% & Silte \% & Areia \% & Dp \\
\hline $0-20$ & 5,8 & 3,4 & 90,7 & 2,6 \\
$20-40$ & 6,1 & 2,9 & 90,7 & 2,5 \\
$40-60$ & 6,7 & 3,2 & 90,1 & 2,6 \\
$60-80$ & 7,1 & 3,6 & 89,3 & 2,6 \\
$80-100$ & 8,2 & 2,3 & 89,5 & 2,6 \\
Rejeito & 4,5 & 88,6 & 7,0 & 2,7 \\
\hline
\end{tabular}

Comparando-se a granulometria das áreas estudadas, na Tabela 7 observase que não há diferenças significativas para as amostras coletadas, sendo que em todos os casos a classe textural também é arenosa, seguindo a mesma tendência já observada na Figura 4 para a área A1. Quanto à densidade de partículas (Dp), segundo Brady e Weil (2007), a Dp na maioria dos solos varia de 2,6 a 2,75 Mg.m ${ }^{-3}$. Este valor decorre da predominância de minerais como quartzo, feldspato, mica e silicatos, cuja densidade situa-se dentro desta faixa. Os valores de Dp obtidos

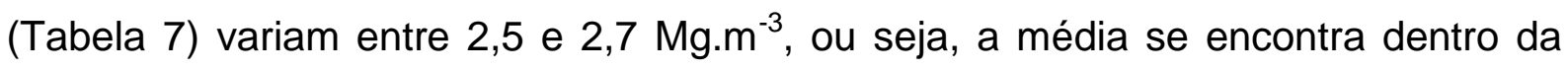
faixa citada pela bibliografia. 
Tanto a textura como a Dp não constituem indicadores sensíveis de possíveis mudanças nas situações estudadas, mas são parâmetros importantes para a caracterização do substrato e para o entendimento do seu comportamento como meio de crescimento da vegetação. Sua determinação é útil, principalmente, em situações onde não se conheça a origem do material utilizado como substrato. As granulometrias do total de amostras analisadas podem ser observadas no Anexo D.

Tabela 7: Granulometria e Dp média $\left({\left.\mathrm{Mg} . \mathrm{m}^{-3}\right)}^{-3}\right.$ por área de estudo.

\begin{tabular}{|lcccc|}
\hline \multicolumn{1}{|c}{ Área } & Argila \% & Silte $\%$ & Areia \% & Dp $\left({\left.\mathrm{Mg} . \mathrm{cm}^{-3}\right)}^{-3}\right.$ \\
\hline A1 (14 anos) & 9,2 & 1,7 & 89,1 & 2,5 \\
A2 (11 anos) & 4,6 & 3,2 & 92,2 & 2,7 \\
A3 (8 anos) & 6,1 & 3,8 & 90,1 & 2,6 \\
A4 (6 anos) & 6,6 & 3,3 & 90,1 & 2,6 \\
A5 (Mata & & & & \\
nativa) & 7,0 & 3,9 & 89,1 & 2,6 \\
A6 (Sem rev.) & 3,7 & 4,3 & 92,0 & 2,6 \\
& & & & \\
\hline
\end{tabular}

\subsubsection{Densidade de solo (Ds)}

A Ds é definida como a massa por unidade de volume de solo seco. No substrato das áreas revegetadas constatam-se valores altos de Ds, com exceção da mata nativa que apresenta valores menores (Tabela 8). Segundo Brady e Weil (2007), em solos arenosos o conteúdo de matéria orgânica geralmente é baixo, as partículas sólidas estão menos predispostas a formarem agregados e a Ds é normalmente mais alta do que em solos de textura fina. O conteúdo de matéria orgânica é fundamental para que as partículas se organizem em unidades estruturais porosas (agregados). Além do espaço poroso entre os agregados, existe o espaço ocupado por poros internos aos agregados. Esta condição garante que a Ds diminua, sendo este o caso do solo da mata nativa que, na granulometria, não difere dos substratos das áreas revegetadas, porém apresenta os menores valores 
de Ds na camada superficial, revelando seu maior conteúdo de matéria orgânica pela cor de solo mais escura, a maior presença de raízes e os resultados da análise de teor apresentados posteriormente. A partir dos $20 \mathrm{~cm}$, a Ds deste substrato se mantém estável ao longo do perfil devido à presença abundante de raízes até $1 \mathrm{~m}$ de profundidade. A partir dos $20 \mathrm{~cm}$, a Área A1 (14 anos) apresenta resultados próximos aos da mata nativa, mantendo os valores de Ds uniformes ao longo do perfil. Esta área tem presença de raízes até o limite de $70 \mathrm{~cm}$.

A Tabela 8 apresenta os resultados médios obtidos para a Ds nas diferentes áreas e profundidades. Conforme já comentado, não foi possível a coleta de amostras na área A6 (sem revegetação), pois na época de amostragem o local ainda estava fase de preparação. Klein (2007) aconselha não amostrar solos recentemente mobilizados, pois a coleta de amostras indeformadas não será representativa devido à existência de uma quantidade superestimada de espaços vazios. Como o estéril da mineração é solto e arenoso e provém de uma área recentemente desmatada, em princípio pode-se deduzir que a sua Ds deve apresentar valores semelhantes ou ainda menores do que os encontrados na mata nativa. Posteriormente, fatores como tráfego sistemático de máquinas nas operações de transporte do estéril, a adição de solo superficial, a preparação para a semeadura e a abertura de covas no plantio ocasionam a diminuição do volume por compressão, com expulsão do ar intersticial do material e o rearranjo das partículas constituintes. Brady e Weil (2007) acrescentam que o tráfego é particularmente prejudicial em condições de alta umidade, quando a movimentação das cargas pesadas provoca compactação severa e profunda. Estes autores fornecem valores de ao redor de 1,25 Mg.m ${ }^{-3}$ para solos arenosos não compactados e até 1,99 Mg.m- ${ }^{3}$ para os compactados. Sobre o assunto, Machado (2003) afirma que a Ds é a medida quantitativa mais direta da compactação. As observações de campo confirmam os resultados apresentados, pois nas áreas revegetadas (principalmente na A2) houve dificuldade na abertura das trincheiras. 
Tabela 8: Resultados médios de Ds (Mg. ${ }^{-3}$ ) nas áreas de estudo.

\begin{tabular}{|c|c|c|c|c|c|}
\hline $\begin{array}{l}\text { Profundidade } \\
\text { (cm) }\end{array}$ & & & Áreas & & \\
\hline & $\begin{array}{c}\text { A4 } \\
\text { (6 anos) }\end{array}$ & $\begin{array}{c}\text { A3 } \\
\text { (8 anos) }\end{array}$ & $\begin{array}{c}A 2 \\
\text { (11 anos) }\end{array}$ & $\begin{array}{c}\text { A1 } \\
\text { (14 anos) }\end{array}$ & $\begin{array}{c}\text { A5 (Mata } \\
\text { nativa) }\end{array}$ \\
\hline $0-20$ & 1,47 & 1,42 & 1,55 & 1,42 & 1,14 \\
\hline $20-40$ & 1,7 & 1,43 & 1,62 & 1,49 & 1,44 \\
\hline $40-60$ & 1,67 & 1,56 & 1,63 & 1,5 & 1,44 \\
\hline $60-80$ & 1,71 & 1,58 & 1,75 & 1,45 & 1,44 \\
\hline $80-100$ & 1,71 & 1,75 & 1,79 & 1,48 & 1,44 \\
\hline
\end{tabular}

$\mathrm{Na}$ Tabela 8 verifica-se que, nas áreas revegetadas, a camada superficial apresenta valores menores de Ds e a tendência é de aumentarem com a profundidade.

Com o propósito de verificar os efeitos da área e da profundidade para cada variável, Tanaka et al. (2009) aplicaram um modelo de análise de variância denominado modelo misto para medidas repetidas, que envolve análise de resíduos e de normalidade. O passo final desta seqüência de análise verifica as diferenças entre os valores médios de cada variável nas comparações simultâneas entre áreas e entre profundidades. O método utiliza intervalos de confiança simultâneos de Bonferroni com um nível de $95 \%$ de confiança, o que significa que em $95 \%$ dos casos o resultado é confiável. Esta ferramenta estatística verifica se um local investigado tem, em média, a mesma quantidade de uma determinada substância ou a mesma condição de uma determinada variável observada, ao se comparar com outro local.

Na Tabela 9 (apresentada como exemplo) compara-se a Ds nas diferentes profundidades, duas a duas. De acordo com a definição do intervalo de confiança, se o zero estiver dentro do intervalo, então se afirma que a diferença entre as médias é zero. Verifica-se que o intervalo de confiança para a diferença média entre a camada de $0-20 \mathrm{~cm}$ e a camada $20-40 \mathrm{~cm}$ não contém o zero, ou seja, estas camadas não apresentam, em média, os mesmos valores de Ds sendo então significativamente diferentes. Situação semelhante se apresenta nas comparações entre a camada superficial com as demais. Comparações deste tipo são úteis e 
elucidativas para se analisar o comportamento das variáveis em estudo, do ponto de vista estatístico.

\section{Tabela 9: Intervalos de confiança de Bonferroni para a variável Ds nas diferentes profundidades.}

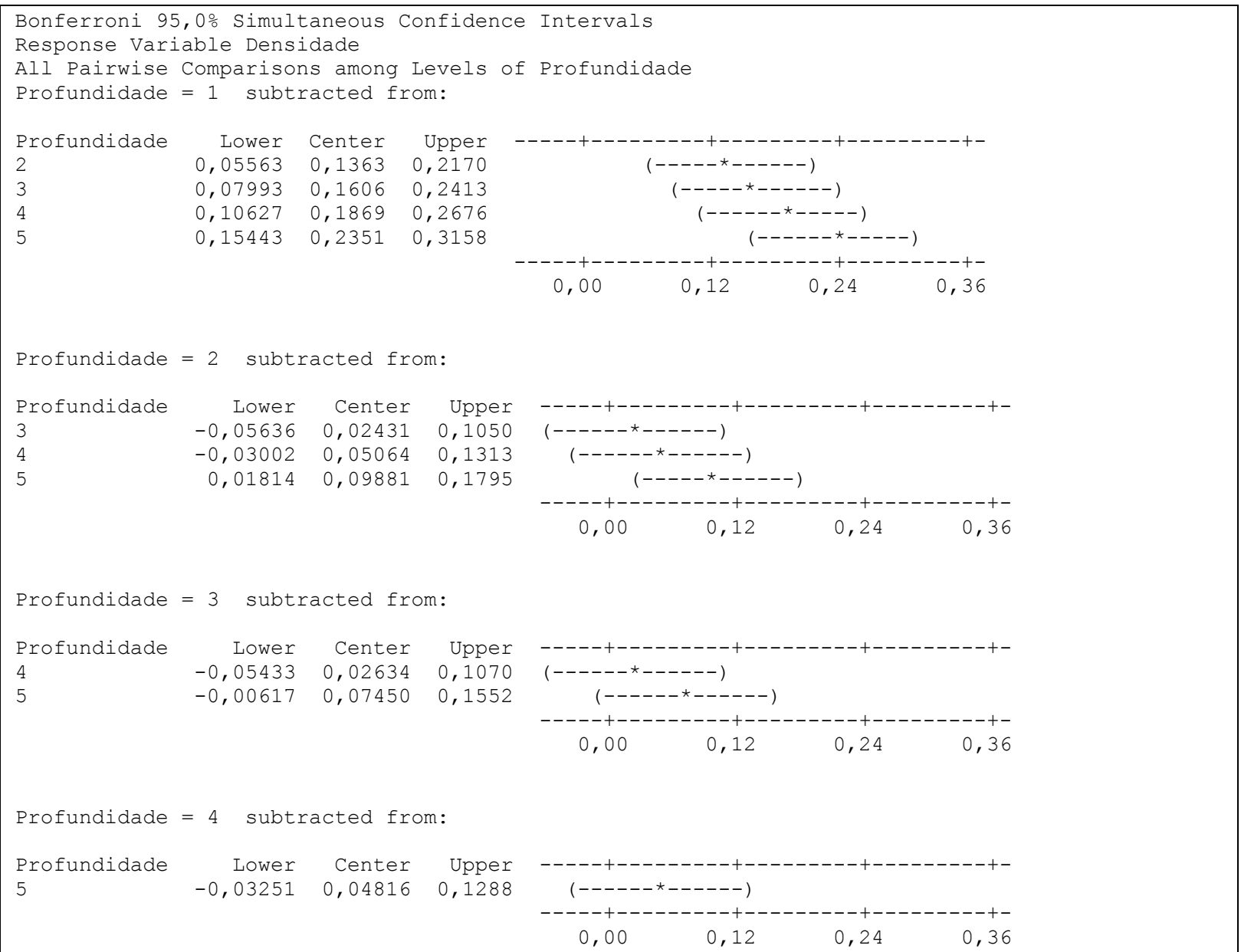

Fonte: Tanaka et al. (2009)

Resultados semelhantes, com a densidade do solo aumentando com a profundidade, foram encontrados por Alves et al. (2007), quando avaliaram a recuperação de uma área degradada de onde foi retirada uma camada de 8,6 $\mathrm{m}$ para a terraplenagem na construção das fundações de uma usina hidroelétrica.

Para efeito de comparação entre áreas, é mais relevante a observação da Ds na camada superficial, por ser a mais atuante no desenvolvimento das raízes. $\mathrm{Na}$ cronoseqüência da Tabela 8 não se observa uma tendência linear com diminuição 
da Ds em relação à idade, sendo a A2 (11 anos) a que apresenta os valores mais altos.

A Tabela 10 compara os resultados de Ds entre as áreas, duas a duas. Os intervalos de confiança de Bonferroni evidenciam diferenças significativas das áreas revegetadas em comparação à mata nativa, significando que nenhuma área revegetada tem equivalência com a Ds da mata, tida como valor de referência. Os intervalos só apontam equivalência entre as Ds das áreas A2 e A4.

Tabela 10: Intervalos de confiança de Bonferroni para a variável Ds nas diferentes áreas.

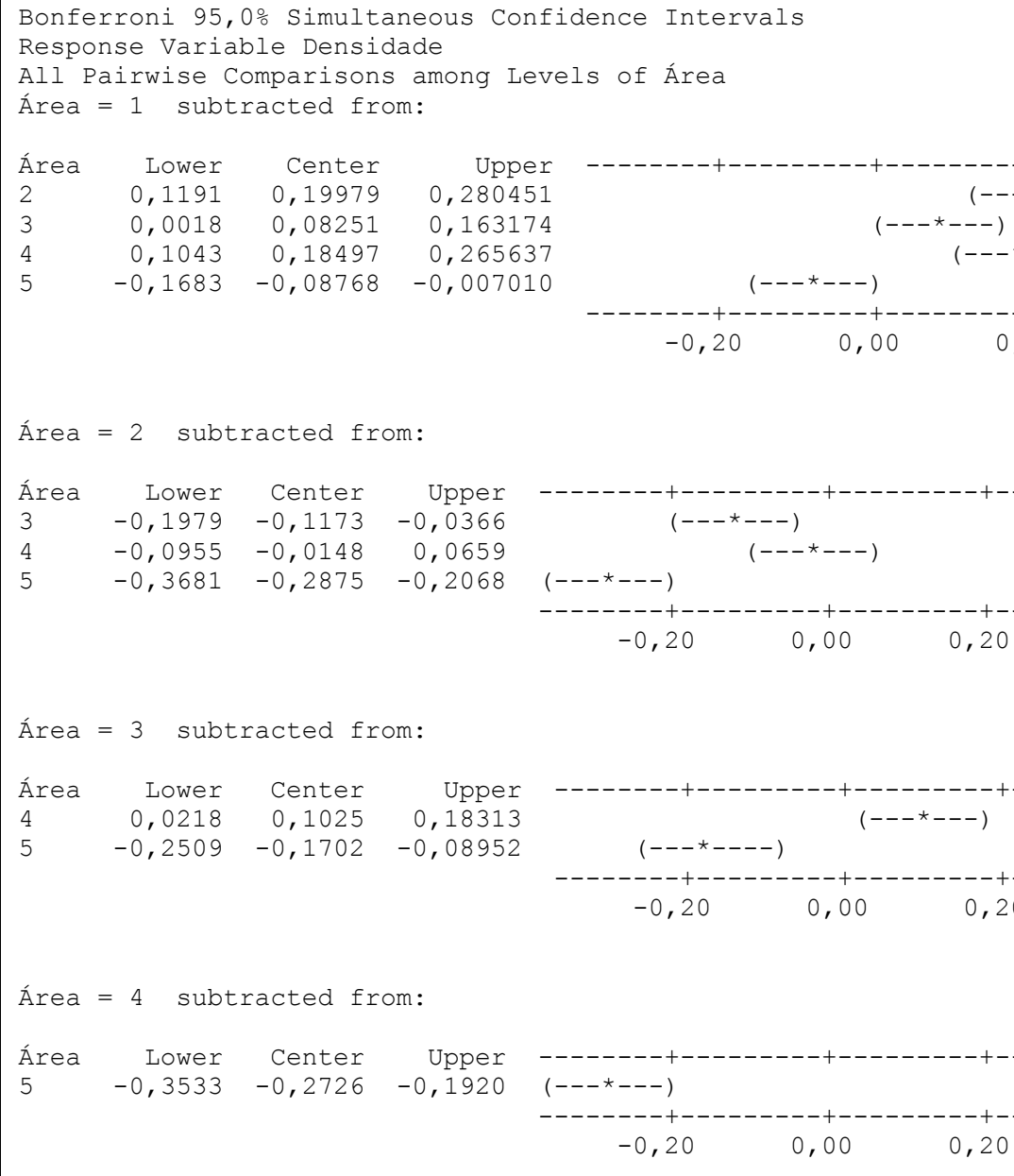

Área $=3$ subtracted from:

Área $=4$ subtracted from:

Área Lower Center Upper

$5-0,3533-0,2726-0,1920 \quad\left(---{ }_{---}\right)$

$$
-0,20 \quad 0,00 \quad 0,20
$$

Fonte: Tanaka et al. (2009)

Primavessi (1981) comenta que valores de Ds altos geram deterioração das condições gerais do meio para o desenvolvimento das plantas ocasionando menor difusão de oxigênio, menor disponibilidade de água, baixo desenvolvimento radicular 
e menos absorção de nutrientes. Brady e Weil (2007) comentam que solos compactados secos podem restringir completamente a penetração radicular, e permiti-la em algum grau quando úmidos. A estação de seca em Descalvado origina um balanço hídrico negativo entre os meses de abril a setembro (período em que se realizaram os levantamentos de campo), indicando deficiência de água em todas as áreas, o qual também deve estar refletido nos valores de Ds encontrados e seus efeitos nas plantas. Outro aspecto a ser considerado é o fato da área A2 encontrarse numa cota mais alta que às demais áreas revegetadas, ocasionando a drenagem das águas de chuva principalmente para a área A3 (8 anos) cuja cota é mais baixa (diferença de $2 \mathrm{~m}$ ), fato que potencializa os efeitos do balanço hídrico negativo na área $\mathrm{A} 2$ e favorece a $\mathrm{A} 3$.

A densidade do solo é uma das propriedades físicas citadas por Letey (1985) indiretamente relacionadas com o desenvolvimento das plantas, assim como a granulometria, a agregação e a porosidade. $O$ autor manifesta que os efeitos destes fatores sobre o crescimento vegetal ocorrem por suas influências sobre a retenção de água, a aeração, a temperatura e a resistência do solo à penetração. Solos com alta densidade têm influência negativa na germinação, na emergência de plântulas, no crescimento radicular e praticamente em todas as fases de crescimento das plantas. Primavessi (1985) afirma que o enraizamento abundante pode descompactar o solo a longo prazo, sem o uso de máquinas. A autora utiliza o termo "subsoladores naturais" para plantas com raízes profundas e que penetram mesmo em locais muito compactados.

Os resultados de Ds obtidos para as áreas revegetadas da bacia significam valores elevados de compactação que aumentam com a profundidade e na época de seca.

\subsubsection{Porosidade total}

Utilizando-se os resultados médios de densidade de partícula, realizou-se o cálculo para esta variável mediante a expressão (3).

Como os resultados foram obtidos a partir de Ds, a dependência entre esta variável e a porosidade é forte e confirmada pela correlação linear negativa alta (0,98) encontrada por Tanaka et al. (2009) no Anexo A. As tendências encontradas 
para a variável Ds, também se aplicam a esta variável, embora com sentido oposto. Assim, a porosidade é significativamente mais alta na superfície e com tendência a diminuir com a profundidade, como se observa na Tabela 11. Os valores indicam que a mata nativa apresenta porosidade maior na camada superficial. Apesar da pequena diminuição após dos $20 \mathrm{~cm}$, os valores se mantêm homogêneos ao longo do perfil. Embora a classe textural seja arenosa em todas as áreas de estudo, a maior porosidade na mata reflete uma maior agregação do material nesta área, provavelmente também relacionado com a maior atividade microbiana e a presença de raízes observada nos perfis.

Comparando-se as áreas, a evolução da porosidade ao longo do tempo de estudo não demonstra uma tendência clara: aumenta até os 8 anos, mas aos 11 anos diminui de forma considerável. Na camada superficial, a área A2 (11 anos) apresenta o valor mais baixo de porosidade e coincide com os valores de Ds mais altos conferidos para esta mesma área. Uma confirmação deste fato é o resultado dos intervalos de confiança de Bonferroni (TANAKA et al. 2009) que, neste caso, apontam equivalência de porosidade entre as áreas A2 e A4 e entre A1 e A3. Nenhuma área revegetada atingiu equivalência com a mata nativa.

Tabela 11: Porosidade total média (\%) nas áreas de estudo.

\begin{tabular}{|c|ccccc|}
\hline $\begin{array}{c}\text { Profundidade } \\
\text { (cm) }\end{array}$ & \multicolumn{5}{|c|}{ Áreas } \\
\cline { 1 - 5 } & A4 & A3 & A2 & A1 & A5 \\
& (6 anos) & (8 anos) & (11 anos) & (14 anos) & (Mata nativa) \\
\cline { 1 - 5 } $0-20$ & 44,08 & 46,01 & 41,15 & 44,18 & 56,91 \\
\cline { 1 - 1 } $20-40$ & 35,55 & 45,64 & 38,47 & 41,51 & 45,20 \\
\cline { 1 - 1 } $40-60$ & 36,75 & 40,62 & 38,04 & 41,03 & 45,29 \\
\cline { 1 - 1 } $60-80$ & 34,96 & 40,00 & 33,68 & 42,89 & 45,28 \\
\cline { 1 - 1 } $80-100$ & 34,95 & 33,46 & 32,14 & 41,75 & 45,34 \\
\hline
\end{tabular}

Nos gráficos da Figura 5 observa-se o comportamento da Ds e da porosidade na camada superficial $(0-20 \mathrm{~cm})$ e na mais profunda $(80-100 \mathrm{~cm})$. Destaca-se a comparação do desempenho das variáveis nestas duas camadas. $\mathrm{Na}$ camada superficial a Ds sempre é menor que nas camadas mais profundas, enquanto que 
com a porosidade acontece o oposto, a camada superficial apresenta porosidade maior. Portanto, é possível perceber que os resultados de densidade de solo e porosidade são opostos, a Ds aumenta com a profundidade, enquanto a porosidade diminui.
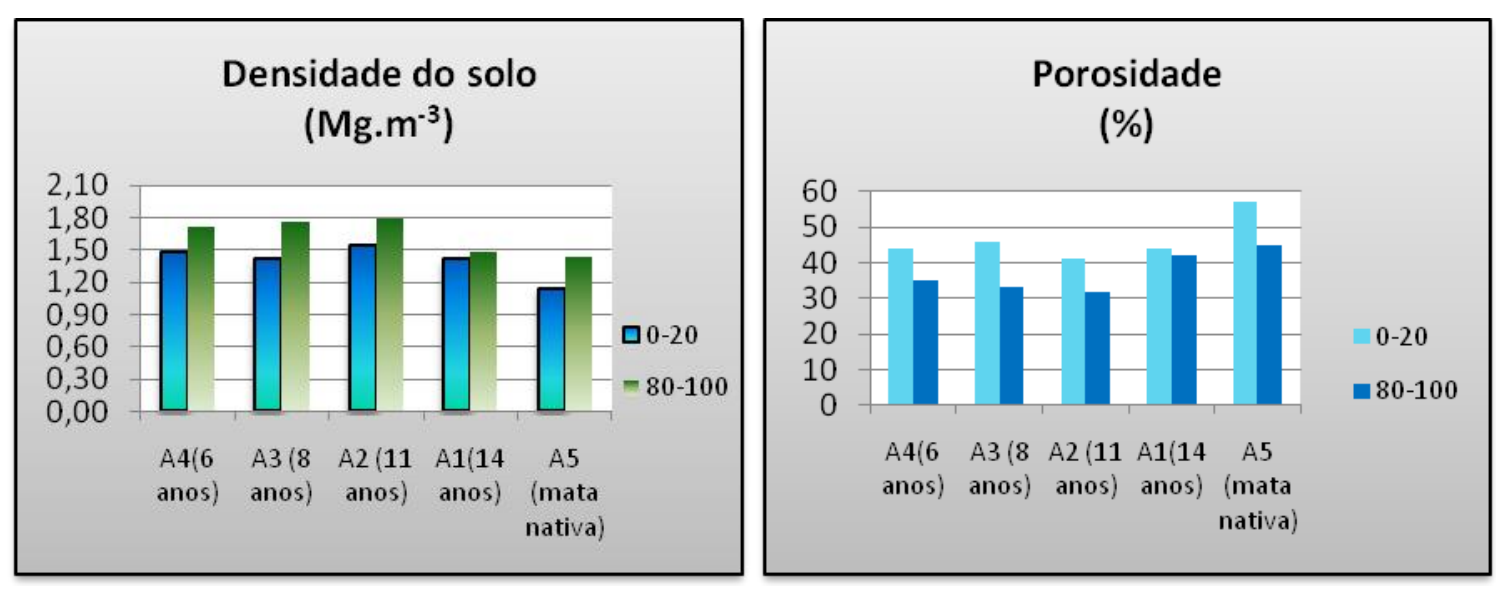

Figura 6: Resultados médios de densidade de solo e porosidade na camada superficial $(0-20 \mathrm{~cm})$ e na mais profunda $(80-100 \mathrm{~cm})$.

As tabelas resumo apresentadas no Apêndice B, tanto de Ds como de porosidade, mostram que há pouca variabilidade nos dados obtidos em cada profundidade (ver o desvio padrão, DP e o coeficiente de variabilidade, CV), o que significa que nos locais em que as amostras foram coletadas (trincheiras) predomina a homogeneidade destas variáveis, confirmando a tese de representatividade de ambas as variáveis.

\subsection{Resultados e comentários dos parâmetros químicos}

Assim como ocorreu com a tendência das variáveis físicas, nas variáveis químicas observadas, os valores na camada superficial têm comportamento diferenciado em relação às demais camadas e a mata nativa apresenta menor variabilidade nos valores obtidos nas diferentes profundidades. Algumas exceções serão comentadas oportunamente. Novamente, nas tabelas-resumo do Apêndice B, 
os valores obtidos na superfície $(0-20 \mathrm{~cm})$, não diferem muito nas três trincheiras indicando aparente homogeneidade nos dados.

\subsection{1 $\mathrm{pH}$}

Os valores medidos de $\mathrm{pH}$ (Tabela 12) variaram de 3,3 a 5,9, ou seja, significam substratos ácidos em todas as situações, mesmo no solo da mata nativa. Os valores concidem com os estudos de Ruggiero \& Pivello (2005) para áreas de Cerradão na Gleba Cerrado Pé-de-Gigante no Parque Estadual de Vassununga, SP. Estes autores apontam que a acidez é freqüente nos solos sob Cerrado, com pH entre 4,8 e 5,2. Os valores são baixos, característicos de solos desenvolvidos a partir de arenitos ou sedimentos areno-quartzosos (CORRÊA, 2006).

Troeh e Thompson (2007) confirmam que a condição ácida do solo faz com que todos os cátions básicos presentes no solo declinem ou se tornem não disponíveis para a sua absorção pelas raízes das plantas. O solo ácido ocorre geralmente em locais de climas úmidos, onde os processos de lixiviação são mais intensos e a remoção de substâncias básicas do solo é mais ativa. A lixiviação refere-se à remoção de materiais que se dissolvem na água de chuva, à medida que esta flui pelo solo.

Quando há necessidade de correção da acidez de um solo ou substrato, realiza-se a calagem, isto é a adição dos corretivos da acidez. Os corretivos mais utilizados são as rochas calcárias moídas, chamados simplesmente "calcários". Além de corrigir a acidez, a calagem supre o solo de cálcio e magnésio, promove o aumento da capacidade de troca catiônica e também a disponibilidade de fósforo, nitrogênio, enxofre e molibdênio. A mineralização da matéria orgânica é favorecida, o volume explorado pelas raízes aumenta e a fixação simbiótica do nitrogênio é acrescda (IAC, 1997).

A área de mata nativa, onde não houve aplicação de calcário, e a área $A 1$, de revegetação mais antiga, apresentam os valores mais baixos de $\mathrm{pH}$. Devido à densa vegetação observada na mata nativa, certamente as espécies estão adaptadas aos valores de $\mathrm{pH}$ baixos, conforme é comentado por Primavessi (1981) para solos de Cerrado. 
$\mathrm{Na}$ mata nativa observa-se uma leve tendência no incremento do $\mathrm{pH}$ relativo aos níveis mais profundos, coincidindo novamente com Ruggiero e Pivello (2005) e Silva Jr. et al. (1987), que constataram aumento de $\mathrm{pH}$ com a profundidade; normalmente a superfície é mais ácida por conta do maior conteúdo de matéria orgânica. Nas áreas revegetadas, o pH da camada superficial é ligeiramente mais alto, provavelmente devido à aplicação de calcário realizada no preparo do substrato antes do plantio de mudas. Os valores de $\mathrm{pH}$ mais altos nas camadas mais profundas da área $\mathrm{A} 2$ refletem a existência de algum material estéril atípico usado como preenchimento da bacia que foi amostrado nas trincheiras.

Tabela 12: Valores médios do pH nas áreas de estudo.

\begin{tabular}{|c|c|c|c|c|c|c|}
\hline $\begin{array}{l}\text { Profundidade } \\
\text { (cm) }\end{array}$ & & & Áreas & & & \\
\hline & $\begin{array}{c}\text { A6 } \\
\text { (0 anos) }\end{array}$ & $\begin{array}{c}\text { A4 } \\
\text { (6 anos) }\end{array}$ & $\begin{array}{c}\text { A3 } \\
\text { (8 anos) }\end{array}$ & $\begin{array}{c}\text { A2 } \\
\text { (11 anos) }\end{array}$ & $\begin{array}{c}\text { A1 } \\
\text { (14 anos) }\end{array}$ & $\begin{array}{c}\text { A5 (Mata } \\
\text { nativa) }\end{array}$ \\
\hline $0-20$ & 4 & 4,6 & 3,9 & 4,4 & 3,8 & 3,6 \\
\hline $20-40$ & 4,1 & 4 & 3,6 & 3,9 & 3,5 & 3,8 \\
\hline $40-60$ & 4,1 & 4 & 3,7 & 4 & 3,5 & 3,9 \\
\hline $60-80$ & 4,1 & 4 & 3,9 & 4,9 & 3,5 & 3,8 \\
\hline $80-100$ & 4,2 & 4,3 & 4 & 5,5 & 3,5 & 3,9 \\
\hline
\end{tabular}

\subsubsection{Teor de matéria orgânica ( MO )}

Souza e Lobato (2002), apud Corrêa (2006), assinalam valores de MO, em textura arenosa, entre 8 a $15 \mathrm{~g} \cdot \mathrm{dm}^{-3}$ como baixo e alto respectivamente. Em geral, Outros autores consideram teores entre 10 e $50 \mathrm{~g} \cdot \mathrm{dm}^{-3}$ como valores extremos. Em qualquer dos casos, a Tabela 13 destaca que o teor de MO no primeiro nível (0 - 20 $\mathrm{cm}$ ) é alto, tanto na mata nativa como nas revegetações estudadas, o que demonstra uma melhoria no conteúdo de MO no decorrer do tempo, por conta da própria implantação de vegetação. Para corroborar com esta afirmação, pode-se observar os resultados na área $A 6$ (sem revegetação) com conteúdos menores desta variável, principalmente na camada superficial.

Quanto mais antiga a revegetação, a tendência esperada é de maior acúmulo de $\mathrm{MO}$ nas camadas superiores. Mas a área $\mathrm{A} 2$, com 11 anos de revegetação, 
apresenta teores menores de $\mathrm{MO}$ do que as áreas com 6 e 8 anos de revegetação. As áreas A1 (14 anos), A3 (8 anos) e A4 apresentam valores equivalentes aos da mata nativa, segundo os intervalos de confiança de Bonferroni construidos para esta variável por Tanaka et al. (2009).

É destacável o comportamento da MO na cronosseqüência da Tabela 13, onde a camada superficial das revegetações com 6, 8 e 14 anos apresentam conteúdos semelhantes ou até melhores de MO. No entanto, nestas áreas observase o crescimento vigoroso de capim braquiária, gramínea invasora típica de locais ácidos, que se caracteriza por proporcionar matéria orgânica, embora não permita que outras espécies regenerantes se estabeleçam no local. Certamente, a braquiária também está contribuindo nos resultados para teores de MO mais elevados.

Troeh e Thompsom (2007) explicam porque, em solos ocupados por florestas, os conteúdos de MO mais importantes são relativos à camada superficial. Nesses casos, a principal fonte de MO é oriunda da queda de folhas e galhos, que acabam formando uma camada grossa que cobre a superfície do solo. As raízes têm contribuição limitada, já que permanecem vivas por muitos anos. Nas revegetações em estudo, a contribuição de MO é compartilhada pela presença marcante de herbáceas gramíneas.

O teor muito baixo de $\mathrm{MO}$ na área $\mathrm{A6}$ (sem revegetação) tem relação com a camada de estéril adicionada que provém originalmente de camadas sub-superficiais sem conteúdo de solo orgânico ou superficial.

Tabela 13: Teores médios de matéria orgânica $\left(\mathrm{g}_{\mathrm{dm}} \mathrm{dm}^{-3}\right)$ nas áreas de estudo.

\begin{tabular}{|c|c|c|c|c|c|c|}
\hline $\begin{array}{l}\text { Profundidade } \\
\text { (cm) }\end{array}$ & \multicolumn{5}{|c|}{ Áreas } & \multirow{3}{*}{$\begin{array}{c}\text { A5 (Mata } \\
\text { nativa) }\end{array}$} \\
\hline & A6 & A4 & A3 & A2 & A1 & \\
\hline & (0 anos) & (6 anos) & (8 anos) & (11 anos) & (14 anos) & \\
\hline $0-20$ & 7 & 21 & 27 & 14 & 23 & 25 \\
\hline $20-40$ & 7 & 10 & 18 & 9 & 16 & 13 \\
\hline $40-60$ & 7 & 8 & 15 & 7 & 16 & 11 \\
\hline $60-80$ & 6 & 9 & 8 & 6 & 15 & 9 \\
\hline $80-100$ & 6 & 6 & 6 & 6 & 17 & 9 \\
\hline
\end{tabular}


A partir de $60 \mathrm{~cm}$ de profundidade, observa-se que os valores de $\mathrm{MO}$ das áreas revegetadas diminuem consideravelmente em relação à superfície, exceto na área A1. Conforme já foi comentado, por tratar-se de uma zona de estabelecimento do dique, esta área foi preenchida com material mais argiloso e diferenciado que parece oferecer maiores possibilidades de nutrição para que as raízes se desenvolvam em maior profundidade. Por outro lado, o substrato não está compactado facilitando o enraizamento ao longo do perfil.

De maneira geral, os acréscimos de matéria orgânica das áreas revegetadas, observados ao longo do tempo, sugerem ganhos energéticos importantes, evidenciando um aumento substancial de até quatro vezes o teor de MO se comparado ao substrato sem revegetação.

\subsubsection{Teor de Fósforo ( $\mathrm{P}$ )}

A principal função do fósforo nos vegetais está relacionada ao armazenamento e à utilização de energia, acelerando o crescimento das raízes, a maturação dos frutos e proporcionando maior vigor às plantas. Este elemento é denominado macronutriente, $\mathrm{m}$ conjunto com o nitrogênio e o potássio, pois as plantas os consomem em quantidades relativamente grandes se comparados aos outros elementos. As plantas absorvem o fósforo na forma de íons fosfato, mas a absorção é muito afetada em meio ácido quando os fosfatos são fixados por compostos de ferro e alumínio que são de baixa solubilidade. Os solos de cerrado apresentam, naturalmente, baixo $P$, pois possuem muita caulinita e óxidos de ferro e alumínio com alto poder de fixação do fosfato. A diminuição da fixação de $\mathrm{P}$ pode ser obtida com calagem e pelo aumento de matéria orgânica, através da cobertura permanente (BERNARDI et al. 2003).

Corrêa (2006) afirma que concentrações de fósforo disponível entre 10 e 15 $\mathrm{mg} \cdot \mathrm{dm}^{-3}$ garantem o seu suprimento para a vegetação implantada sobre substratos minerados. O fósforo disponível no solo se reduz drasticamente com o tempo, após o estabelecimento de atividades agrícolas como a pastagem, sendo que uma fração está associada à presença de matéria orgânica (PRIMAVESSI, 1981). A mineração de areia, mesmo se tratando de uma atividade diferente da agrícola, requer a supressão da vegetação e da camada de solo original promovendo uma sensível 
diminuição de $\mathrm{P}$ no substrato a ser recuperado. Esta situação é observada na área A6 (sem revegetação), com valores inferiores de $\mathrm{P}$ em relação às outras áreas (Tabela 14).

Tabela 14: Teores médios de Fósforo $\left(\mathrm{mg}_{\mathrm{dm}} \mathrm{dm}^{-3}\right)$ nas áreas de estudo.

\begin{tabular}{|c|c|c|c|c|c|c|}
\hline \multirow[t]{2}{*}{\begin{tabular}{|c|}
$\begin{array}{c}\text { Profundidade } \\
(\mathrm{cm})\end{array}$ \\
\end{tabular}} & \multicolumn{5}{|c|}{ Áreas } & \multirow[b]{2}{*}{$\begin{array}{c}\text { A5 (Mat } \\
\text { nativa) }\end{array}$} \\
\hline & $\begin{array}{c}\text { A6 } \\
\text { (0 anos) }\end{array}$ & $\begin{array}{c}\text { A4 } \\
\text { (6 anos) }\end{array}$ & $\begin{array}{c}\text { A3 } \\
\text { (8 anos) }\end{array}$ & $\begin{array}{c}\text { A2 } \\
\text { (11 anos) }\end{array}$ & $\begin{array}{c}\text { A1 } \\
\text { (14 anos) }\end{array}$ & \\
\hline $0-20$ & 1,0 & 12,7 & 10,0 & 8,3 & 8,3 & 5,3 \\
\hline $20-40$ & 1,0 & 1,3 & 3,0 & 1 & 8 & 1,7 \\
\hline $40-60$ & 1,0 & 1,0 & 2,0 & 1 & 6 & 1,0 \\
\hline $60-80$ & 1,0 & 1,3 & 1,7 & 1,3 & 4,7 & 1,0 \\
\hline $80-100$ & 1,0 & 1,0 & 1,0 & 1 & 5 & 1,0 \\
\hline
\end{tabular}

Os $\mathrm{P}$ mais altos, observados na superfície, são das áreas A4 (6 anos) e A3 (8 anos) que, coincidentemente, têm as revegetações e as adubações mais recentes. Este resultado é esperado visto que o fósforo é um elemento pouco móvel no solo e permanece no local onde foi depositado (FALLEIRO et al., 2003 apud CARVALHO, 2006). A calagem e as adubações realizadas no início da revegetação, atuando em conjunto com o acréscimo observado de $\mathrm{MO}$ nas revegetações, devem ter contribuído para esta situação. Silva (2001) apud Corrêa (2006) detecta persistência dos efeitos da adubação fosfatada em solo de cerrado após oito anos de aplicação com superfosfato simples. Bernardi et al. (2003) também confirmam que o fósforo tem bom efeito residual.

De acordo com Corrêa (2006), P menores que $10 \mathrm{mg} \cdot \mathrm{dm}^{-3}$ podem ser considerados baixos. Devido ao pH muito ácido, o fósforo fica indisponibilizado para ser absorvido pelas plantas. É o caso das situações das áreas de estudo, onde não houve calagem. Na mata nativa, a presença de grande quantidade de serrapilheira e o bom conteúdo de matéria orgânica no solo devem contribuir para que este nutriente não seja o fator limitante no crescimento das plantas.

Situação semelhante aconteceu numa área degradada pela mineração de xisto pirobetuminoso. Decorridos 14 anos, o solo degradado (com $\mathrm{pH}<4$ ) tendo sido 
recomposto, corrigido, adubado e reflorestado com bracatinga (Mimosa scabrella), quando comparado com o solo sem floresta, apresentou como modificação química mais expressiva a elevação de teor de fósforo, que se aproximou da situação original (MONTOYA; MASCHIO, sem data) ${ }^{7}$.

A Tabela 14 também mostra a diferença de $P$ na superfície e nas camadas mais profundas ratificando a melhoria do conteúdo de $\mathrm{P}$ decorrente da correção e o crescimento da revegetação. Os intervalos de confiança de Bonferroni confirmam esta diferença entre as camadas (TANAKA et al. 2009).

\subsubsection{Teor de Potássio ( K )}

Este elemento confere às plantas resistência ao frio, à seca e às doenças. A presença de potássio e de outros íons nas células auxilia na manutenção da concentração osmótica necessária para conservar a turgidez celular. O potássio também é importante para a fotossíntese e na formação e transporte de carboidratos e proteínas. O potássio não faz parte dos tecidos das plantas, não participando da estrutura de nenhum composto orgânico conhecido; sua ação está restrita às reações enzimáticas colaborando na absorção de outros nutrientes e seus movimentos no interior das plantas (TROEH; THOMPSOM, 2007). O potássio presente nos tecidos vegetais não é incorporado à fração orgânica, permanecendo como íon, sendo mais rapidamente reincorporado ao solo para sua absorção pelas plantas. O IAC (1997) comenta que quando o solo é amostrado com vegetação exuberante, o resultado da análise pode subestimar $\mathrm{K}$, pois uma parte substancial pode estar na biomassa vegetal. Este fato é importante na avaliação de um solo pobre neste elemento, como o da mata nativa cujo teor é menor do que nas áreas revegetadas. A biomassa deve funcionar como fonte, uma vez que galhos e folhas mortas o liberam prontamente.

Considerando-se a concentração de $1,5 \mathrm{mmolc} . \mathrm{dm}^{-3}$ deste nutriente como sendo apropriada para o crescimento da vegetação em áreas degradadas (CORRÊA, 2006) e a faixa de 0 a 0,7 mmolc. $\mathrm{dm}^{-3}$ como muito baixa (IAC, 1997), verifica-se que os valores em todas as situações estudadas são muito baixos como mostra a Tabela 15. Na camada superficial onde ocorrem teores maiores que nas

\footnotetext{
${ }^{7}$ Avaliação da eficiência de M. scabrella na RAD. Embrapa, Florestas. Artigo fornecido pelos autores.
} 
outras profundidades, ainda assim, o conteúdo deste nutriente é mínimo. Resultados similares foram encontrados por Melo (2007) nas áreas de rejeito da mineração de cassiterita na Floresta Nacional do Jamari (RO), que também apresentam problemas de acidez, e numa área de Cerradão na Gleba Cerrado Péde Gigante por Ruggiero e Pivello (2005).

Tabela 15: Teores médios de Potássio $\left(\mathrm{mmolc}_{\mathrm{dm}}{ }^{-3}\right)$ nas áreas de estudo.

\begin{tabular}{|c|c|c|c|c|c|c|}
\hline \multirow[t]{2}{*}{$\begin{array}{c}\text { Profundidade } \\
(\mathrm{cm})\end{array}$} & \multicolumn{5}{|c|}{ Áreas } & \multirow[b]{2}{*}{$\begin{array}{c}\text { A5 (Mata } \\
\text { nativa) }\end{array}$} \\
\hline & $\begin{array}{c}\text { A6 } \\
\text { (0 anos) }\end{array}$ & $\begin{array}{c}\text { A4 } \\
\text { (6 anos) }\end{array}$ & $\begin{array}{c}\text { A3 } \\
\text { (8 anos) }\end{array}$ & $\begin{array}{c}A 2 \\
\text { (11 anos) }\end{array}$ & $\begin{array}{c}\text { A1 } \\
\text { (14 anos) }\end{array}$ & \\
\hline $0-20$ & 0,1 & 0,8 & 0,6 & 0,5 & 0,7 & 0,6 \\
\hline $20-40$ & 0,1 & 0,1 & 0,2 & 0,1 & 0,3 & 0,2 \\
\hline $40-60$ & 0,1 & 0,1 & 0,2 & 0,1 & 0,3 & 0,1 \\
\hline $60-80$ & 0,1 & 0,1 & 0,1 & 0,1 & 0,2 & 0,1 \\
\hline $80-100$ & 0,1 & 0,1 & 0,1 & 0,0 & 0,2 & 0,1 \\
\hline
\end{tabular}

$A$ área $\mathrm{A} 4$ (6 anos), com calagem mais recente, apresenta $\mathrm{K}$ mais alto, mas a tendência é de diminuição com o tempo conforme é observado nas outras áreas. Sobre o assunto, Bernardi et al. (2003) comentam que a calagem aumenta a disponibilidade de nutrientes por um tempo, mas diminui o suprimento futuro.

\subsubsection{Teor de Cálcio ( $\mathrm{Ca}$ )}

O cálcio é componente estrutural das paredes das células vegetais. A falta de cálcio restringe o crescimento das raízes e de outras partes da planta, agravando ainda mais a deficiência de outros elementos. O cálcio, em conjunto com o magnésio e o enxofre, também são considerados macronutrientes ativos na nutrição de plantas. No solo, estes elementos são abundantes e geralmente estão presentes em quantidades suficientes. Os teores muito baixos de cálcio ocorrem em solos altamente lixiviados, com baixa CTC, especialmente solos tropicais altamente intemperizados. A Tabela 16 reúne os resultados obtidos para $\mathrm{Ca}$ nas áreas estudadas. 
Tabela 16: Teores médios de Cálcio $\left(\mathrm{mmolc}_{\mathrm{dm}}{ }^{-3}\right)$ nas áreas de estudo.

\begin{tabular}{|c|c|c|c|c|c|c|}
\hline \multirow[t]{2}{*}{$\begin{array}{l}\text { Profundidade } \\
(\mathrm{cm})\end{array}$} & \multicolumn{5}{|c|}{ Áreas } & \multirow[b]{2}{*}{$\begin{array}{c}\text { A5 (Mat } \\
\text { nativa) }\end{array}$} \\
\hline & $\begin{array}{c}\text { A6 } \\
\text { (0 anos) }\end{array}$ & $\begin{array}{c}\text { A4 } \\
\text { (6 anos) }\end{array}$ & $\begin{array}{c}\text { A3 } \\
\text { (8 anos) }\end{array}$ & $\begin{array}{c}\text { A2 } \\
\text { (11 anos) }\end{array}$ & $\begin{array}{c}\text { A1 } \\
\text { (14 anos) }\end{array}$ & \\
\hline $0-20$ & 1 & 15 & 7,3 & 7,7 & 6 & 1,3 \\
\hline $20-40$ & 1 & 2,3 & 1,7 & 1,7 & 1 & 1 \\
\hline $40-60$ & 1,7 & 1,3 & 1,3 & 1,3 & 1,3 & 1 \\
\hline $60-80$ & 1,3 & 1,3 & 1 & 3,3 & 1 & 1,7 \\
\hline $80-100$ & 3,3 & 3 & 1,3 & 3 & 1 & 1 \\
\hline
\end{tabular}

O comportamento deste elemento no substrato segue aproximadamente o padrão do K (Tabela 15), com conteúdos mais altos na superfície e valores mais baixos na área sem revegetação. Mas, no caso de $\mathrm{Ca}$, as áreas revegetadas apresentam valores muito mais elevados do que a mata nativa. O calcário adicionado na calagem contém cálcio na sua composição, portanto, além de se corrigir a acidez do substrato, há também um suprimento extra deste elemento.

Segundo Primavessi (1981), o conteúdo ótimo de cálcio está relacionado com o de potássio, a autora afirma que em solos tropicais deve existir uma proporção mínima de 6:1 (Ca:K) entre estes dois elementos. O IAC (1997) aponta que teores menores que 3 mmolc. $\mathrm{dm}^{-3}$ de cálcio devem ser considerados baixos. Na Tabela 16 pode-se observar que, com exceção das camadas superficiais que receberam o calcário, praticamente todas as outras situações ao longo do perfil têm teores baixos de cálcio. Os teores na mata nativa são equivalentes com os valores apresentados na área sem revegetação.

\subsubsection{Teor de Magnésio ( Mg )}

Nas plantas o magnésio é vital para realização da fotossíntese, pois toda molécula de clorofila contém um íon de magnésio na sua estrutura, sendo também encontrado em quantidades elevadas nas sementes, e distribuído em menor quantidade em outras partes da planta. Os valores obtidos para o teor de magnésio nas áreas estudadas encontram-se na Tabela 17. 
Tabela 17: Teores médios de Magnésio $\left(\mathrm{mmolc}_{\mathrm{dm}} \mathrm{dm}^{-3}\right.$ nas áreas de estudo.

\begin{tabular}{|c|c|c|c|c|c|c|}
\hline $\begin{array}{l}\text { Profundidade } \\
\text { (cm) }\end{array}$ & & & Áreas & & & \\
\hline & $\begin{array}{c}\text { A6 } \\
\text { (0 anos) }\end{array}$ & $\begin{array}{c}\text { A4 } \\
\text { (6 anos) }\end{array}$ & $\begin{array}{c}\text { A3 } \\
\text { (8 anos) }\end{array}$ & $\begin{array}{c}\text { A2 } \\
\text { (11 anos) }\end{array}$ & $\begin{array}{c}\text { A1 } \\
\text { (14 anos) }\end{array}$ & $\begin{array}{c}\text { A5 (Mata } \\
\text { nativa) }\end{array}$ \\
\hline $0-20$ & 1 & 9 & 4,7 & 4 & 3,3 & 1 \\
\hline $20-40$ & 1 & 1,3 & 1 & 1 & 1 & 1 \\
\hline $40-60$ & 1,3 & 1 & 1 & 1 & 1 & 1 \\
\hline $60-80$ & 1 & 1 & 1 & 1,7 & 1 & 1 \\
\hline $80-100$ & 1,7 & 1,3 & 1 & 2 & 1 & 1 \\
\hline
\end{tabular}

O potássio, o cálcio e o magnésio apresentaram padrão similar de comportamento no substrato, o qual se reflete na correlação alta encontrada entre estas variáveis (Anexo A). Na Tabela 17, o magnésio também se encontra em maior quantidade na camada superficial, diminuindo sensivelmente nas camadas mais profundas. O calcário adicionado na calagem também pode conter magnésio na sua composição, determinando que as quantidades encontradas de magnésio nas áreas revegetadas sejam maiores do que na mata nativa. Segundo o IAC (1997), teores de magnésio abaixo de 4 mmolc. dm $^{-3}$ devem ser considerados baixos.

Na camada superficial, após a calagem, há uma diminuição gradativa deste elemento ao longo do tempo. Tendência similar se observa para o cálcio e o potássio. Este comportamento é comentado por Primavessi (1981), afirmando sustenta que após a calagem estes elementos básicos são gastos pela própria vegetação, enquanto outra parte vai sendo lixiviada pelas chuvas ou precipitada em formas insolúveis, de modo que a tendência do solo é ficar novamente ácido, porém ele nunca mais retorna a ser tão ácido como era antes da calagem. 


\subsubsection{Soma de bases (SB)}

A soma de bases é constituída pela soma dos cátions potássio, cálcio, magnésio contidos na solução solo. O comportamento desta variável obedece ao comportamento de cada uma das variáveis já referidas e que, mostrou-se similar. A camada superficial apresenta os maiores valores de SB e com tendência a diminuir ao longo do tempo nas áreas que receberam calagem. Esta variável também diminui sensivelmente com a profundidade, conforme os resultados reunidos na Tabela 18. $\mathrm{Na}$ área $\mathrm{A} 6$ (sem revegetação) os valores em cada camada não seguem este comportamento, provavelmente devido ao material de rejeito depositado que provém de uma mistura de diferentes profundidades. No solo da mata nativa, a SB apresenta valores muito mais baixos por conta de não ter recebido calagem e apresentar pH ácido.

A correlação obtida entre SB e teor de cálcio é 0,99 ; entre SB e teor de magnésio é 0,98 ; e entre SB e potássio é 0,73 (Anexo A).

Tabela 18: Resultados médios da Soma de Bases $\left(\mathrm{mmolc} \mathrm{dm}^{-3}\right)$ nas áreas de estudo.

\begin{tabular}{|c|c|c|c|c|c|c|}
\hline $\begin{array}{l}\text { Profundidade } \\
\text { (cm) }\end{array}$ & & & Áreas & & & \\
\hline & $\begin{array}{c}A 6 \\
\text { (0 anos) }\end{array}$ & $\begin{array}{c}\text { A4 } \\
\text { (6 anos) }\end{array}$ & $\begin{array}{c}\text { A3 } \\
\text { (8 anos) }\end{array}$ & $\begin{array}{c}A 2 \\
\text { (11 anos) }\end{array}$ & $\begin{array}{c}\text { A1 } \\
\text { (14 anos) }\end{array}$ & $\begin{array}{c}\text { A5 (Mata } \\
\text { nativa) }\end{array}$ \\
\hline $0-20$ & 2,1 & 24,8 & 12,6 & 12,2 & 10 & 3,0 \\
\hline $20-40$ & 2,1 & 3,8 & 2,9 & 2,8 & 2,3 & 2,2 \\
\hline $40-60$ & 3,1 & 2,4 & 2,5 & 2,4 & 2,6 & 2,1 \\
\hline $60-80$ & 2,4 & 2,4 & 2,1 & 5,1 & 2,2 & 2,8 \\
\hline $80-100$ & 5,1 & 4,4 & 2,4 & 5,1 & 2,2 & 2,1 \\
\hline
\end{tabular}

\subsubsection{Teor de Alumínio ( Al )}

Ao contrário dos elementos já comentados, o alumínio não é essencial para o crescimento das plantas, mesmo assim elas absorvem quantidades consideráveis 
deste elemento, que é muito abundante nos minerais do solo. No solo o íon $\mathrm{Al}^{3+}$ é considerado acidificante junto com o íon $\mathrm{H}^{+}$(TROEH; THOMPSOM, 2007).

Primavessi (1981) afirma que a maioria dos solos do Cerrado apresenta $\mathrm{pH}$ muito baixo podendo ocorrer toxidez de alumínio, mas que a vegetação neste bioma está adaptada aos solos ácidos e muitas vezes acumula alumínio. Ruggiero \& Pivello (2005) afirmam que as fisionomias do Cerrado mostram-se associadas aos maiores valores de Al nas camadas superiores do solo e sugerem que este fato pode estar relacionado ao acúmulo deste elemento por determinadas espécies vegetais tolerantes à sua presença excessiva. Comentam que há evidências de que algumas espécies têm alta capacidade de modificar o ambiente da sua rizósfera, exudando uma variedade de componentes orgânicos que podem formar um complexo com os íons de alumínio na solução solo e assim reduzir a fitotoxicidade deste elemento. Corrêa (2006) indica que espécies do Cerrado das famílias Cluseaceae, Melastomataceae e Vochysiaseae não se desenvolvem satisfatoriamente com calagem, porque necessitam de solos ácidos e de alumínio trocável. De tal modo a toxicidade por alumínio não parece ser um fator limitante para o desenvolvimento da vegetação na área A5 de mata nativa. Os resultados observados na Tabela 19 sugerem que, nos estágios mais jovens da revegetação este teor deve manter-se baixo e não dificultar o crescimento das mudas. No decorrer do tempo seu efeito será nulo caso a escolha das espécies tenha sido adequada, ou seja, estão adaptadas à situação do ambiente local.

Tabela 19: Teores médios de Alumínio $\left(\mathrm{mmolc}_{\mathrm{dm}}{ }^{-3}\right)$ nas áreas de estudo.

\begin{tabular}{|c|c|c|c|c|c|c|}
\hline $\begin{array}{l}\text { Profundidade } \\
(\mathrm{cm})\end{array}$ & & & Áreas & & & \\
\hline & $\begin{array}{c}\text { A6 } \\
\text { (0 anos) }\end{array}$ & $\begin{array}{c}\text { A4 } \\
\text { (6 anos) }\end{array}$ & $\begin{array}{c}\text { A3 } \\
\text { (8 anos) }\end{array}$ & $\begin{array}{c}A 2 \\
\text { (11 anos) }\end{array}$ & $\begin{array}{c}\text { A1 } \\
\text { (14 anos) }\end{array}$ & $\begin{array}{c}\text { A5 (Mata } \\
\text { nativa) }\end{array}$ \\
\hline $0-20$ & 7 & 4 & 8,7 & 4,3 & 8,7 & 13,3 \\
\hline $20-40$ & 7 & 9,3 & 10,3 & 8,7 & 11,7 & 10,3 \\
\hline $40-60$ & 6,3 & 8,7 & 11,0 & 8,3 & 11,3 & 10 \\
\hline $60-80$ & 6 & 8 & 9,3 & 1 & 11,7 & 10 \\
\hline $80-100$ & 6,3 & 5,7 & 7,3 & 0 & 12,3 & 10,3 \\
\hline
\end{tabular}


A área A1 (14 anos) apresenta teores de alumínio que se mantêm ao longo do perfil. Seu substrato, com maior conteúdo de argila, Ihe confere maior CTC e em conseqüência também apresenta maior capacidade de adsorver este elemento. $O$ estéril depositado na área A6 (sem revegetação) formava anteriormente parte do subsolo da mata nativa, portanto é provável que o Al contido tenha sido retirado por lixiviação até atingir os valores atuais. Os valores de $\mathrm{Al}$ ao longo do perfil apresentam ligeira tendência a aumentar com a profundidade, embora haja locais pontuais onde este elemento é quase nulo.

Identifica-se forte correlação linear negativa $(-0,93)$ do teor de $\mathrm{Al}$ com $\circ \mathrm{pH}$ (Anexo A).

\subsubsection{Acidez potencial $(\mathrm{H}+\mathrm{Al})$}

Tratam-se dos cátions responsáveis pela acidez no solo. Os dados obtidos são mostrados na Tabela 20 e complementam as informações da Tabela 19. O íon $\mathrm{H}^{+}$é o cátion dominante no processo, apresentando a maior carga ou participação em relação ao íon $\mathrm{Al}^{3+}$. Os valores mais altos se encontram na camada superficial, com tendência a diminuírem com a profundidade. Quanto mais antiga a revegetação constata-se que a acidez tende a aumentar, confirmando os comentários realizados para o caso do Al.

Tabela 20: Acidez Potencial ( $\mathrm{H}+\mathrm{Al})$ média $\left(\mathrm{mmolc}_{\mathrm{dm}}{ }^{-3}\right)$ nas áreas de estudo.

\begin{tabular}{|c|c|c|c|c|c|c|}
\hline $\begin{array}{c}\text { Profundidade } \\
(\mathrm{cm})\end{array}$ & & & Áreas & & & \\
\hline & $\begin{array}{c}A 6 \\
\text { (0 anos) }\end{array}$ & $\begin{array}{c}\text { A4 } \\
\text { (6 anos) }\end{array}$ & $\begin{array}{c}\text { A3 } \\
\text { (8 anos) }\end{array}$ & $\begin{array}{c}\text { A2 } \\
\text { (11 anos) }\end{array}$ & $\begin{array}{c}\text { A1 } \\
\text { (14 anos) }\end{array}$ & $\begin{array}{c}\text { A5 (Mata } \\
\text { nativa) }\end{array}$ \\
\hline $0-20$ & 20 & 28 & 56 & 21 & 57 & 73 \\
\hline $20-40$ & 18 & 23 & 52 & 22 & 60 & 34 \\
\hline $40-60$ & 17 & 20 & 46 & 21 & 54 & 33 \\
\hline $60-80$ & 17 & 22 & 22 & 11 & 53 & 34 \\
\hline $80-100$ & 16 & 12 & 15 & 10 & 53 & 28 \\
\hline
\end{tabular}




\subsubsection{Capacidade de troca catiônica ( CTC )}

A capacidade de troca catiônica (CTC) reflete a capacidade de armazenamento dos cátions pelo solo, mantendo-os disponíveis para as plantas. Está relacionada com a quantidade de matéria orgânica $(\mathrm{MO})$ e com o conteúdo de argilas no solo. A CTC é maior na porção do solo onde se tenha maior concentração de raízes. Se o meio não tiver muita influência da $\mathrm{MO}$, a CTC é proporcional ao seu teor de argila. Um solo arenoso apresenta até $50 \mathrm{mmolc} \mathrm{dm}^{-3} \mathrm{de} \mathrm{CTC}^{8}$

A Tabela 21 apresenta os resultados experimentais desta variável. No caso da mata nativa em estudo, mesmo sendo um solo arenoso, a porção superficial apresenta valor de CTC elevado (maior que $50 \mathrm{mmolc} . \mathrm{dm}^{-3}$ ), avaliando-se que há grande influência da MO no aporte de sítios de troca de cátions. O comentário é similar para as revegetações em estudo. Tais afirmações estão de acordo com o comentário de Bernardi et al. (2003) de que a matéria orgânica é responsável por $88 \%$ da CTC do solo no Cerrado. Primavessi (1981) indica valores de CTC para Cerrado entre 25 e 85 mmolc. $\mathrm{dm}^{-3}$ considerando-os extremamente baixos.

Tabela 21: Resultados médios da Capacidade de Troca Catiônica (mmolc. $\mathrm{dm}^{-3}$ ) nas áreas de estudo.

\begin{tabular}{|c|c|c|c|c|c|c|}
\hline $\begin{array}{l}\text { Profundidade } \\
(\mathrm{cm})\end{array}$ & & & Áreas & & & \\
\hline & $\begin{array}{c}A 6 \\
\text { (0 anos) }\end{array}$ & $\begin{array}{c}\text { A4 } \\
\text { (6 anos) }\end{array}$ & $\begin{array}{c}\mathrm{A3} \\
\text { (8 anos) }\end{array}$ & $\begin{array}{c}\text { A2 } \\
\text { (11 anos) }\end{array}$ & $\begin{array}{c}\text { A1 } \\
\text { (14 anos) }\end{array}$ & $\begin{array}{c}\text { A5 (Mata } \\
\text { nativa) }\end{array}$ \\
\hline $0-20$ & 21,8 & 52,8 & 68,9 & 32,9 & 66,7 & 76,3 \\
\hline $20-40$ & 20,1 & 27,1 & 55,2 & 25,1 & 62,3 & 36,6 \\
\hline $40-60$ & 20,5 & 22,8 & 48,5 & 23,8 & 56,9 & 35,4 \\
\hline $60-80$ & 19,4 & 24,8 & 24,5 & 16,1 & 55,6 & 36,8 \\
\hline $80-100$ & 21,5 & 16,8 & 17,8 & 15,1 & 55,5 & 30,1 \\
\hline
\end{tabular}

\footnotetext{
${ }^{8}$ Informação técnica obtida do Consultor Engenheiro Florestal Dr. Ronaldo de Arruda Silveira da RR Agroflorestal LTDA.
} 
Os baixos valores de SB encontrados na Tabela 18, nas situações onde não houve calagem, confirmam que a ocupação da CTC é na sua maioria de cátions hidrogênio, fato confirmado pela alta correlação entre CTC e H+Al $(0,97)$ do Anexo A. Estas circunstâncias conferem à condição do solo da mata nativa e ao substrato das áreas revegetadas como sendo pobres em nutrientes e altamente ácidos. Tal situação aponta para a necessidade de correção e calagem quando do estabelecimento de vegetação.

O gráfico de dispersão da Figura 6 permite visualizar a relação entre a CTC e o teor de matéria orgânica $(\mathrm{MO})$ na camada superficial $(0-20 \mathrm{~cm})$. Nas ordenadas estão os valores da CTC (variável resposta) e nas abscissas têm-se os valores da MO (variável explicativa). Cada ponto no gráfico representa uma trincheira diferente e a cor do ponto indica a área à qual esse ponto pertence. $O$ total é de 18 pontos no gráfico correspondendo às 18 amostras de solo na camada superficial.

$\mathrm{Na}$ Figura 6 observa-se a existência de uma associação positiva entre as variáveis referidas, nessa profundidade (Correlação CTC,MO $=0,9103$ ). Para a variável soma de bases (SB), ao contrário do caso anterior, não se verificou uma tendência linear positiva com a CTC.

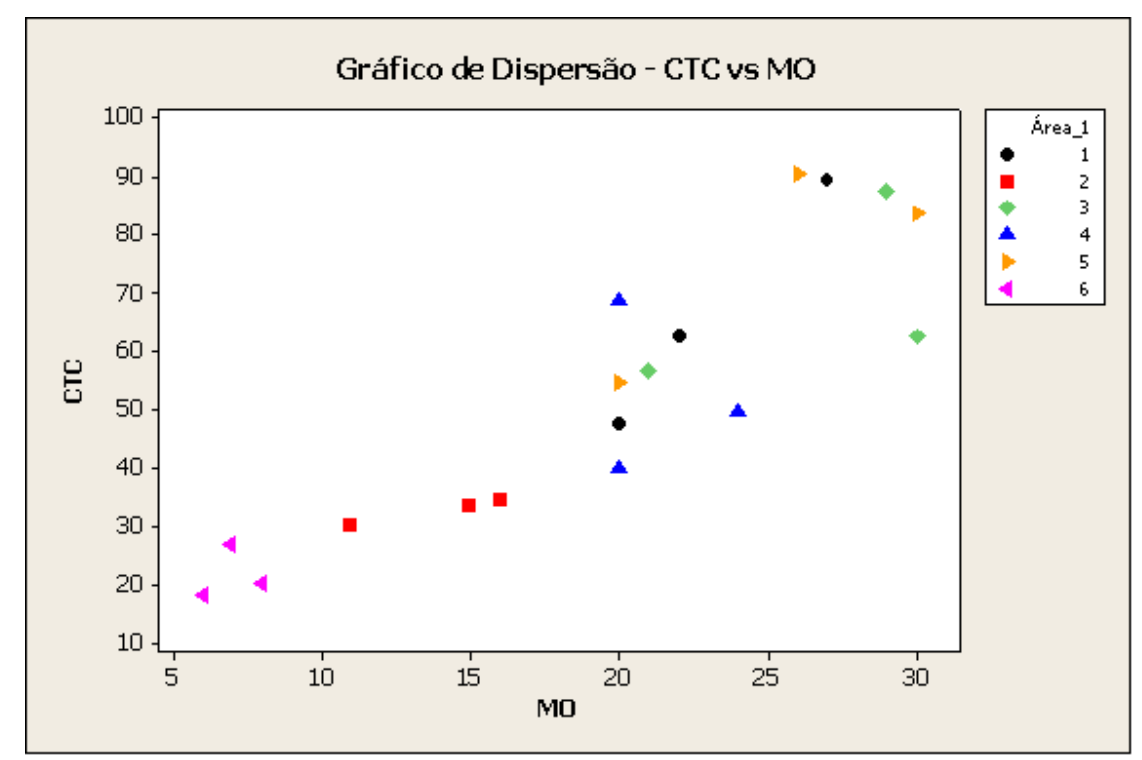

Fonte: Tanaka et al. (2009)

Figura 7: Gráfico de dispersão CTC x MO na camada superficial. 
O fato de que a MO contribui positivamente no valor de CTC é confirmado pela análise de regressão indicando que estas duas variáveis estão linearmente relacionadas entre si e têm bom ajuste do modelo de regressão. A análise também ratifica que a SB não está ligada a CTC (TANAKA et al. 2009).

\subsubsection{Porcentagem de Saturação de Bases ( V )}

Trata-se da porcentagem de sítios de troca de cátions ocupada por bases e cujos valores experimentais obtidos encontram-se na Tabela 22. Esta variável é uma boa medida da quantidade da CTC que está sendo utilizada para estocar nutrientes. Sua determinação é feita mediante a expressão (6).

Quando uma base é adicionada ao solo, como no caso da calagem, os íons de $\mathrm{H}^{+}$das micelas são substituídos por cátions de base e movem-se para a solução solo onde reagem com os íons $\mathrm{OH}^{-}$e formam água. Nesta situação ocorre uma mudança na porcentagem de sítios de permuta de cátions ocupados pelo $\mathrm{H}^{+}$versus aqueles ocupados pelas bases; neste caso a porcentagem de saturação de bases foi incrementada. Esta é a situação que deve ocorrer na camada superficial das revegetações, que comparadas à mata nativa, tiveram um incremento acentuado.

Um dos métodos de cálculo da quantidade de corretivo a ser adicionado, que é amplamente utilizado para solos de Cerrado, considera a elevação da saturação de bases para um valor ideal (CORRÊA, 2006).

Tabela 22: Porcentagem média de Saturação de Bases (\%) nas áreas de estudo.

\begin{tabular}{|c|c|c|c|c|c|c|}
\hline \multirow[t]{2}{*}{$\begin{array}{l}\text { Profundidade } \\
(\mathrm{cm})\end{array}$} & \multicolumn{5}{|c|}{ Áreas } & \multirow[b]{2}{*}{$\begin{array}{c}\text { A5 (Mata } \\
\text { nativa) }\end{array}$} \\
\hline & $\begin{array}{c}\text { A6 } \\
\text { (0 anos) }\end{array}$ & $\begin{array}{c}\text { A4 } \\
\text { (6 anos) }\end{array}$ & $\begin{array}{c}\text { A3 } \\
\text { (8 anos) }\end{array}$ & $\begin{array}{c}A 2 \\
\text { (11 anos) }\end{array}$ & $\begin{array}{c}\text { A1 } \\
\text { (14 anos) }\end{array}$ & \\
\hline $0-20$ & 10 & 43 & 20 & 37 & 16 & 4 \\
\hline $20-40$ & 10 & 15 & 5 & 11 & 4 & 6 \\
\hline $40-60$ & 15 & 12 & 7 & 10 & 5 & 6 \\
\hline $60-80$ & 12 & 12 & 10 & 32 & 4 & 8 \\
\hline $80-100$ & 23 & 25 & 14 & 33 & 4 & 7 \\
\hline
\end{tabular}


O IAC (1997) fornece como valores de referência até $25 \%$, como sendo muito baixo, e baixo entre 26 e 50\% para esta variável. As áreas em estudo mostram níveis de baixos a muito baixos. Comparativamente, todas as áreas revegetadas melhoraram $\circ \mathrm{V}$ em relação à área sem revegetação e ficaram ainda melhores que a mata nativa. A saturação de bases apresenta aumento considerável após a calagem, com tendência a diminuir na medida que aumenta o tempo de revegetação. $\mathrm{O}$ valor muito baixo de $\mathrm{V}$ da mata nativa reflete o fato da própria vegetação conter a maioria dos nutrientes, estocados na biomassa e na serrapilheira. A ciclagem de nutrientes e a mineralização são processos que devem estar bem estabelecidos e concedem à área sua auto-sustentabilidade. Em contrapartida, demonstra-se que as áreas sem revegetação (A6), mesmo preparados e com adição de solo superficial resultam muito pobres em nutrientes, reforçando a importância da calagem, da adubação para o suprimento dos mesmos.

Determina-se uma correlação linear positiva alta entre $\mathrm{V}$ e $\mathrm{pH}(0,82)$ e entre $\mathrm{V}$ e SB $(0,73)$; identifica-se uma correlação negativa alta entre $\mathrm{V}$ e Al $(-0,83)$ (Anexo A).

\subsection{Resultados e análise das observações da vegetação}

O estado geral da revegetação numa área degradada constitui um indicador básico da recuperação no local e reflete as condições ambientais determinantes do desenvolvimento das plantas. No conhecimento do estado das plantas utiliza-se a altura e a circunferência à altura do peito (CAP), observando-se as diferenças entre as áreas estudadas e verificando-se a riqueza de diversidade de espécies. No método de monitoramento proposto será necessário estabelecer uma conexão entre a situação físico-química do substrato e as condições da vegetação, buscando-se compreender aspectos sinérgicos entre ambos que determinam 0 seu desenvolvimento.

$\mathrm{Na}$ análise comparativa das variáveis de vegetação, o primeiro passo foi a definição de um critério para trabalhar com a grande quantidade de espécies arbóreas. Constatou-se em campo que os dosséis não são contínuos e que o desenvolvimento das espécies dentro das áreas de estudo é muito diversificado, decidindo-se então agrupar os resultados de CAP e altura por espécie em cada área de estudo. Para isso, observou-se o número de exemplares de cada espécie e, 
dentre as mais populosas, verificou-se as que estavam presentes em pelo menos 4 áreas.

Um aspecto relevante é que as espécies resultantes dessa classificação não contemplavam espécies presentes na área A5 de mata nativa. Foram então incluídas as espécies mais populosas desta área, adicionando-se seis novas espécies. As espécies que não se enquadravam nessas duas condições anteriores foram agrupadas em uma única categoria denominada outras.

A Tabela 23 ilustra as espécies consideradas para a classificação, sendo que as espécies Nectandra cuspidata (Canelão), Copaifera langsdorffii (Copaíba), Mollinedia schottiana (Fedido), Tapirira guianenesis (Peito de pomba), Xylopia aromática (Pindaíba de macaco) e Rapanea umbelatta (Pororoca) são encontradas predominantemente na área A5 (mata nativa).

Tabela 23: Espécies arbóreas mais freqüentes nas áreas de estudo.

\begin{tabular}{clc}
\hline Espécie & \multicolumn{1}{c}{ Nome da Espécie } & $\begin{array}{c}\text { Total de } \\
\text { exemplares }\end{array}$ \\
\hline 1 & Peltophorum dubium (Canafístula) & 56 \\
2 & Schinus terebentifolium (Aroeira pimenteira) & 55 \\
3 & Acacia polyphilla (Monjoleiro) & 54 \\
4 & Lafoensia pacari (Dedaleiro) & 54 \\
5 & Psidium guajaba (Goiabeira) & 38 \\
6 & Inga edulis (Ingá) & 34 \\
7 & Enterolobium contortisiliquum (Timburí) & 33 \\
8 & Psudobombax manguba (Manguba) & 30 \\
9 & Jacaranda micrantha (Caroba) & 29 \\
10 & Croton floribundus (Capinxingui) & 25 \\
11 & Hymenaea stigonocarpa (Jatobá) & 15 \\
12 & Inga uruguensis (Ingá banana) & 15 \\
13 & Pterogyne nitens (Amendoim) & 9 \\
14 & Luehea paniculata (Açoita-cavalo) & 9 \\
15 & Tabebuia cassineoides (Ipé amarelo) & 8 \\
16 & Nectandra cuspidata (Canelão) & 18 \\
17 & Copaifera langsdorffii (Copaíba) & 32 \\
18 & Mollinedia schottiana (Fedido) & 21 \\
19 & Tapirira guianensis (Peito de pomba) & 20 \\
20 & Xylopia aromatica (Pindaíba de Macaco) & 13 \\
21 & Rapanea umbellata (Pororoca) & 14 \\
22 & Outras & 238 \\
\hline & & 820 \\
\hline
\end{tabular}


A partir dessa classificação, foram calculadas as medidas resumo das variáveis CAP e altura para cada espécie contemplada. Essas medidas estão apresentadas no Anexo E e serviram como base para a elaboração das tabelas mostradas a continuação.

\subsubsection{Circunferência à altura do peito (CAP)}

Da Tabela 24 observa-se que a espécie Enterolobium contortisiliqum (Timburí) apresenta os maiores valores médios de CAP em todas as áreas em que está presente; também se destaca Acacia polyphilla (Monjoleiro). De modo geral, os exemplares com maior circunferência do tronco pertencem às espécies agrupadas na categoria outras, o qual significa que o maior desenvolvimento na CAP está entre as espécies com poucos indivíduos, como é o caso de Ouratea semiserrata (Castanheira), Chorisia especiosa (Paineira), Adenanthera peregrina (Angico), Adenanthera macrocarpa (Angico vermelho), Adenanthera falcata (Angico cascudo), entre outros. As espécies cujas caselas apresentam o símbolo "““ não estão presentes na área em questão.

$\mathrm{Na}$ Tabela 24 o comportamento das espécies na área A2 reflete uma quebra de linearidade no desenvolvimento da vegetação. Espera-se que quanto mais antiga a idade de revegetação maiores serão os valores de CAP. Porém, na área A2, os valores de CAP são inferiores ao da área A3. As exceções para esse fato são as espécies Enterolobium contortisiliquum, Psidium guajaba (Goiabeira) e Luehea paniculata (Açoita-cavalo). No caso da mata nativa, verificou-se uma alta densidade de plantas (número de espécies/área) que influencia o hábito de crescimento de algumas espécies arbóreas. Observam-se troncos finos e tendência no crescimento de trepadeiras. Nas áreas revegetadas a densidade é menor e, com exceção da área A1 (14 anos), ainda se distingue com clareza a distância de plantio realizado entre as mudas. Esta situação permite o crescimento mais acentuado da circunferência dos troncos.

O Apêndice $E$ exibe a existência de algumas espécies com alta variabilidade nas medidas observadas, como é o caso do Croton floribundus (Capixingui) da área A1, cujo exemplar de tronco mais fino apresenta CAP de $5 \mathrm{~cm}$ enquanto que o mais 
largo apresenta a medida de $57 \mathrm{~cm}$. Este aspecto é favorável, pois reflete diferentes idades e demonstra a existência de indivíduos jovens, resultado da regeneração natural.

Tabela 24: Circunferência à altura do peito (CAP) média $(\mathrm{cm})$ das espécies arbóreas mais freqüentes nas áreas de estudo.

\begin{tabular}{|c|c|c|c|c|c|}
\hline \multirow[t]{2}{*}{ Espécie arbórea } & \multicolumn{5}{|c|}{ Áreas } \\
\hline & $\begin{array}{c}\mathrm{A1} \\
\text { (14 anos) }\end{array}$ & $\begin{array}{c}\mathrm{A} 2 \\
\text { (11 anos) }\end{array}$ & $\begin{array}{c}\text { A3 } \\
\text { (8 anos) }\end{array}$ & $\begin{array}{c}\text { A4 } \\
\text { (6 anos) }\end{array}$ & $\begin{array}{c}\mathrm{A5} \\
\text { (Mata nativa) }\end{array}$ \\
\hline Peltophorum dubium & 20,8 & 17,2 & 22,3 & 16,5 & - \\
\hline Schinus terebentifolius & 20,8 & 11,9 & 17,3 & 13,7 & - \\
\hline Acacia polyphilla & 39,4 & 9,8 & 34,6 & 17,7 & - \\
\hline Lafoensia pacari & 17 & 12,4 & 13,0 & 8,3 & - \\
\hline Psidium guajaba & 11,6 & 14,6 & 11,1 & 9,3 & - \\
\hline Inga edulis & 15,7 & 10,3 & 21 & 19,5 & - \\
\hline Enterolobium contortisiliqum & - & 34,4 & 39 & 33 & - \\
\hline Psudobombax manguba & 17,9 & 11,9 & 20 & 9 & - \\
\hline Jacaranda micrantha & 14,4 & 5 & 10 & 18 & - \\
\hline Croton floribundus & 26,9 & 15,9 & 15 & - & - \\
\hline Hymenaea stigonocarpa & 14,5 & 6,3 & 10,5 & - & - \\
\hline Inga uruguensis & 18,7 & 14,5 & 28,7 & 7,4 & - \\
\hline Tipuana speciosa & 27,5 & - & 9,83 & 8 & - \\
\hline Luehea paniculata & 8 & 7,67 & 15 & 10,7 & - \\
\hline Tabebuia cassineoides & 18 & 6 & 9 & 9,3 & - \\
\hline Nectandra cuspidata & - & - & - & - & 12,4 \\
\hline Copaifera langsdorffii & - & - & 11 & - & 15,9 \\
\hline Mollinedia schottiana & - & - & 7 & - & 7,7 \\
\hline Tapirira guianensis & - & - & - & 13 & 32,1 \\
\hline Xylopia aromatica & - & - & - & 14 & 23,3 \\
\hline Rapanea umbellata & - & - & - & - & 14,6 \\
\hline Outras & 22,7 & 19,4 & 19,0 & 8,7 & 15,7 \\
\hline
\end{tabular}

\subsubsection{Altura}

No Apêndice $E$ observa-se que, para a altura, não há muita variabilidade nos dados como no caso da variável CAP, indicando maior homogeneidade da altura entre os exemplares analisados dentro de cada área. Já na Tabela 25 com as alturas médias de todas as áreas, os menores valores médios de altura obtidos são verificados para as espécies Tabebuia casineoides (Ipê amarelo) e Hymenaea 
stigonocarpa (Jatobá), ambas pertencentes à área A2 (11 anos). As plantas mais altas são encontradas, em geral, no grupo da categoria outras e aquelas espécies selecionadas que são predominantes na área A5 (mata nativa).

Tabela 25: Altura média $(\mathrm{m})$ das espécies arbóreas mais freqüentes nas áreas de estudo

\begin{tabular}{lccccc}
\hline Espécie arbórea & \multicolumn{5}{c}{ Áreas } \\
\cline { 2 - 6 } & $\begin{array}{c}\text { A1 } \\
\text { (14 anos) }\end{array}$ & $\begin{array}{c}\text { A2 } \\
\text { (11 anos) }\end{array}$ & $\begin{array}{c}\text { A3 } \\
\text { (8 anos) }\end{array}$ & $\begin{array}{c}\text { A4 } \\
\text { (6 anos) }\end{array}$ & $\begin{array}{c}\text { A5 } \\
\text { (Mata } \\
\text { nativa) }\end{array}$ \\
\hline Peltophorum dubium & 5,6 & 3,87 & 6,12 & 4,65 & - \\
Schinus terebentifolium & 5,08 & 2,94 & 4,98 & 3,88 & - \\
Acacia polyphilla & 7,77 & 2,76 & 7,96 & 4,22 & - \\
Lafoensia pacari & 5,33 & 3,14 & 4,58 & 2,96 & - \\
Psidium guajaba & 4,43 & 3,66 & 4,04 & 2,94 & - \\
Inga edulis & 4,63 & 3,17 & 5,75 & 4,9 & - \\
Enterolobium contortisiliqum & - & 4 & 6,45 & 5,29 & - \\
Psudobombax manguba & 6,47 & 3,15 & 4,13 & 2,9 & - \\
Jacaranda micrantha & 4,89 & 2 & 5,5 & 3,8 & - \\
Croton floribundus & 6,15 & 3,86 & 5 & - & - \\
Hymenaea stigonocarpa & 5,98 & 1,9 & 4,05 & - & - \\
Inga uruguensis & 5,7 & 3,93 & 8,33 & 2,68 & - \\
Tipuana speciosa & 7,75 & - & 4,25 & 2,6 & - \\
Luehea paniculata & 3,5 & 2,6 & 3,6 & 2,67 & - \\
Tabebuia cassineoides & 4,5 & 1,5 & 2,3 & 2,5 & - \\
Nectandra cuspidata & - & - & - & - & 5,4 \\
Copaifera langsdorffii & - & - & 4,55 & - & 5,34 \\
Mollinedia schottiana & - & - & 2,8 & - & 4,19 \\
Tapirira guianensis & - & - & - & 4 & 7,56 \\
Xylopia aromatica & - & - & - & 4,1 & 6,57 \\
Rapanea umbellata & - & - & - & - & 5,67 \\
Outras & 5,55 & 3,65 & 5,12 & 3,03 & 5,22 \\
\hline
\end{tabular}

Tanto para CAP (Tabela 24), como para altura (Tabela 25), os valores médios observados da maioria das espécies na área A2 (11 anos) são menores que até na área A4 (6 anos) com revegetação mais recente. Este comportamento nas plantas coincide com as condições menos favoráveis do substrato. 
Uma amostra correspondente às médias de altura e CAP das três espécies arbóreas mais freqüentes pode ser observada na Figura 8. O menor desempenho das árvores é na área A2, a qual também apresenta as condições menos favoráveis no substrato como é mostrado na Figura 9 com os exemplos de Ds e MO.

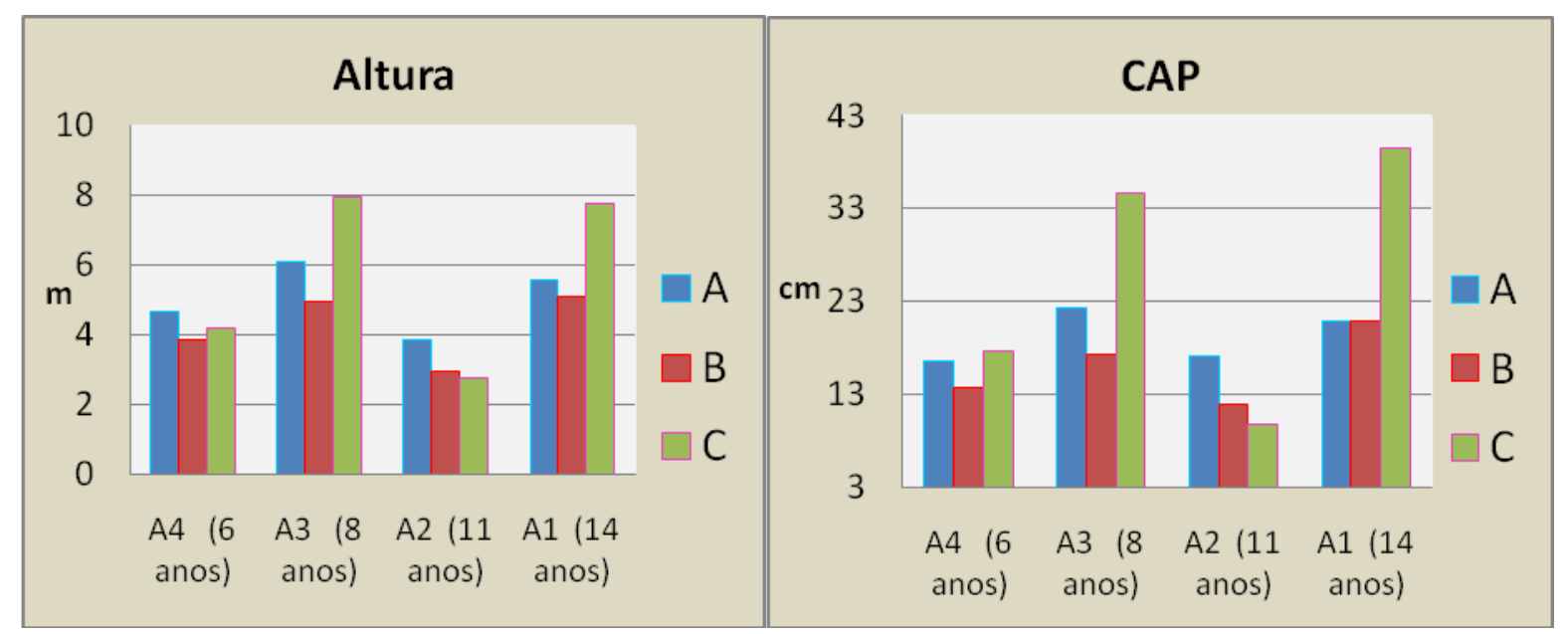

Figura 8: Médias de Altura e CAP das três espécies arbóreas mais frequentes nas áreas revegetadas. A: Peltophorum dubium (Canafístula), B: Schinus terebentifolius (Aroeira pimenteira) e C: Acacia polyphilla (Monjoleiro).

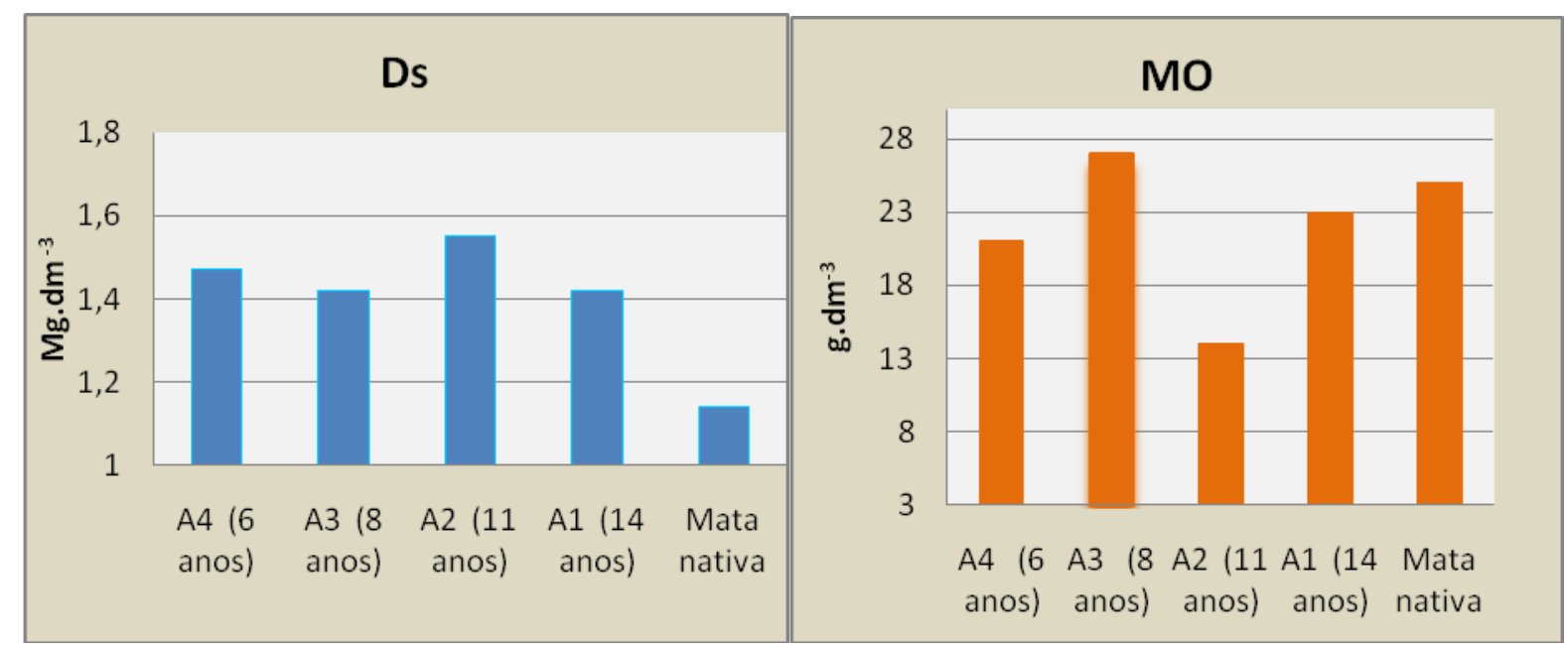

Figura 9: Densidade de solo (Ds) e teor de matéria orgânica (MO) na camada superficial das áreas revegetadas e da mata nativa. 


\subsubsection{Diversidade}

O Apêndice $A$ mostra as tabelas das espécies identificadas em cada área de estudo. Considerando as áreas revegetadas pode-se constatar que a área $A 3$ apresenta maior número de espécies, com algumas que só foram plantadas nesse local, tais como Cabralea canjerana (Canjarana), Ouratea semisserrata (Castanheira), Mollinedia schottiana (Fedido), Aloysia virgata (Lixeira), Guazuma ulmifolia (Guaxumá branca), Tabebuia alba (Ipê mandioca), Araucaria angustifolia (Pinheiro), e Hevea brasiliensis (Seringueira). Da mesma forma, a área A1 apresenta algumas espécies diferentes da área $\mathrm{A} 2$ e da área A4. As tabelas também evidenciam claramente a diferencia na composição florística entre a mata nativa e as áreas revegetadas. Há poucas espécies em comum e esta situação deve estar relacionada à disponibilidade de mudas na ocasião do plantio em cada área. Nave (2009) manifesta que, até finais da década de 90, a maioria dos viveiros não produzia mais que 30 espécies, com proporções desiguais entre elas e de forma irregular ao longo do ano. Além disso, há dificuldades técnicas para produzir mudas das espécies de Cerrado devido à baixa taxa de germinação e longevidade das sementes (DURIGAN, 2009). Atualmente o problema pode ser amenizado com técnicas propostas e ratificadas por Nave (2005), como o resgate de plântulas e de chuva de sementes dos próprios locais que irão ser desmatados pelo avanço da lavra.

A diversidade nas áreas de estudo determinada pelo Índice de ShannonWiener foi proporcionada por Tanaka et al. (2009) e é mostrada na Tabela 26. A riqueza de espécies contribui positivamente no valor do índice: quanto maior o número de espécies, maior o valor do índice. Para o seu cálculo desconsidera-se a classificação das espécies pelas categorias definidas anteriormente. Como o intuito do índice é verificar a riqueza de diversidade da vegetação, todas as espécies, por mais que apresentem um número reduzido de exemplares, devem ser consideradas no cálculo. Obtiveram-se os valores para cada combinação de área e parcela apresentada na Tabela 26. Em destaque na tabela, pode-se ver o maior valor encontrado para o índice na casela referente à parcela 1 da área A5 (mata nativa), e o menor valor calculado corresponde à parcela 5 da área A3 (8 anos). A mata nativa detém a maior diversidade, apesar de não se ter realizado a amostragem completa, pois somente foram levantados dados para duas parcelas. Um levantamento com 
amostragem de 3 parcelas circulares com $10 \mathrm{~m}$ de raio feito no EIA pela PA Brasil (2008) identificou 51 espécies arbóreas na mesma área, com dominância das famílias Leguminoseae, Bignoniaceae, Anonaceae e Myrtaceae.

$\mathrm{Na}$ área $\mathrm{A} 3$, embora haja riqueza de espécies, a existência em grande número de exemplares de uma única espécie (dominância) pode estar provocando influência negativa no valor do índice. É o caso da quantidade elevada de indivíduos de Inga edulis na parcela 5 desta área.

O principal propósito em mostrar os resultados obtidos com este índice é ressaltar o avanço oriundo das ações de revegetação. Considerando-se que, após a mineração, o índice de Shannon-Wiener é igual a zero devido à ausência de qualquer forma de vegetação. Os resultados encontrados da Tabela 26, em todas as áreas revegetadas referem-se ao ganho de diversidade, após a cessação das atividades de mineração.

\section{Tabela 26: Índice de Shannon-Wiener por parcela e por área}

\begin{tabular}{lccccc}
\hline & Parcela 1 & Parcela 2 & Parcela 3 & Parcela 4 & Parcela 5 \\
\hline Área A1 & 2,69 & 2,56 & 2,87 & 2,29 & 2,17 \\
Área A2 & 2,42 & 2,41 & 2,28 & 2,29 & 2,61 \\
Área A3 & 2,57 & 2,63 & 2,3 & 2,59 & $\mathbf{2 , 0 3}$ \\
Área A4 & 2,19 & 2,17 & 2,39 & - & 2,29 \\
Área A5 & $\mathbf{2 , 9 3}$ & 2,64 & - & - & - \\
\hline \multicolumn{5}{l}{ Fonte: Tanaka et al. (2009) }
\end{tabular}

As espécies encontradas na mata nativa demonstram que se trata de uma área de ecótono ou transição entre Cerrado e Floresta Estacional Semidecidual, portanto, estão presentes espécies destes dois ecossistemas. Dentre as 57 espécies identificadas nas áreas revegetadas, há espécies de Floresta Ombrófila Densa, de Floresta Estacional Semidecidual, de Cerrado e até exóticas. ${ }^{9}$. Quanto à classe sucessional o número de espécies pioneiras predomina, mas também há numerosa presença de não pioneiras como mostra o Apêndice $A$.

Constata-se um grande número de espécies crescendo com vigor, mesmo com uma composição florística pouco similar a da mata nativa do entorno e com as

\footnotetext{
${ }^{9}$ Informação obtida em consulta eletrônica à Dra. Giselda Durigan do Instituto Florestal, São Paulo.
} 
condições restritivas do substrato, quando se compara estas áreas com um solo normal. Este fato indica que se adaptaram às condições do substrato e do ambiente. Como já citado em 4.3.1 o Enterolobium contortisiliqum (Timburí) e a Acacia polyphilla (Monjoleiro) se destacam por apresentar CAP superiores que nem mesmo as espécies da mata nativa possuem. Outras espécies crescendo em boas condições são Schinus terebentifolius (Aroeira pimenteira), Peltophorum dubium (Canafístula), Jacaranda micrantha (Caroba), Croton floribundus (Capixingui), Adenanthera macrocarpa (Angico vermelho), Adenanthera falcata (Angico cascudo), Psidium gojaba (Goiabeira), Sysiguim jambos (Jambolão), Inga uruguensis (Ingá), Inga uruguensis (Ingá banana), Lafoensia pacari (Dedaleiro) e outros. Em muitos casos o bom desenvolvimento também se reflete nos numerosos rebrotamentos dos indivíduos implantados.

Pterogyne nitens (Amendoim), Tabebuia cassinoides (Ipê amarelo), Pseudobombax munguba (Manguba), Hymenaea stigonocarpa (Jatobá), Araucaria angustifolia (Araucária) são espécies que não estão se desenvolvendo satisfatoriamente, provavelmente, porque não resistem ao estresse decorrente das condições do substrato ou porque pertencem a outros biomas e não estão adaptadas às condições ambientais do local. Devido à idade longa dos plantios não foi possível identificar quais espécies tiveram maior porcentagem de mortalidade. Somente na área $\mathrm{A} 4$, verifica-se que há muitos indivíduos de Pseudobombax munguba com crescimento estagnado ou perecendo; é o caso da Hymenaea stigonocarpa na área A2.

Uma diferença marcante entre a mata nativa e áreas revegetadas refere-se à presença de sub-bosque na mata com um estrato de indivíduos arbóreos jovens e trepadeiras e ainda outro estrato de arbustos e herbáceas. Novamente neste quesito, com exceção da área $A 1$, onde já se observa um estrato ralo de indivíduos arbóreos jovens, as demais áreas apresentam poucos indivíduos de espécies arbóreas regenerantes. Herbáceas e arbustivas espontâneas aparecem com um pouco de maior freqüência, mas a braquiária tem crescimento dominante na superfície.

Um aspecto importante é a observação das espécies nativas emergindo naturalmente nas áreas revegetadas, um bom indício de que há mecanismos de dispersão de propágulos e que o substrato está proporcionando condições apropriadas à sucessão. Outro sintoma positivo é o crescimento de mudas das 
mesmas árvores introduzidas, o qual reflete que se está formando um banco com sementes viáveis, e novamente, as condições ambientais estão propícias para seu desenvolvimento. A Tabela 27 apresenta as espécies regenerantes para cada área. $\mathrm{Na}$ área $\mathrm{A} 1$ destaca-se a emergência natural de inúmeras mudas de Acacia polyphilla (Monjoleiro), Jacaranda micrantha (Caroba) e Croton floribundus (Capixingui). Nas áreas A2 e A4, excluindo Baccaris dracunculifolia (Alecrim-docampo) e Vernonia polyanthes (Assa-peixe) as demais mudas das espécies apontadas aparecem raramente. $\mathrm{Na}$ área $\mathrm{A} 3$ se destacam Copaifera langsdorffii (Copaíba), Solanum mauritanum (Fumo bravo) e Xylopia aromatica (Pindaíba de macaco), estes dois últimos com crescimento vigoroso e mais freqüente.

Tabela 27: Espécies arbóreas com emergência natural nas áreas revegetadas.

\begin{tabular}{|c|c|c|c|}
\hline Área A1 (14 anos) & Área A2 (11 anos) & Área A3 (8 anos) & Área A4 (6 anos) \\
\hline Gochnata polyforma* & Gochnata polyforma* & Acacia polyphilla & Acacia polyphilla \\
\hline Acacia polyphilla & Acacia polyphilla & Copaifera langsdorffii* & Bambú chinês \\
\hline Cassia ferruginea* & Baccaris dracunculifolia* & Inga banana & Guazuma ulmifolia* \\
\hline Copaifera langsdorffii ${ }^{\star}$ & Cabralea canjarana & Jacaranda micrantha & Jacaranda micrantha \\
\hline Croton floribundus & Croton floribundus & Peltophorum dubium & Schinus terebentifolius \\
\hline Dalbergia miscolobium & Espinhadeira & Psidium gojaba & Vernonia polyanthes* \\
\hline Espinhadeira & Mimosa caesalpineafolia & Solanum mauritanum ${ }^{*}$ & \\
\hline Jacaranda micrantha & Não identificado* & Xylopia aromatica* & \\
\hline Ocotea pulchella * & Psidium gojaba & & \\
\hline Psidium gojaba & Schinus terenbentifolius & & \\
\hline \multirow[t]{2}{*}{ Schinus terenbentifolius } & Uva japonesa & & \\
\hline & Vernonia polyanthes* & & \\
\hline
\end{tabular}

* Mudas de espécies nativas não implantadas

Uma influência negativa na diversificação florística das áreas revegetadas é a presença do Brachiaria decumbens (Capim braquiária ou braquiária) devido a sua alta capacidade competitiva e crescimento rápido, impedindo o desenvolvimento de sementes que porventura tenham germinado ou venham a germinar, sufocando o desenvolvimento das mudas já plantadas. Este fator está diminuindo o potencial natural da biodiversidade local nas áreas A2, A3 e A4, bem como em alguns trechos 
não sombreados da área $A 1$. Cabe esclarecer que a análise está considerando somente as espécies arbóreas o que não significa que outras formas de vida vegetal não sejam importantes. Qualquer ação para combater a influência negativa da braquiária na diversificação de espécies será também importante para o estabelecimento esperado de espécies nativas herbáceas, arbustivas, lianas e outras.

Conclui-se que, mesmo que a composição florística apresente pouca similaridade com o entorno, as áreas revegetadas já possuem uma comunidade vegetal bem estabelecida, com boa quantidade de espécies adaptadas às condições do substrato e que podem servir como referência para a escolha de espécies em revegetações similares posteriores. A regeneração natural já está acontecendo, mas a presença de braquiária é o filtro biótico mais atuante que dificulta o processo de diversificação da comunidade estabelecida.

\subsection{Relações entre parâmetros de solo e de vegetação}

A análise realizada nos itens anteriores evidencia que, praticamente todos os atributos físico-químicos escolhidos para o estudo apresentam, em maior ou menor grau, mudanças ao longo do tempo em razão do conjunto de atividades da revegetação, respondendo de forma clara às mudanças ocorridas no substrato. As mudanças são mais notórias na camada superficial destacando-se a situação mais desfavorável correspondente à área A6 (sem revegetação). As figuras 10 e 11 dos perfis médios do teor de matéria orgânica (MO) e da soma de bases (SB) ilustram bem esta situação. Gráficos similares de outras variáveis podem ser apreciados no Apêndice C. 


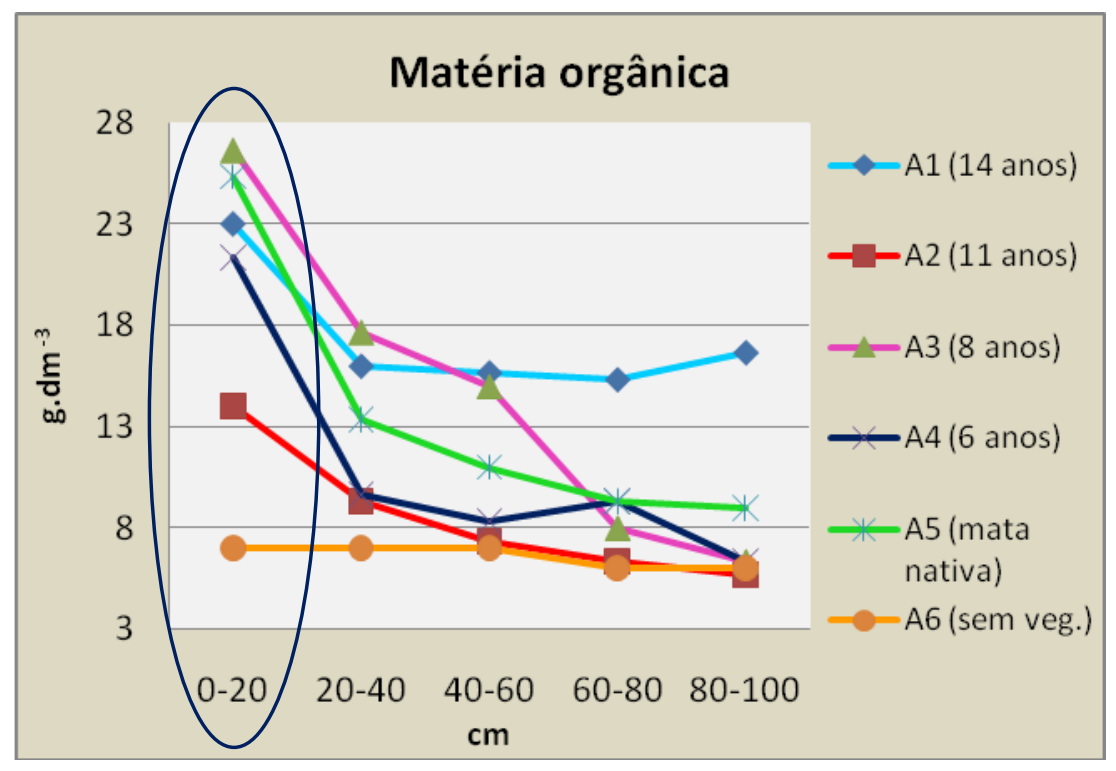

Figura 10: Perfis médios de matéria orgânica $\left(\mathrm{g} \cdot \mathrm{dm}^{-3}\right)$.

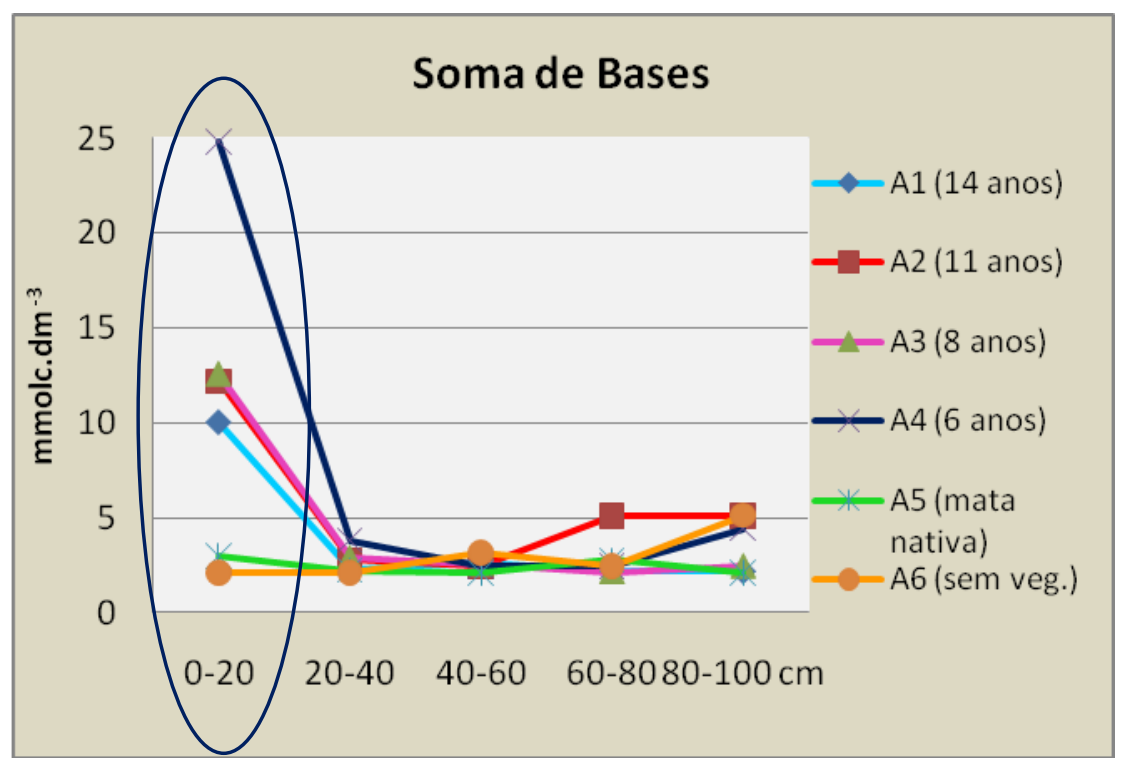

Figura 11: Perfis médios da Soma de Bases (mmolc.dm ${ }^{-3}$ ). 
As variáveis apontam comportamentos similares na evolução dos seus valores e permitem a obtenção de correlações significativas (Tabela 28). Destacamse as mais importantes: Ds e porosidade $(-0,98), \mathrm{CTC}$ e $\mathrm{MO}(0,91), \mathrm{V}$ e $\mathrm{pH}(0,82)$, Alumínio e pH $(-0,93)$ e Alumínio e V $(-0,83)$.

Tabela 28: Correlações entre as variáveis físico-químicas do substrato.

\begin{tabular}{lccccccccc}
\hline & Densidade & Porosidade & pH & MO & SB & CTC & P & V & H+Al \\
\hline Porosidade & $-0,98$ & & & & & & & & \\
pH & 0,56 & $-0,51$ & & & & & & & \\
MO & $-0,78$ & 0,76 & $-0,46$ & & & & & & \\
SB & $-0,14$ & 0,16 & 0,34 & 0,35 & & & & & \\
CTC & $-0,76$ & 0,72 & $-0,61$ & 0,91 & 0,21 & & & & \\
Fósforo (P) & $-0,48$ & 0,45 & $-0,20$ & 0,66 & 0,57 & 0,60 & & & \\
V & 0,36 & $-0,32$ & 0,82 & $-0,19$ & 0,73 & $-0,37$ & 0,20 & & \\
H+Al & $-0,74$ & 0,67 & $-0,71$ & 0,84 & $-0,03$ & 0,97 & 0,46 & $-0,55$ & \\
Al & $-0,57$ & 0,55 & $-0,93$ & 0,52 & $-0,37$ & 0,68 & 0,14 & $-0,83$ & 0,78 \\
\hline
\end{tabular}

A similaridade entre as tendências no estado do substrato e no desenvolvimento da vegetação ao longo do tempo foi comentada no item 4.3.2 e permite validar a influência do estado do substrato no vigor do crescimento da vegetação.

Com o intuito de se compreender como as mudanças do substrato se interligam com a evolução da vegetação Tanaka et al. (2009) relacionam estatisticamente as variáveis físico-químicas do substrato com as características observadas na vegetação através do modelo de análise de covariâncias multivariado. Neste modelo, busca-se avaliar simultaneamente o comportamento das variáveis CAP e altura da planta em função dos efeitos das variáveis e das covariáveis. $\mathrm{Na}$ análise, cada característica físico-química funciona como uma variável e como uma covariável. É um modelo misto que permite verificar quais são aquelas que mais influenciam na vegetação.

Este modelo estatístico também assumiu as hipóteses de normalidade testadas nas análises de resíduos. 
Uma relação importante ratificada com a análise é que a camada superficial $(0-20 \mathrm{~cm})$ do substrato é a que mais influencia no desenvolvimento da vegetação, isto significa que as plantas estão aproveitando, fundamentalmente, recursos de nutrientes e água desta camada. Este fato confirma as observações já mencionadas na discussão de resultados das variáveis físico-químicas. Há duas causas mais prováveis. Em primeiro lugar, a compactação das áreas da bacia que impedem o aprofundamento das raízes (comentado no item 4.1.2) e o outro é a questão nutricional devido à adubação e à calagem, sendo que a maioria dos nutrientes encontram-se nesta primeira camada, situação que condiciona às raízes se desenvolverem onde encontram alimento.

A análise de covariâncias multivariado também revela que a densidade (Ds), a CTC, os teores de fósforo, os teores de alumínio e o $\mathrm{pH}$ (todas na profundidade 0 - $20 \mathrm{~cm}$ ) contribuem no comportamento das duas variáveis resposta (altura e CAP da vegetação). Os resultados achados com esta ferramenta matemática precisam ser usados com parcimônia, adaptando-se os resultados com aspectos práticos e aplicáveis à situação da investigação.

A contribuição ou influência da Ds na resposta das plantas é evidente observando-se a Tabela 8 com os resultados médios de Ds nas áreas de estudo. $\mathrm{Na}$ tabela, a área A2 (11 anos) mostra a Ds média mais alta obtida na superfície. Do mesmo modo, os resultados de CAP e altura da vegetação com onze anos (Tabelas 21 e 22 respectivamente), revelam um desenvolvimento equivalente à da área A4, com apenas seis anos de revegetação. Este comportamento nas plantas coincide com as condições menos favoráveis da Ds no substrato da área A2. Estudos como os de Cunha de Assis et al. (2009) e Carvalho (2008) já mencionam as características físicas como determinantes dos parâmetros estruturais da vegetação de Cerrado. No caso, como o substrato da bacia encontra-se compactado, as práticas de manejo são importantes para o bom desenvolvimento das plantas. $\mathrm{Na}$ situação da área A2, com plantio já formado, uma opção complementar de manejo seria o uso de plantas denominadas descompactadoras de solo (PRIMAVESSI, 1981; ALVES et al., 2007) que apresentam enraizamento muito volumoso associada ao combate do crescimento agressivo da braquiária, de maneira a facilitar o estabelecimento natural de outro tipo de vegetação seja, herbácea, arbustiva ou arbórea. Corrêa et al. (2007) denomina de espécies facilitadoras da sucessão 
àquelas que poderiam acelerar o estabelecimento de outras espécies numa área minerada em recuperação.

A matéria orgânica $(\mathrm{MO})$ não está entre as variáveis selecionadas pelo modelo de covariâncias multivariado. Porém, isto não significa que esta variável não seja importante no desenvolvimento da vegetação arbórea. A sua exclusão é explicada pela correlação alta com as variáveis selecionadas, neste caso, a variável CTC (item 4.2.10). Segundo o modelo de análise, toda a influência que a CTC exerce nas variáveis altura e CAP também é identificada na variável MO. A importância da MO como componente indispensável para a recomposição vegetal em solos degradados pela mineração é mencionada por Corrêa (2006), Casagrande (2005) e Reis (2006). Entre os efeitos benéficos mais importantes da presença da $\mathrm{MO}$, citadas pelos autores, destacam-se a redução da lixiviação dos nutrientes da adubação, a melhoria da agregação e da estruturação do substrato (com aumento da porosidade), a infiltração e quantidade de água disponível para as plantas e ainda a elevação da CTC e da microbiota. Cunha de Assis et al. (2009) afirmam que solos com mais matéria orgânica têm maior capacidade de retenção de água. Estes fatores em conjunto são os mais importantes para a distribuição de espécies e para a variação florística do Cerrado, pois são responsáveis pela disponibilidade de nutrientes e de água para as plantas, agravando ou atenuando os efeitos dos períodos de seca. Os autores indicam outros estudos sobre a disponibilidade de água como a maior influência na diferenciação da fisionomia de Cerrado stricto sensu e Cerradão. (MARIMON; HARIDASAN, 2005 apud CUNHA DE ASSIS et al., 2009). Em solos locais poucos estruturados e de textura arenosa, como no substrato em estudo, a matéria orgânica tem papel relevante no aumento da retenção e disponibilidade de água. Quanto mais esforços sejam mobilizados para aumentar o teor de MO, o substrato reterá mais água e a diversificação de espécies tenderá à formação de uma fisionomia mais semelhante com a de Cerradão. Este fato possivelmente influencie mais do que as adubações ou calagem nas revegetações mais antigas. Na prática, a MO é o parâmetro mais favorável a ser conduzido no manejo visando o melhor progresso da revegetação. Ações para melhorar o teor de $\mathrm{MO}$, automaticamente irão favorecer a CTC.

O fósforo $(P)$ é um elemento limitante para o crescimento da vegetação na maioria dos solos de Cerrado (PRIMAVESSI, 1981). O substrato em estudo também se depara com esta situação, sendo muito pobre em P. Conforme consta na Tabela 
12, a área A6 (sem revegetação) apresenta teores mínimos, quase inexistentes de P. A situação se potencializa, pois, o substrato também é muito ácido. A calagem (adição de cal) e as adubações realizadas nas áreas revegetadas demonstram 0 incremento substancial nos teores de P. A adição da cal também corrige a acidez, supre o solo de cálcio e magnésio, promove o aumento da CTC e a disponibilidade da maioria dos nutrientes (IAC, 1997). A calagem limita possíveis efeitos por toxidez de alumínio que é um elemento supérfluo, sem função aparente nas plantas e abundante nos solos de Cerrado (PRIMAVESSI, 1981). Ao que tudo indica, a deficiência de $\mathrm{P}$ no substrato da bacia está ligada à acidez e à toxicidade de alumínio e estas três variáveis estão interligadas e influenciam o crescimento da vegetação.

Haridasan (1998) menciona que sementes e plântulas de Cerrado crescem mais quando são adubadas e o pH do solo é corrigido, tornando estas práticas fundamentais, principalmente, quando as plantas são mais jovens. Neste estudo, como o pH está fortemente correlacionado com a porcentagem de saturação de bases (V), é de se esperar uma melhor absorção dos nutrientes, na medida que o $\mathrm{pH}$ aumente. Na prática, a calagem e a adubação devem ser consideradas como medidas fundamentais para o sucesso da revegetação neste tipo de substrato, especialmente nos estágios mais jovens.

No monitoramento, a mensuração contínua dos parâmetros do substrato é estratégia essencial na verificação do comportamento da revegetação, proporcionando confiabilidade e segurança nos resultados. Numa hierarquia quanto à importância para a avaliação, as variáveis a serem consideradas são a MO, a Ds, o teor de $\mathrm{P}$ e o pH. Isto não significa que as outras variáveis sejam dispensáveis, mas por uma combinação de influência sobre a vegetação com o aspecto prático do manejo, as variáveis mencionadas mostram-se mais aptas para este exercício. Citase como exemplo o caso da soma de bases (SB), que está fortemente correlacionada com o pH. No entanto seu comportamento depende basicamente das ações de correção da acidez de substrato. Situação similar se apresenta com o teor de Al em que a correção ameniza possíveis efeitos daninhos.

Os resultados obtidos das variáveis selecionadas nas diversas situações do estudo devem nortear uma avaliação de desempenho da vegetação. Para tal propósito, utilizam-se os valores de referência, os níveis críticos e as taxas de reposição em relação à área sem revegetação, quase sempre com os parâmetros 
mais desfavoráveis. Os níveis críticos são estabelecidos com base na observação da evolução das variáveis e nos valores mínimos das médias encontradas nas

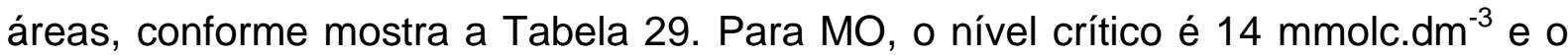
valor de referência na mata nativa $25 \mathrm{mmolc} . \mathrm{dm}^{-3}$. No caso da Ds, o nível crítico resulta 1,55 Mg.m ${ }^{-3}$ na revegetação da área $A 2$, sendo o único valor que tem uma evolução negativa em relação à área sem revegetação com Ds similar ao da mata nativa de $1,14 \mathrm{Mg} \cdot \mathrm{m}^{-3}$. No caso do $\mathrm{pH}$, como todos os valores, tanto na mata como nas áreas revegetadas são ácidos, o manejo para correção deve ser observado na implantação e nos plantios jovens. Outras variáveis foram adicionadas na tabela por serem significativas, principalmente, na implantação da vegetação.

Tabela 29: Indicadores da qualidade do substrato na revegetação da Mineração Descalvado.

\begin{tabular}{|c|c|c|c|c|c|}
\hline $\begin{array}{c}\text { Indicador da } \\
\text { qualidade do } \\
\text { substrato }\end{array}$ & $\begin{array}{c}\text { Situação mais } \\
\text { desfavorável (sem } \\
\text { revegetação) }\end{array}$ & $\begin{array}{c}\text { Valor } \\
\text { recomendado } \\
\text { p/implantação* }\end{array}$ & $\begin{array}{c}\text { Nível crítico na } \\
\text { revegetação }\end{array}$ & $\begin{array}{c}\text { Valor de } \\
\text { referência }\end{array}$ & $\begin{array}{c}\text { Taxa de } \\
\text { reposição na } \\
\text { melhor situação }\end{array}$ \\
\hline $\mathrm{MO}$ & $7 \mathrm{~g} \cdot \mathrm{dm}^{-3}$ & $10 \mathrm{~g} \cdot \mathrm{dm}^{-3}$ & $14 \mathrm{~g} \cdot \mathrm{dm}^{-3}$ & $25 \mathrm{~g} \cdot \mathrm{dm}^{-3}$ & $4 \mathrm{vezes}$ \\
\hline $\mathrm{Ds}$ & $1,14 \mathrm{Mg} \cdot \mathrm{m}^{-3}$ & $1,2 \mathrm{Mg} \cdot \mathrm{m}^{-3}$ & $1,55 \mathrm{Mg} \cdot \mathrm{m}^{-3}$ & $1,14 \mathrm{Mg} \cdot \mathrm{m}^{-3}$ & - \\
\hline $\mathrm{CTC}$ & $22 \mathrm{mmolc} \cdot \mathrm{dm}^{-3}$ & $50 \mathrm{mmolc} \cdot \mathrm{dm}^{-3}$ & $33 \mathrm{mmolc} \cdot \mathrm{dm}^{-3}$ & $76 \mathrm{mmolc} \cdot \mathrm{dm}^{-3}$ & 3 \\
\hline $\mathrm{P}$ & $1 \mathrm{mmolc} \cdot \mathrm{dm}^{-3}$ & $10 \mathrm{mmolc} \cdot \mathrm{dm}^{-3}$ & $8 \mathrm{mmolc} \cdot \mathrm{dm}^{-3}$ & $5 \mathrm{mmolc} \cdot \mathrm{dm}^{-3}$ & 12,7 \\
\hline $\mathrm{pH}$ & 4 & - & 3,8 & 3,6 & - \\
\hline $\mathrm{V}$ & $10 \%$ & $50 \%$ & $43 \%$ & $4 \%$ & 4,3 \\
\hline $\mathrm{SB}$ & $2 \mathrm{mmolc} \cdot \mathrm{dm}^{-3}$ & $25 \mathrm{mmolc} \cdot \mathrm{dm}^{-3}$ & $10 \mathrm{mmolc} \cdot \mathrm{dm}^{-3}$ & $3 \mathrm{mmolc} \cdot \mathrm{dm}^{-3}$ & 12 \\
\hline
\end{tabular}

* Obtido em referências bibliográficas.

MO: teor de matéria orgânica; Ds: densidade de solo; P: teor de fósforo, CTC: capacidade de troca catiônica; $\mathrm{V}$ : porcentagem de saturação de bases e SB: soma de bases.

Os níveis críticos dos indicadores na revegetação, na maioria dos casos, são superiores aos valores de referência, apontando situações favoráveis. Nos casos da CTC e MO não se atingiu os valores de referência, mas houve aumento das taxas de reposição em relação à área sem revegetação. 


\subsection{Avaliação de desempenho das áreas revegetadas}

O solo da mata nativa apresenta indicadores ambientais mais favoráveis que as demais situações estudadas, salientando-se maior acúmulo de serrapilheira na superfície, melhor distribuição e conteúdo de matéria orgânica, maior crescimento das raízes em profundidade e melhores condições físicas do solo ao longo do perfil traçado. Ainda que os níveis de fertilidade sejam baixos e a acidez elevada, o solo sustenta uma vegetação com bom desenvolvimento e adaptada a tais condições. As características físicas favoráveis deste solo, a boa camada de serrapilheira e a efetiva ciclagem de nutrientes permitem a melhor sustentação da vegetação natural. A maior parte da sua fertilidade vem da matéria orgânica, que sofre rápida decomposição havendo pronta absorção dos nutrientes liberados, de maneira que vão se concentrando gradualmente na biomassa e mantendo a comunidade vegetal estável.

Em comparação com a mata nativa, as áreas revegetadas apresentam menor acúmulo de serrapilheira, menor crescimento de raízes em profundidade e substrato com condições físicas desfavoráveis, devido principalmente ao efeito da compactação. No entanto, o substrato apresenta teores mais altos de fósforo, cálcio, magnésio e soma de bases, fato associado às ações de adubação e calagem realizadas na superfície do substrato por ocasião do plantio e que ainda refletem seu efeito. Quanto à situação física, constata-se que a compactação do substrato, demonstrada pelos resultados numéricos altos de densidade de solo, tem influência negativa no desenvolvimento de raízes e restringe a zona de captação de nutrientes e água. Os substratos das áreas revegetadas, quando comparados ao substrato da área ainda sem plantio, demonstram claramente que ocorreu uma melhora das condições químicas dos primeiros, ratificando os benefícios da revegetação. As práticas de reposição de solo superficial associadas aos plantios de mudas tem apresentado uma boa capacidade em criar condições ao substrato para atuar como sustentáculo da vegetação após o processo de mineração.

Quanto à vegetação, fisionomicamente a área $\mathrm{A} 1$ é a mais próxima à mata nativa, pois tem as árvores mais desenvolvidas com boa cobertura florestal, o substrato tem teores de $\mathrm{MO}$ altos e não apresenta compactação. Soma-se ainda a presença de um sub-bosque começando a se formar, conferindo-lhe um estado inicial de sucessão. A área $\mathrm{A} 2$, com os teores baixos de $\mathrm{MO}$ e compactação severa, 
presenta um desenvolvimento da vegetação equivalente ao da área A4 com 6 anos de plantio, necessitando-se, em ambas as áreas, providências para combater o crescimento invasivo de braquiária e atenuar as condições físicas menos favoráveis do substrato. A área $A 3$ com crescimento vigoroso da vegetação e o substrato com bons conteúdos de $\mathrm{MO}$ precisa apenas do controle do crescimento da braquiária. A área A4, embora com substrato compactado, apresenta teores de $\mathrm{MO}$ altos e a mata já formada (mesmo sendo a mais jovem) tem bom desenvolvimento refletindo os efeitos da calagem e adubação realizadas até quatro anos atrás.

De maneira geral as áreas revegetadas não possuem as mesmas espécies que a mata natural do entorno, no entanto muitas delas se adaptaram às condições do local. Contudo observa-se o início de uma regeneração natural que começa a contribuir com a diversificação de espécies. Essa contribuição pode ser potencializada com medidas práticas para a melhoria dos indicadores de qualidade do substrato. Desta forma, será possível criar as condições necessárias para aproximar a estrutura florística das áreas revegetadas com a da mata nativa.

Diante do objetivo principal que é a recomposição ecológica do local, as revegetações implantadas já criaram condições favoráveis e o processo sucessional está começando a acontecer, porém, em algumas circunstâncias, providências adicionais precisam ser tomadas para agilizar o povoamento espontâneo de vegetação nativa. 


\section{CAPÍtULO 5}

\section{CONCLUSÕES}

Os substratos das áreas revegetadas evoluem com o tempo e melhoram com o desenvolvimento da vegetação, sendo a camada superficial $(0-20 \mathrm{~cm})$ a mais beneficiada com acúmulos de serrapilheira, zonas com atividade de raízes e melhoria nutricional, em alguns casos, superior à da mata nativa de referência. No entanto, a densidade do solo é o parâmetro mais crítico, restringindo o crescimento das raízes e a captação de água e nutrientes. Quanto às árvores implantadas, observou-se um crescimento linear com a idade, tanto na CAP como na altura, apesar de se constatar certa estagnação na área A2 investigada, coincidente com os baixos valores de matéria orgânica e maior compactação no substrato. A área A1 (14 anos) é a que mais se aproxima da área de referência, tanto nos atributos edáficos como na fisionomia das plantas. A área A3 (8 anos) apresenta melhores características que a área A2 (11 anos), enquanto que a área A4 (6 anos), com bom crescimento, ainda reflete notadamente os efeitos da calagem e adubação.

Mediante a observação da cronosseqüência de revegetações comprova-se que a melhoria dos substratos acompanha o desenvolvimento da vegetação. Os efeitos adversos associados à compactação, aos baixos teores de matéria orgânica e ao crescimento de braquiária dificultam, em algumas situações, o desenvolvimento vegetal arbóreo.

Verificou-se que tanto os atributos físicos como os químicos selecionados se comportaram em maior ou menor grau como indicadores das mudanças que acontecem no substrato, refletindo a influência de cada um deles no crescimento das plantas. Conclui-se, portanto, que estes atributos são indicadores apropriados para avaliação da revegetação de áreas degradadas em recuperação no ambiente estudado.

A apreciação global do comportamento do substrato em conjunto com os resultados advindos das correlações estatísticas permitiram observar que a densidade do solo, o teor de matéria orgânica, o teor de fósforo e o pH são os parâmetros que refletem com mais propriedade as mudanças na vegetação, concluindo-se que são os indicadores principais para 
uma avaliação das condições ambientais, sendo os mais influentes no desenvolvimento das plantas. Ações de aperfeiçoamento do manejo devem ter como foco a melhoria destes indicadores principais.

A mineração selecionada para estudo de caso vem cumprindo com a tarefa de implantar a vegetação arbórea e garantir seu crescimento na bacia. Embora a composição florística seja diferenciada da mata natural do entorno, as áreas revegetadas já possuem uma comunidade vegetal bem estabelecida, com boa quantidade de espécies adaptadas às condições do substrato e que podem servir como exemplo bem-sucedido para a escolha de espécies em revegetações similares posteriores. A regeneração natural, tão esperada, já está ocorrendo, mas a presença de braquiária e a compactação do solo são os filtros mais atuantes que dificultam o estabelecimento espontâneo mais intenso de plântulas e da vegetação em geral, podendo incorrer em estagnação no crescimento dos indivíduos e retardar o processo sucessional da comunidade no futuro.

Um aspecto a ser examinado é o potencial de desenvolvimento posterior da vegetação já implantada e sua capacidade de auto-regeneração, isto é, a sustentabilidade no longo prazo. É recomendável buscar alternativas quanto à introdução de braquiária quando da implantação de vegetação e estimular o estabelecimento espontâneo de espécies herbáceas ou arbustivas nativas, desde que não tenham hábitos invasores, resultando em benefícios para o sistema em geral. Tais procedimentos devem favorecer também a diminuição da compactação dos locais revegetados nos estágios iniciais. Nas áreas atuais uma alternativa a ser testada é a implantação ou semeadura de espécies descompactadoras e/ou facilitadoras da regeneração natural, buscando-se avaliar sua adaptabilidade às condições locais. Outra possibilidade seria aproveitar a mata derrubada das áreas que irão ser mineradas, promovendo-se dessa forma o resgate de plântulas, epífitas, sementes ou qualquer outro tipo de propágulo para enriquecer as áreas revegetadas já estabelecidas, em conjunto com o controle da braquiária.

A aplicação do método, no estudo de caso, permitiu verificar as mudanças ocorridas nos substratos que acompanham o desenvolvimento das plantas, sendo que os indicadores numéricos da qualidade do substrato evidenciam, de forma quantitativa, a melhoria das condições ambientais vinculadas à revegetação.

O método proposto demonstra-se satisfatório para sua aplicação como instrumento de monitoramento. O acompanhamento do estado geral do substrato e a observação da vegetação acrescentam e enriquecem o julgamento das avaliações realizadas nas revegetações de áreas mineradas. Os procedimentos de amostragem e análise das propriedades físicas e químicas do substrato são eficazes para estabelecer um diagnóstico do seu estado geral, visando o 
acompanhamento da sua evolução. Desta forma, é possível verificar as melhorias decorrentes das atividades de manejo e seus efeitos quanto ao desenvolvimento da vegetação implantada. As análises estatísticas auxiliam na escolha dos parâmetros do substrato que, potencialmente, podem ser selecionados como indicadores de desempenho da revegetação.

O método é de fácil aplicação e não requer profissionais altamente especializados. Os procedimentos experimentados já são utilizados em agricultura, estando amplamente difundidos e padronizados. Há laboratórios de análises de solo em todo o território nacional a custos relativamente baixos.

Os resultados numéricos gerados balizam o método investigativo permitindo uma avaliação quantitativa e, conseqüentemente, mais clara e objetiva. Gestores ambientais públicos e privados de RAD podem incluir as rotinas do método para situações de monitoramento ambiental e acompanhamento dos resultados de programas de revegetação. Trata-se de uma ferramenta adicional e inovadora que introduz novos critérios e, tendo em vista seu caráter genérico, pode ser considerado um modelo de referência para obtenção de novos indicadores ambientais em minerações de areia ou outras de modalidades similares que pratiquem a revegetação para recuperar áreas mineradas. 


\section{REFERÊNCIAS}

AB'SÁBER, A. N. Ecossistemas do Brasil / Ecosystems of Brazil. São Paulo: Metalivros, 2009. 299 p.

ALMEIDA A. S. Engenharia da qualidade na mineração: modelo de controle estatístico de processo para brita e areia industrial. 2004. 270 p. Tese (Doutorado) - Escola Politécnica, Universidade de São Paulo, São Paulo, 2004.

ALMEIDA, R.O.P.O. Revegetação de áreas mineradas: estudo dos procedimentos aplicados em minerações de areia. São Paulo. 2002. 160 p. Dissertação (Mestrado) - Escola Politécnica, Universidade de São Paulo, São Paulo, 2002.

ALMEIDA, R.O.P.O.; SÁNCHEZ, L.E. Revegetação de áreas de mineração: critérios de monitoramento e avaliação de desempenho. Árvore, Viçosa, v.29, n.1 p.47-54, 2005.

ALMEIDA, R.O.P.O.; MUNIZ, M., CORDARO V.; RODRIGUES, R. R.; GANDOLFI. S.; NAVE, A. Expressão do banco de sementes alóctone (BSA) em duas condições de solo na Fazenda Intermontes (Capão Bonito, SP). Curitiba: SOBRADE, 2007. Trabalho apresentado na Reunião Técnica da SOBRADE "Indicadores na Recuperação de Áreas Degradadas", Curitiba, 10-11 nov. 2007. Não publicado.

ALUMINIUM COMPANY OF AMERICA - ALCOA. Australia - Bauxite mining. The mining and rehabilitation process. Disponível em:

<http:/www.alcoa.com/australia/en/info_page/mining_monitoring.asp >. Acesso em: 14 mar. 2009

ALVES, M. C.; SUZUKI, L. G. A. S.; SUZUKI, L. E. S. Densidade do solo e infiltração de água como indicadores de qualidade física de um Latossolo Vermelho distrófico em recuperação. Revista Brasileira de Ciencia do Solo, Viçosa, v. 31, n. 4, p. 617625, jul./ago. 2007.

ALVES, T. Estudo de Impacto Ambiental da Mineração Descalvado. São Paulo: T. Alves Engenharia Ambiental S/C Ltda. 1990. 3 volumes. V.1 RIMA, V.2 EIA, V3 Complementações EIA/RIMA.

ASSOCIAÇÃO BRASILEIRA DE NORMAS TÉCNICAS - ABNT. NBR 6457: Amostra de Solos- Preparação para ensaio de compactação e caracterização. Rio de Janeiro, 1986.

ASSOCIAÇÃO BRASILEIRA DE NORMAS TÉCNICAS - ABNT. NBR 6508: Solo Determinação da massa específica dos sólidos dos solos Rio de Janeiro, 1984.

ASSOCIAÇÃO BRASILEIRA DE NORMAS TÉCNICAS - ABNT. NBR 7181: SoloAnálise granulométrica por peneiramento. Rio de Janeiro, 1987. 
ASSOCIAÇÃO BRASILEIRA DE NORMAS TÉCNICAS - ABNT. NBR 9813: Solo Determinação da massa específica aparente "In situ" com emprego do cilindro de cravação. Rio de Janeiro, 1984.

BARBOSA, T. C.; COUTO H. T.; BARBOSA L. M.; PARAJARA, F. C.; BARBOSA, K. C. Proposta para a realização de amostragens e inventário de qualidade em reflorestamentos compensatórios do rodoanel do trecho sul. In: SIMPOSIO SOBRE RECUPERAÇÃO DE ÁREAS DEGRADADAS, 3., 2009, São Paulo. Anais. São Paulo: Instituto de Botânica, 2009. p. 45-49.

BERNARDI, A.; MACHADO, P.; FREITAS, P. L. Correção de solo e adubação no sistema de plantio direto nos cerrados. Rio de Janeiro: Embrapa, 2003. 22 p. (Embrapa Solos. Documentos. n. 46)

BENTO, M. A. B. Avaliação da qualidade dos substratos minerados em cinco cascalheiras revegetadas no Distrito Federal. 2009. 128 p. Dissertação (Mestrado) - Departamento de Engenharia Florestal, Universidade de Brasília. Faculdade de Tecnologia, Brasília, 2009.

BITAR, O. Avaliação da recuperação de áreas degradadas por mineração na Região metropolitana de São Paulo. 1997. 185 p. Tese (Doutorado) - Escola Politécnica, Universidade de São Paulo, São Paulo, 1997.

BRADY, N. C.; WEIL R. R. The nature and properties of soils. $13^{\text {th }}$ ed. Upper Saddle River, N.J: Pearson Prentice Hall, 2007. 980 p. Tradução do Depto. De Solos - ESALQ.

BRANCALION P. H. S.; GANDOLFI, S.; RODRIGUES, R. R. Indicadores de avaliação e monitoramento de áreas restauradas com reflorestamentos heterogêneos. In: SIMPÓSIO SOBRE RECUPERAÇÃO DE ÁREAS DEGRADADAS, 3., 2009, São Paulo. Anais. São Paulo: Instituto de Botânica, 2009. p. 106-114.

CAMPELLO, E.; FRANCO, A.; DIAS, L. Monitoramento ambiental. Ação Ambiental, Viçosa, n. 10, p. 22-25, 2000.

CARTER, M. R. Soil Quality for sustainable land management: organic matter and aggregation interactions that maintain soil functions. Agronomy Journal, v. 94, p. 38-47, 2002.

CARVALHO, J. L. N. Conversão do Cerrado para fins agrícolas na Amazônia e seus impactos no solo e no ambiente. 2006. 95 p. Dissertação (Mestrado) Escola Superior de Agricultura "Luiz De Queiroz", Universidade de São Paulo, Piracicaba, 2006.

CARVALHO, A. R. Atributos de solo associados às variações na vegetação em fragmentos de Cerrado, Assis, SP. 2008. 83 p. Dissertação (Mestrado) - Escola Superior de Agricultura "Luiz De Queiroz", Universidade de São Paulo, Piracicaba, 2008. 
CASAGRANDE, J. C.; SOARES, M.R. Técnicas para recuperação de solos visando ao reflorestamento em áreas degradadas. In: SIMPÓSIO SOBRE RECUPERAÇÃO DE ÁREAS DEGRADADAS, 3., 2009, São Paulo. Anais. São Paulo: Instituto de Botânica, 2009. p. 225-234.

CORRÊA, R. S. Recuperação de áreas degradadas pela mineração no cerrado: manual de revegetação. Brasília: Universa, 2005. 186 p.

CORRÊA, R. Reconstrução de solos minerados. Curitiba: SOBRADE, 2007. Curso ministrado durante a Reunião Técnica "Indicadores na Recuperação de Áreas Degradadas", Curitiba, 10-11 nov. 2007.

CORRÊA, R. S.; MELO FILHO, B. de; BAPTISTA, G. M. Avaliação fitossociológica da sucessão autogênica em áreas mineradas no Distrito Federal. Cerne, Lavras, v. 13, n.4, p. 406-415, out./dez. 2007.

CORREIA M.; ANDRADE, A. Formação de serrapilheira e ciclagem de nutrientes. In: SANTOS, G.; CAMARGO, F. (Ed.). Fundamentos da matéria orgânica no solo. Porto Alegre: Genesis, 1999. 491 p.

CUCHIERATO, G. Caracterização tecnológica de resíduos da mineração de agregados da região metropolitana de São Paulo (RMSP), visando seu aproveitamento econômico. 2000. 201 p. Dissertação (Mestrado)- Instituo de Geociências, Universidade de São Paulo, São Paulo, 2000.

DIAS, E. G. C. S. Avaliação do impacto ambiental de projetos de mineração no Estado de São Paulo: a etapa de acompanhamento. 2001. 283 p. Tese (Doutorado) - Escola Politécnica, Universidade de São Paulo, São Paulo, 2001.

DIAS, L. Caracterização de substratos para fins de recuperação de áreas degradadas. In: DIAS, L.; MELLO, J. (Ed.). Recuperação de áreas degradadas. Viçosa: Universidade Federal de Viçosa/ SOBRADE, 1998. p.27-44

DIAS, L.; ASSIS, I.; CAMPELLO, E.; FRANCO, A.; FARIA, S.; SOUSA JUNIOR, G.; SILVA, S. Crescimento de espécies vegetais em resposta a níveis de fertilidade visando a revegetação dos tanques de rejeito de bauxita da mineradora Rio do Norte. In: SIMPÓSIO BRASILEIRO DE RECUPERAÇÃO DE ÁREAS DEGRADADAS, 7., 2008, Curitiba. Anais: trabalhos voluntários. Curitiba: SOBRADE/ FUPEF, 2008. p. 597-598.

DIAS, L.; GRIFFITH, J. J. Conceituação e caracterização de áreas degradadas. In: DIAS, L.; MELLO, J. (Ed.). Recuperação de áreas degradadas. Viçosa: Universidade Federal de Viçosa/ SOBRADE, 1998. p. 1-7.

EMPRESA BRASILEIRA DE PESQUISA AGROPECUÁRIA - EMBRAPA. Monitoramento Ambiental em áreas sobre processo de reabilitação. Rio de Janeiro. Disponível em: <http://www.cnpab.embrapa.br/pesquisas/projetos $>$. Acesso em: 14 out. 2007. 
FERREIRA, G. C.; DAITX, E. C. A mineração de areia industrial na região sul de Brasil. REM: Revista da Escola de Minas, Ouro Preto, v. 56, n. 1, p. 59-65, jan./mar. 2003.

FONTES, M. Estudo pedológico reduz impactos da mineração. Ambiente, São Paulo, v. 5, n'1, p. 58-62, 1991.

FROUZ, J.; PIZL, V.; TAJOVSKY, K.; BALIK, V.; HANEL, L.; STARY, J.; LUKESOVA, A.; NOVAKOVA, A.; SOURKOVA, M.; PRIKRYL, I. Soil development and succession of soil biota in afforested and non-reclaimed sites in post mining landscape - preliminary results. In: INTERNATIONAL SYMPOSIUM ON ENVIROMENTAL ISSUES AND WASTE MANGEMENT IN ENERGY AND MINERAL PRODUCTION, $7^{\text {th }}$, 2002, Cagliari, Italy. Enviromental issues and waste management in energy and mineral production: proceedings SWEMP 2002. Cagliari: University of Cagliari, 2002. p. 621-626.

FYTAS, K. Mine reclamation issues in Canada. In: INTERNATIONAL SYMPOSIUM ON ENVIROMENTAL ISSUES AND WASTE MANGEMENT IN ENERGY AND MINERAL PRODUCTION, $8^{\text {th }}, 2004$, Kemer, Turkey. Environmental issues and waste management in energy and mineral production: proceedings. Ankara: Atilim University, 2004. p. 269-274.

GONÇALVES, J.L.M., NOGUEIRA JUNIOR, L.R.; DUCATTI, F. Recuperação de solos degradados. In: KAGEYAMA P.Y. (Org.) et al. Restauração ecológica de ecossistemas naturais. Botucatu: FEPAF, 2003. p. 111-163.

HARIDASAN, M. Recuperação e manejo de áreas de Cerrado. In: WORKSHOP RECUPERACAO E MANEJO DE AREAS DEGRADADAS NO CONTEXTO DA EMBRAPA E DO SNPA, 1997, Campinas. Memoria. Jaguariuna: EMBRAPACNPMA, 1998. $70 \mathrm{p}$.

INSTITUTO AGRONÔMICO DE CAMPINAS - IAC. Recomendações de adubação e calagem para o Estado de São Paulo. 2.ed.rev.atual. Campinas: Fundação IAC, 1997. 285 p. (Boletim técnico, 100).

INSTITUTO BRASILEIRO DO MEIO AMBIENTE E DOS RECURSOS NATURAIS RENOVÁVEIS - IBAMA. Manual de recuperação de áreas degradadas pela mineração. Brasília, 1990. 96 p.

IRIMIE, I.I. Operationalisation of the sustainable development concept, for a mining region, using community's capital notion and evaluating indicators. In: INTERNATIONAL SYMPOSIUM ON ENVIROMENTAL ISSUES AND WASTE MANGEMENT IN ENERGY AND MINERAL PRODUCTION, $7^{\text {th }}, 2002$, Cagliari, Italy. Enviromental issues and waste management in energy and mineral production: proceedings SWEMP 2002. Cagliari: University of Cagliari, 2002. p. 65-70.

KIEHL, E. J. Manual de edafologia: relações solo-planta. São Paulo: Agronômica Ceres, 1979. 263 p. 
KITAMURA, E.A.; ALVES, M.A.; SUZUKI, L.G.A.S; GONZALEZ, A. Recuperação de um solo degradado com a aplicação de adubos verdes e lodo de esgoto. Revista . Brasileira de Ciencia do Solo, Viçosa, v. 32, n. 1, p. 405-416, jan./fev. 2008

KLEIN, V. Densidade relativa: um indicador da qualidade física de um latossolo vermelho. Revista de Ciências Agroveterinárias, Lages, v. 5, n. 1 p. 26-32, 2006.

KNAPIK, P; MARANHO, L. T. Avaliação da revegetação em área de mineração, região de inundação do rio Iguaçu, Araucária, PR. Revista Brasileira de Biociências. V. 5, supl. 1, p. 507-509. jul. 2007. Nota científica.

LARSON, W. E.; PIERCE F. J. Quantifying indicators for soil quality. In: DORAN, J.W. et al. (Ed.). Defining soil quality and sustainable environment: proceedings. Madison: American Society of Agronomy, 1994. p. 323-349. (Soil Science Society of America Special Publication, 35).

LETEY, J. Relationship between soil physical properties and crop production. In. Advances in soil science. New York: Springer-Verlag, 1985. p. 277-294.

LIMA, C.; PILLON, C.; LIMA, A.; SANTOS, D.; GONÇALVES, L.; SILVA, A. Qualidade física de um argissolo sob sistema de plantio direto de milho e mamona. In: SIMPÓSIO BRASILEIRO DE RECUPERAÇÃO DE ÁREAS DEGRADADAS, 7., 2008, Curitiba. Anais: trabalhos voluntários. Curitiba: SOBRADE/ FUPEF, 2008. p. 533- 534.

LU, D.; MORAN, E.; MAUSEL, P. Linking amazonian secondary succession forest growth to soil properties. Land Degradation and Development, Chichester; v. 13, p. 331-343, 2002.

MACHADO, P. L. O. de A. Compactação de solo e crescimento de plantas: como identificar, evitar e remediar. Rio de Janeiro: Embrapa, 2003. 18 p. (Embrapa Solos. Documentos, $\left.n^{\circ} 56\right)$.

MAGALHÃES JUNIOR, A. P. Indicadores ambientais e recursos hídricos: realidade e perspectivas para o Brasil. São Paulo: Bertrand Brasil Editora, 2007. 688 p.

MANOLIADIS, O. G. Development of ecological indicators - a methodological framework using compromise programming. Ecological Indicators, Amsterdam, v.2, n. 1-2, p. 169-176, Nov. 2002.

Referencias a rever ainda:

MELO W. Caracterização física e química de áreas mineradas pela extração de cassiterita. Depto. de Tecnologia FCAV/UNESP. Jaboticabal, SP. Disponível em: < http://www.monografias.com >. Acesso em: 21 de novembro de 2007.

MISAK R. F.; AL-AWADHI; OMAR S.A.; SHAHID S.A. Soil Degradationin Kabd area, southwestern Kuwait city. Land Degradation \& Development. 13: 403-415 (2002).

MINERAÇÃO DESCALVADO. Plano de recuperação de áreas degradadas. Revisão 01. Descalvado: Engenharia, Consultoria e Planejamento Ambiental, 1997. 
MINISTERIO DE MEDIO AMBIENTE - MMA. Indicadores ambientales. Una propuesta para España. Madrid: Dirección General de Calidad y Evaluación Ambiental 1996. 140p.

MÖLLERHERM, S.; MARTENS P. N. Development of sustentability indicators for the mineral industries. In: $8^{\text {th }}$ International Symposium on Enviromental Issues and Waste Mangement in Energy and Mineral Production - SWEMP, Kemer/Antalia, Turkey, May 17-20, 2004. Enviromental Issues and Waste Mangement in Energy and Mineral Production. Turkey: Atilim University, 2004. pp.17-23.

NAVE, A.G. Produção de mudas: aspectos legais e operacionais. In: BARBOSA, L.M. (coord.). Anais do III Simpósio sobre recuperação de áreas degradadas. São Paulo: Instituto de Botânica, 2009. p. 181-185

NAVE, A. G. Banco de sementes autóctone e alóctone, resgate de plantas e plantio de vegetação nativa na fazenda Intermontes, Município de Riberào Grande, SP. 2003. 218 p. Tese (Doutorado) - ESALQ-USP. Piracicaba, 2003.

NAPPO, M. E.; OLIVEIRA FILHO, A.T.; MARTINS, S. V. A estrutura do sub-bosque de povoamentos homogêneos de Mimosa scabrella Bentham, em área minerada, em Poços de Caldas, MG. Ciência Florestal, Santa Maria. V.10, n. 2, p. 17-29

OLIVEIRA, J. B. Solos do Estado de São Paulo: descrição de classes registradas no mapa pedológico. Campinas: IAC, 1999. 112 p. (Boletim Científico, 45).

OLIVEIRA, L. B.; DA LUZ L. R.; DELAIA, M. P. Contribuição aos estudos de compactação, adensamento e coesão do solo. Rio de Janeiro: Embrapa Solos, 2002. 221 p. (Embrapa Solos. Documentos, $\left.n^{\circ} 44\right)$.

PA BRASIL. Estudo de Impacto Ambiental da Mineração Descalvado Ltda. São Paulo: PA Brasil Consultoria, Planejamento e Gestão Ambiental Ltda. 2008. 4 volumes. V.1-2 EIA texto, V.3 EIA Anexo, V.4 RIMA, V.5 RIMA Anexo.

PARROTA, J.A.; KNOWLES, O. H. Restoring tropical forest on lands mined for bauxite: examples from the brazilian amazon. Ecological Engineering, v.17 pp. 219-239, 2001. Elsevier Science.

PIERZYNSKI, G. M.; SIMS, J.T.; VANCE, G.F. Soils and environmental quality. Boca Raton, Florida: Lewis Publishers, 1994. 313 p.

PRIMAVESI, A. O manejo ecológico do solo: agricultura em regiões tropicais.

São Paulo: Nobel, 1981. 541 p.

PRIMAVESI, A. A compactação de solos agrícolas. Informações Agronômicas, Campinas. V. 29 p. 1-4, 1985. 
RAIJ, V. V; ANDRADE, J.; CANTARELLA, H.; QUAGGIO, J. Análise Química para avaliação da fertilidade de solos tropicais. Campinas: Instituto Agronômico de Campinas, 2001. 285 p.

RÉ, T. M. O uso de formigas como bioindicadores no monitoramento ambiental de revegetação de áreas mineradas 2007, 244 p. Tese (Doutorado) - Escola Politécnica, Universidade de São Paulo, São Paulo.

REIS DUARTE, R. M.; CASAGRANDE, J. C. A interação solo-planta na recuperação de áreas degradadas In: BARBOSA, L.M. (coord.). Manual para recuperação de áreas degradadas do estado de São Paulo: Matas Ciliares do Interior Paulista. São Paulo: Instituto de Botânica, 2006. p. 52-69.

REIS, L. Monitoramento da recuperação ambiental de áreas de mineração de bauxita na Floresta Nacional de Saracá Porto Trombetas (PA). Tese (doutorado). UFRJ, Instituto de Agronomia, 2006. 159 p.

REINERT, D. Recuperação de solos em sistemas agropastoris. In: DIAS, L.; MELLO, J. (Ed.) Recuperação de áreas degradadas. Viçosa: Universidade Federal de Viçosa/ SOBRADE, 1998. pp. 163-176.

RODRIGUES, R. R.; GANDOLFI S. Conceitos, tendências e ações para recuperação de florestas ciliares. In: RODRIGUES, R. R.; LEITÃO FILHO, H. (Eds.) Matas ciliares: conservação e recuperação. São Paulo: Edusp-Fapesp, 2000.

RODRIGUES, R. R. Análise estrutural das formações florestais ripárias. In:

BARBOSA, L.M. (Coord.). Simpósio sobre Matas Ciliares. Mogi-Guaçú, São Paulo, 1989. 99-116

RUGGIERO, G. P.; PIVELLO V. R. As relações entre a vegetação e o meio físico no Cerrado Pé-de-gigante. O solo e a comunidade vegetal. In: Pivello, V. R; Varanda M.E. O Cerrado Pé-do-gigante, Parque Estadual de Vassununga. Ecologia e conservação. São Paulo: SMA, 2005. PP. 174-188.

RUIZ-JAEN M.C.; AIDE T. M. Restoration succes: how is it measured?. Restauration Ecology. v.13 , $\mathrm{n}^{\circ}$ 3, pp. 569-577, 2005. Society for Ecological Restauration International.

SALOMÃO, R.P. et al. Uso de parcelas permanentes em reflorestamentos de diversas idades para a avaliação da recuperação de áreas mineradas, Porto Trombetas, Oriximiná, Pará. In: Simpósio Brasileiro de Recuperação de Áreas Degradadas, III. 1997. Ouro Preto, MG. Trabalhos Voluntários. Viçosa, MG. SOBRADE, UFV, 1997. pp. 324-328.

SÁNCHEZ, L.E. Conceitos. In: Recuperação de áreas degradadas. Curso de especialização em gestão e tecnologias ambientais. Universidade de São Paulo, 2005. 
SENTELHAS, P.C.; PEREIRA, A.R.; MARIN, F.R.; ANGELOCCI, L.R.; ALFONSI, R.R.; CARAMORI, P.H.; SWART, S. Balanços Hídricos Climatológicos do Brasil 500 balanços hídricos de localidades brasileiras. Piracicaba: ESALQ, 1999. 1 CD-ROM.

SAUTTER, K. Indicadores biológicos na recuperação de solos degradados. Palestra ministrada na Reunião Técnica Indicadores na Recuperação de Áreas

Degradadas. SOBRADE Curitiba. 10 e 11 de novembro, 2007.

SILVA Jr. DA, M. C.; DE BARROS, N. F.; CÂNDIDO, J. F. Relações entre parâmetros de solo e de vegetação de cerrado na Estação Florestal de Experimentação de Paraopeba - MG. Revta. Brasil. Bot., v. 10, p. 125-137, 1987.

SECRETARIA DE MEIO AMBIENTE - SMA. Resolução SMA-42 de 16/09/96. Licenciamento Ambiental dos Empreendimentos de Extração de Areia na Bacia Hidrográfica do Rio Paraíba do Sul. São Paulo: Secretaria de Meio Ambiente, 1996.

SECRETARIA DE MEIO AMBIENTE - SMA. Resolução SMA-21 de 21/11/01. Fixa orientação para o reflorestamento heterogêneo de áreas degradadas e dá providencias. São Paulo: Secretaria de Meio Ambiente, 2001.

SECRETARIA DE MEIO AMBIENTE - SMA. Resolução SMA-47 de 29/11/03. Fixa orientação para o reflorestamento heterogêneo de áreas degradadas e dá providencias. São Paulo: Secretaria de Meio Ambiente, 2003.

SECRETARIA DE MEIO AMBIENTE - SMA. Resolução SMA-8 de 31/01/08. Fixa a orientação para o reflorestamento de áreas degradadas e dá providências correlatas. São Paulo: Secretaria de Meio Ambiente, 2008.

SOCIETY FOR ECOLOGICAL RESTAURATION - SER. The SER International Primer on Ecological Restauration. Society for Ecological Restauration Science \& Policy Working Group. 2004. Disponível em: http//www.ser.org. Acessado em outubro de 2007. Society for Ecological Restauration International. Tucson Arizona.

SEYBOLD, C.A.; HERRICK, J.E.; BREJDA, J.J. Soil resilience: a fundamental component of soil quality. Soil science. 164(4): 224-234. 1999.

SINGH, M. P.; MATHO, M. Ecological principles in restoration of derelict mined ecosystems. In: Geonviromental Reclamation International Symposium, India, 2000. Geoenviromental Reclamation International Symposium. Balkema Roterdam Netherlands: Shree R.K.N. Engg. College, 2000. pp.49-54.

SOUZA, M.G. Revegetação de taludes com geotêxtil em área minerada. Viçosa: UFV, 1997. 47p.

TANAKA, N. I., CHU, B. C., YASSUNAGA, Y. Relatório de Análise Estatística sobre o Projeto: "Indicadores de Qualidade do Solo para Monitoramento de Áreas Revegetadas. Estudo Dirigido à Mineração de Areia". São Paulo, IMEUSP, 2009. RAE - CEA - 09P22. 
TANNO, L. C.; SINTONI, A. (Coord.). Mineração e município: bases para o planejamento e gestão dos recursos minerais. São Paulo: Instituto de Pesquisas Tecnológicas, 2003. 177 p. (Publicação IPT, 2850).

TEIXEIRA, P.; RIBEIRO, G.; RODRIGUES, M. Caracterização química de alguns solos da bacia petrolífera de Urucu, estado de Amazonas. In: Simpósio Brasileiro de Recuperação de Áreas Degradadas, VII. 9-11 de outubro, 2008. Curitiba, Paraná. Anais. Trabalhos Voluntários. Curitiba: SOBRADE, FUPEP, 2008.

TOKGÖZ, N. The effect of the tree roots on the forested land over the surface coal mine residual materials; rehabilitation and stabilitation of the land. In: $8^{\text {th }}$ International Symposium on Enviromental Issues and Waste Mangement in Energy and Mineral Production - SWEMP, Kemer/Antalia, Turkey, May 17-20, 2004. Enviromental Issues and Waste Management in Energy and Mineral Production. Turkey: Atilim University, 2004. pp.305-311.

TROEH, F.; THOMPSON, L. M. Solos e fertilidade do solo. $6^{a}$ edição, São Paulo: Andrei Editora. 2007. 718 p.

VALCARCEL R. Indicadores de RAD. Fundamentos teóricos, aplicações e entraves. Curitiba: SOBRADE, 2007. Curso ministrado durante a Reunião Técnica "Indicadores na Recuperação de Áreas Degradadas", Curitiba, 10-11 nov. 2007.

VARELA M. E.; DE BLAS E.: BENITO E. Physical Soil degradation induced by deforestation and slope modification in a temperate-humid enviroment. Land degradation and development. 12: 477-484. 2001.

VARGAS, M. Introdução à mecânica de solos. São Paulo: MCgraw-Hill do Brasil, Edusp, 1977. 509 p.

WHITAKER, W. Técnicas de preparação de areia para uso na construção civil. 2001, 202 p. Tese (Mestrado) - Escola Politécnica Universidade de São Paulo, São Paulo.

ZUEN-SANG CHEN Selecting indicators to evaluate soil quality. Departament of Agricultural Chemistry. National Taiwan University. Disponível em: $<$ http://www.agnet.org/library/eb/473> Acesso em: 2 de novembro de 2008. 


\section{REFERÊNCIAS COMPLEMENTARES}

LORENZI, H. Árvores Brasileiras. Manual de identificação e cultivo de plantas arbóreas nativas do Brasil, vol. 1. 5. ed. Nova Odessa: Instituto Plantarum. 2008. $384 \mathrm{p}$.

LORENZI, H. Árvores Brasileiras. Manual de identificação e cultivo de plantas arbóreas nativas do Brasil, vol. 2. 2. ed. Nova Odessa: Instituto Plantarum. 2002. 368 p.

RAMOS, V. S.; DURIGAN G.; FRANCO, G. A. D. C.; SIQUEIRA, M. F. RODRIGUES, R. R. Árvores da Floresta Estacional Semidecidual. Guia de identificação de espécies. São Paulo: Editora da Universidade de São Paulo., Biota, FAPESP. 2008. 320 p. 
APÊNDICE A: ÉSPECIES VEGETAIS ARBÓREAS NAS ÁREAS DE ESTUDO 
Tabela A1: Espécies vegetais arbóreas identificadas na área A1.

\begin{tabular}{|c|c|c|c|}
\hline \multicolumn{3}{|c|}{ Área A1 (14 anos) } & \multirow[b]{2}{*}{$\mathrm{CS}^{*}$} \\
\hline & Nome comum & Nome científico & \\
\hline 1 & Açoita cavalo & Luehea paniculata & NP \\
\hline 2 & Amendoim & Pterogyne nitens & NP \\
\hline 3 & Angico & Anadenanthera peregrina & NP \\
\hline 4 & Angico vermelho & Anadenanthera macrocarpa & NP \\
\hline 5 & Aroeira pimenteira & Schinus terebentifolius & $\mathrm{P}$ \\
\hline 6 & Cambará & Gochnatia polyforma & $\mathrm{P}$ \\
\hline 7 & Canafístula & Peltophorum dubium & $\mathrm{P}$ \\
\hline 8 & Capixingui & Croton floribundus & $\mathrm{P}$ \\
\hline 9 & Caroba & Jacaranda micrantha & $\mathrm{P}$ \\
\hline 10 & Cedro & Cedrela fisilis & $\mathrm{P}$ \\
\hline 11 & Dedaleiro & Lafoensia pacari & NP \\
\hline 12 & Faveiro & Dimorphandra mollis & NP \\
\hline 13 & Goiabeira & Psidium guajaba & $\mathrm{P}$ \\
\hline 14 & Ingá & Inga edulis & NP \\
\hline 15 & Inga banana & Inga uruguensis & $\mathrm{P}$ \\
\hline 16 & Ipê amarelo & Tabebuia cassinoides & NP \\
\hline 17 & Jacarandá do cerrado & Machaerum acutifolium & $\mathrm{NP}$ \\
\hline 18 & Jacarandá mimoso & Jacaranda mimosaefolia & \\
\hline 19 & Jambolão & Sysiguim jambos & Exotica \\
\hline 20 & Jatobá & Hymenaea stiginocarpa & NP \\
\hline 21 & Manguba & Pseudobombax munguba & NP \\
\hline 22 & Monjoleiro & Acacia polyphilla & $\mathrm{P}$ \\
\hline 23 & Paineira & Chorisia speciosa & NP \\
\hline 24 & Pau ferro & Connarus cf. suberosus & NP \\
\hline 25 & Pitanga & Eugenia costata & NP \\
\hline 26 & Roseirinha & Maprounea guianensis & NP \\
\hline 27 & Soiná & Erythrina speciosa & NP \\
\hline 28 & Jambo & Sizygium cumini & \\
\hline 29 & Unha de boi & Bauhinia forficata & $P$ \\
\hline 30 & Não identificado & Euphorbiaceae (Família) & \\
\hline 31 & Não ident.,sem folha & - & \\
\hline 32 & Espinhadeira & Sebastiana commersoniana & NP \\
\hline
\end{tabular}

* CS: Classe sucessional P: Pioneiras; NP: Não pioneiras 
Tabela A2: Espécies vegetais arbóreas identificadas na área A2.

\begin{tabular}{|c|c|c|c|}
\hline \multicolumn{4}{|c|}{ Área A2 (11 anos) } \\
\hline & Nome comum & Nome científico & $\mathrm{CS}$ \\
\hline 1 & Açoita cavalo & Luehea paniculata & $\mathrm{NP}$ \\
\hline 2 & Alecrim-do-campo & Baccaris dracunculifolia & $\mathrm{P}$ \\
\hline 3 & Angico vermelho & Anadenanthera macrocarpa & NP \\
\hline 4 & Angico & Adenanthera peregrina & $\mathrm{NP}$ \\
\hline 5 & Araçá & Psidium cattleanum & $\mathrm{NP}$ \\
\hline 6 & Aroeira pimenteira & Schinus terebentifolius & $\mathrm{P}$ \\
\hline 7 & Assa-peixe & Vernonia polyanthes & $P$ \\
\hline 8 & Cambará & Gochnatia polymorpha & $\mathrm{P}$ \\
\hline 9 & Canafístula & Peltophorum dubium & $\mathrm{P}$ \\
\hline 10 & Canjarana & Cabralea canjerana & $\mathrm{NP}$ \\
\hline 11 & Capixingui & Croton floribundus & $\mathrm{P}$ \\
\hline 12 & Caroba & Jacaranda micrantha & $\mathrm{P}$ \\
\hline 13 & Dedaleiro & Lafoensia pacari & $\mathrm{NP}$ \\
\hline 14 & Goiabeira & Psidium guajaba & $\mathrm{P}$ \\
\hline 15 & Inga banana & Inga uruguensis & $\mathrm{P}$ \\
\hline 16 & Ingá & Inga edulis & $\mathrm{NP}$ \\
\hline 17 & Ipê amarelo & Tabebuia cassineoides & $\mathrm{NP}$ \\
\hline 18 & Jambo & Sizygium cumini & Exótica \\
\hline 19 & Jambolão & Sizygium jambos & Exótica \\
\hline 20 & Jatobá & Hymenaea stigonocarpa & $\mathrm{NP}$ \\
\hline 21 & Manguba & Pseudobombax munguba & $\mathrm{NP}$ \\
\hline 22 & Monjoleiro & Acacia polyphilla & $\mathrm{P}$ \\
\hline 23 & Canela & Ocotea pulchella & $\mathrm{NP}$ \\
\hline 24 & Peroba rosa & Aspidosperma sp. & NP \\
\hline 25 & Sansão-do-campo & Mimosa caesalpineafolia & \\
\hline 26 & Soiná & Erythrina speciosa & $\mathrm{NP}$ \\
\hline 27 & Timburi & Enterolobium contortisiliqum & $\mathrm{P}$ \\
\hline 28 & Carobinha & Jacaranda puberula & $\mathrm{NP}$ \\
\hline 29 & Espinhadeira & Sebastiana commersoniana & $\mathrm{NP}$ \\
\hline 30 & Guaiuvira & Cordia americana & $\mathrm{P}$ \\
\hline 31 & Canela de ema & Não identificado & \\
\hline
\end{tabular}

* CS: Classe sucessional P: Pioneiras; NP: Não pioneiras 
Tabela A3: Espécies vegetais arbóreas identificadas na área A3.

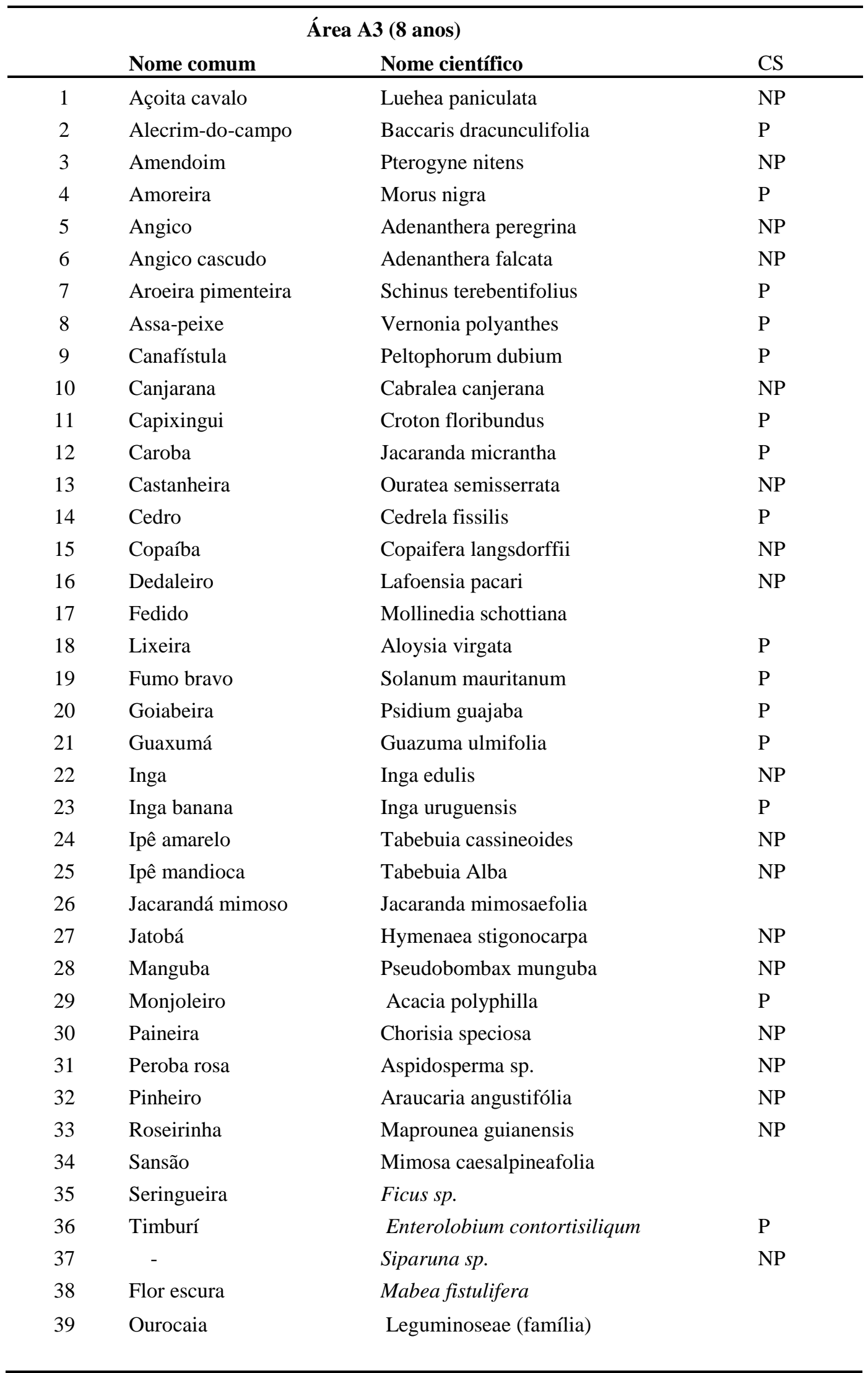


* CS: Classe sucessional P: Pioneiras; NP: Não pioneiras

Tabela A4: Espécies vegetais arbóreas identificadas na área A4.

\begin{tabular}{|c|c|c|c|}
\hline \multicolumn{3}{|c|}{ Área A4 (6 anos) } & \multirow[b]{2}{*}{$\mathrm{CS}$} \\
\hline & Nome comum & Nome científico & \\
\hline 1 & Fumo bravo & Solanum mauritanum & $\mathrm{P}$ \\
\hline 2 & Açoita cavalo & Luehea paniculata & $\mathrm{NP}$ \\
\hline 3 & Amendoim & Pterogyne nitens & $\mathrm{NP}$ \\
\hline 4 & Aroeira pimenteira & Schinus terebentifolius & $\mathrm{P}$ \\
\hline 5 & Bambu chinés & Bambusa mitis & Exótica \\
\hline 6 & Canafístula & Peltophorum dubium & $\mathrm{P}$ \\
\hline 7 & Caroba & Jacaranda micrantha & $\mathrm{P}$ \\
\hline 8 & Dedaleiro & Lafoensia pacari & NP \\
\hline 9 & Goiabeira & Psidium guajaba & $\mathrm{P}$ \\
\hline 10 & Ingá & Inga edulis & NP \\
\hline 11 & Inga banana & Inga uruguensis & $\mathrm{P}$ \\
\hline 12 & Ipê amarelo & Tabebuia cassineoides & NP \\
\hline 13 & Mamica de cadela & Brosimum gaudichaudii & $\mathrm{NP}$ \\
\hline 14 & Manguba & Pseudobombax munguba & $\mathrm{NP}$ \\
\hline 15 & Monjoleiro & Acacia polyphilla & $\mathrm{P}$ \\
\hline 16 & Paineira & Chorisia speciosa & $\mathrm{NP}$ \\
\hline 17 & Peito de pomba & Tapirira guianensis & NP \\
\hline 18 & Peroba rosa & Aspidosperma sp. & $\mathrm{NP}$ \\
\hline 19 & Pindaiba de macaco & Xylopia aromatica & $\mathrm{P}$ \\
\hline 20 & Pitanga & Eugenia costata & $\mathrm{NP}$ \\
\hline 21 & Sansão & Mimosa caesalpineafolia & \\
\hline 22 & Timburi & Enterolobium contortisiliqum & $\mathrm{P}$ \\
\hline 23 & Ourocaia & Leguminoseae (família) & \\
\hline
\end{tabular}

* CS: Classe sucessional P: Pioneiras; NP: Não pioneiras 
Tabela A5: Espécies vegetais arbóreas identificadas na área A5.

\begin{tabular}{|c|c|c|c|}
\hline \multicolumn{4}{|c|}{ Área A5 (Mata Nativa) } \\
\hline & Nome comum & Nome científico & $\mathrm{CS}$ \\
\hline 1 & Angico vermelho & Anadenanthera macrocarpa & NP \\
\hline 2 & Cambui & Myrcia multiflora & NP \\
\hline 3 & Canela & Ocotea pulchella & NP \\
\hline 4 & Canelão & Nectandra cuspidata & NP \\
\hline 5 & Canelinha & Nectandra megapotamica & NP \\
\hline 6 & Copaíba & Copaifera langsdorffii & NP \\
\hline 7 & (folha larga) & Terminalia sp. & $P$ \\
\hline 8 & (folha miúda) & Leguminoseae (família) & \\
\hline 9 & (desmancha tronco) & Calyptranthes clusifolia & \\
\hline 10 & Faveiro & Dimorphandra mollis & NP \\
\hline 11 & Fedido & Mollinedia schottiana & \\
\hline 12 & Ipé roxo & Tabebuia heptaphylla & NP \\
\hline 13 & Jacarandá do cerrado & Machaerum acutifolium & NP \\
\hline 14 & Parece abacateiro & Ocotea sp. & NP \\
\hline 15 & (parece araçá) & Psidium mirtoides & \\
\hline 16 & (parece j. mimoso) & Leguminoseae (família) & \\
\hline 17 & Peito de pomba & Tapirira guianensis & $\mathrm{P}$ \\
\hline 18 & Pimentinha & Erythroxylum amplifolium & NP \\
\hline 19 & Pindaíba de macaco & Xylopia aromatica & $\mathrm{P}$ \\
\hline 20 & Pororoca & Rapanea umbellata & NP \\
\hline 21 & Quaresmeira do campo & Tibouchina sp. & $\mathrm{P}$ \\
\hline 22 & Quaresmeira do mato & Tibouchina sp. & $\mathrm{P}$ \\
\hline 23 & Roseirinha & Maprocinea guianensis & NP \\
\hline 24 & (tronco de angico) & Anadenanthera sp. & NP \\
\hline 25 & $\mathrm{x} 1$ & Myrcia splendans & \\
\hline 26 & $\mathrm{x} 2$ & Amaioue guianensis & \\
\hline 27 & $\mathrm{x} 3$ & Siparuna guianensis & NP \\
\hline 28 & $\mathrm{x} 4$ & Byrsonima sp. & $\mathrm{P}$ \\
\hline 29 & $\mathrm{x} 5$ & Myrtaceae (família) & \\
\hline 30 & $\mathrm{x} 6$ & Myrtaceae (família) & \\
\hline 31 & $\mathrm{x} 7$ & Eugenia sp. & NP \\
\hline 32 & $\mathrm{x} 8$ & Vochysia sp & \\
\hline 33 & x9 & Mircynaceae (família) & \\
\hline 33 & Pele de lagarto & Não identificado & \\
\hline
\end{tabular}

* CS: Classe sucessional P: Pioneiras; NP: Não pioneiras 


\section{APÊNDICE B: MEDIDAS RESUMO DAS VARIÁVEIS DO SUBSTRATO}


Tabela C.1.1: Densidade na área A1

\begin{tabular}{ccccccc}
\hline \multicolumn{7}{c}{ Densidade $\left(\mathrm{g} / \mathrm{cm}^{3}\right)$} \\
\hline & Média & DP & CV & Mínimo & Mediana & Máximo \\
\cline { 2 - 7 } Profundidade $(\mathrm{cm})$ & 1.42 & 0.02 & 1.72 & 1.40 & 1.42 & 1.44 \\
$0-20$ & 1.49 & 0.04 & 2.98 & 1.44 & 1.49 & 1.53 \\
$20-40$ & 1.50 & 0.02 & 1.07 & 1.48 & 1.50 & 1.51 \\
$40-60$ & 1.45 & 0.01 & 0.75 & 1.44 & 1.45 & 1.46 \\
$60-80$ & 1.48 & 0.01 & 1.01 & 1.47 & 1.48 & 1.50 \\
$80-100$ & & & & & & \\
\hline
\end{tabular}

Tabela C.1.2: Densidade na área A2

\begin{tabular}{|c|c|c|c|c|c|c|}
\hline \multicolumn{7}{|c|}{ Densidade $\left(\mathrm{g} / \mathrm{cm}^{3}\right)$} \\
\hline \multirow[b]{2}{*}{ Profundidade $(\mathrm{cm})$} & \multicolumn{6}{|c|}{ A2 (11 anos) } \\
\hline & Média & DP & $\mathrm{CV}$ & Mínimo & Mediana & Máximo \\
\hline $0-20$ & 1.55 & 0.10 & 6.18 & 1.47 & 1.52 & 1.66 \\
\hline $20-40$ & 1.62 & 0.08 & 4.69 & 1.55 & 1.61 & 1.70 \\
\hline $40-60$ & 1.63 & 0.04 & 2.62 & 1.58 & 1.65 & 1.66 \\
\hline $60-80$ & 1.75 & 0.08 & 4.82 & 1.69 & 1.71 & 1.84 \\
\hline $80-100$ & 1.79 & 0.16 & 8.95 & 1.69 & 1.70 & 1.97 \\
\hline
\end{tabular}

Tabela C.1.3: Densidade na área A3

\begin{tabular}{ccccccc}
\hline \multicolumn{7}{c}{ Densidade $\left(\mathrm{g} / \mathrm{cm}^{3}\right)$} \\
\hline & Média & DP & CV & Mínimo & Mediana & Máximo \\
\cline { 2 - 7 } Profundidade $(\mathrm{cm})$ & 1.42 & 0.02 & 1.51 & 1.40 & 1.42 & 1.44 \\
\hline $0-20$ & 1.43 & 0.11 & 7.53 & 1.31 & 1.46 & 1.53 \\
$20-40$ & 1.56 & 0.13 & 8.35 & 1.48 & 1.50 & 1.71 \\
$40-60$ & 1.58 & 0.11 & 6.79 & 1.47 & 1.59 & 1.68 \\
$60-80$ & 1.75 & 0.07 & 3.78 & 1.71 & 1.72 & 1.83 \\
$80-100$ & & & & & & \\
\hline
\end{tabular}

Tabela C.1.4: Densidade na área A4

\begin{tabular}{ccccccc}
\hline \multicolumn{7}{c}{ Densidade $\left(\mathrm{g} / \mathrm{cm}^{3}\right)$} \\
\hline & \multicolumn{7}{c}{ A4 (6 anos) } \\
\cline { 2 - 7 } Profundidade $(\mathrm{cm})$ & Média & DP & CV & Mínimo & Mediana & Máximo \\
\hline $0-20$ & 1.47 & 0.09 & 6.37 & 1.37 & 1.53 & 1.53 \\
$20-40$ & 1.70 & 0.10 & 5.87 & 1.59 & 1.72 & 1.79 \\
$40-60$ & 1.67 & 0.08 & 4.65 & 1.60 & 1.65 & 1.75 \\
$60-80$ & 1.71 & 0.10 & 6.01 & 1.64 & 1.67 & 1.83 \\
$80-100$ & 1.71 & 0.06 & 3.31 & 1.68 & 1.69 & 1.78 \\
\hline
\end{tabular}

Tabela C.1.5: Densidade na área A5

\begin{tabular}{ccccccc}
\hline \multicolumn{7}{c}{ Densidade $\left(\mathrm{g} / \mathrm{cm}^{3}\right)$} \\
\hline & \multicolumn{7}{c}{ A5 (mata nativa) } \\
\cline { 2 - 7 } Profundidade $(\mathrm{cm})$ & Média & DP & CV & Mínimo & Mediana & Máximo \\
\hline $0-20$ & 1.14 & 0.10 & 8.49 & 1.06 & 1.10 & 1.25 \\
$20-40$ & 1.44 & 0.00 & 0.31 & 1.44 & 1.44 & 1.45 \\
$40-60$ & 1.44 & 0.01 & 0.64 & 1.43 & 1.44 & 1.45 \\
$60-80$ & 1.44 & 0.02 & 1.15 & 1.42 & 1.45 & 1.46 \\
$80-100$ & 1.44 & 0.02 & 1.07 & 1.42 & 1.45 & 1.45 \\
\hline
\end{tabular}


Tabela C.2.1: Porosidade na área A1

\begin{tabular}{ccccccc}
\hline & \multicolumn{7}{c}{ Porosidade (\%) } \\
\hline & \multicolumn{7}{c}{ A1 (14 anos) } \\
\cline { 2 - 7 } Profundidade (cm) & Média & DP & CV & Mínimo & Mediana & Máximo \\
\hline $0-20$ & 44.18 & 1.03 & 2.32 & 43.15 & 44.20 & 45.20 \\
$20-40$ & 41.51 & 2.36 & 5.69 & 38.85 & 42.37 & 43.32 \\
$40-60$ & 41.03 & 2.37 & 5.78 & 39.47 & 39.85 & 43.76 \\
$60-80$ & 42.89 & 1.38 & 3.22 & 41.87 & 42.34 & 44.47 \\
$80-100$ & 41.75 & 2.00 & 4.79 & 40.07 & 41.22 & 43.97 \\
\hline
\end{tabular}

Tabela C.2.2: Porosidade na área A2

\begin{tabular}{ccccccc}
\hline \multicolumn{7}{c}{ Porosidade $(\%)$} \\
\hline & \multicolumn{7}{c}{ A2 (11 anos) } \\
\cline { 2 - 7 } Profundidade $(\mathrm{cm})$ & Média & DP & CV & Mínimo & Mediana & Máximo \\
\hline $0-20$ & 41.15 & 3.64 & 8.85 & 37.10 & 42.21 & 44.14 \\
$20-40$ & 38.47 & 2.89 & 7.51 & 35.34 & 39.03 & 41.03 \\
$40-60$ & 38.04 & 1.63 & 4.27 & 36.90 & 37.32 & 39.90 \\
$60-80$ & 33.68 & 3.20 & 9.50 & 30.04 & 34.98 & 36.02 \\
$80-100$ & 32.14 & 6.08 & 18.92 & 25.12 & 35.49 & 35.79 \\
\hline
\end{tabular}

Tabela C.2.3: Porosidade na área A3

\begin{tabular}{ccccccc}
\hline \multicolumn{7}{c}{ Porosidade (\%) } \\
\hline & \multicolumn{7}{c}{ A3 (8 anos) } \\
\cline { 2 - 7 } Profundidade $(\mathrm{cm})$ & Média & DP & CV & Mínimo & Mediana & Máximo \\
\hline $0-20$ & 46.01 & 0.82 & 1.78 & 45.24 & 45.93 & 46.87 \\
$20-40$ & 45.64 & 4.10 & 8.98 & 42.06 & 44.76 & 50.10 \\
$40-60$ & 40.62 & 4.96 & 12.21 & 34.92 & 42.97 & 43.97 \\
$60-80$ & 40.00 & 4.08 & 10.20 & 36.16 & 39.56 & 44.27 \\
$80-100$ & 33.46 & 2.51 & 7.50 & 30.58 & 34.55 & 35.24 \\
\hline
\end{tabular}

Tabela C.2.4: Porosidade na área A4

\begin{tabular}{ccccccc}
\hline \multicolumn{7}{c}{ Porosidade (\%) } \\
\hline & \multicolumn{7}{c}{ A4 (6 anos) } \\
\cline { 2 - 7 } Profundidade $(\mathrm{cm})$ & Média & DP & CV & Mínimo & Mediana & Máximo \\
\hline $0-20$ & 44.08 & 3.56 & 8.08 & 41.99 & 42.06 & 48.19 \\
$20-40$ & 35.55 & 3.78 & 10.63 & 32.16 & 34.87 & 39.63 \\
$40-60$ & 36.75 & 2.94 & 8.00 & 33.54 & 37.37 & 39.33 \\
$60-80$ & 34.96 & 3.91 & 11.18 & 30.50 & 36.64 & 37.76 \\
$80-100$ & 34.95 & 2.15 & 6.15 & 32.48 & 35.93 & 36.43 \\
\hline
\end{tabular}

Tabela C.2.5: Porosidade na área A5

\begin{tabular}{ccccccc}
\hline & \multicolumn{7}{c}{ Porosidade (\%) } \\
\hline & \multicolumn{7}{c}{ A5 (mata nativa) } \\
\cline { 2 - 7 } Profundidade $(\mathrm{cm})$ & Média & DP & CV & Mínimo & Mediana & Máximo \\
\hline $0-20$ & 56.91 & 3.66 & 6.43 & 52.75 & 58.40 & 59.60 \\
$20-40$ & 45.20 & 0.17 & 0.38 & 45.01 & 45.24 & 45.34 \\
$40-60$ & 45.29 & 0.35 & 0.78 & 45.00 & 45.19 & 45.68 \\
$60-80$ & 45.28 & 0.63 & 1.39 & 44.77 & 45.10 & 45.99 \\
$80-100$ & 45.34 & 0.59 & 1.29 & 44.99 & 45.01 & 46.01 \\
\hline
\end{tabular}


Tabela C3.1: pH na área A1

\begin{tabular}{|c|c|c|c|c|c|c|}
\hline \multirow[b]{3}{*}{ Profundidade $(\mathrm{cm})$} & \multicolumn{5}{|c|}{$\mathrm{pH}$} & \\
\hline & \multicolumn{6}{|c|}{ A1 (14 anos) } \\
\hline & Média & DP & $\mathrm{CV}$ & Mínimo & Mediana & Máximo \\
\hline $0-20$ & 3.77 & 0.25 & 6.69 & 3.50 & 3.80 & 4.00 \\
\hline $20-40$ & 3.47 & 0.21 & 6.00 & 3.30 & 3.40 & 3.70 \\
\hline $40-60$ & 3.47 & 0.12 & 3.33 & 3.40 & 3.40 & 3.60 \\
\hline $60-80$ & 3.50 & 0.20 & 5.71 & 3.30 & 3.50 & 3.70 \\
\hline $80-100$ & 3.50 & 0.10 & 2.86 & 3.40 & 3.50 & 3.60 \\
\hline \multicolumn{7}{|c|}{ Tabela C3.2: $\mathrm{pH}$ na área A2 } \\
\hline \multicolumn{7}{|c|}{$\mathrm{pH}$} \\
\hline & \multicolumn{6}{|c|}{ A2 (11 anos) } \\
\hline Profundidade $(\mathrm{cm})$ & Média & $\mathrm{DP}$ & $\mathrm{CV}$ & Mínimo & Mediana & Máximo \\
\hline $0-20$ & 4.40 & 0.27 & 6.02 & 4.20 & 4.30 & 4.70 \\
\hline $20-40$ & 3.93 & 0.06 & 1.47 & 3.90 & 3.90 & 4.00 \\
\hline $40-60$ & 3.97 & 0.06 & 1.45 & 3.90 & 4.00 & 4.00 \\
\hline $60-80$ & 4.90 & 0.20 & 4.08 & 4.70 & 4.90 & 5.10 \\
\hline $80-100$ & 5.50 & 0.40 & 7.27 & 5.10 & 5.50 & 5.90 \\
\hline
\end{tabular}

Tabela C3.3: $\mathrm{pH}$ na área $\mathrm{A} 3$

\begin{tabular}{ccccccc}
\hline & \multicolumn{7}{c}{$\mathrm{pH}$} \\
\hline & \multicolumn{7}{c}{ A3 (8 anos) } \\
\cline { 2 - 7 } Profundidade $(\mathrm{cm})$ & Média & DP & CV & Mínimo & Mediana & Máximo \\
\hline $0-20$ & 3.87 & 0.32 & 8.30 & 3.50 & 4.00 & 4.10 \\
$20-40$ & 3.63 & 0.06 & 1.59 & 3.60 & 3.60 & 3.70 \\
$40-60$ & 3.67 & 0.15 & 4.17 & 3.50 & 3.70 & 3.80 \\
$60-80$ & 3.87 & 0.15 & 3.95 & 3.70 & 3.90 & 4.00 \\
$80-100$ & 4.00 & 0.20 & 5.00 & 3.80 & 4.00 & 4.20 \\
\hline
\end{tabular}

Tabela A3.4: $\mathrm{pH}$ na área A4

\begin{tabular}{|c|c|c|c|c|c|c|}
\hline \multirow[b]{3}{*}{ Profundidade $(\mathrm{cm})$} & \multicolumn{5}{|c|}{$\mathrm{pH}$} & \\
\hline & \multicolumn{6}{|c|}{ A4 (6 anos) } \\
\hline & Média & $\mathrm{DP}$ & $\mathrm{CV}$ & Mínimo & Mediana & Máximo \\
\hline $0-20$ & 4.60 & 0.53 & 11.50 & 4.20 & 4.40 & 5.20 \\
\hline $20-40$ & 3.97 & 0.12 & 2.91 & 3.90 & 3.90 & 4.10 \\
\hline $40-60$ & 4.00 & 0.17 & 4.33 & 3.80 & 4.10 & 4.10 \\
\hline $60-80$ & 4.03 & 0.21 & 5.16 & 3.80 & 4.10 & 4.20 \\
\hline $80-100$ & 4.30 & 0.56 & 12.95 & 3.80 & 4.20 & 4.90 \\
\hline
\end{tabular}

Tabela C3.5: pH na área A5

\begin{tabular}{ccccccc}
\hline & \multicolumn{7}{c}{$\mathrm{pH}$} \\
\hline & \multicolumn{7}{c}{ A5 (mata nativa) } \\
\cline { 2 - 7 } Profundidade $(\mathrm{cm})$ & Média & DP & CV & Mínimo & Mediana & Máximo \\
\hline $0-20$ & 3.60 & 0.20 & 5.56 & 3.40 & 3.60 & 3.80 \\
$20-40$ & 3.83 & 0.06 & 1.51 & 3.80 & 3.80 & 3.90 \\
$40-60$ & 3.90 & 0.00 & 0.00 & 3.90 & 3.90 & 3.90 \\
$60-80$ & 3.83 & 0.06 & 1.51 & 3.80 & 3.80 & 3.90 \\
$80-100$ & 3.87 & 0.06 & 1.49 & 3.80 & 3.90 & 3.90 \\
\hline
\end{tabular}


Tabela C3.6: $\mathrm{pH}$ na área $\mathrm{A} 6$

\begin{tabular}{ccccccc}
\hline & \multicolumn{7}{c}{$\mathrm{pH}$} \\
\hline & \multicolumn{7}{c}{ A6 (sem vegetação) } \\
\cline { 2 - 7 } Profundidade $(\mathrm{cm})$ & Média & DP & CV & Mínimo & Mediana & Máximo \\
\hline $0-20$ & 4.03 & 0.15 & 3.79 & 3.90 & 4.00 & 4.20 \\
$20-40$ & 4.10 & 0.00 & 0.00 & 4.10 & 4.10 & 4.10 \\
$40-60$ & 4.10 & 0.00 & 0.00 & 4.10 & 4.10 & 4.10 \\
$60-80$ & 4.13 & 0.06 & 1.40 & 4.10 & 4.10 & 4.20 \\
$80-100$ & 4.20 & 0.10 & 2.38 & 4.10 & 4.20 & 4.30 \\
\hline
\end{tabular}

Tabela C4.1: Matéria orgânica na área A1

\begin{tabular}{ccccccc}
\hline \multicolumn{7}{c}{ Matéria Orgânica $\left(\mathrm{mmolc} / \mathrm{dm}^{3}\right)$} \\
\hline \multirow{7}{*}{ Profundidade $(\mathrm{cm})$} & Média & DP & CV & Mínimo & Mediana & Máximo \\
\cline { 2 - 7 } & 23.00 & 3.61 & 15.70 & 20.00 & 22.00 & 27.00 \\
$20-20$ & 16.00 & 3.00 & 18.75 & 13.00 & 16.00 & 19.00 \\
$40-60$ & 15.67 & 2.52 & 16.08 & 13.00 & 16.00 & 18.00 \\
$60-80$ & 15.33 & 4.04 & 26.35 & 11.00 & 16.00 & 19.00 \\
$80-100$ & 16.67 & 4.93 & 29.57 & 11.00 & 19.00 & 20.00 \\
\hline
\end{tabular}

Tabela C4.2: Matéria orgânica na área A2

\begin{tabular}{ccccccc}
\hline \multicolumn{7}{c}{ Matéria Orgânica $\left(\mathrm{mmolc} / \mathrm{dm}^{3}\right)$} \\
\hline & \multicolumn{7}{c}{ A2 (11 anos) } \\
\cline { 2 - 7 } Profundidade $(\mathrm{cm})$ & Média & DP & CV & Mínimo & Mediana & Máximo \\
\hline $0-20$ & 14.00 & 2.65 & 18.93 & 11.00 & 15.00 & 16.00 \\
$20-40$ & 9.33 & 1.16 & 12.38 & 8.00 & 10.00 & 10.00 \\
$40-60$ & 7.33 & 1.53 & 20.84 & 6.00 & 7.00 & 9.00 \\
$60-80$ & 6.33 & 0.58 & 9.11 & 6.00 & 6.00 & 7.00 \\
$80-100$ & 5.67 & 1.53 & 26.96 & 4.00 & 6.00 & 7.00 \\
\hline
\end{tabular}

Tabela C4.3: Matéria orgânica na área A3

Matéria Orgânica $\left(\mathrm{mmolc} / \mathrm{dm}^{3}\right)$

\begin{tabular}{ccccccc}
\hline \multicolumn{7}{c}{ Matéria Orgânica $\left(\mathrm{mmolc} / \mathrm{dm}^{3}\right)$} \\
\hline & Média & DP & CV & Mínimo & Mediana & Máximo \\
\cline { 2 - 7 } Profundidade (cm) & 26.67 & 4.93 & 18.49 & 21.00 & 29.00 & 30.00 \\
$0-20$ & 17.67 & 2.08 & 11.77 & 16.00 & 17.00 & 20.00 \\
$20-40$ & 15.00 & 7.21 & 48.07 & 7.00 & 17.00 & 21.00 \\
$40-60$ & 8.00 & 2.65 & 33.13 & 6.00 & 7.00 & 11.00 \\
$60-80$ & 6.33 & 0.58 & 9.11 & 6.00 & 6.00 & 7.00 \\
$80-100$ & & & & & & \\
\hline
\end{tabular}

Tabela C4.4: Matéria orgânica na área A4

\begin{tabular}{ccccccc}
\hline \multicolumn{7}{c}{ Matéria Orgânica $\left(\mathrm{mmolc} / \mathrm{dm}^{3}\right)$} \\
\hline & Média & DP & CV & Mínimo & Mediana & Máximo \\
\cline { 2 - 7 } Profundidade $(\mathrm{cm})$ & 21.33 & 2.31 & 10.83 & 20.00 & 20.00 & 24.00 \\
$0-20$ & 9.67 & 3.79 & 39.19 & 7.00 & 8.00 & 14.00 \\
$20-40$ & 8.33 & 3.21 & 38.54 & 6.00 & 7.00 & 12.00 \\
$40-60$ & 9.33 & 6.66 & 71.38 & 5.00 & 6.00 & 17.00 \\
$60-80$ & 6.33 & 0.58 & 9.11 & 6.00 & 6.00 & 7.00 \\
$80-100$ & & & & & & \\
\hline
\end{tabular}


Tabela C4.5: Matéria orgânica na área A5

\begin{tabular}{ccccccc}
\hline \multicolumn{7}{c}{ Matéria Orgânica $\left(\mathrm{mmolc} / \mathrm{dm}^{3}\right)$} \\
\hline & Média & DP & CV & Mínimo & Mediana & Máximo \\
\cline { 2 - 7 } Profundidade (cm) & 25.33 & 5.03 & 19.86 & 20.00 & 26.00 & 30.00 \\
\hline $0-20$ & 13.33 & 0.58 & 4.33 & 13.00 & 13.00 & 14.00 \\
$20-40$ & 11.00 & 1.00 & 9.09 & 10.00 & 11.00 & 12.00 \\
$40-60$ & 9.33 & 1.16 & 12.38 & 8.00 & 10.00 & 10.00 \\
$60-80$ & 9.00 & 1.00 & 11.11 & 8.00 & 9.00 & 10.00 \\
$80-100$ & & & & & & \\
\hline
\end{tabular}

Tabela C4.6: Matéria orgânica na área A6

\begin{tabular}{ccccccc}
\hline \multicolumn{7}{c}{ Matéria Orgânica $\left(\mathrm{mmolc} / \mathrm{dm}^{3}\right)$} \\
\hline & \multicolumn{7}{c}{ A6 (sem vegetação) } \\
\cline { 2 - 7 } Profundidade (cm) & Média & DP & CV & Mínimo & Mediana & Máximo \\
\hline $0-20$ & 7.00 & 1.00 & 14.29 & 6.00 & 7.00 & 8.00 \\
$20-40$ & 6.67 & 0.58 & 8.65 & 6.00 & 7.00 & 7.00 \\
$40-60$ & 6.67 & 0.58 & 8.65 & 6.00 & 7.00 & 7.00 \\
$60-80$ & 6.33 & 0.58 & 9.11 & 6.00 & 6.00 & 7.00 \\
$80-100$ & 6.00 & 1.00 & 16.67 & 5.00 & 6.00 & 7.00 \\
\hline
\end{tabular}

Tabela C5.1: Fósforo na área A1

\begin{tabular}{ccccccc}
\hline \multicolumn{7}{c}{ Fósforo $\left(\mathrm{mg} / \mathrm{dm}^{3}\right)$} \\
\hline & Média & DP & CV & Mínimo & Mediana & Máximo \\
\cline { 2 - 7 } Profundidade $(\mathrm{cm})$ & 8.33 & 4.04 & 48.50 & 6.00 & 6.00 & 13.00 \\
$0-20$ & 8.00 & 3.61 & 45.13 & 4.00 & 9.00 & 11.00 \\
$20-40$ & 6.00 & 2.65 & 44.17 & 4.00 & 5.00 & 9.00 \\
$40-60$ & 4.67 & 1.53 & 32.74 & 3.00 & 5.00 & 6.00 \\
$60-80$ & 5.00 & 2.65 & 53.00 & 3.00 & 4.00 & 8.00 \\
$80-100$ & & & & & & \\
\hline
\end{tabular}

Tabela C5.2: Fósforo na área $A 2$

\begin{tabular}{cccccccc}
\hline & \multicolumn{7}{c}{ Fósforo $\left(\mathrm{mg} / \mathrm{dm}^{3}\right)$} \\
\cline { 2 - 7 } Profundidade $(\mathrm{cm})$ & Média & DP & CV & Mínimo & Mediana & Máximo \\
\cline { 2 - 7 } & \multicolumn{7}{c}{ A2 (11 anos) } \\
$20-40$ & 8.33 & 4.16 & 49.94 & 5.00 & 7.00 & 13.00 \\
$40-60$ & 1.00 & 0.00 & 0.00 & 1.00 & 1.00 & 1.00 \\
$60-80$ & 1.00 & 0.00 & 0.00 & 1.00 & 1.00 & 1.00 \\
$80-100$ & 1.33 & 0.58 & 43.29 & 1.00 & 1.00 & 2.00 \\
\hline
\end{tabular}

Tabela C5.3: Fósforo na área $\mathrm{A} 3$

\begin{tabular}{ccccccc}
\hline \multicolumn{7}{c}{ Fósforo $\left(\mathrm{mg} / \mathrm{dm}^{3}\right)$} \\
\hline & Média & DP & CV & Mínimo & Mediana & Máximo \\
\cline { 2 - 7 } Profundidade $(\mathrm{cm})$ & 10.00 & 4.58 & 45.80 & 5.00 & 11.00 & 14.00 \\
$0-20$ & 3.00 & 1.00 & 33.33 & 2.00 & 3.00 & 4.00 \\
$20-40$ & 2.00 & 1.00 & 50.00 & 1.00 & 2.00 & 3.00 \\
$40-60$ & 1.67 & 0.58 & 34.61 & 1.00 & 2.00 & 2.00 \\
$60-80$ & 1.00 & 0.00 & 0.00 & 1.00 & 1.00 & 1.00 \\
$80-100$ & & & & & & \\
\hline
\end{tabular}


Tabela C5.4: Fósforo na área $\mathrm{A} 4$

\begin{tabular}{ccccccc}
\hline \multicolumn{7}{c}{ Fósforo $\left(\mathrm{mg} / \mathrm{dm}^{3}\right)$} \\
\hline & Média & DP & CV & Mínimo & Mediana & Máximo \\
\cline { 2 - 7 } Profundidade $(\mathrm{cm})$ & 12.67 & 3.21 & 25.34 & 9.00 & 14.00 & 15.00 \\
\hline $0-20$ & 1.33 & 0.58 & 43.29 & 1.00 & 1.00 & 2.00 \\
$20-40$ & 1.00 & 0.00 & 0.00 & 1.00 & 1.00 & 1.00 \\
$40-60$ & 1.33 & 0.58 & 43.29 & 1.00 & 1.00 & 2.00 \\
$60-80$ & 1.00 & 0.00 & 0.00 & 1.00 & 1.00 & 1.00 \\
$80-100$ & & & & & & \\
\hline
\end{tabular}

Tabela C5.5: Fósforo na área A5

\begin{tabular}{cccccccc}
\hline \multicolumn{7}{c}{ Fósforo $\left(\mathrm{mg} / \mathrm{dm}^{3}\right)$} \\
\hline \multirow{7}{*}{ Profundidade (cm) } & Média & DP & CV & Mínimo & Mediana & Máximo \\
\cline { 2 - 7 } $0-20$ & 5.33 & 1.53 & 28.65 & 4.00 & 5.00 & 7.00 \\
$20-40$ & 1.67 & 0.58 & 34.61 & 1.00 & 2.00 & 2.00 \\
$40-60$ & 1.00 & 0.00 & 0.00 & 1.00 & 1.00 & 1.00 \\
$60-80$ & 1.00 & 0.00 & 0.00 & 1.00 & 1.00 & 1.00 \\
$80-100$ & 1.00 & 0.00 & 0.00 & 1.00 & 1.00 & 1.00 \\
\hline
\end{tabular}

Tabela C5.6: Fósforo na área A6

\begin{tabular}{ccccccc}
\hline \multicolumn{7}{c}{ Fósforo $\left(\mathrm{mg} / \mathrm{dm}^{3}\right)$} \\
\hline \multirow{2}{*}{ Profundidade $(\mathrm{cm})$} & Média & DP & CV & Mínimo & Mediana & Máximo \\
\cline { 2 - 7 } $0-20$ & 1.00 & 0.00 & 0.00 & 1.00 & 1.00 & 1.00 \\
$20-40$ & 1.00 & 0.00 & 0.00 & 1.00 & 1.00 & 1.00 \\
$40-60$ & 1.00 & 0.00 & 0.00 & 1.00 & 1.00 & 1.00 \\
$60-80$ & 1.00 & 0.00 & 0.00 & 1.00 & 1.00 & 1.00 \\
$80-100$ & 1.00 & 0.00 & 0.00 & 1.00 & 1.00 & 1.00 \\
\hline
\end{tabular}

Tabela C6.1: Potássio na área A1

\begin{tabular}{ccccccc}
\hline \multicolumn{7}{c}{ Tabela C6.1: Potássio na área A1 } \\
\hline \multirow{7}{*}{ Potássio $\left(\mathrm{mmolc} / \mathrm{dm}^{3}\right)$} \\
\cline { 2 - 7 } Profundidade $(\mathrm{cm})$ & Média & DP & CV & Mínimo & Mediana & Máximo \\
\hline 0.20 & 0.67 & 0.06 & 8.65 & 0.60 & 0.70 & 0.70 \\
$20-40$ & 0.27 & 0.06 & 21.63 & 0.20 & 0.30 & 0.30 \\
$40-60$ & 0.27 & 0.06 & 21.63 & 0.20 & 0.30 & 0.30 \\
$60-80$ & 0.23 & 0.06 & 24.73 & 0.20 & 0.20 & 0.30 \\
$80-100$ & 0.20 & 0.00 & 0.00 & 0.20 & 0.20 & 0.20 \\
\hline
\end{tabular}

Tabela C6.2: Potássio na área A2

\begin{tabular}{cccccccc}
\hline \multicolumn{7}{c}{ Potássio $\left(\mathrm{mmolc} / \mathrm{dm}^{3}\right)$} \\
\hline \multirow{7}{*}{ Profundidade $(\mathrm{cm})$} & Média & DP & CV & Mínimo & Mediana & Máximo \\
\cline { 2 - 8 } $0-20$ & 0.53 & 0.21 & 39.02 & 0.30 & 0.60 & 0.70 \\
$20-40$ & 0.10 & 0.00 & 0.00 & 0.10 & 0.10 & 0.10 & 0.10 \\
$40-60$ & 0.10 & 0.00 & 0.00 & 0.10 & 0.10 & 0.10 & 0.10 \\
$60-80$ & 0.10 & 0.00 & 0.00 & 0.10 & 0 & 0.10 \\
$80-100$ & 0.10 & 0.00 & 0.00 & 0.10 & 0.10 & 0.10 \\
\hline
\end{tabular}


Tabela C6.3: Potássio na área $\mathrm{A} 3$

\begin{tabular}{ccccccc}
\hline \multicolumn{7}{c}{ Potássio $\left(\mathrm{mmolc} / \mathrm{dm}^{3}\right)$} \\
\hline \multirow{2}{*}{ Profundidade (cm) } & Média & DP & CV & Mínimo & Mediana & Máximo \\
\cline { 2 - 7 } & 0.60 & 0.00 & 0.00 & 0.60 & 0.60 & 0.60 \\
$20-40$ & 0.20 & 0.00 & 0.00 & 0.20 & 0.20 & 0.20 \\
$40-60$ & 0.20 & 0.00 & 0.00 & 0.20 & 0.20 & 0.20 \\
$60-80$ & 0.13 & 0.06 & 43.29 & 0.10 & 0.10 & 0.20 \\
$80-100$ & 0.10 & 0.00 & 0.00 & 0.10 & 0.10 & 0.10 \\
\hline
\end{tabular}

Tabela C6.4: Potássio na área A4

\begin{tabular}{ccccccc}
\hline \multicolumn{7}{c}{ Potássio $\left(\mathrm{mmolc} / \mathrm{dm}^{3}\right)$} \\
\hline & \multicolumn{7}{c}{ A4 (6 anos) } \\
\cline { 2 - 7 } Profundidade $(\mathrm{cm})$ & Média & DP & CV & Mínimo & Mediana & Máximo \\
\hline $0-20$ & 0.80 & 0.17 & 21.63 & 0.70 & 0.70 & 1.00 \\
$20-40$ & 0.13 & 0.06 & 43.29 & 0.10 & 0.10 & 0.20 \\
$40-60$ & 0.10 & 0.00 & 0.00 & 0.10 & 0.10 & 0.10 \\
$60-80$ & 0.10 & 0.00 & 0.00 & 0.10 & 0.10 & 0.10 \\
$80-100$ & 0.10 & 0.00 & 0.00 & 0.10 & 0.10 & 0.10 \\
\hline
\end{tabular}

Tabela C6.5: Potássio na área A5

\begin{tabular}{ccccccc}
\hline & \multicolumn{7}{c}{ Potássio $\left(\mathrm{mmolc} / \mathrm{dm}^{3}\right)$} \\
\cline { 2 - 7 } Profundidade $(\mathrm{cm})$ & Média & DP & CV & Mínimo & Mediana & Máximo \\
\hline 0.20 & 0.63 & 0.06 & 9.11 & 0.60 & 0.60 & 0.70 \\
$20-40$ & 0.23 & 0.12 & 49.51 & 0.10 & 0.30 & 0.30 \\
$40-60$ & 0.10 & 0.00 & 0.00 & 0.10 & 0.10 & 0.10 \\
$60-80$ & 0.10 & 0.00 & 0.00 & 0.10 & 0.10 & 0.10 \\
$80-100$ & 0.10 & 0.00 & 0.00 & 0.10 & 0.10 & 0.10 \\
\hline
\end{tabular}

Tabela C6.6: Potássio na área A6

\begin{tabular}{ccccccc}
\hline \multicolumn{7}{c}{ Potássio $\left(\mathrm{mmolc} / \mathrm{dm}^{3}\right)$} \\
\hline & \multicolumn{7}{c}{ A6 (sem vegetação) } \\
\cline { 2 - 7 } Profundidade $(\mathrm{cm})$ & Média & DP & CV & Mínimo & Mediana & Máximo \\
\hline $0-20$ & 0.10 & 0.00 & 0.00 & 0.10 & 0.10 & 0.10 \\
$20-40$ & 0.10 & 0.00 & 0.00 & 0.10 & 0.10 & 0.10 \\
$40-60$ & 0.13 & 0.06 & 43.29 & 0.10 & 0.10 & 0.20 \\
$60-80$ & 0.10 & 0.00 & 0.00 & 0.10 & 0.10 & 0.10 \\
$80-100$ & 0.13 & 0.06 & 43.29 & 0.10 & 0.10 & 0.20 \\
\hline
\end{tabular}

Tabela C7.1: Cálcio na área A1

\begin{tabular}{ccccccc}
\hline \multicolumn{7}{c}{ Cálcio $\left(\mathrm{mmolc} / \mathrm{dm}^{3}\right)$} \\
\hline & \multicolumn{7}{c}{ A1 (14 anos) } \\
\cline { 2 - 7 } Profundidade $(\mathrm{cm})$ & Média & DP & CV & Mínimo & Mediana & Máximo \\
\hline $0-20$ & 6.00 & 0.00 & 0.00 & 6.00 & 6.00 & 6.00 \\
$20-40$ & 1.00 & 0.00 & 0.00 & 1.00 & 1.00 & 1.00 \\
$40-60$ & 1.33 & 0.58 & 43.29 & 1.00 & 1.00 & 2.00 \\
$60-80$ & 1.00 & 0.00 & 0.00 & 1.00 & 1.00 & 1.00 \\
$80-100$ & 1.00 & 0.00 & 0.00 & 1.00 & 1.00 & 1.00 \\
\hline
\end{tabular}


Tabela C7.2: Cálcio na área A2

\begin{tabular}{ccccccc}
\hline \multicolumn{7}{c}{ Cálcio $\left(\mathrm{mmolc} / \mathrm{dm}^{3}\right)$} \\
\hline \multirow{2}{*}{ Profundidade $(\mathrm{cm})$} & Média & DP & CV & Mínimo & Mediana & Máximo \\
\cline { 2 - 7 } $0-20$ & 7.67 & 1.16 & 15.06 & 7.00 & 7.00 & 9.00 \\
$20-40$ & 1.67 & 0.58 & 34.61 & 1.00 & 2.00 & 2.00 \\
$40-60$ & 1.33 & 0.58 & 43.29 & 1.00 & 1.00 & 2.00 \\
$60-80$ & 3.33 & 1.53 & 45.84 & 2.00 & 3.00 & 5.00 \\
$80-100$ & 3.00 & 1.00 & 33.33 & 2.00 & 3.00 & 4.00 \\
\hline
\end{tabular}

Tabela C7.3: Cálcio na área A3

\begin{tabular}{ccccccc}
\hline \multicolumn{7}{c}{ Cálcio $\left(\mathrm{mmolc} / \mathrm{dm}^{3}\right)$} \\
\hline \multirow{7}{*}{ Profundidade $(\mathrm{cm})$} & Média & DP & CV & Mínimo & Mediana & Máximo \\
\cline { 2 - 7 } & 7.33 & 3.21 & 43.79 & 5.00 & 6.00 & 11.00 \\
$20-20$ & 1.67 & 0.58 & 34.61 & 1.00 & 2.00 & 2.00 \\
$40-60$ & 1.33 & 0.58 & 43.29 & 1.00 & 1.00 & 2.00 \\
$60-80$ & 1.00 & 0.00 & 0.00 & 1.00 & 1.00 & 1.00 \\
$80-100$ & 1.33 & 0.58 & 43.29 & 1.00 & 1.00 & 2.00 \\
\hline
\end{tabular}

Tabela C7.4: Cálcio na área A4

\begin{tabular}{ccccccc}
\hline \multicolumn{7}{c}{ Cálcio $\left(\mathrm{mmolc} / \mathrm{dm}^{3}\right)$} \\
\hline & \multicolumn{7}{c}{ A4 (6 anos) } \\
\cline { 2 - 7 } Profundidade $(\mathrm{cm})$ & Média & DP & CV & Mínimo & Mediana & Máximo \\
\hline $0-20$ & 15.00 & 10.44 & 69.60 & 8.00 & 10.00 & 27.00 \\
$20-40$ & 2.33 & 0.58 & 24.73 & 2.00 & 2.00 & 3.00 \\
$40-60$ & 1.33 & 0.58 & 43.29 & 1.00 & 1.00 & 2.00 \\
$60-80$ & 1.33 & 0.58 & 43.29 & 1.00 & 1.00 & 2.00 \\
$80-100$ & 3.00 & 2.65 & 88.33 & 1.00 & 2.00 & 6.00 \\
\hline
\end{tabular}

Tabela C7.5: Cálcio na área A5

\begin{tabular}{ccccccc}
\hline \multicolumn{7}{c}{ Cálcio $\left(\mathrm{mmolc} / \mathrm{dm}^{3}\right)$} \\
\hline & \multicolumn{7}{c}{ A5 (mata nativa) } \\
\cline { 2 - 7 } Profundidade $(\mathrm{cm})$ & Média & DP & CV & Mínimo & Mediana & Máximo \\
\hline $0-20$ & 1.33 & 0.58 & 43.29 & 1.00 & 1.00 & 2.00 \\
$20-40$ & 1.00 & 0.00 & 0.00 & 1.00 & 1.00 & 1.00 \\
$40-60$ & 1.00 & 0.00 & 0.00 & 1.00 & 1.00 & 1.00 \\
$60-80$ & 1.67 & 1.16 & 69.29 & 1.00 & 1.00 & 3.00 \\
$80-100$ & 1.00 & 0.00 & 0.00 & 1.00 & 1.00 & 1.00 \\
\hline
\end{tabular}

Tabela C7.6: Cálcio na área A6

\begin{tabular}{ccccccc}
\hline \multicolumn{7}{c}{ Cálcio $\left(\mathrm{mmolc} / \mathrm{dm}^{3}\right)$} \\
\hline & \multicolumn{7}{c}{ A6 (sem vegetação) } \\
\cline { 2 - 7 } Profundidade $(\mathrm{cm})$ & Média & DP & CV & Mínimo & Mediana & Máximo \\
\hline $0-20$ & 1.00 & 0.00 & 0.00 & 1.00 & 1.00 & 1.00 \\
$20-40$ & 1.00 & 0.00 & 0.00 & 1.00 & 1.00 & 1.00 \\
$40-60$ & 1.67 & 1.16 & 69.29 & 1.00 & 1.00 & 3.00 \\
$60-80$ & 1.33 & 0.58 & 43.29 & 1.00 & 1.00 & 2.00 \\
$80-100$ & 3.33 & 4.04 & 121.32 & 1.00 & 1.00 & 8.00 \\
\hline
\end{tabular}


Tabela C8.1: Magnésio na área A1

\begin{tabular}{ccccccc}
\hline \multicolumn{7}{c}{ Magnésio $\left(\mathrm{mmolc} / \mathrm{dm}^{3}\right)$} \\
\hline \multirow{2}{*}{ Profundidade $(\mathrm{cm})$} & Média & DP & CV & Mínimo & Mediana & Máximo \\
\cline { 2 - 7 } & 3.33 & 0.58 & 17.31 & 3.00 & 3.00 & 4.00 \\
$20-20$ & 1.00 & 0.00 & 0.00 & 1.00 & 1.00 & 1.00 \\
$40-60$ & 1.00 & 0.00 & 0.00 & 1.00 & 1.00 & 1.00 \\
$60-80$ & 1.00 & 0.00 & 0.00 & 1.00 & 1.00 & 1.00 \\
$80-100$ & 1.00 & 0.00 & 0.00 & 1.00 & 1.00 & 1.00 \\
\hline
\end{tabular}

Tabela C8.2: Magnésio na área A2

\begin{tabular}{ccccccc}
\hline \multicolumn{7}{c}{ Magnésio $\left(\mathrm{mmolc} / \mathrm{dm}^{3}\right)$} \\
\hline & \multicolumn{7}{c}{ A2 (11 anos) } \\
\cline { 2 - 7 } Profundidade $(\mathrm{cm})$ & Média & DP & CV & Mínimo & Mediana & Máximo \\
\hline $0-20$ & 4.00 & 1.00 & 25.00 & 3.00 & 4.00 & 5.00 \\
$20-40$ & 1.00 & 0.00 & 0.00 & 1.00 & 1.00 & 1.00 \\
$40-60$ & 1.00 & 0.00 & 0.00 & 1.00 & 1.00 & 1.00 \\
$60-80$ & 1.67 & 0.58 & 34.61 & 1.00 & 2.00 & 2.00 \\
$80-100$ & 2.00 & 1.00 & 50.00 & 1.00 & 2.00 & 3.00 \\
\hline
\end{tabular}

Tabela C8.3: Magnésio na área A3

\begin{tabular}{ccccccc}
\hline \multicolumn{7}{c}{ Magnésio $\left(\mathrm{mmolc} / \mathrm{dm}^{3}\right)$} \\
\hline \multirow{2}{*}{ Profundidade $(\mathrm{cm})$} & Média & DP & CV & Mínimo & Mediana & Máximo \\
\cline { 2 - 7 } $0-20$ & 4.67 & 3.79 & 81.16 & 2.00 & 3.00 & 9.00 \\
$20-40$ & 1.00 & 0.00 & 0.00 & 1.00 & 1.00 & 1.00 \\
$40-60$ & 1.00 & 0.00 & 0.00 & 1.00 & 1.00 & 1.00 \\
$60-80$ & 1.00 & 0.00 & 0.00 & 1.00 & 1.00 & 1.00 \\
$80-100$ & 1.00 & 0.00 & 0.00 & 1.00 & 1.00 & 1.00 \\
\hline
\end{tabular}

Tabela C8.4: Magnésio na área A4

\begin{tabular}{ccccccc}
\hline \multicolumn{7}{c}{ Magnésio $\left(\mathrm{mmolc} / \mathrm{dm}^{3}\right)$} \\
\hline & \multicolumn{7}{c}{ A4 (6 anos) } \\
\cline { 2 - 7 } Profundidade $(\mathrm{cm})$ & Média & DP & CV & Mínimo & Mediana & Máximo \\
\hline $0-20$ & 9.00 & 8.72 & 96.89 & 3.00 & 5.00 & 19.00 \\
$20-40$ & 1.33 & 0.58 & 43.29 & 1.00 & 1.00 & 2.00 \\
$40-60$ & 1.00 & 0.00 & 0.00 & 1.00 & 1.00 & 1.00 \\
$60-80$ & 1.00 & 0.00 & 0.00 & 1.00 & 1.00 & 1.00 \\
$80-100$ & 1.33 & 0.58 & 43.29 & 1.00 & 1.00 & 2.00 \\
\hline
\end{tabular}

Tabela C8.5: Magnésio na área A5

\begin{tabular}{ccccccc}
\hline \multicolumn{7}{c}{ Magnésio $\left(\mathrm{mmolc} / \mathrm{dm}^{3}\right)$} \\
\hline & \multicolumn{7}{c}{ A5 (mata nativa) } \\
\cline { 2 - 7 } Profundidade $(\mathrm{cm})$ & Média & DP & CV & Mínimo & Mediana & Máximo \\
\hline $0-20$ & 1.00 & 0.00 & 0.00 & 1.00 & 1.00 & 1.00 \\
$20-40$ & 1.00 & 0.00 & 0.00 & 1.00 & 1.00 & 1.00 \\
$40-60$ & 1.00 & 0.00 & 0.00 & 1.00 & 1.00 & 1.00 \\
$60-80$ & 1.00 & 0.00 & 0.00 & 1.00 & 1.00 & 1.00 \\
$80-100$ & 1.00 & 0.00 & 0.00 & 1.00 & 1.00 & 1.00 \\
\hline
\end{tabular}


Tabela C8.6: Magnésio na área A6

\begin{tabular}{ccccccc}
\hline \multicolumn{7}{c}{ Magnésio $\left(\mathrm{mmolc} / \mathrm{dm}^{3}\right)$} \\
\hline \multirow{2}{*}{ Profundidade $(\mathrm{cm})$} & Média & DP & CV & Mínimo & Mediana & Máximo \\
\cline { 2 - 7 } & 1.00 & 0.00 & 0.00 & 1.00 & 1.00 & 1.00 \\
$20-40$ & 1.00 & 0.00 & 0.00 & 1.00 & 1.00 & 1.00 \\
$40-60$ & 1.33 & 0.58 & 43.29 & 1.00 & 1.00 & 2.00 \\
$60-80$ & 1.00 & 0.00 & 0.00 & 1.00 & 1.00 & 1.00 \\
$80-100$ & 1.67 & 1.16 & 69.29 & 1.00 & 1.00 & 3.00 \\
\hline
\end{tabular}

Tabela C9.1: Soma de Bases na área A1

\begin{tabular}{ccccccc}
\hline \multicolumn{7}{c}{ Toma de bases $\left(\mathrm{mmolc} / \mathrm{dm}^{3}\right)$} \\
\hline \multirow{7}{*}{ Profundidade $(\mathrm{cm})$} & Média & DP & CV & M1 (14 anos) \\
\cline { 2 - 7 } & 10.00 & 0.61 & 6.08 & 9.60 & 9.70 & 10.70 \\
\hline $0-20$ & 2.27 & 0.06 & 2.55 & 2.20 & 2.30 & 2.30 \\
$20-40$ & 2.60 & 0.61 & 23.38 & 2.20 & 2.30 & 3.30 \\
$40-60$ & 2.23 & 0.06 & 2.58 & 2.20 & 2.20 & 2.30 \\
$60-80$ & 2.20 & 0.00 & 0.00 & 2.20 & 2.20 & 2.20 \\
\hline $80-100$ & & & & & Mediana & \\
\hline
\end{tabular}

Tabela C9.2: Soma de Bases na área A2

\begin{tabular}{ccccccc}
\hline \multicolumn{7}{c}{ Soma de bases $\left(\mathrm{mmolc} / \mathrm{dm}^{3}\right)$} \\
\hline & \multicolumn{7}{c}{ A2 (11 anos) } \\
\cline { 2 - 7 } Profundidade $(\mathrm{cm})$ & Média & DP & CV & Mínimo & Mediana & Máximo \\
\hline $0-20$ & 12.20 & 2.19 & 17.95 & 10.30 & 11.70 & 14.60 \\
$20-40$ & 2.77 & 0.58 & 20.85 & 2.10 & 3.10 & 3.10 \\
$40-60$ & 2.43 & 0.58 & 23.72 & 2.10 & 2.10 & 3.10 \\
$60-80$ & 5.10 & 2.00 & 39.22 & 3.10 & 5.10 & 7.10 \\
$80-100$ & 5.10 & 1.73 & 33.92 & 3.10 & 6.10 & 6.10 \\
\hline
\end{tabular}

Tabela C9.3: Soma de Bases na área A3

\begin{tabular}{ccccccc}
\hline \multicolumn{7}{c}{ Tabela C9.3: Soma de Bases na área A3 } \\
\hline \multicolumn{7}{c}{ Soma de bases $\left(\mathrm{mmolc} / \mathrm{dm}^{3}\right)$} \\
\cline { 2 - 7 } Profundidade $(\mathrm{cm})$ & Média & DP & CV & Mínimo & Mediana & Máximo \\
\cline { 2 - 7 } $0-20$ & 12.60 & 7.00 & 55.56 & 7.60 & 9.60 & 20.60 \\
$20-40$ & 2.87 & 0.58 & 20.13 & 2.20 & 3.20 & 3.20 \\
$40-60$ & 2.53 & 0.58 & 22.78 & 2.20 & 2.20 & 3.20 \\
$60-80$ & 2.13 & 0.06 & 2.70 & 2.10 & 2.10 & 2.20 \\
$80-100$ & 2.43 & 0.58 & 23.72 & 2.10 & 2.10 & 3.10 \\
\hline
\end{tabular}

Tabela C9.4: Soma de Bases na área A4

\begin{tabular}{ccccccc}
\hline \multicolumn{7}{c}{ Soma de bases $\left(\mathrm{mmolc} / \mathrm{dm}^{3}\right)$} \\
\hline & \multicolumn{7}{c}{ A4 (6 anos) } \\
\cline { 2 - 7 } Profundidade $(\mathrm{cm})$ & Média & DP & CV & Mínimo & Mediana & Máximo \\
\hline $0-20$ & 24.80 & 19.30 & 77.82 & 11.70 & 15.70 & 47.00 \\
$20-40$ & 3.80 & 1.13 & 29.66 & 3.10 & 3.20 & 5.10 \\
$40-60$ & 2.43 & 0.58 & 23.72 & 2.10 & 2.10 & 3.10 \\
$60-80$ & 2.43 & 0.58 & 23.72 & 2.10 & 2.10 & 3.10 \\
$80-100$ & 4.43 & 3.21 & 72.46 & 2.10 & 3.10 & 8.10 \\
\hline
\end{tabular}


Tabela C9.5: Soma de Bases na área A5

\begin{tabular}{ccccccc}
\hline \multicolumn{7}{c}{ Soma de bases $\left(\mathrm{mmolc} / \mathrm{dm}^{3}\right)$} \\
\hline \multirow{2}{*}{ Profundidade $(\mathrm{cm})$} & Média & DP & CV & Mínimo & Mediana & Máximo \\
\cline { 2 - 7 } & 2.97 & 0.55 & 18.57 & 2.60 & 2.70 & 3.60 \\
$0-20$ & 2.23 & 0.12 & 5.17 & 2.10 & 2.30 & 2.30 \\
$20-40$ & 2.10 & 0.00 & 0.00 & 2.10 & 2.10 & 2.10 \\
$40-60$ & 2.77 & 1.16 & 41.74 & 2.10 & 2.10 & 4.10 \\
$60-80$ & 2.10 & 0.00 & 0.00 & 2.10 & 2.10 & 2.10 \\
$80-100$ & & & & & & \\
\hline
\end{tabular}

Tabela C9.6: Soma de Bases na área A6

\begin{tabular}{ccccccc}
\hline \multicolumn{7}{c}{ Soma de bases $\left(\mathrm{mmolc} / \mathrm{dm}^{3}\right)$} \\
\hline \multirow{7}{*}{ Profundidade $(\mathrm{cm})$} & Média & DP & CV & Mínimo & Mediana & Máximo \\
\cline { 2 - 7 } $0-20$ & 2.10 & 0.00 & 0.00 & 2.10 & 2.10 & 2.10 \\
$20-40$ & 2.10 & 0.00 & 0.00 & 2.10 & 2.10 & 2.10 \\
$40-60$ & 3.13 & 1.79 & 57.19 & 2.10 & 2.10 & 5.20 \\
$60-80$ & 2.43 & 0.58 & 23.72 & 2.10 & 2.10 & 3.10 \\
$80-100$ & 5.13 & 5.17 & 100.78 & 2.10 & 2.20 & 11.10 \\
\hline
\end{tabular}

Tabela C10.1: Alumínio na área $\mathrm{A} 1$

\begin{tabular}{ccccccc}
\hline \multicolumn{7}{c}{ Alumínio $\left(\mathrm{mmolc} / \mathrm{dm}^{3}\right)$} \\
\hline & \multicolumn{7}{c}{ A1 (14 anos) } \\
\cline { 2 - 7 } Profundidade $(\mathrm{cm})$ & Média & DP & CV & Mínimo & Mediana & Máximo \\
\hline $0-20$ & 8.67 & 2.52 & 29.07 & 6.00 & 9.00 & 11.00 \\
$20-40$ & 11.67 & 2.52 & 21.59 & 9.00 & 12.00 & 14.00 \\
$40-60$ & 11.33 & 2.08 & 18.36 & 9.00 & 12.00 & 13.00 \\
$60-80$ & 11.67 & 2.52 & 21.59 & 9.00 & 12.00 & 14.00 \\
$80-100$ & 12.33 & 2.08 & 16.87 & 10.00 & 13.00 & 14.00 \\
\hline
\end{tabular}

Tabela C10.2: Alumínio na área $\mathrm{A} 2$

\begin{tabular}{ccccccc}
\hline \multicolumn{7}{c}{ Tlumínio $\left(\mathrm{mmolc} / \mathrm{dm}^{3}\right)$} \\
\hline & \multicolumn{7}{c}{ A2 (11 anos) } \\
\cline { 2 - 7 } Profundidade (cm) & Média & DP & CV & Mínimo & Mediana & Máximo \\
\hline $0-20$ & 4.33 & 1.16 & 26.66 & 3.00 & 5.00 & 5.00 \\
$20-40$ & 8.67 & 1.53 & 17.63 & 7.00 & 9.00 & 10.00 \\
$40-60$ & 8.33 & 1.53 & 18.34 & 7.00 & 8.00 & 10.00 \\
$60-80$ & 1.00 & 1.00 & 100.00 & 0.00 & 1.00 & 2.00 \\
$80-100$ & 0.00 & 0.00 & 0.00 & 0.00 & 0.00 & 0.00 \\
\hline
\end{tabular}

Tabela C10.3: Alumínio na área A3

\begin{tabular}{ccccccc}
\hline \multicolumn{7}{c}{ Alumínio $\left(\mathrm{mmolc} / \mathrm{dm}^{3}\right)$} \\
\hline & \multicolumn{7}{c}{ A3 (8 anos) } \\
\cline { 2 - 7 } Profundidade $(\mathrm{cm})$ & Média & DP & CV & Mínimo & Mediana & Máximo \\
\hline $0-20$ & 8.67 & 4.62 & 53.29 & 6.00 & 6.00 & 14.00 \\
$20-40$ & 10.33 & 1.53 & 14.79 & 9.00 & 10.00 & 12.00 \\
$40-60$ & 11.00 & 2.65 & 24.09 & 9.00 & 10.00 & 14.00 \\
$60-80$ & 9.33 & 1.16 & 12.38 & 8.00 & 10.00 & 10.00 \\
$80-100$ & 7.33 & 2.31 & 31.51 & 6.00 & 6.00 & 10.00 \\
\hline
\end{tabular}


Tabela C10.4: Alumínio na área $A 4$

\begin{tabular}{ccccccc}
\hline \multicolumn{7}{c}{ Alumínio $\left(\mathrm{mmolc} / \mathrm{dm}^{3}\right)$} \\
\hline \multirow{2}{*}{ Profundidade $(\mathrm{cm})$} & Média & DP & CV & Mínimo & Mediana & Máximo \\
\cline { 2 - 7 } & 4.00 & 3.46 & 86.50 & 0.00 & 6.00 & 6.00 \\
$20-40$ & 9.33 & 1.16 & 12.38 & 8.00 & 10.00 & 10.00 \\
$40-60$ & 8.67 & 1.16 & 13.33 & 8.00 & 8.00 & 10.00 \\
$60-80$ & 8.00 & 1.73 & 21.63 & 7.00 & 7.00 & 10.00 \\
$80-100$ & 5.67 & 4.51 & 79.54 & 1.00 & 6.00 & 10.00 \\
\hline
\end{tabular}

Tabela C10.5: Alumínio na área A5

\begin{tabular}{ccccccc}
\hline \multicolumn{7}{c}{ Alumínio $\left(\mathrm{mmolc} / \mathrm{dm}^{3}\right)$} \\
\hline \multirow{2}{*}{ Profundidade $(\mathrm{cm})$} & Média & DP & CV & Mínimo & Mediana & Máximo \\
\cline { 2 - 7 } & 13.33 & 2.89 & 21.68 & 10.00 & 15.00 & 15.00 \\
$20-40$ & 10.33 & 0.58 & 5.58 & 10.00 & 10.00 & 11.00 \\
$40-60$ & 10.00 & 0.00 & 0.00 & 10.00 & 10.00 & 10.00 \\
$60-80$ & 10.00 & 1.00 & 10.00 & 9.00 & 10.00 & 11.00 \\
$80-100$ & 10.33 & 0.58 & 5.58 & 10.00 & 10.00 & 11.00 \\
\hline
\end{tabular}

Tabela C10.6: Alumínio na área A6

\begin{tabular}{ccccccc}
\hline \multicolumn{7}{c}{ Alumínio $\left(\mathrm{mmolc} / \mathrm{dm}^{3}\right)$} \\
\hline & \multicolumn{7}{c}{ A6 (sem vegetação) } \\
\cline { 2 - 7 } Profundidade $(\mathrm{cm})$ & Média & DP & CV & Mínimo & Mediana & Máximo \\
\hline $0-20$ & 7.00 & 1.73 & 24.71 & 6.00 & 6.00 & 9.00 \\
$20-40$ & 7.00 & 0.00 & 0.00 & 7.00 & 7.00 & 7.00 \\
$40-60$ & 6.33 & 0.58 & 9.11 & 6.00 & 6.00 & 7.00 \\
$60-80$ & 6.00 & 0.00 & 0.00 & 6.00 & 6.00 & 6.00 \\
$80-100$ & 6.33 & 0.58 & 9.11 & 6.00 & 6.00 & 7.00 \\
\hline
\end{tabular}

Tabela C11.1: Alumínio + Hidrogênio na área A1

\begin{tabular}{ccccccc}
\hline \multicolumn{7}{c}{ Hidrogênio + Alumínio $\left(\mathrm{mmolc} / \mathrm{dm}^{3}\right)$} \\
\hline \multirow{7}{*}{ Profundidade $(\mathrm{cm})$} & Média & DP & CV & Mínimo & Mediana & Máximo \\
\cline { 2 - 7 } & $56-70$ & 21.40 & 37.74 & 38.00 & 52.00 & 80.00 \\
$20-40$ & 60.00 & 19.10 & 31.83 & 42.00 & 58.00 & 80.00 \\
$40-60$ & 54.33 & 8.74 & 16.09 & 47.00 & 52.00 & 64.00 \\
$60-80$ & 53.33 & 13.61 & 25.52 & 38.00 & 58.00 & 64.00 \\
$80-100$ & 53.33 & 13.61 & 25.52 & 38.00 & 58.00 & 64.00 \\
\hline
\end{tabular}

Tabela C11.2: Alumínio + Hidrogênio na área $\mathrm{A} 2$

\begin{tabular}{ccccccc}
\hline \multicolumn{7}{c}{ Hidrogênio + Alumínio $\left(\mathrm{mmolc} / \mathrm{dm}^{3}\right)$} \\
\hline & Média & DP & CV & Mínimo & Mediana & Máximo \\
\cline { 2 - 7 } Profundidade $(\mathrm{cm})$ & 20.67 & 1.16 & 5.59 & 20.00 & 20.00 & 22.00 \\
$0-20$ & 22.33 & 2.52 & 11.29 & 20.00 & 22.00 & 25.00 \\
$20-40$ & 21.33 & 1.16 & 5.41 & 20.00 & 22.00 & 22.00 \\
$40-60$ & 11.00 & 3.61 & 32.82 & 8.00 & 10.00 & 15.00 \\
$60-80$ & 10.00 & 1.00 & 10.00 & 9.00 & 10.00 & 11.00 \\
$80-100$ & & & & & & \\
\hline
\end{tabular}


Tabela C11.3: Alumínio + Hidrogênio na área $\mathrm{A} 3$

\begin{tabular}{|c|c|c|c|c|c|c|}
\hline \multicolumn{7}{|c|}{ Hidrogênio + Alumínio $\left(\mathrm{mmolc} / \mathrm{dm}^{3}\right)$} \\
\hline \multirow[b]{2}{*}{ Profundidade $(\mathrm{cm})$} & \multicolumn{6}{|c|}{ A3 (8 anos) } \\
\hline & Média & DP & $\mathrm{CV}$ & Mínimo & Mediana & Máximo \\
\hline $0-20$ & 56.30 & 20.60 & 36.59 & 42.00 & 47.00 & 80.00 \\
\hline $20-40$ & 52.33 & 5.51 & 10.53 & 47.00 & 52.00 & 58.00 \\
\hline $40-60$ & 46.00 & 32.20 & 70.00 & 16.00 & 42.00 & 80.00 \\
\hline $60-80$ & 22.33 & 10.21 & 45.72 & 15.00 & 18.00 & 34.00 \\
\hline \multirow[t]{3}{*}{$80-100$} & 15.33 & 2.52 & 16.44 & 13.00 & 15.00 & 18.00 \\
\hline & \multicolumn{6}{|c|}{ Tabela C11.4: Alumínio + Hidrogênio na área A4 } \\
\hline & \multicolumn{5}{|c|}{ Hidrogênio + Alumínio $\left(\mathrm{mmolc} / \mathrm{dm}^{3}\right)$} & \\
\hline & \multicolumn{6}{|c|}{ A4 (6 anos) } \\
\hline Profundidade $(\mathrm{cm})$ & Média & DP & $\mathrm{CV}$ & Mínimo & Mediana & Máximo \\
\hline $0-20$ & 28.00 & 6.00 & 21.43 & 22.00 & 28.00 & 34.00 \\
\hline $20-40$ & 23.33 & 9.45 & 40.51 & 16.00 & 20.00 & 34.00 \\
\hline $40-60$ & 20.33 & 9.24 & 45.45 & 15.00 & 15.00 & 31.00 \\
\hline $60-80$ & 22.33 & 17.04 & 76.31 & 12.00 & 13.00 & 42.00 \\
\hline $80-100$ & 12.33 & 4.04 & 32.77 & 8.00 & 13.00 & 16.00 \\
\hline
\end{tabular}

Tabela C11.5: Alumínio + Hidrogênio na área A5

\begin{tabular}{|c|c|c|c|c|c|c|}
\hline \multicolumn{7}{|c|}{ Hidrogênio + Alumínio $\left(\mathrm{mmolc} / \mathrm{dm}^{3}\right)$} \\
\hline \multirow[b]{2}{*}{ Profundidade $(\mathrm{cm})$} & \multicolumn{6}{|c|}{ A5 (mata nativa) } \\
\hline & Média & DP & $\mathrm{CV}$ & Mínimo & Mediana & Máximo \\
\hline $0-20$ & 73.30 & 18.90 & 25.78 & 52.00 & 80.00 & 88.00 \\
\hline $20-40$ & 34.33 & 3.51 & 10.22 & 31.00 & 34.00 & 38.00 \\
\hline $40-60$ & 33.33 & 5.03 & 15.09 & 28.00 & 34.00 & 38.00 \\
\hline $60-80$ & 34.00 & 0.00 & 0.00 & 34.00 & 34.00 & 34.00 \\
\hline $80-100$ & 28.00 & 3.00 & 10.71 & 25.00 & 28.00 & 31.00 \\
\hline
\end{tabular}

Tabela C11.6: Alumínio + Hidrogênio na área A6

\begin{tabular}{ccccccc}
\hline \multicolumn{7}{c}{ Tabela C11.6: Alumínio + Hidrogênio na área A6 } \\
\hline \multicolumn{7}{c}{ Hidrogênio + Alumínio $\left(\mathrm{mmolc} / \mathrm{dm}^{3}\right)$} \\
\cline { 2 - 7 } Profundidade $(\mathrm{cm})$ & Média & DP & CV & Mínimo & Mediana & Máximo \\
\cline { 2 - 7 } $0-20$ & 19.67 & 4.73 & 24.05 & 16.00 & 18.00 & 25.00 \\
$20-40$ & 18.00 & 0.00 & 0.00 & 18.00 & 18.00 & 18.00 \\
$40-60$ & 17.33 & 1.16 & 6.66 & 16.00 & 18.00 & 18.00 \\
$60-80$ & 17.00 & 1.73 & 10.18 & 15.00 & 18.00 & 18.00 \\
$80-100$ & 16.33 & 3.51 & 21.49 & 13.00 & 16.00 & 20.00 \\
\hline
\end{tabular}

Tabela C12.1: Capacidade de Troca Catiônica (CTC) na área A1

\begin{tabular}{|c|c|c|c|c|c|c|}
\hline \multicolumn{7}{|c|}{ Capacidade de Troca Catiônica $\left(\mathrm{mmolc} / \mathrm{dm}^{3}\right)$} \\
\hline \multirow[b]{2}{*}{ Profundidade $(\mathrm{cm})$} & \multicolumn{6}{|c|}{ A1 (14 anos) } \\
\hline & Média & DP & $\mathrm{CV}$ & Mínimo & Mediana & Máximo \\
\hline $0-20$ & 66.70 & 21.30 & 31.93 & 47.60 & 62.70 & 89.70 \\
\hline $20-40$ & 62.30 & 19.10 & 30.66 & 44.20 & 60.30 & 82.30 \\
\hline $40-60$ & 56.93 & 8.34 & 14.65 & 50.30 & 54.20 & 66.30 \\
\hline $60-80$ & 55.57 & 13.63 & 24.53 & 40.20 & 60.30 & 66.20 \\
\hline $80-100$ & 55.53 & 13.61 & 24.51 & 40.20 & 60.20 & 66.20 \\
\hline
\end{tabular}


Tabela C12.2: Capacidade de Troca Catiônica (CTC) na área A2

\begin{tabular}{ccccccc}
\hline \multicolumn{7}{c}{ Capacidade de Troca Catiônica $\left(\mathrm{mmolc} / \mathrm{dm}^{3}\right)$} \\
\hline & Média & DP & CV & Mínimo & Mediana & Máximo \\
\cline { 2 - 7 } Profundidade $(\mathrm{cm})$ & 32.87 & 2.27 & 6.91 & 30.30 & 33.70 & 34.60 \\
$0-20$ & 25.10 & 2.00 & 7.97 & 23.10 & 25.10 & 27.10 \\
$20-40$ & 23.77 & 1.53 & 6.43 & 22.10 & 24.10 & 25.10 \\
$40-60$ & 16.10 & 5.20 & 32.30 & 13.10 & 13.10 & 22.10 \\
$60-80$ & 15.10 & 2.65 & 17.55 & 12.10 & 16.10 & 17.10 \\
\hline $80-100$ & & & & & & \\
\hline
\end{tabular}

Tabela C12.3: Capacidade de Troca Catiônica (CTC) na área A3

\begin{tabular}{ccccccc}
\hline \multicolumn{7}{c}{ Capacidade de Troca Catiônica $\left(\mathrm{mmolc} / \mathrm{dm}^{3}\right)$} \\
\hline & \multicolumn{7}{c}{ A3 (8 anos) } \\
\cline { 2 - 7 } Profundidade $(\mathrm{cm})$ & Média & DP & CV & Mínimo & Mediana & Máximo \\
\hline $0-20$ & 68.93 & 16.44 & 23.85 & 56.60 & 62.60 & 87.60 \\
$20-40$ & 55.20 & 5.57 & 10.09 & 50.20 & 54.20 & 61.20 \\
$40-60$ & 48.50 & 32.70 & 67.42 & 18.20 & 44.20 & 83.20 \\
$60-80$ & 24.47 & 10.18 & 41.60 & 17.20 & 20.10 & 36.10 \\
$80-100$ & 17.77 & 3.06 & 17.22 & 15.10 & 17.10 & 21.10 \\
\hline
\end{tabular}

Tabela C12.4: Capacidade de Troca Catiônica (CTC) na área A4

\begin{tabular}{|c|c|c|c|c|c|c|}
\hline \multicolumn{7}{|c|}{ Capacidade de Troca Catiônica $\left(\mathrm{mmolc} / \mathrm{dm}^{3}\right)$} \\
\hline \multirow[b]{2}{*}{ Profundidade $(\mathrm{cm})$} & \multicolumn{6}{|c|}{ A4 (6 anos) } \\
\hline & Média & DP & $\mathrm{CV}$ & Mínimo & Mediana & Máximo \\
\hline $0-20$ & 52.80 & 14.89 & 28.20 & 39.70 & 49.70 & 69.00 \\
\hline $20-40$ & 27.13 & 8.78 & 32.36 & 21.10 & 23.10 & 37.20 \\
\hline $40-60$ & 22.77 & 8.96 & 39.35 & 17.10 & 18.10 & 33.10 \\
\hline $60-80$ & 24.80 & 17.60 & 70.97 & 14.10 & 15.10 & 45.10 \\
\hline $80-100$ & 16.77 & 5.86 & 34.94 & 10.10 & 19.10 & 21.10 \\
\hline
\end{tabular}

Tabela C12.5: Capacidade de Troca Catiônica (CTC) na área A5

\begin{tabular}{ccccccc}
\hline \multicolumn{7}{c}{ Capacidade de Troca Catiônica $\left(\mathrm{mmolc} / \mathrm{dm}^{3}\right)$} \\
\hline & \multicolumn{7}{c}{ A5 (mata nativa) } \\
\cline { 2 - 7 } Profundidade $(\mathrm{cm})$ & Média & DP & CV & Mínimo & Mediana & Máximo \\
\hline $0-20$ & 76.30 & 19.10 & 25.03 & 54.60 & 83.60 & 90.70 \\
$20-40$ & 36.57 & 3.52 & 9.63 & 33.30 & 36.10 & 40.30 \\
$40-60$ & 35.43 & 5.03 & 14.20 & 30.10 & 36.10 & 40.10 \\
$60-80$ & 36.77 & 1.16 & 3.14 & 36.10 & 36.10 & 38.10 \\
$80-100$ & 30.10 & 3.00 & 9.97 & 27.10 & 30.10 & 33.10 \\
\hline
\end{tabular}

Tabela C12.6: Capacidade de Troca Catiônica (CTC) na área A6

\begin{tabular}{ccccccc}
\hline \multicolumn{7}{c}{ Capacidade de Troca Catiônica $\left(\mathrm{mmolc} / \mathrm{dm}^{3}\right)$} \\
\hline & \multicolumn{7}{c}{ A6 (sem vegetação) } \\
\cline { 2 - 7 } Profundidade $(\mathrm{cm})$ & Média & DP & CV & Mínimo & Mediana & Máximo \\
\hline $0-20$ & 21.77 & 4.73 & 21.73 & 18.10 & 20.10 & 27.10 \\
$20-40$ & 20.10 & 0.00 & 0.00 & 20.10 & 20.10 & 20.10 \\
$40-60$ & 20.47 & 2.57 & 12.55 & 18.10 & 20.10 & 23.20 \\
$60-80$ & 19.43 & 1.16 & 5.94 & 18.10 & 20.10 & 20.10 \\
$80-100$ & 21.47 & 3.07 & 14.30 & 18.10 & 22.20 & 24.10 \\
\hline
\end{tabular}


Tabela C13.1: V - Porcentagem de Saturação de Bases na área A1

\begin{tabular}{ccccccc}
\hline \multicolumn{7}{c}{ V - Porcentagem de Saturação de Bases (\%) } \\
\hline & \multicolumn{7}{c}{ A1 (14 anos) } \\
\cline { 2 - 7 } Profundidade $(\mathrm{cm})$ & Média & DP & CV & Mínimo & Mediana & Máximo \\
\hline $0-20$ & 16.00 & 4.58 & 28.63 & 11.00 & 17.00 & 20.00 \\
$20-40$ & 4.00 & 1.00 & 25.00 & 3.00 & 4.00 & 5.00 \\
$40-60$ & 4.67 & 2.08 & 44.54 & 3.00 & 4.00 & 7.00 \\
$60-80$ & 4.00 & 1.00 & 25.00 & 3.00 & 4.00 & 5.00 \\
$80-100$ & 4.00 & 1.00 & 25.00 & 3.00 & 4.00 & 5.00 \\
\hline
\end{tabular}

Tabela C13.2: V - Porcentagem de Saturação de Bases na área A2

\begin{tabular}{|c|c|c|c|c|c|c|}
\hline \multicolumn{7}{|c|}{ V - Porcentagem de Saturação de Bases (\%) } \\
\hline \multirow[b]{2}{*}{ Profundidade $(\mathrm{cm})$} & \multicolumn{6}{|c|}{ A2 (11 anos) } \\
\hline & Média & DP & $\mathrm{CV}$ & Mínimo & Mediana & Máximo \\
\hline $0-20$ & 37.00 & 4.36 & 11.78 & 34.00 & 35.00 & 42.00 \\
\hline $20-40$ & 11.00 & 2.65 & 24.09 & 8.00 & 12.00 & 13.00 \\
\hline $40-60$ & 10.33 & 1.53 & 14.79 & 9.00 & 10.00 & 12.00 \\
\hline $60-80$ & 31.67 & 7.51 & 23.71 & 24.00 & 32.00 & 39.00 \\
\hline $80-100$ & 33.33 & 6.43 & 19.29 & 26.00 & 36.00 & 38.00 \\
\hline
\end{tabular}

Tabela C13.3: V - Porcentagem de Saturação de Bases na área A3

\begin{tabular}{|c|c|c|c|c|c|c|}
\hline \multicolumn{7}{|c|}{ V - Porcentagem de Saturação de Bases (\%) } \\
\hline \multirow[b]{2}{*}{ Profundidade $(\mathrm{cm})$} & \multicolumn{6}{|c|}{ A3 (8 anos) } \\
\hline & Média & DP & $\mathrm{CV}$ & Mínimo & Mediana & Máximo \\
\hline $0-20$ & 19.67 & 12.22 & 62.13 & 9.00 & 17.00 & 33.00 \\
\hline $20-40$ & 5.00 & 1.00 & 20.00 & 4.00 & 5.00 & 6.00 \\
\hline $40-60$ & 7.00 & 4.36 & 62.29 & 4.00 & 5.00 & 12.00 \\
\hline $60-80$ & 9.67 & 3.51 & 36.30 & 6.00 & 10.00 & 13.00 \\
\hline $80-100$ & 13.67 & 1.53 & 11.18 & 12.00 & 14.00 & 15.00 \\
\hline
\end{tabular}

Tabela C13.4: V - Porcentagem de Saturação de Bases na área A4

\begin{tabular}{|c|c|c|c|c|c|c|}
\hline \multicolumn{7}{|c|}{ V - Porcentagem de Saturação de Bases (\%) } \\
\hline \multirow[b]{2}{*}{ Profundidade $(\mathrm{cm})$} & \multicolumn{6}{|c|}{ A4 (6 anos) } \\
\hline & Média & DP & $\mathrm{CV}$ & Mínimo & Mediana & Máximo \\
\hline $0-20$ & 43.00 & 21.70 & 50.47 & 29.00 & 32.00 & 68.00 \\
\hline $20-40$ & 15.33 & 7.77 & 50.68 & 9.00 & 13.00 & 24.00 \\
\hline $40-60$ & 11.67 & 5.51 & 47.22 & 6.00 & 12.00 & 17.00 \\
\hline $60-80$ & 12.00 & 4.36 & 36.33 & 7.00 & 14.00 & 15.00 \\
\hline $80-100$ & 25.00 & 11.53 & 46.12 & 16.00 & 21.00 & 38.00 \\
\hline
\end{tabular}

Tabela C13.5: V - Porcentagem de Saturação de Bases na área A5 V - Porcentagem de Saturação de Bases (\%)

\begin{tabular}{ccccccc}
\hline \multicolumn{7}{c}{ V - Porcentagem de Saturação de Bases (\%) } \\
\hline & \multicolumn{7}{c}{ A5 (mata nativa) } \\
\cline { 2 - 7 } Profundidade (cm) & Média & DP & CV & Mínimo & Mediana & Máximo \\
\hline $0-20$ & 4.00 & 1.00 & 25.00 & 3.00 & 4.00 & 5.00 \\
$20-40$ & 6.33 & 0.58 & 9.11 & 6.00 & 6.00 & 7.00 \\
$40-60$ & 6.00 & 1.00 & 16.67 & 5.00 & 6.00 & 7.00 \\
$60-80$ & 7.67 & 2.89 & 37.68 & 6.00 & 6.00 & 11.00 \\
$80-100$ & 7.00 & 1.00 & 14.29 & 6.00 & 7.00 & 8.00 \\
\hline
\end{tabular}


Tabela C13.6: V - Porcentagem de Saturação de Bases na área A6

\begin{tabular}{ccccccc}
\hline \multicolumn{7}{c}{ V - Porcentagem de Saturação de Bases (\%) } \\
\cline { 2 - 7 } Profundidade (cm) & Média & DP & CV & Mínimo & Mediana & Máximo \\
\hline $0-20$ & 10.00 & 2.00 & 20.00 & 8.00 & 10.00 & 12.00 \\
$20-40$ & 10.00 & 0.00 & 0.00 & 10.00 & 10.00 & 10.00 \\
$40-60$ & 14.67 & 6.43 & 43.83 & 10.00 & 12.00 & 22.00 \\
$60-80$ & 12.33 & 4.04 & 32.77 & 10.00 & 10.00 & 17.00 \\
$80-100$ & 22.70 & 20.20 & 88.99 & 10.00 & 12.00 & 46.00 \\
\hline
\end{tabular}


APÊNDICE C: PERFIS MÉDIOS DAS VARIÁVEIS DO SUBSTRATO 
Gráfico D1: Perfis médios de densidade

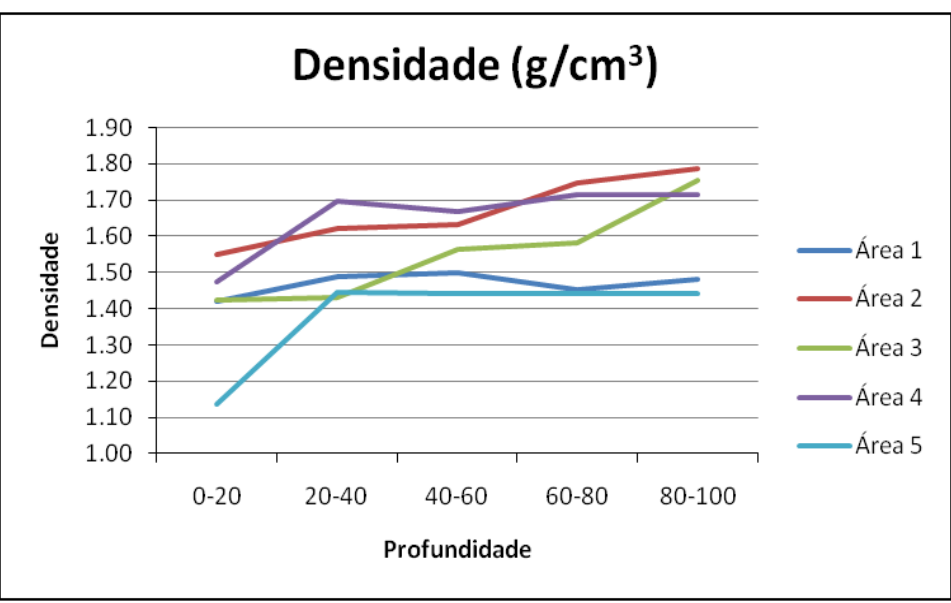

Gráfico D2: Perfis médios de porosidade

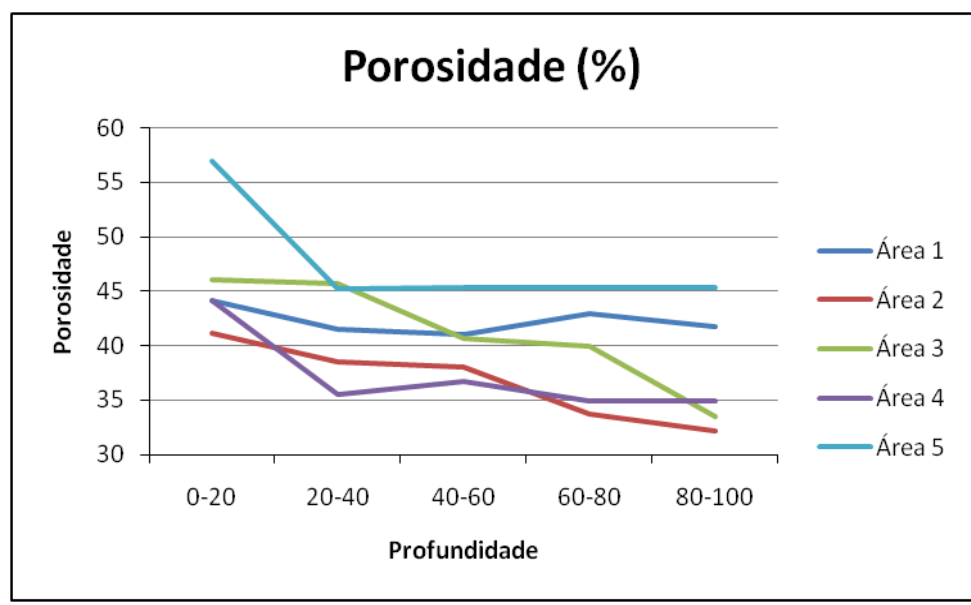

Gráfico D3: Perfis médios de $\mathrm{pH}$

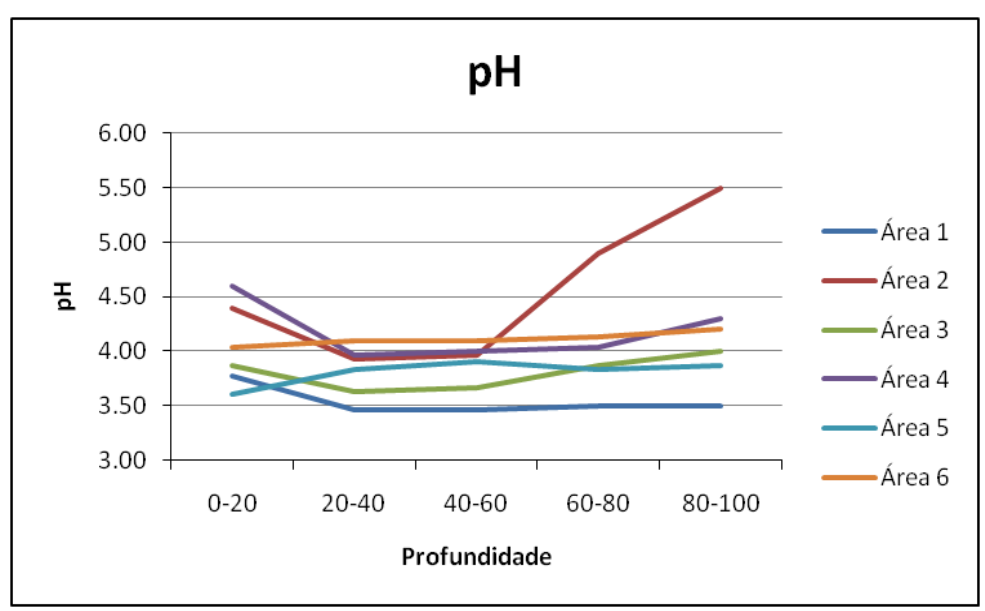


Gráfico D4: Perfis médios de matéria orgânica

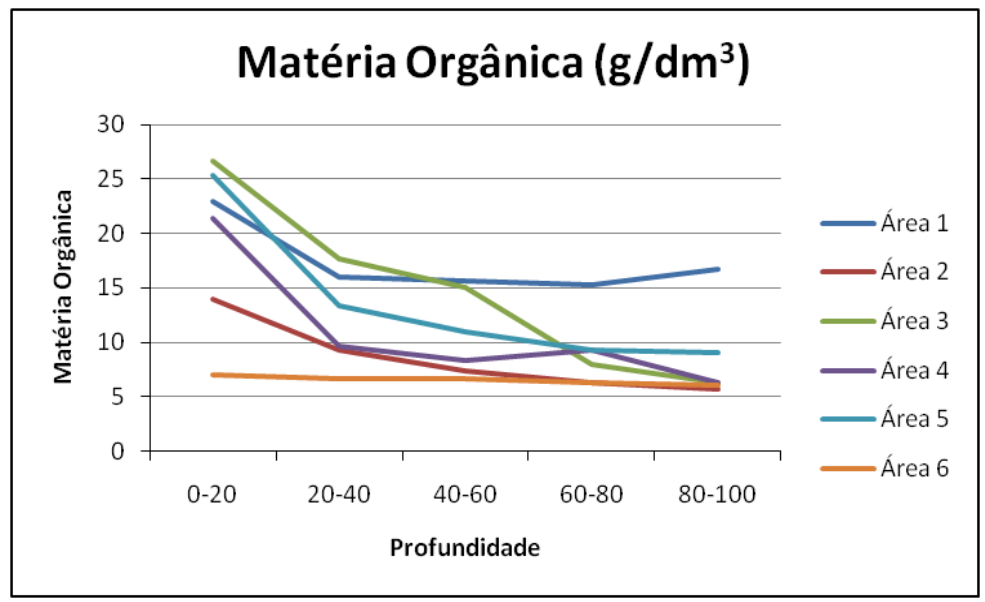

Gráfico D5: Perfis médios de fósforo

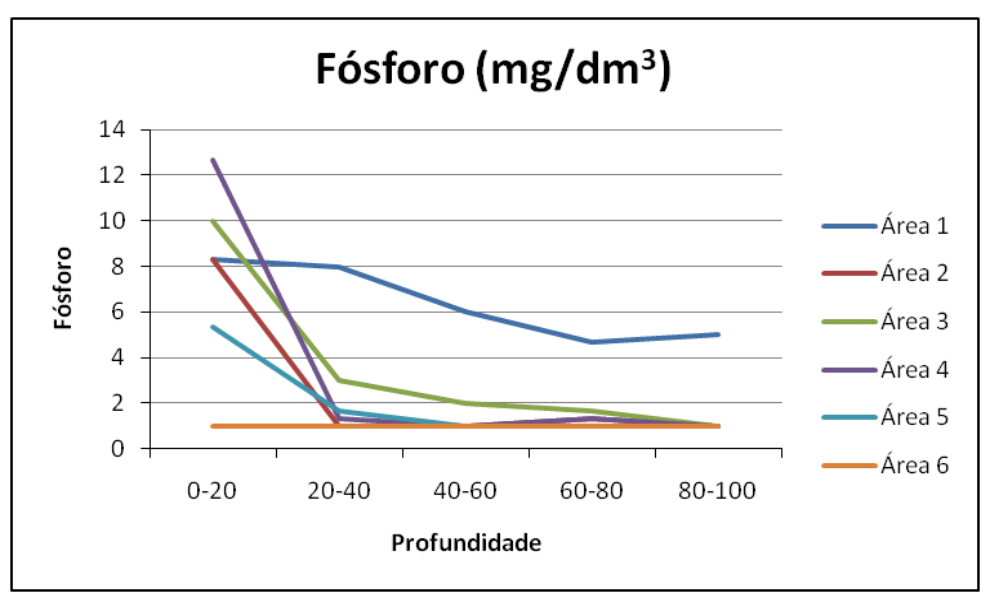

Gráfico D6: Perfis médios potássio

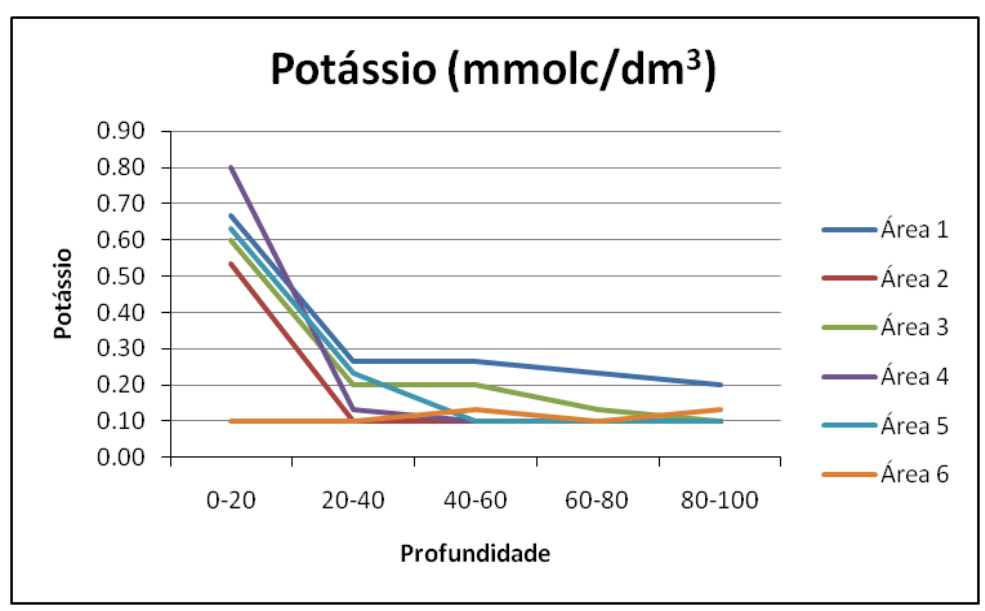


Gráfico D7: Perfis médios de cálcio

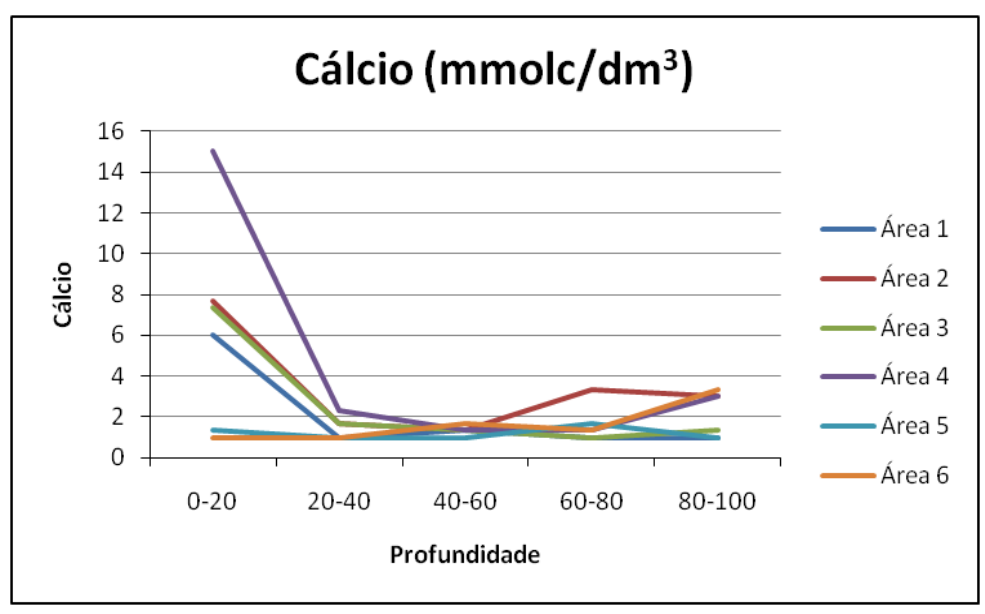

Gráfico D8: Perfis médios de magnésio

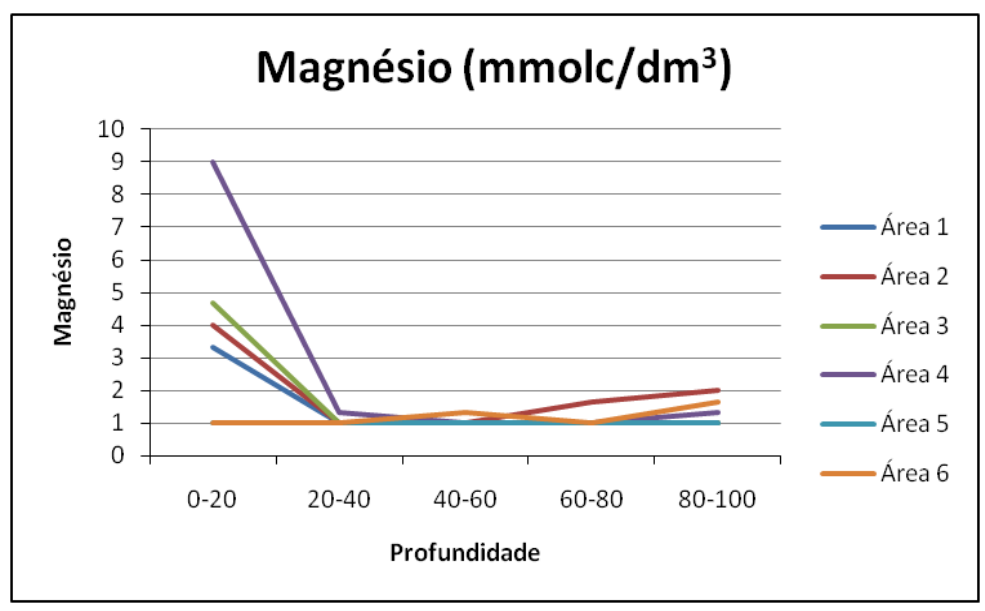

Gráfico D9: Perfis médios de soma de bases

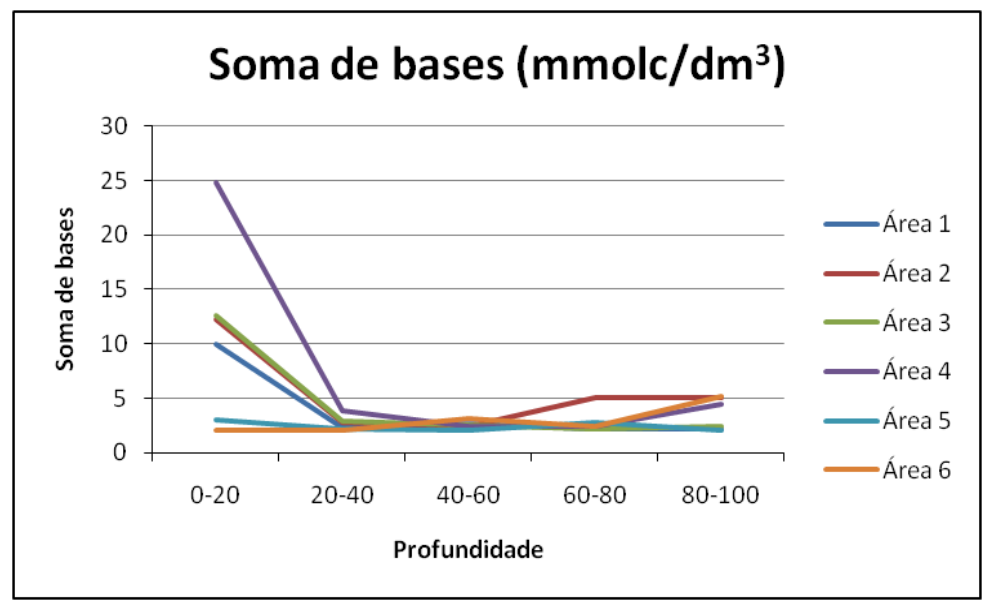


Gráfico D10: Perfis médios de capacidade de troca catiônica

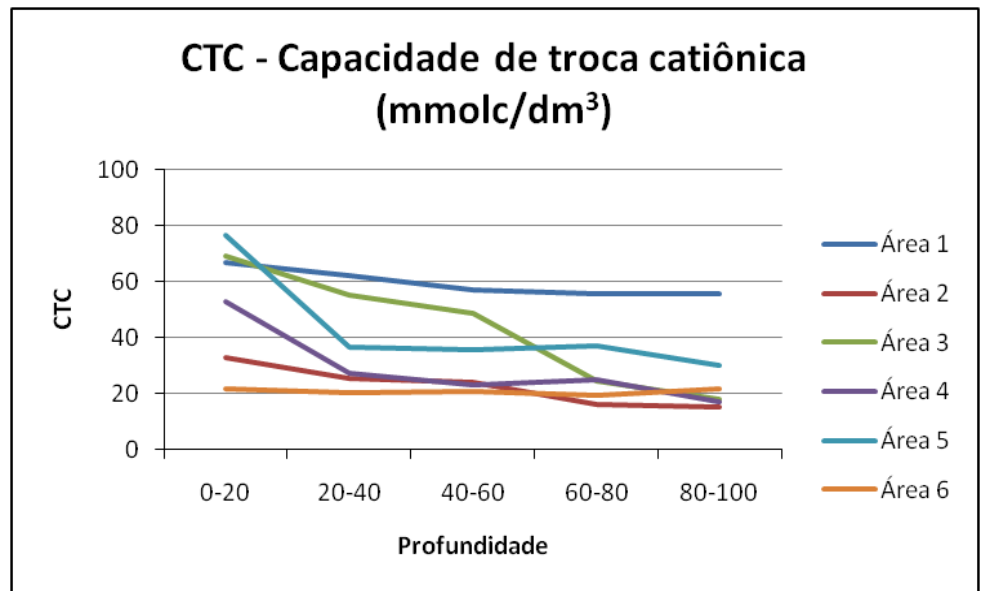

Gráfico D11: Perfis médios de alumínio

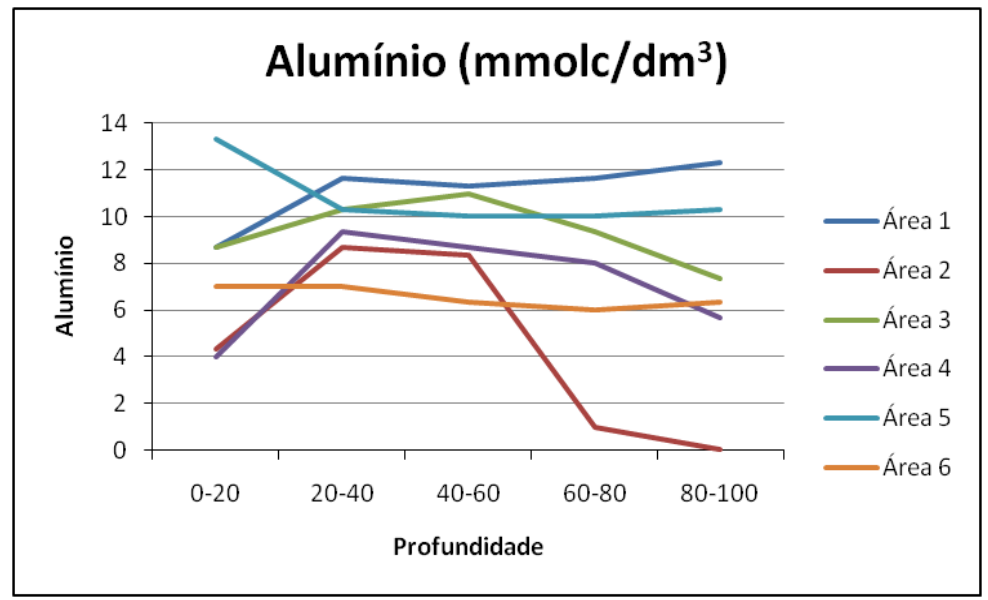

Gráfico D12: Perfis médios de hidrogênio + alumínio

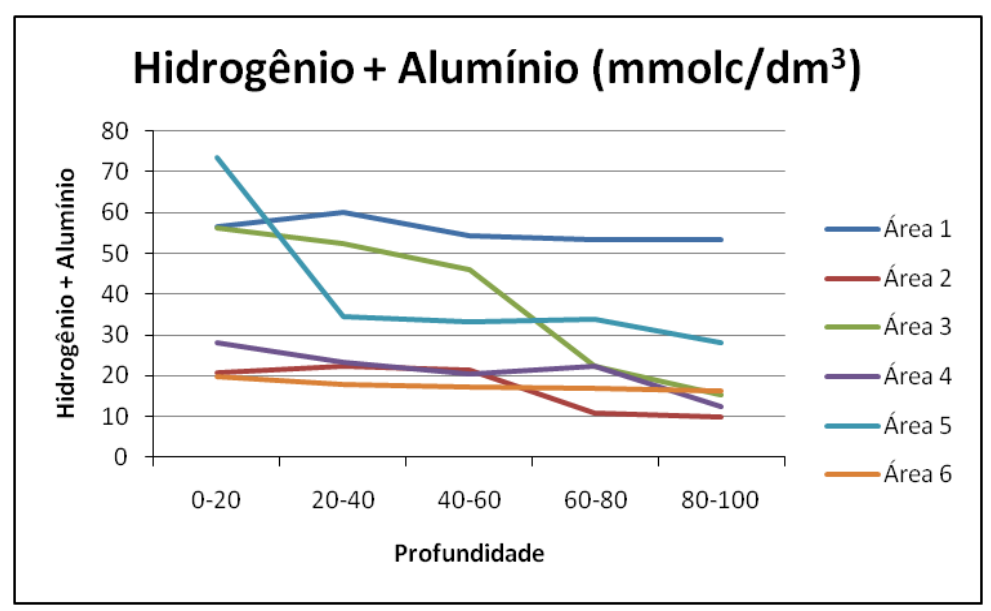


Gráfico D13: Perfis médios de porcentagem de saturação de bases

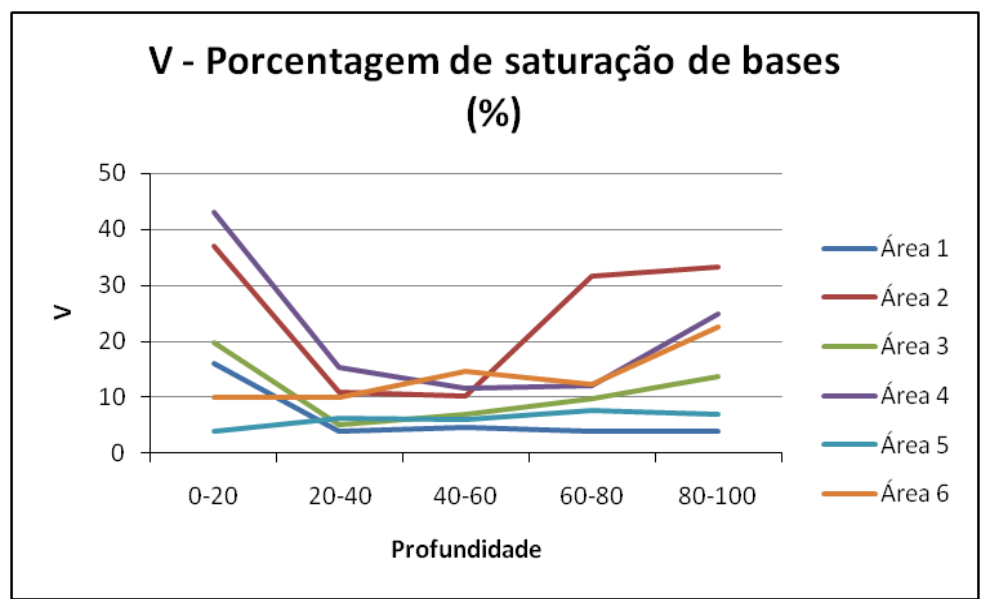


APÊNDICE D: ANÁLISES GRANULOMÉTRICAS DO SUBSTRATO 
Tabela B1: Resultados das análises granulométricas dos substratos das áreas de estudo

\begin{tabular}{|c|c|c|c|c|c|c|}
\hline Área & Camada & Amostra & Argila \% & Silte \% & Areia \% & Dp \\
\hline A1 & $0-20$ & 6 & 7,8 & 5,0 & 87,3 & 2,6 \\
\hline $\mathrm{A} 1$ & $0-20$ & 11 & 9,8 & 0,7 & 89,5 & 2,5 \\
\hline $\mathrm{A} 2$ & $0-20$ & 16 & 5,6 & 4,5 & 89,9 & 2,6 \\
\hline $\mathrm{A} 3$ & $0-20$ & 41 & 4,6 & 4,8 & 90,6 & 2,6 \\
\hline A4 & $0-20$ & 51 & 3,4 & 3,4 & 93,2 & 2,6 \\
\hline A5 & $0-20$ & 66 & 5,5 & 2,7 & 91,8 & 2,6 \\
\hline A6 & $0-20$ & 76 & 4,2 & 3,0 & 92,8 & 2,6 \\
\hline $\mathrm{A} 1$ & $20-40$ & 7 & 8,5 & 0,5 & 91,0 & 2,5 \\
\hline $\mathrm{A} 1$ & $20-40$ & 12 & 10,4 & 1,6 & 88,1 & 2,4 \\
\hline $\mathrm{A} 3$ & $20-40$ & 32 & 5,9 & 3,8 & 90,4 & 2,6 \\
\hline A4 & $20-40$ & 57 & 6,2 & 2,7 & 91,1 & 2,6 \\
\hline A5 & $40-60$ & 72 & 3,6 & 4,3 & 92,1 & 2,6 \\
\hline A6 & $20-40$ & 87 & 2,0 & 4,4 & 93,7 & 2,6 \\
\hline $\mathrm{A} 1$ & $40-60$ & 8 & 7,9 & 0,3 & 91,9 & 2,4 \\
\hline $\mathrm{A} 1$ & $40-60$ & 13 & 8,4 & 2,7 & 88,9 & 2,5 \\
\hline $\mathrm{A} 2$ & $40-60$ & 28 & 6,4 & 2,9 & 90,7 & 2,7 \\
\hline $\mathrm{A} 3$ & $40-60$ & 38 & 6,6 & 3,6 & 89,9 & 2,6 \\
\hline A4 & $40-60$ & 48 & 6,6 & 3,0 & 90,4 & 2,6 \\
\hline A5 & $40-60$ & 63 & 7,7 & 4,7 & 87,6 & 2,6 \\
\hline A6 & $40-60$ & 83 & 3,6 & 5,2 & 91,2 & 2,6 \\
\hline $\mathrm{A} 1$ & $60-80$ & 9 & 7,8 & 1,7 & 90,6 & 2,6 \\
\hline $\mathrm{A} 1$ & $60-80$ & 14 & 11,8 & 1,6 & 86,6 & 2,5 \\
\hline $\mathrm{A} 2$ & $60-80$ & 24 & 1,5 & 1,7 & 96,8 & 2,7 \\
\hline $\mathrm{A} 3$ & $60-80$ & 44 & 5,4 & 5,7 & 88,9 & 2,7 \\
\hline A4 & $60-80$ & 54 & 8,4 & 4,3 & 87,2 & 2,6 \\
\hline A5 & $60-80$ & 69 & 9,7 & 5,3 & 85,1 & 2,6 \\
\hline A6 & $60-80$ & 89 & 5,1 & 4,6 & 90,2 & 2,6 \\
\hline $\mathrm{A} 1$ & $80-100$ & 5 & 11,4 & 1,9 & 86,7 & 2,3 \\
\hline $\mathrm{A} 1$ & $80-100$ & 10 & 8,1 & 1,2 & 90,7 & 2,6 \\
\hline $\mathrm{A} 2$ & $80-100$ & 20 & 4,8 & 3,7 & 91,5 & 2,7 \\
\hline $\mathrm{A} 3$ & $80-100$ & 35 & 8,1 & 1,1 & 90,8 & 2,7 \\
\hline A4 & $80-100$ & 60 & 8,3 & 3,1 & 88,6 & 2,7 \\
\hline A5 & $80-100$ & 75 & 8,7 & 2,6 & 88,7 & 2,6 \\
\hline Rejeito & & 200 & 4,5 & 88,6 & 7,0 & 2,7 \\
\hline
\end{tabular}


APÊNDICE E: MEDIDAS RESUMO DAS VARIÁVEIS DE VEGETAÇÃO 
Tabela E1.1: CAP na área 1

\begin{tabular}{|c|c|c|c|c|c|c|c|}
\hline \multicolumn{8}{|c|}{ CAP - Circunferência à Altura do Peito $(\mathrm{cm})$} \\
\hline \multirow{2}{*}{ Vegetação } & \multicolumn{7}{|c|}{ Área 1 (14 anos) } \\
\hline & Média & Mínimo & Máximo & 1o Quartil & Mediana & 3o Quartil & DP \\
\hline Peltophorum dubium & 20,83 & 8,00 & 37,00 & 13,25 & 16,00 & 34,00 & 11,46 \\
\hline Schinus terebentifolius & 20,80 & 16,00 & 28,00 & 18,00 & 20,00 & 24,00 & 4,38 \\
\hline Acacia polyphilla & 39,43 & 20,00 & 68,00 & 24,75 & 39,00 & 47,25 & 14,75 \\
\hline Lafoensia pacari & 17,00 & 16,00 & 20,00 & 16,00 & 16,00 & 19,00 & 2,00 \\
\hline Psidium guajaba & 11,63 & 5,00 & 18,00 & 6,25 & 11,00 & 17,75 & 5,55 \\
\hline $\begin{array}{l}\text { Inga edulis } \\
\text { Enterolobium }\end{array}$ & 15,67 & 5,00 & 32,00 & 5,00 & 10,00 & 32,00 & 14,36 \\
\hline contortisiliquит & - & - & - & 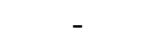 & 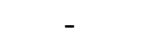 & . & 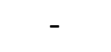 \\
\hline Psudobombax manguba & 17,94 & 6,00 & 30,00 & 10,00 & 19,00 & 24,25 & 7,78 \\
\hline Jacaranda micrantha & 14,35 & 5,00 & 37,00 & 5,00 & 12,50 & 21,50 & 8,96 \\
\hline Croton floribundus & 26,90 & 5,00 & 57,00 & 5,75 & 25,50 & 46,00 & 20,27 \\
\hline Hymenaea stigonocarpa & 14,50 & 13,00 & 16,00 & 13,25 & 14,50 & 15,75 & 1,29 \\
\hline Inga uruguensis & 18,67 & 5,00 & 34,00 & 5,00 & 17,00 & 34,00 & 14,57 \\
\hline Pterogiyne nitens & 27,50 & 27,00 & 28,00 & 27,25 & 27,50 & 27,75 & 0,71 \\
\hline Luehea paniculata & 8,00 & 8,00 & 8,00 & 8,00 & 8,00 & 8,00 & - \\
\hline Tabebuia cassineoides & 18,00 & 5,00 & 40,00 & 5,00 & 9,00 & 40,00 & 19,16 \\
\hline Nectandra cuspidata & - & - & - & - & - & - & - \\
\hline Copaifera langsdorffii & - & - & - & - & - & - & - \\
\hline Mollinedia schottiana & - & - & - & - & - & - & - \\
\hline Tapirira guianensis & - & - & - & - & - & - & - \\
\hline Xylopia aromatica & - & - & - & - & - & - & - \\
\hline Rapanea umbellata & - & - & - & - & - & - & - \\
\hline Outras & 22,66 & 6,00 & 77,00 & 11,25 & 18,00 & 30,00 & 15,56 \\
\hline
\end{tabular}


Tabela E1.2: CAP na área 2

\begin{tabular}{|c|c|c|c|c|c|c|c|}
\hline \multicolumn{8}{|c|}{ CAP - Circunferência à Altura do Peito $(\mathrm{cm})$} \\
\hline \multirow{2}{*}{ Vegetação } & \multicolumn{7}{|c|}{ Área 2 (11 anos) } \\
\hline & Média & Mínimo & Máximo & 1o Quartil & Mediana & 3o Quartil & DP \\
\hline Peltophorum dubium & 17,17 & 8,00 & 29,00 & 9,50 & 15,00 & 26,75 & 8,89 \\
\hline Schinus terebentifolius & 11,86 & 5,00 & 21,00 & 8,00 & 10,00 & 19,00 & 5,90 \\
\hline Acacia polyphilla & 9,79 & 5,00 & 22,00 & 6,00 & 7,00 & 13,00 & 5,97 \\
\hline Lafoensia pacari & 12,43 & 6,00 & 21,00 & 7,00 & 12,00 & 16,00 & 5,32 \\
\hline Psidium guajaba & 14,60 & 10,00 & 18,00 & 12,00 & 14,00 & 17,50 & 3,13 \\
\hline $\begin{array}{l}\text { Inga edulis } \\
\text { Enterolobium }\end{array}$ & 10,33 & 6,00 & 13,00 & 6,00 & 12,00 & 13,00 & 3,79 \\
\hline contortisiliquum & 34,38 & 18,00 & 52,00 & 23,25 & 34,50 & 42,75 & 11,43 \\
\hline Psudobombax manguba & 11,90 & 5,00 & 29,00 & 8,25 & 11,00 & 12,50 & 6,61 \\
\hline Jacaranda micrantha & 5,00 & 5,00 & 5,00 & 5,00 & 5,00 & 5,00 & - \\
\hline Croton floribundus & 15,93 & 5,00 & 33,00 & 9,00 & 12,50 & 26,50 & 9,50 \\
\hline Hymenaea stigonocarpa & 6,33 & 5,00 & 7,00 & 5,00 & 7,00 & 7,00 & 1,15 \\
\hline Inga uruguensis & 14,50 & 9,00 & 26,00 & 9,00 & 11,50 & 23,00 & 8,02 \\
\hline Pterogiyne nitens & - & - & - & - & - & - & - \\
\hline Luehea paniculata & 7,67 & 7,00 & 8,00 & 7,00 & 8,00 & 8,00 & 0,58 \\
\hline Tabebuia cassineoides & 6,00 & 6,00 & 6,00 & 6,00 & 6,00 & 6,00 & - \\
\hline Nectandra cuspidata & - & - & - & - & - & - & - \\
\hline Copaifera langsdorffii & - & - & - & - & - & - & - \\
\hline Mollinedia schottiana & - & - & - & - & - & - & - \\
\hline Tapirira guianensis & - & - & - & - & - & - & - \\
\hline Xylopia aromatica & - & - & - & - & - & - & - \\
\hline Rapanea umbellata & - & - & - & - & - & - & - \\
\hline Outras & 19,38 & 5,00 & 82,00 & 7,25 & 13,50 & 24,75 & 17,82 \\
\hline
\end{tabular}


Tabela E1.3: CAP na área 3

\begin{tabular}{lccccccc}
\hline \multicolumn{7}{c}{ CAP - Circunferência à Altura do Peito (cm) } \\
\cline { 2 - 8 } \multicolumn{1}{c}{ Vegetação } & Média & Mínimo & Máximo & 1 o Quartil & Mediana & 30 Quartil & DP \\
\cline { 2 - 8 } & 22,25 & 7,00 & 62,00 & 12,00 & 16,00 & 31,00 & 13,93 \\
\hline Peltophorum dubium & 17,26 & 8,00 & 39,00 & 11,00 & 17,00 & 21,00 & 6,70 \\
Schinus terebentifolius & 34,63 & 19,00 & 54,00 & 24,00 & 32,50 & 46,75 & 12,69 \\
Acacia polyphilla & 13,03 & 5,00 & 20,00 & 10,50 & 13,00 & 15,50 & 3,85 \\
Lafoensia pacari & 11,14 & 8,00 & 17,00 & 9,00 & 9,00 & 16,00 & 3,72 \\
Psidium guajaba & 21,00 & 7,00 & 34,00 & 18,00 & 20,00 & 26,00 & 7,54 \\
Inga edulis & & & & & & \\
Enterolobium & 38,50 & 16,00 & 64,00 & 31,75 & 40,00 & 43,25 & 12,55 \\
contortisiliquum & 20,00 & 16,00 & 27,00 & 16,00 & 17,00 & 27,00 & 6,08 \\
Psudobombax manguba & 10,00 & 10,00 & 10,00 & 10,00 & 10,00 & 10,00 & - \\
Jacaranda micrantha & 15,00 & 15,00 & 15,00 & 15,00 & 15,00 & 15,00 & - \\
Croton floribundus & 10,50 & 5,00 & 23,00 & 6,25 & 10,00 & 11,75 & 5,63 \\
Hymenaea stigonocarpa & 28,67 & 25,00 & 33,00 & 25,00 & 28,00 & 33,00 & 4,04 \\
Inga uruguensis & 9,83 & 6,00 & 13,00 & 7,50 & 10,00 & 12,25 & 2,56 \\
Pterogiyne nitens & 15,00 & 11,00 & 19,00 & 13,00 & 15,00 & 17,00 & 5,66 \\
Luehea paniculata & 9,00 & 9,00 & 9,00 & 9,00 & 9,00 & 9,00 & - \\
Tabebuia cassineoides & - & - & - & - & - & - & - \\
Nectandra cuspidata & - & - & 7,00 & \\
Copaifera langsdorffii & 11,00 & 6,00 & 16,00 & 8,50 & 11,00 & 13,50 & 7,07 \\
Mollinedia schottiana & 7,00 & 7,00 & 7,00 & 7,00 & 7,00 & 7,00 & - \\
Tapirira guianensis & - & - & - & - & - & - & - \\
Xylopia aromatica & - & - & - & - & - & - & - \\
Rapanea umbellata & - & - & - & - & - & - & - \\
Outras & 19,00 & 5,00 & 85,00 & 10,00 & 16,00 & 23,00 & 15,58 \\
\hline
\end{tabular}


Tabela E1.4: CAP na área 4

\begin{tabular}{|c|c|c|c|c|c|c|c|}
\hline \multicolumn{8}{|c|}{ CAP - Circunferência á Altura do Peito (cm) } \\
\hline \multirow{2}{*}{ Vegetação } & \multicolumn{7}{|c|}{ Área 4 (6 anos) } \\
\hline & Média & Mínimo & Máximo & 1o Quartil & Mediana & 3o Quartil & DP \\
\hline Peltophorum dubium & 16,45 & 5,00 & 33,00 & 10,25 & 14,50 & 20,75 & 8,23 \\
\hline Schinus terebentifolius & 13,70 & 5,00 & 28,00 & 10,00 & 13,50 & 17,00 & 6,15 \\
\hline Acacia polyphilla & 17,69 & 5,00 & 45,00 & 7,50 & 11,00 & 30,00 & 14,32 \\
\hline Lafoensia pacari & 8,29 & 5,00 & 15,00 & 6,00 & 7,50 & 10,00 & 2,89 \\
\hline Psidium guajaba & 9,25 & 5,00 & 15,00 & 5,75 & 10,00 & 11,25 & 3,14 \\
\hline $\begin{array}{l}\text { Inga edulis } \\
\text { Enterolobium }\end{array}$ & 19,50 & 18,00 & 23,00 & 18,00 & 18,50 & 22,00 & 2,38 \\
\hline contortisiliquum & 33,27 & 6,00 & 58,00 & 21,00 & 35,00 & 46,00 & 16,13 \\
\hline Psudobombax manguba & 9,00 & 9,00 & 9,00 & 9,00 & 9,00 & 9,00 & - \\
\hline Jacaranda micrantha & 18,00 & 18,00 & 18,00 & 18,00 & 18,00 & 18,00 & - \\
\hline Croton floribundus & - & - & - & - & - & - & - \\
\hline Hymenaea stigonocarpa & - & - & - & - & - & - & - \\
\hline Inga uruguensis & 7,40 & 5,00 & 16,00 & 5,00 & 5,00 & 11,00 & 4,83 \\
\hline Pterogiyne nitens & 8,00 & 8,00 & 8,00 & 8,00 & 8,00 & 8,00 & - \\
\hline Luehea paniculata & 10,67 & 6,00 & 14,00 & 6,00 & 12,00 & 14,00 & 4,16 \\
\hline Tabebuia cassineoides & 9,33 & 5,00 & 12,00 & 5,00 & 11,00 & 12,00 & 3,79 \\
\hline Nectandra cuspidata & - & - & - & - & - & - & - \\
\hline Copaifera langsdorffii & - & - & - & - & - & - & - \\
\hline Mollinedia schottiana & - & - & - & - & - & - & - \\
\hline Tapirira guianensis & 13,00 & 13,00 & 13,00 & 13,00 & 13,00 & 13,00 & - \\
\hline Xylopia aromatica & 14,00 & 12,00 & 16,00 & 13,00 & 14,00 & 15,00 & 2,83 \\
\hline Rapanea umbellata & - & - & - & - & - & - & - \\
\hline Outras & 8,67 & 5,00 & 20,00 & 5,00 & 7,00 & 9,75 & 4,98 \\
\hline
\end{tabular}


Tabela E1.5: CAP na área 5

\begin{tabular}{lccccccc}
\hline \multicolumn{7}{c}{ CAP - Circunferência à Altura do Peito (cm) } \\
\hline \multirow{2}{*}{ Vegetação } & Média & Mínimo & Máximo & 10 Quartil & Mediana & 30 Quartil & DP \\
\cline { 2 - 8 } & - & - & - & - & - & - & - \\
Peltophorum dubium & - & - & - & - & - & - & - \\
Achinus terebentifolius & - & - & - & - & - & - & - \\
Lafoensia pacari & - & - & - & - & - & - & - \\
Psidium guajaba & - & - & - & - & - & - & - \\
Inga edulis & - & - & - & - & - & - & - \\
Enterolobium & - & - & - & - & & & \\
contortisiliquum & - & - & - & - & - & - & - \\
Psudobombax manguba & - & - & - & - & - & - & - \\
Jacaranda micrantha & - & - & - & - & - & - & - \\
Croton floribundus & - & - & - & - & - & - & - \\
Hymenaea stigonocarpa & - & - & - & - & - & - & - \\
Inga uruguensis & - & - & - & - & - & - & - \\
Pterogiyne nitens & - & - & - & - & - & - & - \\
Luehea paniculata & - & - & - & - & - & - & - \\
Tabebuia cassineoides & - & - & - & - & - & - & - \\
Nectandra cuspidata & 12,44 & 7,00 & 18,00 & 9,00 & 13,50 & 15,00 & 3,36 \\
Copaifera langsdorffii & 15,91 & 6,00 & 36,00 & 8,00 & 14,00 & 23,75 & 8,95 \\
Mollinedia schottiana & 7,67 & 5,00 & 20,00 & 5,00 & 7,00 & 9,00 & 3,47 \\
Tapirira guianensis & 32,10 & 14,00 & 56,00 & 20,00 & 28,00 & 46,75 & 13,89 \\
Xylopia aromatica & 23,31 & 16,00 & 37,00 & 18,50 & 21,00 & 26,50 & 6,74 \\
Rapanea umbellata & 14,57 & 8,00 & 27,00 & 9,75 & 13,00 & 20,00 & 5,68 \\
Outras & 15,69 & 5,00 & 66,00 & 9,00 & 12,00 & 18,00 & 11,87 \\
\hline
\end{tabular}


Tabela E2.1: Altura na área 1

\begin{tabular}{lccccccc}
\hline \multicolumn{7}{c}{ Vegetação } & \multicolumn{7}{c}{ Altura (m) } \\
\cline { 2 - 8 } & Média & Mínimo & Máximo & 10 Quartil & Mediana & 30 Quartil & DP \\
\hline Peltophorum dubium & 5,60 & 3,00 & 8,00 & 4,35 & 5,40 & 7,25 & 1,78 \\
Schinus terebentifolius & 5,08 & 3,30 & 6,50 & 4,15 & 5,30 & 5,90 & 1,15 \\
Acacia polyphilla & 7,77 & 5,00 & 11,50 & 6,50 & 7,50 & 8,63 & 1,73 \\
Lafoensia pacari & 5,33 & 4,50 & 6,00 & 4,63 & 5,40 & 5,95 & 0,70 \\
Psidium guajaba & 4,43 & 2,70 & 8,00 & 3,05 & 3,50 & 6,13 & 1,91 \\
Inga edulis & 4,63 & 2,40 & 7,50 & 2,40 & 4,00 & 7,50 & 2,61 \\
Enterolobium & & - & - & - & & & \\
contortisiliquum & - & - & - & 4,88 & 7,00 & 7,88 & 1,94 \\
Psudobombax manguba & 6,47 & 3,00 & 9,00 & 4,00 & \\
Jacaranda micrantha & 4,89 & 2,10 & 7,50 & 3,28 & 5,25 & 6,25 & 1,75 \\
Croton floribundus & 6,15 & 2,30 & 10,50 & 3,00 & 6,75 & 8,63 & 2,99 \\
Hymenaea stigonocarpa & 5,98 & 5,00 & 7,00 & 5,13 & 5,95 & 6,85 & 0,90 \\
Inga uruguensis & 5,70 & 2,10 & 9,00 & 2,10 & 6,00 & 9,00 & 3,46 \\
Pterogiyne nitens & 7,75 & 6,50 & 9,00 & 7,13 & 7,75 & 8,38 & 1,77 \\
Luehea paniculata & 3,50 & 3,50 & 3,50 & 3,50 & 3,50 & 3,50 & - \\
Tabebuia cassineoides & 4,50 & 2,50 & 6,50 & 2,50 & 4,50 & 6,50 & 2,00 \\
Nectandra cuspidata & - & - & - & - & - & - & - \\
Copaifera langsdorffii & - & - & - & - & - & - & - \\
Mollinedia schottiana & - & - & - & - & - & - & - \\
Tapirira guianensis & - & - & - & - & - & - & - \\
Xylopia aromatica & - & - & - & - & - & - & - \\
Rapanea umbellata & - & - & - & - & - & - & - \\
Outras & 5,55 & 2,00 & 11,00 & 3,65 & 5,00 & 7,00 & 2,36 \\
\hline
\end{tabular}


Tabela E2.2: Altura na área 2

\begin{tabular}{lccccccc}
\hline \multicolumn{7}{c}{ Vegetação } & \multicolumn{7}{c}{ Altura $(\mathbf{m})$} \\
\cline { 2 - 8 } & Média & Mínimo & Máximo & 10 Quartil & Mediana & 30 Quartil & DP \\
\hline Peltophorum dubium & 3,87 & 2,80 & 5,30 & 2,95 & 3,45 & 5,23 & 1,10 \\
Schinus terebentifolius & 2,94 & 1,80 & 4,30 & 2,20 & 3,00 & 3,90 & 0,91 \\
Acacia polyphilla & 2,76 & 1,40 & 4,50 & 2,10 & 2,50 & 3,10 & 0,83 \\
Lafoensia pacari & 3,14 & 1,80 & 5,50 & 2,00 & 2,90 & 4,10 & 1,29 \\
Psidium guajaba & 3,66 & 2,90 & 4,10 & 3,20 & 3,80 & 4,05 & 0,48 \\
Inga edulis & 3,17 & 3,00 & 3,50 & 3,00 & 3,00 & 3,50 & 0,29 \\
Enterolobium & & & & & & & \\
contortisiliquum & 4,00 & 2,80 & 5,00 & 3,48 & 4,10 & 4,43 & 0,68 \\
Psudobombax manguba & 3,15 & 1,60 & 6,50 & 1,95 & 3,05 & 3,85 & 1,43 \\
Jacaranda micrantha & 2,00 & 2,00 & 2,00 & 2,00 & 2,00 & 2,00 & - \\
Croton floribundus & 3,86 & 1,30 & 7,00 & 2,85 & 3,70 & 5,00 & 1,66 \\
Hymenaea stigonocarpa & 1,90 & 1,70 & 2,20 & 1,70 & 1,80 & 2,20 & 0,26 \\
Inga uruguensis & 3,93 & 2,20 & 7,00 & 2,28 & 3,25 & 6,25 & 2,20 \\
Pterogiyne nitens & - & - & - & - & - & - & - \\
Luehea paniculata & 2,60 & 2,00 & 3,00 & 2,00 & 2,80 & 3,00 & 0,53 \\
Tabebuia cassineoides & 1,50 & 1,50 & 1,50 & 1,50 & 1,50 & 1,50 & - \\
Nectandra cuspidata & - & - & - & - & - & - & - \\
Copaifera langsdorffii & - & - & - & - & - & - & - \\
Mollinedia schottiana & - & - & - & - & - & - & - \\
Tapirira guianensis & - & - & - & - & - & - & - \\
Xylopia aromatica & - & - & - & - & - & - & - \\
Rapanea umbellata & - & - & - & - & - & - & - \\
Outras & 3,65 & 1,00 & 8,50 & 2,10 & 3,70 & 4,75 & 1,92 \\
\hline
\end{tabular}


Tabela E2.3: Altura na área 3

\begin{tabular}{|c|c|c|c|c|c|c|c|}
\hline \multicolumn{8}{|c|}{ Altura (m) } \\
\hline \multirow{2}{*}{ Vegetação } & \multicolumn{7}{|c|}{ Área 3 (8 anos) } \\
\hline & Média & Mínimo & Máximo & 1o Quartil & Mediana & 3o Quartil & $\mathrm{DP}$ \\
\hline Peltophorum dubium & 6,12 & 3,50 & 10,00 & 4,55 & 6,15 & 7,45 & 1,72 \\
\hline Schinus terebentifolius & 4,98 & 3,50 & 7,50 & 4,30 & 4,80 & 5,80 & 1,04 \\
\hline Acacia polyphilla & 7,96 & 6,20 & 10,00 & 6,63 & 7,50 & 9,75 & 1,51 \\
\hline Lafoensia pacari & 4,58 & 2,80 & 6,50 & 3,85 & 4,30 & 5,40 & 0,99 \\
\hline Psidium guajaba & 4,04 & 3,10 & 5,20 & 3,70 & 4,00 & 4,30 & 0,63 \\
\hline $\begin{array}{l}\text { Inga edulis } \\
\text { Enterolobium }\end{array}$ & 5,75 & 2,50 & 8,30 & 5,00 & 5,50 & 7,00 & 1,48 \\
\hline contortisiliquum & 6,45 & 3,70 & 8,00 & 5,98 & 6,60 & 7,25 & 1,29 \\
\hline Psudobombax manguba & 4,13 & 3,40 & 5,00 & 3,40 & 4,00 & 5,00 & 0,81 \\
\hline Jacaranda micrantha & 5,50 & 5,50 & 5,50 & 5,50 & 5,50 & 5,50 & - \\
\hline Croton floribundus & 5,00 & 5,00 & 5,00 & 5,00 & 5,00 & 5,00 & - \\
\hline Hymenaea stigonocarpa & 4,05 & 2,40 & 7,00 & 3,25 & 3,90 & 4,45 & 1,36 \\
\hline Inga uruguensis & 8,33 & 8,00 & 8,50 & 8,00 & 8,50 & 8,50 & 0,29 \\
\hline Pterogiyne nitens & 4,25 & 2,50 & 6,00 & 3,48 & 4,35 & 4,88 & 1,13 \\
\hline Luehea paniculata & 3,60 & 2,80 & 4,40 & 3,20 & 3,60 & 4,00 & 1,13 \\
\hline Tabebuia cassineoides & 2,30 & 2,30 & 2,30 & 2,30 & 2,30 & 2,30 & - \\
\hline Nectandra cuspidata & - & - & - & - & - & - & - \\
\hline Copaifera langsdorffii & 4,55 & 2,60 & 6,50 & 3,58 & 4,55 & 5,53 & 2,76 \\
\hline Mollinedia schottiana & 2,80 & 2,80 & 2,80 & 2,80 & 2,80 & 2,80 & - \\
\hline Tapirira guianensis & - & - & - & - & - & - & - \\
\hline Xylopia aromatica & - & - & - & - & - & - & - \\
\hline Rapanea umbellata & - & - & - & - & - & - & - \\
\hline Outras & 5,12 & 2,40 & 11,00 & 3,50 & 4,80 & 6,20 & 1,90 \\
\hline
\end{tabular}


Tabela E2.4: Altura na área 4

\begin{tabular}{lccccccc}
\hline \multicolumn{7}{c}{ Vegetação } & \multicolumn{7}{c}{ Altura (m) } \\
\cline { 2 - 8 } & Média & Mínimo & Máximo & 10 Quartil & Mediana & 30 Quartil & DP \\
\hline Peltophorum dubium & 4,65 & 2,20 & 6,60 & 3,33 & 4,65 & 6,00 & 1,52 \\
Schinus terebentifolius & 3,88 & 2,00 & 6,50 & 2,93 & 3,70 & 4,50 & 1,20 \\
Acacia polyphilla & 4,22 & 2,30 & 7,20 & 3,15 & 3,50 & 5,75 & 1,53 \\
Lafoensia pacari & 2,96 & 2,30 & 3,80 & 2,48 & 2,90 & 3,55 & 0,54 \\
Psidium guajaba & 2,94 & 2,20 & 4,20 & 2,50 & 2,75 & 3,40 & 0,60 \\
Inga edulis & 4,90 & 3,50 & 6,00 & 3,75 & 5,05 & 5,90 & 1,13 \\
Enterolobium & & & & & & & \\
contortisiliquum & 5,29 & 2,50 & 7,00 & 4,30 & 5,70 & 6,50 & 1,59 \\
Psudobombax manguba & 2,90 & 2,90 & 2,90 & 2,90 & 2,90 & 2,90 & - \\
Jacaranda micrantha & 3,80 & 3,80 & 3,80 & 3,80 & 3,80 & 3,80 & - \\
Croton floribundus & - & - & - & - & - & - & - \\
Hymenaea stigonocarpa & - & - & - & - & - & - & - \\
Inga uruguensis & 2,68 & 1,60 & 5,00 & 1,80 & 2,20 & 3,80 & 1,35 \\
Pterogiyne nitens & 2,60 & 2,60 & 2,60 & 2,60 & 2,60 & 2,60 & - \\
Luehea paniculata & 2,67 & 2,40 & 3,00 & 2,40 & 2,60 & 3,00 & 0,31 \\
Tabebuia cassineoides & 2,50 & 1,40 & 3,20 & 1,40 & 2,90 & 3,20 & 0,96 \\
Nectandra cuspidata & - & - & - & - & - & - & - \\
Copaifera langsdorffii & - & - & - & - & - & - & - \\
Mollinedia schottiana & - & - & - & - & - & - & - \\
Tapirira guianensis & 4,00 & 4,00 & 4,00 & 4,00 & 4,00 & 4,00 & - \\
Xylopia aromatica & 4,10 & 3,80 & 4,40 & 3,95 & 4,10 & 4,25 & 0,42 \\
Rapanea umbellata & - & - & - & - & - & - & - \\
Outras & 3,03 & 2,00 & 5,00 & 2,43 & 2,95 & 3,35 & 0,87 \\
\hline
\end{tabular}


Tabela E2.5: Altura na área 5

\begin{tabular}{lccccccc}
\hline \multicolumn{7}{c}{ Vegetação } & \multicolumn{7}{c}{ Altura (m) } \\
\cline { 2 - 8 } & Média & Mínimo & Máximo & 10 Quartil & Mediana & 30 Quartil & DP \\
\hline Peltophorum dubium & - & - & - & - & - & - & - \\
Schinus terebentifolius & - & - & - & - & - & - & - \\
Acacia polyphilla & - & - & - & - & - & - & - \\
Lafoensia pacari & - & - & - & - & - & - & - \\
Psidium guajaba & - & - & - & - & - & - & - \\
Inga edulis & - & - & - & - & - & - & - \\
Enterolobium & & & & & & & \\
contortisiliquum & - & - & - & - & - & - & - \\
Psudobombax manguba & - & - & - & - & - & - & - \\
Jacaranda micrantha & - & - & - & - & - & - & - \\
Croton floribundus & - & - & - & - & - & - & - \\
Hymenaea stigonocarpa & - & - & - & - & - & - & - \\
Inga uruguensis & - & - & - & - & - & - & - \\
Pterogiyne nitens & - & - & - & - & - & - & - \\
Luehea paniculata & - & - & - & - & - & - & - \\
Tabebuia cassineoides & - & - & - & - & - & - & - \\
Nectandra cuspidata & 5,40 & 2,30 & 8,00 & 3,43 & 5,75 & 7,00 & 1,85 \\
Copaifera langsdorffii & 5,34 & 2,20 & 10,00 & 3,50 & 4,90 & 6,88 & 2,22 \\
Mollinedia schottiana & 4,19 & 2,00 & 6,50 & 2,80 & 4,00 & 5,25 & 1,44 \\
Tapirira guianensis & 7,56 & 4,00 & 10,00 & 6,13 & 8,00 & 9,00 & 1,62 \\
Xylopia aromatica & 6,57 & 4,00 & 10,00 & 5,50 & 6,50 & 7,50 & 1,59 \\
Rapanea umbellata & 5,67 & 3,00 & 9,00 & 4,25 & 5,75 & 7,00 & 1,77 \\
Outras & 5,22 & 2,00 & 11,00 & 3,58 & 5,00 & 6,00 & 2,01 \\
\hline
\end{tabular}


ANEXO A: CORRELAÇÃO ENTRE VARIÁVEIS DO SUBSTRATO 
Tabela A1: Correlação entre variáveis do substrato

\begin{tabular}{|c|c|c|c|c|c|c|c|c|c|c|c|c|c|}
\hline & Densidade & Porosidade & $\mathrm{pH}$ & MO & SB & СTC & Cálcio & Magnésio & Potássio & Fósforo & v & $\begin{array}{l}\text { Hidrogênio } \\
\text { + Alum }\end{array}$ & Alumínio \\
\hline $\begin{array}{c}\text { Densidade } \\
\text { p-valor }\end{array}$ & 1 & & & & & & & & & & & & \\
\hline Porosidade & $-0,983$ & 1 & & & & & & & & & & & \\
\hline p-valor & $<, 0001$ & & & & & & & & & & & & \\
\hline $\mathrm{pH}$ & 0,556 & $-0,513$ & 1 & & & & & & & & & & \\
\hline p-valor & $<, 0001$ & $<, 0001$ & & & & & & & & & & & \\
\hline MO & $-0,776$ & 0,759 & $-0,463$ & 1 & & & & & & & & & \\
\hline p-valor & $<, 0001$ & $<, 0001$ & $<, 0001$ & & & & & & & & & & \\
\hline SB & $-0,137$ & 0,156 & 0,344 & 0,352 & 1 & & & & & & & & \\
\hline p-valor & 0,163 & 0,112 & 0,000 & 0,000 & & & & & & & & & \\
\hline CTC & $-0,760$ & 0,722 & $-0,611$ & 0,910 & 0,206 & 1 & & & & & & & \\
\hline p-valor & $<, 0001$ & $<, 0001$ & $<, 0001$ & $<, 0001$ & 0,035 & & & & & & & & \\
\hline Cálcio & $-0,125$ & 0,147 & 0,362 & 0,345 & 0,994 & 0,193 & 1 & & & & & & \\
\hline p-valor & 0,204 & 0,135 & 0,000 & 0,000 & $<, 0001$ & 0,049 & & & & & & & \\
\hline Magnésio & $-0,110$ & 0,126 & 0,338 & 0,303 & 0,980 & 0,175 & 0,953 & 1 & & & & & \\
\hline p-valor & 0,265 & 0,201 & 0,000 & 0,002 & $<, 0001$ & 0,073 & $<, 0001$ & & & & & & \\
\hline Potássio & $-0,524$ & 0,509 & $-0,080$ & 0,758 & 0,733 & 0,596 & 0,733 & 0,665 & 1 & & & & \\
\hline p-valor & $<, 0001$ & $<, 0001$ & 0,419 & $<, 0001$ & $<, 0001$ & $<, 0001$ & $<, 0001$ & $<, 0001$ & & & & & \\
\hline Fósforo & $-0,476$ & 0,446 & $-0,195$ & 0,662 & 0,570 & 0,591 & 0,565 & 0,528 & 0,744 & 1 & & & \\
\hline p-valor & $<, 0001$ & $<, 0001$ & 0,046 & $<, 0001$ & $<, 0001$ & $<, 0001$ & $<, 0001$ & $<, 0001$ & $<, 0001$ & & & & \\
\hline v & 0,362 & $-0,323$ & 0,819 & $-0,191$ & 0,728 & $-0,367$ & 0,751 & 0,693 & 0,317 & 0,197 & 1 & & \\
\hline p-valor & 0,000 & 0,001 & $<, 0001$ & 0,051 & $<, 0001$ & 0,000 & $<, 0001$ & $<, 0001$ & 0,001 & 0,045 & & & \\
\hline Hidro + Alum & $-0,743$ & 0,699 & $-0,708$ & 0,844 & $-0,034$ & 0,971 & $-0,046$ & $-0,061$ & 0,430 & 0,464 & $-0,553$ & 1 & \\
\hline p-valor & $<, 0001$ & $<, 0001$ & $<, 0001$ & $<, 0001$ & 0,729 & $<, 0001$ & 0,641 & 0,538 & $<, 0001$ & $<, 0001$ & $<, 0001$ & & \\
\hline Aluminio & $-0,573$ & 0,547 & $-0,931$ & 0,518 & $-0,365$ & 0,676 & $-0,384$ & $-0,358$ & 0,056 & 0,135 & $-0,828$ & 0,780 & 1 \\
\hline p-valor & $<, 0001$ & $<, 0001$ & $<, 0001$ & $<, 0001$ & 0,000 & $<, 0001$ & $<, 0001$ & 0,000 & 0,571 & 0,171 & $<, 0001$ & $<, 0001$ & \\
\hline
\end{tabular}

Fonte: Tanaka et al. (2009) 